UNIVERSIDADE DE SÃO PAULO

FABIO SALVATTI

\title{
O PRANK COMO OPÇÃO PERFORMATIVA PARA A REDE DE ATIVISMO POLÍTICO CONTEMPORÂNEO
}

SÃo PAULO

2010 
FABIO SALVATTI

\section{O PRANK COMO OPÇÃO PERFORMATIVA PARA A REDE DE ATIVISMO POLÍTICO CONTEMPORÂNEO}

Tese apresentada ao Programa de Pós-Graduação em Artes Cênicas, Área de Concentração Teoria e Prática do Teatro, Linha de Pesquisa Texto e Cena, da Escola de Comunicação e Artes da Universidade de São Paulo, como exigência para obtenção do título de Doutor em Artes Cênicas, sob a orientação do Professor Dr. Luiz Fernando Ramos.

\section{SÃO PAULO}


Nota de Copyleft: a reprodução parcial ou total desta obra e sua difusão de forma eletrônica é consentida para propósitos não comerciais, desde que esta nota seja preservada. 
A Odete Nadolny Klodzinski (in memoriam).

A теи pai. 


\section{AGRADECIMENTOS}

\section{À CAPES,}

Ao Programa de Pós-Graduação em Artes Cênicas da ECA-USP, seu corpo docente e discente,

A meu orientador, prof. Luiz Fernando Ramos,

Ao prof. Paul Heritage, e à equipe da Queen Mary University of London, em especial a Sra. Rachel Sanger, e aos professores Michael McKinnie e Nicholas Ridout.

A minha mãe, Silvia Salvatti, meu pai, Antonio Aldo Salvatti e minha irmã, Danuta Salvatti,

A Larissa Nowak,

Aos professores Margie Rauen, Nini Beltrame, Renato Ferracini, José Correa Leite, Silvia Fernandes, Sérgio de Carvalho e Fernando Villar.

Aos meus amigos, em especial a André Moreira, Carolina Fauquemont, Caroline Nocetti, Clóvis Inocêncio, Fabio Kinas, Fabro Steibel, Gael Le Cornec, Guto Santana, Humberto Gomes, Isaias Masiero Filho, Juliana Serra, Juliano Mezzomo, Lucianna Raitani, Luciano Lacerda, Maíra Chasseraux, Maitê Chasseraux, Marcelo Wasem, Marie Ange Bordas, Marianne Tezza, Marina Willer, Menino Josué, Mica Schiocchet, Paulo Emílio Ferreira, Rodrigo Garcez e Silvia Ciccarino,

Aos ativistas e coletivos que contribuíram com esta pesquisa, em especial a Lottie Child, Michael (Unimondal Monad), Davux (Les Tanneries), Olya, Tom, Vlanto, Agnés, Marie, Maxigas, Luke, Milla,

Ao Coletivo Epidemia,

A Brian Holmes, Roberto Bui e Stewart Home,

A Kiwi Companhia de Teatro (Fernando Kinas, Fernanda Azevedo, Márcia Bechara, Demian Garcia, Marísia Brüning, Lori Santos, Simone Spoladore, Chiris Gomes e Gavin Adams). 
Se não pudermos rir,

o mundo que faremos será quadrado e não seremos capazes de fazê-lo girar.

Subcomandante Marcos 


\section{SUMÁRIO}

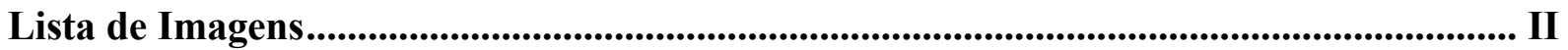

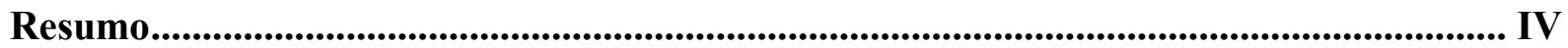

Abstract.......................................................................................................................................................

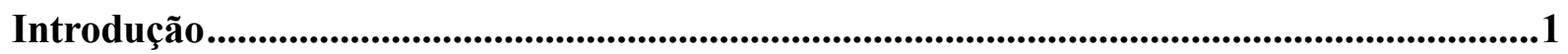

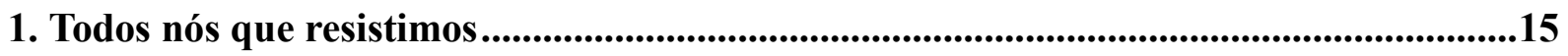

2. Entre o político e o estético .........................................................................................................46

3. Cartografias da autonomia ............................................................................................................ 72

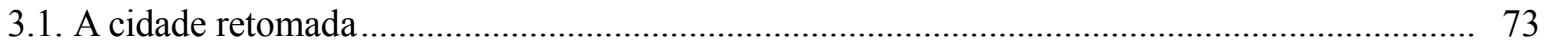

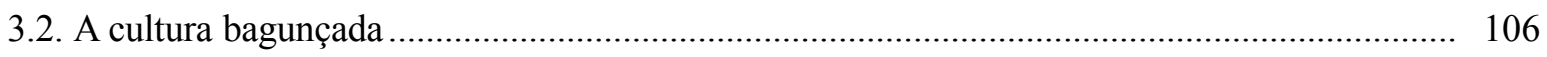

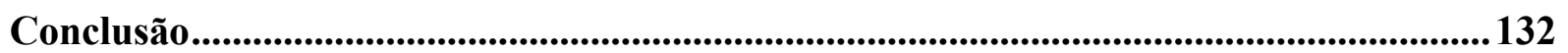

Referências bibliográficas........................................................................................ 137

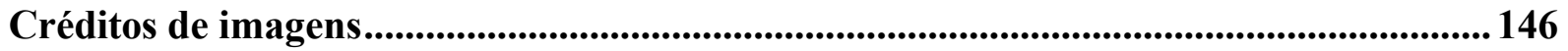

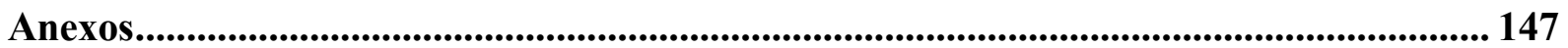

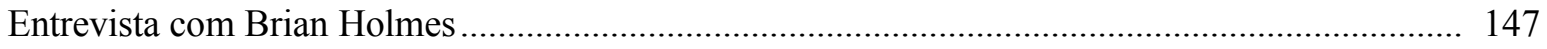

Extratos do Manual Prático de Delinquência Juvenil ........................................................................... 157 


\section{LISTA DE IMAGENS}

Figura 1: Placa de "Pare" adulterada, em Curitiba.

Figura 2: Esquerda: Estratégia de construção de tripés, utilizada pelo Reclaim the Streets para bloquear o trânsito, Streatham, Reino Unido. Direita: Carnaval contra o capital, 18 de junho de 1999, Londres, Reino Unido 30

Figura 3: Esquerda: Black bloc em ação. Direita: Detalhe de um integrante do Black bloc. 32

Figura 4: Esquerda: Tute Bianche em marcha, 10 de setembro de 1994, Milão, Itália. Direita: Integrante do Tute Bianche se protegendo das investidas dos carabinieri, julho de 2001, Gênova, Itália.

Figura 5: Esquerda: Subcomandante Marcos, abril de 2006, sudeste do México. Direita: Rosto fictício de Luther Blissett, composto por fragmentos de imagens de outras faces.

Figura 6: Esquerda: Street trainers em Camberwell, julho de 2009, Londres, Reino Unido. Direita: Street trainers em Peckham, setembro de 2008, Londres, Reino Unido. 75

Figura 7: Esquerda: Street trainers em Curitiba (eu sou o último da direita), novembro de 2009, Curitiba. Direita: Eu me esforçando no limbo dancing do street training de Peckham, setembro de 2008, Londres, Reino Unido.

Figura 8: Esquerda: “A beleza está nas ruas”, cartaz de maio de 1968. Direita: Manifestações em Paris, maio de 1968.

Figura 9: Esquerda: "Tortura" do candidato a prefeito Boris Johson na festa Mayday dos Space Hijackers, 01 de maio de 2008, Londres, Reino Unido. Direita: Dança do poste do Mayday. 86

Figura 10: Esquerda: Loolie, dos Artists Anonymous, participando do leilão do tanque de guerra promovido pelos Space Hijackers, 11 de setembro de 2007, Londres, Reino Unido. Direita: Space Hijackers comemorando o sucesso de sua empreitada.

Figura 11: Esquerda: Flash mob \#2, na loja Macy's, 17 de junho de 2003, Nova York, EUA. Direita: Flash mob \#6, na loja Toys R Us, 08 de agosto de 2003, Nova York, EUA.

Figura 12: Stencil de Banksy a partir da foto do jornalista Nic Ut e de imagens de divulgação da Disney e do McDonalds.

Figura 13: Esquerda: Stencil de Banksy a partir do retrato da Rainha Vitória. Direita: "Pintura vandalizada" de Banksy, uma arte rupestre da era consumista, exposta no British Museum, Londres, Reino Unido.

Figura 14: Esquerda: Anúncio anti-McDonalds da Billboard Liberation Front, 30 de maio de 2005, San Francisco, EUA. Direita: Ronald McDonald sendo preso por policiais.

Figura 15: Esquerda: Anúncio paródia da Absolut Vodka. Direita: Anúncio paródia da Nike. 118 
Figura 16: Esquerda: Hank Hardy Unruh, falso representante da OMC, com seu falo dourado, agosto de 2001, Tampere, Finlândia. Direita:Yes Men em seu traje anti-catástrofes, Survivaball, outubro de 2005 


\section{RESUMO}

A rede de ativismo político contemporâneo tem orientado suas ações em direção a um campo híbrido que desconsidera fronteiras entre ativismo e arte . Dentre a variedade de práticas desta rede, o prank é um exemplo da desconsideração destas fronteiras. Um prank é um golpe, uma ruptura jocosa da ordem, da hierarquia, da autoridade. Como prática, o prank é abordado ao longo deste trabalho como uma opção performativa para o ativismo político, uma vez que reúne características lúdicas, críticas, vivenciais e multiplicadoras.

Os ativistas que adotam o prank como opção se relacionam com a história recente da rede de ativismo político contemporâneo, que resiste a um novo modelo de organização do capitalismo. De 1994 a 2003, esta rede estabeleceu um panorama de macroações (em especial, os Dias de Ação Global) festivas e insurgentes. O ativismo difuso, diluído no cotidiano com ações em menor escala, também tem adotado a mesma orientação irreverente. Isto é especialmente verificável na reivindicação pelo espaço, entendido de maneira ampla, tanto como espaço urbano erodido pela invasão do capital, quanto como espaço da comunicação, da ideologia e das trocas simbólicas.

As modalidades de pranks adotadas neste contexto são examinadas a partir de categorias como a teatralidade e a performatividade, conforme entendidas por Josette Féral. Estas ferramentas contribuem na conclusão de que na performance atravessada pelo prank não existem mediadores, ela é autônoma, orientada pelo princípio político do "faça você mesmo".

Palavras-chave: prank, ativismo, performance, rede, antiglobalização. 


\begin{abstract}
The current network of political activism has pursued a hybrid field, ignoring the borders between activism and art. Amongst the various genres of this network, the prank illustrates how such borders are blurred. A prank is a blow, a whimsical breaking of order, of hierarchy, and of authority. This thesis addresses prank as a practice, a performance option for political activism, provided that it merges experiences of play, criticism, liveness and dissemination.

Activists who have chosen the prank are related with a recent history of the contemporary network of political mobilization, which resists to a new capitalist pattern of organization. From 1994 through 2003, this network established a scenario of celebrations and radical macro-actions (particularly the Days of Global Action). The spread out activism that is blended in daily life also features a similar invasive attitude. This is especially true in their claims for space, broadly understood both as urban space that has been contaminated by the invasion of capital, and as a space of communication, ideology and symbolic exchange. I have examined the various prank genres within this context on the basis of categories such as theatricality and performativity, according to Josette Féral's stance. These considerations have led me to the conclusion that there are no mediators when prank merges with performance, since it is autonomous and draws on the "do it yourself" political principle.
\end{abstract}

Keywords: prank, activism, performance, network, antiglobalization 


\section{INTRODUÇÃO}

Não existe revolução quando não se pode dançar.

Emma Goldman

Uma placa hexagonal na esquina de uma grande cidade. Ao contrário do que se poderia esperar, ela não orienta os motoristas com seu "PARE" no imperativo. Isto porque uma intervenção realizada com um spray de tinta tão vermelha quanto a da placa apagou o "P" e o "E" da palavra. Na esquina ficou, então, um outro imperativo: "AR". Esta pequena intervenção jocosa sobre a placa conseguiu criar uma sensação de irreverência pela simples supressão de duas letras. Com isso, subverteu o significado original da sinalização e imprimiu uma outra camada significante, poeticamente oposta à cultura do automóvel que a placa deveria integrar. É como se, de repente, a placa sugerisse ao motorista que ele abandone seu automóvel emissor de monóxido de carbono para que ainda possamos ter um planeta com ar respirável.

Neste exemplo mínimo, a ação interventora parece ser uma semente de uma atitude complexa, que combina humor e crítica. Algo além da legalidade e também além do vandalismo. Diferente dos grandes discursos ideológicos que permearam a história do século XX, mas também diferente da afasia apolítica que parece predominar na sociedade contemporânea.

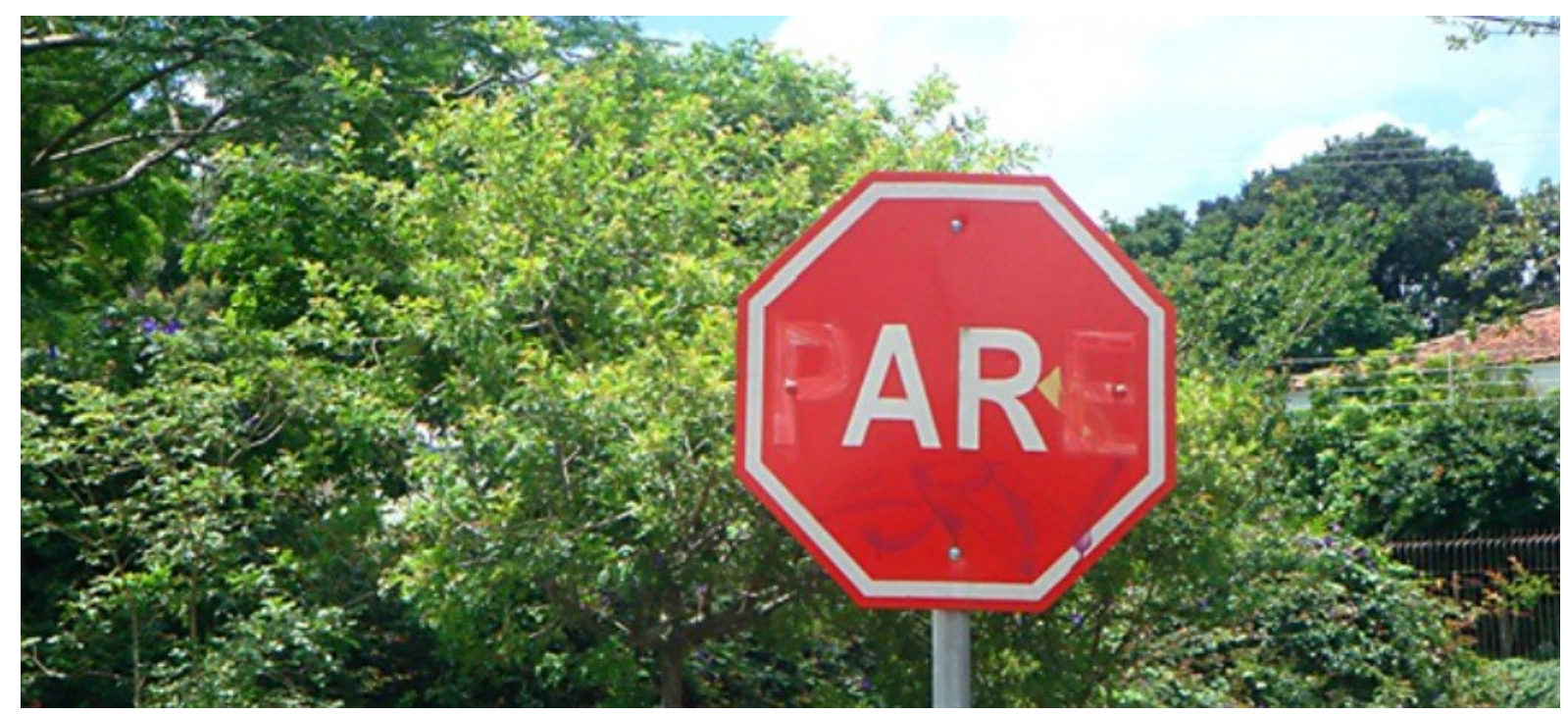

Figura 1: Placa de "Pare" adulterada, em Curitiba. 
Para abordar esta atitude complexa, bem como exemplos mais germinados da mesma semente e aproximá-los da produção artística e política contemporânea, gostaria de propor o conceito de prank. Um prank é um golpe, um trote, um chiste, ainda que sua tradução se perca entre estas diferentes palavras ${ }^{1}$. Se quisermos, prank pode ser algo como "pregar uma peça", uma travessura, uma sabotagem. Pressupõe irreverência, uma certa molecagem desautorizadora.

O spray sobre a placa sabota nossas expectativas normais sobre ela. É, por isso, um exemplo elementar, minimal, da atitude prankster. Mas, decididamente, o prank não se restringe a intervenções gráficas em placas ou muros das grandes cidades. É uma prática disseminada em diversas esferas de nossa experiência social.

A publicação estadunidense RE/Search ${ }^{2}$ dedicou duas edições (uma de 1987 e outra de 2006) exclusivamente a entrevistas com pranksters, isto é, artistas e ativistas dedicados ao prank. Na introdução do primeiro destes números, a editora, V. Vale, apresenta a prática da seguinte maneira:

Um prank conota diversão, risada, chiste, sátira, pilhéria, fazer alguém de bobo. Assim os pranks camuflam o ferrão de denotações mais profundas e críticas, com o seu desafio direto às rotinas verbais e comportamentais, a sabotagem da autoridade soberana das palavras, linguagem, imagens e convenções sociais em geral. (...) Grandes pranks criam experiências sinestésicas que são sem dúvida excitantes, originais e reverberantes, assim como criativas, metafóricas, poéticas e artísticas. (...) Colocando em questão conceitos inerentemente dúbios como "realidade", "confiança", "crença", "obediência" e "contrato social", os pranks ocasionalmente são bem-sucedidos em implantar uma profunda e duradoura desconfiança sobre as convenções sociais e as instituições. ${ }^{3}$

É, sem dúvida, uma visão "tridimensionalizada" da questão: Vale detecta e apresenta denotações e consequências que não estariam evidentes a quem se esforçasse ou estivesse condicionado a enxergar nos pranks apenas uma bobagem juvenil. Mas

Exatamente pela pluralidade de possibilidades de tradução e pela ausência de um correspondente adequado em língua portuguesa é que mantenho ao longo deste trabalho o conceito no original em inglês. A etimologia do termo é incerta. Em inglês arcaico, pode significar "vestir um disfarce". As palavras que guardam semelhança, a holandesa pronken e a alemã prunken significam "exibir-se, ostentar".

2 RE/Search é uma publicação (e também uma editora) originária da revista punk "Search and Destroy", ativa durante 1977 e 1979. Entre 1980 e 2001 foram publicados 16 números da RE/Search, a maioria com entrevistas de artistas e ativistas contra-culturais. Além desses volumes, foram publicadas edições especiais, como é o caso da Pranks \#2, livros e textos de autores como J. G. Ballard e Charles Willeford.

3 VALE, V. e JUNO, A. "Introduction" in RE/Search \#11: Pranks, 1986, p. 04. A livre-tradução é minha, assim como será a de todos os outros textos com título em língua estrangeira citados neste trabalho, salvo indicações. 
também não seria verdadeiro pressupor que a prática do prank seja automaticamente engajada em objetivos políticos.

Há uma tradição em programas televisivos (ou em quadros dentro de programas televisivos) que no Brasil é conhecida como "pegadinha". Uma câmera oculta flagra uma determinada situação armada para enganar uma pessoa. Esta pessoa pode ser um transeunte, um convidado do programa, ou um espectador. $\mathrm{O}$ truque consiste em compartilhar a armadilha com todos os envolvidos (telespectadores inclusive) mas não, obviamente, com a pessoa-alvo. O enredo-base da "pegadinha" geralmente apresenta uma situação verossímil (uma entrevista de emprego, uma compra no supermercado, um pedido de informação na rua) e evolui para uma consequência imprevista e ridicularizadora.

Vimos surgir, nos últimos dez anos, tanto na televisão quanto na internet, gravações de eventos cotidianos em que pequenos golpes são aplicados ou situações absolutamente nonsense são vividas por pura diversão. Os exemplos são vários, mas gostaria de mencionar apenas três como amostragem de um fenômeno mais amplo. Entre 2000 e 2002 foi ao ar na MTV "Jackass", um programa em que jovens realizavam experimentos escatológicos, violentos e perigosos numa quase paródia da atividade de dublês. O programa incluiu dentre suas esquetes uma luta de boxe em uma loja de departamento, teste de equipamento de choque nos testículos dos membros da equipe, corrida com carrinhos de supermercado e outras peripécias. "Jackass" teve uma audiência numerosa, e virou símbolo do riso a qualquer custo. Uma espécie de sucessor de "Jackass" na MTV é "Pranked", atualmente no ar. Com o mesmo tipo de humor de gosto duvidoso, consiste em uma compilação de vídeos caseiros de pessoas armando e sofrendo as consequências de pranks (por exemplo, um jovem que resolve depilar com fita adesiva a sobrancelha de um colega que está dormindo).

A facilidade e o barateamento de captação, edição e divulgação de imagens digitais fizeram com que a internet fosse invadida com vídeos das mais variadas naturezas. Com o lema "fazendo qualquer coisa você pode se tornar qualquer um" o 
francês Rémi Gaillard conseguiu que seus vídeos de pranks fossem assistidos por milhões de pessoas. Ele chamou a atenção quando infiltrou-se na comemoração do título da Taça da França de futebol em 2002, vencida pelo Lorient Futebol Clube. Disfarçado como jogador, recebeu os cumprimentos do então presidente Jacques Chirac e ergueu, junto com os atletas, a taça do campeonato. Outra infiltração foi em um concurso de Mister Universo, tradicional título de fisiculturismo. Gaillard, com seu corpo franzino e desprovido de bronzeado, chegou a subir no palco com os competidores, mas foi retirado por seguranças. Além destas imposturas, ele realiza outros tipos de ataques. Vestido de Pac-Man, entrou em um supermercado seguido por colegas vestidos de fantasmas, como no clássico jogo do videogame Atari. Também distribuiu alvos autocolantes pela cidade de Paris, e posteriormente tentou acertá-los chutando uma bola de futebol ${ }^{4}$. A popularidade de Rémi Gaillard levou, por exemplo, o programa dominical "Fantástico", da Rede Globo, a exibir um quadro com os seus pranks.

Claramente, tanto as "pegadinhas", quanto as ações de "Jackass", "Pranked" e de Rémi Gaillard, bem como de tantos outros exemplos possíveis, podem ser agrupados sob a denominação prank, mas não estou tão certo de que eles instaurem a "profunda e duradoura desconfiança sobre as convenções sociais e as instituições" de que fala Vale. Às vezes a fronteira entre estes pranks, apresentados como entretenimento nos programas televisivos, e aqueles a que eu pretendo me dedicar neste trabalho, é subjetiva, tênue ou inexistente. Creio que Vale não pretende nenhuma distinção valorativa, ela está preocupada com a atitude prankster. Sem dúvida esta atitude, bem como quase qualquer outra atitude que se pretenda transgressora, pode ser recuperada pelo status quo e transformada em mercadoria ou produto da indústria cultural.

No entanto, para fins de recorte do objeto de pesquisa, dedico-me aos pranks cuja motivação seja de ativismo político. Isto não significa, absolutamente, que os pranks aqui analisados sejam desprovidos de seu caráter lúdico (para quem os propõe

Estes e outros vídeos estão disponíveis em http://www.nimportequi.com 
e, eventualmente, para seus "alvos"), mas sim que eles comungam uma verve e um objetivo insurgente. Estes pranks visam, como presas, a grandes corporações capitalistas, reuniões de instituições supranacionais, conglomerados financeiros. Mas também, em um microcosmo, pretendem atacar as pequenas barreiras cotidianas que condicionam nossas experiências de relacionamento, de comportamento, de consumo. Enfim, abordo pranks que tenham como alvo preferencial o modo de produção capitalista em sua fase atual e outras estruturas de poder que estão direta ou indiretamente ligadas a ele, como o patriarcado, a heteronormatividade, o teísmo, o especismo, o racismo, o consumismo predatório, etc.

A pesquisa que desenvolvo neste trabalho pretende ressaltar os aspectos performativos dos pranks para que eles possam operar sobre a dinâmica de poder, subvertendo estruturas convencionais e, ainda assim, manterem-se como ações criativas e lúdicas de crítica social. Investigando a interpenetração que os pranks políticos realizam nas práticas performativas, busco perceber as contribuições que eles oferecem com o campo híbrido que instauram anulando fronteiras entre ativismo e arte. A hipótese que levanto é a de que os pranks constituem uma prática de performance crítica, e que sua adoção por parte da rede de ativismo político contemporâneo se dá por seu potencial lúdico, performativo e multiplicador.

Esta pesquisa é uma decorrência das minhas atividades pessoais como artista, ativista e pesquisador. Não concebo estas atividades de maneira isolada, e é da articulação entre elas que os caminhos deste trabalho foram trilhados. Durante meu processo de pesquisa de mestrado, que culminou na dissertação que defendi em 2004 junto ao Programa de Pós-Graduação em Teatro do Centro de Artes da Universidade do Estado de Santa Catarina, intitulada "A Plagiocombinação como Estratégia Dramatúrgica na Cibercultura", pude conceber o embrião da presente tese. Na época, a partir da enunciação da "estética do plágio" e da "plagiocombinação" pelo músico Tom Zé no encarte de seu CD Com Defeito de Fabricação, investiguei essa estratégia cada vez mais comum na arte contemporânea: a de articular fragmentos culturais preexistentes, rarefazendo o conceito de autoria nas obras de arte. Por consequência, 
eu pretendia problematizar o papel da propriedade privada do conhecimento, representada na figura dos direitos de autor. Durante a pesquisa me deparei com grupos de ativistas que tinham uma plataforma bem mais ampla do que a mera crítica ao copyright. Eles propunham uma sistemática luta contra o capital transnacional das grandes corporações e contra o processo de globalização levado a cabo após a derrocada do socialismo soviético. Suas estratégias inusitadas, criativas e insurgentes, com ações coletivas, coordenadas, reuniam características de práticas artísticas, sem, no entanto, reivindicar esta qualidade, me chamaram a atenção. Tive a oportunidade, no final de 2002, de realizar uma entrevista com Roberto Bui ${ }^{5}$, um dos idealizadores do Projeto Luther Blissett, que descreveu a participação de seu coletivo na organização das manifestações contra o encontro de cúpula do G8 em Gênova, Itália, em 2001. Pude perceber que Bui e outros ativistas estavam orientados para além do que a experiência de uma criação artística de senso estrito poderia oferecer. Havia uma espécie de continuum entre seu exercício político e sua atividade artística, e uma indissociabilidade que desconsiderava qualquer fronteira entre estas esferas. A decorrência disso foi que as ações organizadas por eles nos protestos de Gênova eram fortemente performáticas. Reconheci ali um objeto de estudos que motivava meu interesse e curiosidade: um certo modo de exercer a contestação política que era crítico, contundente, e, ao mesmo tempo, festivo, debochado, provocador, divertido.

Paralelamente a isso, a minha atividade na Kiwi Companhia de Teatro, companhia da qual eu fiz parte entre 2001 e 2008, sempre solicitou de mim uma postura que transpassasse o "propriamente dito" teatral. Com denotada verve política, os trabalhos da Kiwi abordam diferentes autores teatrais e não teatrais, vários dos quais ligados à filosofia, sociologia e teoria política. Expoente disso foi Teatro/Mercadoria, "situação teatral" estreada em dezembro de 2006, no Rio de Janeiro, e cujo projeto foi fomentado pela Lei Municipal do Fomento ao Teatro para a Cidade de São Paulo, cumprindo temporada entre dezembro de 2007 e fevereiro de

SANT'ANNA, Antonio C. V. e SALVATTI, Fábio. "De Luther Blissett a Wu Ming”. Disponível em www.casthalia.com.br/casthaliamagazine/casthalia magazine4.htm 
2008. Durante a apresentação, eram enunciados textos de Marx, Guy Debord, Brecht, Adorno, Benjamin, etc, para compor diversos tableaux tratando da arte sob o domínio da forma-mercadoria ${ }^{6}$. O processo de trabalho, as parcerias com movimentos sociais decorrentes deste processo e as buscas de ruptura formal da cena teatral instituída foram combustível para minha pesquisa doutoral.

Também é preciso, dada a contribuição para este trabalho, relevar a minha participação como ativista no coletivo Epidemia, entre 2006 e 2007. O grupo surgiu da necessidade de uma ação política de oposição ao atual sistema de proteção da propriedade intelectual (tanto no modelo do direito autoral quanto no de patentes) que fosse alternativa às convencionais estruturas de representatividade (sindicatos, agremiações, partidos) e que também se diferenciasse da ação do terceiro setor (organizações não-governamentais). O coletivo pretendia uma desmercantilização da cultura e do conhecimento, em um amplo movimento pelo livre acesso ao saber. Estabelecer uma relação militante com um coletivo de ativistas como o Epidemia (formado por economistas, sociólogos, filósofos, advogados, jornalistas, artistas, professores, etc) foi fundamental para, em primeiro lugar, acompanhar a agenda e as metodologias de suas reivindicações. Em segundo lugar, a experiência me subsidiou também em discussão e bibliografia política. Em terceiro lugar, foi importante para formar uma rede de contatos com outros atores sociais manifestantes.

Esta pesquisa foi enormemente beneficiada pela possibilidade de desenvolvimento de um estágio de pesquisa no Reino Unido, na Queen Mary, University of London, entre março e dezembro de 2008, sob orientação do professor Paul Heritage ${ }^{7}$. Ele desenvolve, há nove anos, trabalhos de intersecção entre ativismo e teatro como coordenador do People's Palace Project, instituição com sede no Rio de Janeiro e em Londres. Os principais trabalhos realizados pelo PPP envolvem direitos humanos, população carcerária e portadores de HIV. Paul Heritage já foi pesquisador visitante em diversas instituições do Brasil, como UnB, Unicamp e Unirio. Foi 
orientador de alguns pesquisadores brasileiros na Inglaterra e é um entusiasta da cultura brasileira.

Além do contato com as atividades do PPP, a experiência na Queen Mary foi excelente para aproveitar a vasta biblioteca da universidade, e também para relatar os avanços da pesquisa no Quorum, o fórum dos pesquisadores do Departamento de Drama da QMUL. As atividades de pesquisa durante o estágio no exterior estavam centradas em quatro eixos: pesquisa bibliográfica; pesquisa em sites e newsletters dos coletivos; participação e registro de protestos e eventos; e criação de uma rede de contatos e interação com os indivíduos e coletivos ativistas.

Nem sempre os ativistas tem interesse ou disponibilidade para se relacionar com pesquisadores. Por vezes eles se sentem explorados, "alvo de análise", "objeto de pesquisa", e se recusam a cooperar. Em outras, consideram que a pesquisa acadêmica (assim como o jornalismo) presta um serviço a uma ou mais "instituições de poder" (a universidade que abriga a pesquisa; o estado ou a iniciativa privada que a financia), e também há uma recusa. Um terceiro sentimento é um certo desprezo àqueles "dedicados à teoria" e, por exclusão, "afastados da prática". Ainda que eu compartilhe apenas parcialmente dessas opiniões, acho que é necessário fazer uma crítica do processo de pesquisa à luz destas análises. De que maneira a pesquisa acadêmica contribui de maneira emancipatória, revolucionária, para a rede de ativismo político contemporâneo e até que ponto ela é instrumento de aprisionamento e domesticação deste tipo de iniciativas?

Tive melhor resultado no estabelecimento da rede de contatos e interação com os ativistas quando me coloquei não apenas como pesquisador, mas como ativista também. Aí a relação com os indivíduos e coletivos se tornou mais igual e pude compartilhar informações e experiências. Colaborando com o coletivo Space Hijackers consegui registrar e documentar os protestos festivos do MayDay, além de acompanhar o desenvolvimento de ações subsequentes. Em Leeds, participando de uma conferência proferida pelo professor Zygmunt Bauman, pude trocar impressões e conhecer projetos de estudantes do departamento de comunicação da Universidade de Leeds, com quem 
mantenho contato frequente. Na Suíça mantenho contato com alguns ativistas, que continuam me informando sobre a cena local. O mesmo vale para o coletivo inglês Unimundal Monad, com quem mantenho trocas de mails. A parceria com a performer inglesa Lottie Child se materializou em sessões de Street Training no Brasil e um projeto de extensão na Unicentro, em Guarapuava. Com contatos feitos na Espanha, tenho projetos de obras artísticas colaborativas envolvendo psicogeografia e deriva.

Contudo, o evento onde consegui criar o maior volume de contatos e de onde extraí mais frutos para a pesquisa foi a conferência europeia da Ação Global dos Povos (AGP), realizada em agosto de 2008 em Alexandroupolis, na Grécia. Durante uma semana, ativistas de toda a Europa estiveram reunidos para discutir e formular estratégias de resistência articuladas. $\mathrm{Na}$ conferência pude propor o workshop "Criatividade e Luta: a Poética da Resistência", no qual coletei depoimentos de protestos criativo de grupos e ativistas da Alemanha, Hungria, Grécia, Rússia (fui convidado a apresentar um painel sobre minha pesquisa em Moscou, em junho de 2009, mas infelizmente não pude participar), Holanda e França.

Um dos grupos franceses contactados nesta ocasião foram os ocupantes do Espace Autogeré de les Tanneries, em Dijon, onde pude realizar uma vivência de acompanhamento de suas atividades cotidianas (a partir da ideia de "intercâmbio radical", uma troca de experiências sugerida em um dos workshops da conferência da AGP) durante uma semana, em novembro de 2008. Les Tanneries foi o coletivo anfitrião da penúltima conferência europeia da PGA (em 2006), e é reconhecido como um dos mais bem sucedidos espaços autogeridos da Europa. A ideia de Les Tanneries (e de muitos outros coletivos libertários) é de que não há necessidade de participar da maioria das atividades de consumo impostas pelo capitalismo, e tentar ser o mais independente de dinheiro possível. Por isso, a comida que eles comem é reaproveitada do lixo, o transporte é bicicleta ou carona e a moradia é ocupada (squat). O espaço ocupado por eles era antigamente um curtume, e foi transformado em centro social em 1998. Há uma excelente biblioteca, conectada com outras bibliotecas libertárias francesas; um infoshop anarquista, de onde peguei uma série de revistas, jornais, 
manifestos, etc; um freeshop chamado "zone de gratuité", de onde pode-se pegar roupas sem pagar nada por elas; uma enorme oficina de bicicletas; uma oficina de computadores; uma área de projeção de filmes; uma cozinha coletiva; e um jardim libertário em um terreno vizinho.

As vivências com o ambiente ativista europeu (especialmente na conferência da AGP e em Les Tanneries) proporcionaram uma salutar interferência no processo de pesquisa. Outras contribuições substanciais foram as entrevistas com autores trabalhando com e sobre ativismo. Dentre elas, destaco a conversa que tive em Paris com Brian Holmes, crítico da cultura e ativista, colaborador com coletivos artísticos e ativistas como o Bureau d'Etudes e o Ne pas plier, e autor de diversos ensaios sobre a interface entre arte contemporânea e ativismo político. A entrevista está anexada no final deste volume.

Dada a natureza híbrida e indisciplinar do prank, objeto de estudos selecionado como recorte de pesquisa, a redação desta tese é atravessada por reflexões de áreas diversas, como a teoria da arte e do teatro, a ciência política, a filosofia, a sociologia e a história contemporânea. O primeiro capítulo da tese é uma incursão sobre a organização em rede tanto das estruturas de poder do capitalismo contemporâneo quanto da resistência que se articulou em oposição a ele. Para contextualizar as ações da rede de resistência do ativismo político contemporâneo e a opção performativa de alguns de seus participantes pela prática do prank, traço um panorama dos principais eventos desta rede entre 1994 (ano do paradigmático levante zapatista no México) e 2003 (ano da maior cooperação mundial de protestos da história, contra a invasão do Iraque, em fevereiro). Neste percurso, abordo a criação da AGP e sua coordenação dos Dias de Ação Global; o Carnaval contra o Capitalismo e o surgimento do Reclaim the Streets; o bloqueio à reunião ministerial da Organização Mundial do Comércio em Seattle, em 1999; a criação da Indymedia e a ação dos Black Bloc; a organização do Fórum Social Mundial; os protestos contra a reunião de cúpula do G8 em Gênova, em 2001; a participação dos Tute Bianche nas manifestações; as duras consequências dos 
eventos de 11 de setembro de 2001 para a rede de ativismo político contemporâneo e um gradativo esgotamento do modelo de macroações após 2003.

No segundo capítulo, qualifico diferentes modalidades de pranks, buscando estabelecer diferenças e semelhanças entre elas. A fim de refletir sobre estratégias facilitadoras do prank, apresento o conceito de fantasmas coletivos, proposto por Brian Holmes e exemplificado pelas performances de Luther Blissett. Identifico ecos deste conceito tanto na prática do EZLN quanto nas do Black Bloc, Reclaim the Streets e Tute Bianche. Outra categoria que aproveito da leitura de Brian Holmes e que se revela instrumental para a discussão dos pranks é a de representação direta. Busco avaliar as características de autoexpressividade, emancipação estética e "faça você mesmo" deste conceito que Holmes detecta nas performances ativistas para verificar a proximidade destas com procedimentos de determinadas práticas da história da arte, como a arte conceitual, o dadá, a body art, o happening e a performance art. Também uma acepção mais larga de performance, que escapa à circunscrição exclusiva da arte, tal como entendida por Richard Schechner e Jon Mckenzie, se mostra interessante para a avaliação dos pranks. Isto é especialmente verificável quando adotamos, de forma extrateatral, as categorias formuladas por Josette Féral para examinar o teatro contemporâneo, a teatralidade e a performatividade.

O prank como elemento de disputa do espaço é o tema do terceiro capítulo. $\mathrm{Na}$ primeira parte deste capítulo, o espaço é entendido como o espaço urbano contemporâneo, domesticado pelo capital. Os pranks são apresentados como estratégias de ruptura desta domesticação, começando com o exemplo do Street Training, conduta não usual, atlética, lúdica e performativa de afetar o ambiente circundante. O Street Training faz parte de uma longa tradição de exploração disruptiva do espaço urbano, que engloba desde o flaneur de Charles Baudelaire e Walter Benjamin, passando pelos passeios dadá, as deambulações surrealistas e as derivas situacionistas. Esta tradição insurrecional se aproxima da reescrita performativa do espaço através do que o coletivo Space Hijackers chama de anarquitetura. As performances do Street Training e dos Space Hijackers como 
"momentos de insurreição" ou "experiências de pico" são exemplos da instauração de uma Zona Autônoma Temporária, conforme formulada por Hakim Bey. Este autor também orienta os procedimentos dos Delinquentes, Inconsequentes e Dementes, grupo curitibano que funde ativismo e vandalismo em seus pranks. Concluo o subcapítulo refletindo sobre pranks cujas performances indicam um posicionamento de emancipação do espaço urbano à primeira vista, mas que acabaram sendo absorvidas pela indústria cultural, como é o caso dos flash mobs.

A discussão sobre a cooptação dos pranks ativistas como parte de um imaginário cool pelo mundo da publicidade, do mercado de arte e do entretenimento (assim como as estratégias de resistência a essa cooptação) é o tema da segunda parte do terceiro capítulo. Nele, o espaço em disputa é entendido de forma não material, como espaço de trocas simbólicas. Os exemplos apresentados realizam os seus pranks sob a orientação do culture jamming, isto é, distorcendo os conteúdos e formas adotados pela mídia corporativa, voltando as "armas do inimigo" contra ele próprio. Assim, se por um lado empresas como a Ecko e a Volkswagen incorporam pranks como estratégia de marketing (e também coletivos como a Adbusters e o artistaativista Banksy mantém uma relação de ambiguidade com o mercado), por outro lado, coletivos como o Yomango, os Confeiteiros sem Fronteira e os Yes Men se dedicam a formular e executar performances cujos símbolos sejam dificilmente incorporados pela lógica da mercadoria.

Pode-se perceber nas performances selecionadas como exemplo neste trabalho uma predominância de coletivos ativistas europeus. Isso se deve, em parte, pela rede de contato estabelecida durante o período de estágio de pesquisa no exterior. Outro fator decisivo foi a predominância de alguns coletivos na bibliografia analítica especificamente utilizada neste trabalho. Autores como Michael Hardt, Antonio Negri, Brian Holmes, John Jordan, Paul Kingsnorth, Ned Ludd, Naomi Klein, Mark Dery, Jenny Jung, Audrey Watters e o coletivo Notes from Nowhere foram fundamentais para a seleção dos exemplos abordados. Como toda seleção, ela foi um processo parcial e vinculado aos objetivos específicos da pesquisa, ou seja, contemplar os 
coletivos que incorporavam os pranks como elemento lúdico, crítico e multiplicador em suas performances políticas que visassem a disputa do espaço (físico e simbólico). Certamente não se trata de uma seleção que dá conta da totalidade do fenômeno, e nem há esta pretensão extensiva. Vários coletivos e indivíduos ativistas relevantes ficaram de fora (Clandestine Insurgent Rebel Clown Army, Pink \& Silver, No vas a tener casa em la puta vida, Radical Cheerleaders, Rhythms of Resistance, Infernal Noise Brigade, Joey Skaggs, Guerrila Girls, Reverend Billy, 0100101110101101.org, só pra citar alguns), e merecem ser contemplados em futuras pesquisas sobre este tema ou sobre temas correlatos.

No âmbito da pesquisa brasileira, a tese que apresento estabelece um diálogo com as dissertações de Pedro Diniz Bennaton, Deslocamento e invasão: estratégias para a construção de situações de intervenção urbana, apresentada no Programa de Pós-Graduação em Teatro do CEART-UDESC; e de Júlia Ruiz Di Giovanni, Seatle, Praga, Gênova: política antiglobalização pela experiência da ação de rua, apresentada no Programa de Pós-Graduação em Antropologia Social da FFLCH-USP. No entanto, pela proximidade do recorte de objeto, seleção de exemplos e bibliografia, percebo uma maior proximidade com as dissertações de Érico Assis, Táticas lúdicomidiáticas no ativismo político contemporâneo, defendida junto ao Programa de PósGraduação em Ciências da Comunicação da UNISINOS; e de André Mesquita, Insurgências poéticas: arte ativista e ação coletiva (1990-2000), defendida junto ao Programa de Pós-Graduação em História da FFLCH-USP. Agradeço a todos estes pesquisadores pela disponibilidade no envio de seus trabalhos e por oferecer outros olhares ao objeto de estudo que me interessava.

Por fim, gostaria de reiterar meus agradecimentos à Capes, agência que financiou tanto a etapa nacional quanto o estágio de pesquisa no exterior; aos professores da USP e da Queen Mary, que deixaram suas marcas neste trabalho, em especial ao professor Luiz Fernando Ramos, meu orientador, e ao professor Paul Heritage, meu coorientador; aos demais professores que fizeram parte da minha trajetória; à banca de avaliação deste trabalho; aos ativistas que colaboraram com o 
andamento desta pesquisa; aos membros e ex-membros da Kiwi Companhia de Teatro, onde boa parte da inquietação que me move artística e academicamente foi gerada; aos meus amigos que souberam amparar, apoiar, incentivar e comemorar sempre que necessário; aos meus familiares, que torceram pelo sucesso mesmo nos momentos de crise; e a Larissa Nowak, que esteve junto a mim com seu amor. 


\section{TODOS NÓS QUE RESISTIMOS}

Somos invencíveis porque somos todo mundo. Não podem nos prender porque não existimos.

Angry Brigade

Ao longo dos últimos trinta anos tem havido um enfraquecimento do papel dos Estados Nacionais (em especial daqueles afastados do protagonismo da economia mundial); um fortalecimento do poder econômico e político das grandes empresas (as corporações); e um fluxo de capitais vertiginoso, facilitado pela flexibilização das legislações trabalhistas nos países periféricos e pela afirmação do capital especulativo transnacional. Pela reivindicação de uma prática de "livre mercado", ou seja, em que a regulação das relações de poder não deve se submeter ao aparato burocrático dos Estados Nacionais, mas às "leis" da "mão invisível do mercado", este momento é chamado de neoliberalismo ${ }^{8}$. De acordo com Milton Friedman, um de seus principais ideólogos, sob o "livre-mercado" o Estado deveria se restringir a "proteger nossa liberdade tanto dos inimigos externos quanto dos nossos próprios cidadãos: preservar a lei e a ordem, garantir os contratos privados e proteger mercados competitivos" 9 . Ou seja, um Estado vigilante e policial simplesmente, deixando para o mercado o papel de árbitro supremo das relações sociais.

Outro termo também usado para descrever este processo de rarefação da soberania dos Estados Nacionais e a interdependência econômica em escala mundial é globalização. Para Eric Hobsbawn, este termo descreve um "mundo visto como um conjunto único de atividades interconectadas que não são estorvadas pelas fronteiras

Ainda que o termo invoque o laissez-faire econômico, Antonio Negri e Michael Hardt duvidam desta liberdade: "Não existe em absoluto algo como um mercado livre. Trata-se simplesmente de um mito. (...) Por trás de toda negociação trabalhista estão o poder político e sua ameaça de uso da força. Se não houvesse uma regulação política, ou seja, nenhuma relação de força para resolver os conflitos do trabalho, não existiria um mercado capitalista." HARDT, Michael e NEGRI, Antonio. Multidão. Rio de Janeiro: Record, 2005, p. 219.

9 FRIEDMAN, Milton. Capitalism and freedom. Chicago: University of Chicago Press, 1982, p. 2. apud KLEIN, Naomi. The shock doctrine - the rise of disaster capitalism. Nova York: Metropolitan Books, 2007, p. 5 . 
locais" $" 10$, o que significa que esta fase do modo de produção capitalista inaugura uma diferente relação com a organização do espaço. O poder econômico é emancipado de sua territorialidade, e passa a ser nômade. Esta mobilidade demanda uma nova organização estrutural do poder: o modelo piramidal, no qual há uma liderança no topo e uma base de subordinados não atende mais às expectativas e demandas do capitalismo atual. A estrutura preponderante passa a ser a rede.

A metáfora da rede para descrever a dinâmica do poder (e do contrapoder), e as articulações entre os indivíduos e grupos participantes desta dinâmica, é predominante, em especial dentro de coletivos ativistas e autores simpáticos a esses coletivos ${ }^{11}$. Esta predominância, aliada à popularização do uso da metáfora pra se referir à internet, pode levar a uma adesão imediata e irrefletida ao termo. Para Harry Cleaver, no entanto,

uma rede é um tecido construído por nós interligados - o que em termos sociais significa grupos interligados. Isso é aplicável quando os grupos são facilmente identificáveis e cooperativos. (...) Falta, no entanto, o sentido do movimento fluído e incessante dentro da "sociedade civil" no qual "organizar" pode não formar "organizações", mas uma vazão e fluxo de contato em pontos inumeráveis. ${ }^{12}$

Cleaver elege a metáfora da hidrosfera para pensar neste movimento incessante da vida política. A água se move por vezes rapidamente, por vezes lentamente, aquece, esfria, vai para a superfície, volta para o fundo, e só se cristaliza, se congela, momentaneamente em formas que poderiam ser "organizações”. No entanto, ela volta a derreter e retoma seu processo dinâmico de autodeterminação ${ }^{13}$.

Em que pese a coerência e a propriedade da metáfora da água, podemos ampliar nosso olhar sobre o conceito de rede, pensando-a sem a mesma "determinação" que Cleaver lhe atribui, mas percebendo-a em formas "flexíveis, fluidas, plurais e descentralizadas"14. Os "nós" da rede podem se unir apenas para perseguir objetivos

HOBSBAWM, Eric. Globalização, democracia e terrorismo. São Paulo: Cia das Letras, 2007, p. 11.

11 Penso especialmente (mas não exclusivamente) em Michael Hardt e Antonio Negri, para quem a formulação das categorias Império e Multidão está atrelada à ideia de rede.

12 CLEAVER, Harry. "Computer-linked Social Movements and the Global Threat to Capitalism” . Disponível em http://www.eco.utexas.edu/faculty/Cleaver/polnet.html - Acesso em 31 de maio de 2009.

13 Assim como Cleaver, o coletivo Critical Art Ensemble e o sociólogo Zygmunt Bauman elegem a metáfora do "líquido" para descrever relações econômicas, culturais e políticas na contemporaneidade.

14 ORTELLADO, Pablo. "Sobre a passagem de um grupo de pessoas por um breve período da história" in 
específicos, respeitando princípios e objetivos comuns gerais acordados. Isso quer dizer que há uma autonomia e descentralização na rede, motivadas pela qualidade de livre-associação e por sua qualidade correlata, a livre-dissociação. A rede não pretende a instauração de um sistema representativo, mas busca estimular práticas diretas e horizontais. Na rede, não há centro, não há "dentro" ou "fora". Se um de seus "nós" for desconectado, as várias outras conexões compensam a desconexão. A indeterminação da rede, seu aspecto mutável e fugidio, faz com que ela seja, ao mesmo tempo, onipresente e impalpável. É com este sentido mais amplo da metáfora rede que o termo será empregado ao longo deste trabalho.

Mesmo que alguns pontos da rede de poder continuem facilmente identificáveis (o complexo de órgãos de governo, que envolvem força militar, policial, fiscal, legislativa, administrativa, etc; as grandes corporações e seu corpo de acionistas), outros são relativamente novos (vigilância eletrônica, conglomerados de telecomunicação, tratados e instituições supranacionais [como OMC, TRIPS, GATS, etc]).

O modus operandi deste modelo de poder em rede também apresenta características novas. Um exemplo é a organização do trabalho. Cada vez mais o trabalho produz bens imateriais. O paradigma industrial que organizou a produção ao longo de pelo menos 150 anos dá lugar a uma lógica na qual os produtos são o conhecimento, a informação, a comunicação, as relações emocionais.

Podemos conceber o trabalho imaterial em duas formas fundamentais. A primeira refere-se ao trabalho que é primordialmente intelectual ou linguístico. (...) Esse tipo de trabalho imaterial produz ideias, símbolos, códigos, textos, formas linguísticas imagens e outros produtos do gênero. Chamamos a outra forma fundamental de trabalho imaterial de "trabalho afetivo". O trabalho afetivo, assim, é o trabalho que produz ou manipula afetos como a sensação de bem-estar, tranquilidade, satisfação, excitação ou paixão ${ }^{15}$.

Negri e Hardt sublinham que esta produção imaterial é biopolitica, ou seja, é um tipo de trabalho que resulta na produção da própria vida social. $\mathrm{O}$ trabalho

RYOKI, André e ORTELLADO, Pablo. Estamos vencendo - resistência global no Brasil. São Paulo: Conrad, 2004. Col. Baderna, p. 17.

15 HARDT e NEGRI, op. cit., p. 149. 
imaterial, por ser biopolítico, concerne à produção e à reprodução da subjetividade da sociedade. É uma convergência entre o econômico, o político, o social e o cultural. Em termos de deslocamento do modo de produção da base material, esta análise se aproxima da teoria do espetáculo, de Guy Debord.

Em A Sociedade do Espetáculo, livro publicado em 1967, Debord detecta a emergência da imagem (e, portanto, da representação) como categoria fundamental de produção no capitalismo de então. Há um estreitamento e uma intimidade entre espetáculo, capital e imagem, apontados por Debord: “o espetáculo é o capital em tal grau de acumulação que se torna imagem" ${ }^{16}$. A imagem ocupa, em Debord, um papel equivalente ao que a mercadoria ocupava em Marx. No espetáculo, as imagens são produzidas industrialmente sob a lógica da forma-mercadoria e invadem o cotidiano. A imagem virou mercadoria e vice-versa, em um entrelaçamento entre o modo de produção e sua representação. Esta transmutação entre mercadoria e imagem acaba por englobar as relações sociais. A linguagem e o imaginário são sugados para dentro do mercado, e passam a ser o meio através do qual o capital se reproduz. Por isso, "o espetáculo não é um conjunto de imagens, mas uma relação social entre pessoas, mediada por imagens" ${ }^{17}$. Isto significa que a profusão de imagens em si não é suficiente para configurar o espetáculo, mas quando estas imagens se tornam tão fundamentais que sustentam as relações de produção, o espetáculo está estabelecido.

Claro que a leitura de Debord e a de Negri e Hardt não são coincidentes, os projetos são distintos, e os contextos sob os quais suas obras foram produzidas são bastante diferentes. No entanto, ambas apontam para este abandono da produção de "coisas tangíveis" para privilegiar a produção de imagens, ideias, relações. Na história do capitalismo, esta mudança na base produtiva significa que, após o capitalismo mercantil e o capitalismo industrial, as características de imaterialidade apontam para um novo paradigma de produção, pós-industrial, o capitalismo cognitivo.

\footnotetext{
16 DEBORD, Guy. A sociedade do espetáculo e Comentários sobre a sociedade do espetáculo. Rio de Janeiro: Contraponto, 1997, parág. 34.

$17 \quad$ Ibid. parág. 4.
} 
As especificidades do trabalho sob este novo paradigma formam uma nova classe social, do proletariado cognitivo, ou cognitariado ${ }^{18}$. Dos meios de produção desta classe fazem parte as tecnologias de produção e compartilhamento de informações digitais. Além disso, estes trabalhadores estão acostumados a uma flexibilização, mobilidade e precarização dos contratos de trabalho; a um regime cooperativo de criação em que as relações hierárquicas se dão de modo não-linear; ao desaparecimento da distinção entre horário de trabalho, de consumo e de lazer; e à realização de atividades criativas, intelectivas, relacionais e comunicacionais. O trabalho do cognitariado é biopolítico e realizado em rede. Para que ele possa emergir, é necessário que esta rede teça o comum que é o repertório por meio do qual os bens imateriais são criados ${ }^{19}$.

O comum que compartilhamos, na realidade, é menos descoberto do que produzido. (...) Esta produção do comum tende atualmente a ser central a todas as formas de produção social, por mais acentuado que seja seu caráter local, constituindo na realidade a característica básica das novas formas dominantes do trabalho hoje. (...) Todo aquele que trabalha com a informação ou o conhecimento (...) depende do conhecimento comum recebido de outros e por sua vez cria novos conhecimentos comuns. (...) Esta produção biopolítica e a expansão do comum que acarreta é um dos principais pilares em que se assenta hoje a possibilidade da democracia global $^{20}$.

De acordo com Negri e Hardt, a multidão é a subjetividade que surge da dinâmica e partilha do comum. Por isso, é sua tarefa a reapropriação e gestão do comum, de tudo que é geral ou público. A multidão é a carne de um corpo político que também se estrutura em rede: uma rede aberta na qual singularidades e diferenças não apenas convivem, mas são expressas e exercidas livre e igualitariamente, de maneira convergente, tendo como recurso e objetivo a produção do comum. Para Negri e Hardt, só a multidão, em seu compromisso íntimo com a democracia, é capaz de

18 BERARDI (BIFO), Franco. "Desobedience and Cognitariat". Disponível em www.pushthebuttonplay.com/dlwd/ scotini/disobedience/pdf/interview bifo-scotini en.pdf - Acesso 15 de maio de 2008.

19 Comum é a tradução do conceito de commons: "Commons pode ser traduzido como comum ou como espaço comum. Seu significado também comporta a noção de público em oposição a algo que é privado. Seu uso evoca ainda a ideia de algo que é feito por todos ou por coletivos e comunidades. Os commons pretendem expressar recursos que são comuns. Bens públicos são commons." SILVEIRA, Sérgio Amadeu da. "O conceito de commons". Disponível em http://www.aepidemia.org/noticia/commons-cibercutura Acesso em 15 de maio de 2008.

20 HARDT e NEGRI, op. cit., pp. 14-15. 
empreender uma resistência ao Império, corpo político que adota práticas do que chamamos neoliberalismo, globalização ou capitalismo cognitivo.

Transversalmente às mudanças ocorridas na esfera produtiva (organização biopolítica do trabalho imaterial, flexibilização e precarização das relações trabalhistas, desterritorialização do capital e do poder, etc) há uma difusão tecnológica que é, ao mesmo tempo, consequência e causa das mudanças econômicas. O jornalista Thomas Friedman considera que "a globalização é definida por suas tecnologias: computarização, miniaturização, digitalização, comunicação por satélite, fibra ótica e internet, que reforçam uma perspectiva definitiva de integração" ${ }^{21}$. Estas ferramentas de comunicação, digitalização e transmissão telemática de dados acabam por formar uma infraestrutura rizomática que atende, ambiguamente, aos anseios de vigilância e controle do Império, e aos processos de organização e gestão do comum da multidão.

Obviamente o processo de cerceamento da liberdade nos espaços virtuais já se encontra a pleno vapor, como demonstra a recente aprovação na assembleia nacional francesa da Lei Hadopi (sigla para Alta Autoridade para a Difusão de Obras e Proteção de Direitos na Internet), que restringe e coíbe práticas de compartilhamento e downloads de informações online. O mesmo ocorre, no âmbito brasileiro, com o Projeto de Lei 89/03, aprovado no Senado, que define quais são as "condutas criminosas" na internet e amplia a possibilidade de vigilância sobre os usuários da rede.

Por outro lado, e em oposição às constantes tentativas de bloquear o fluxo de informação na rede de computadores, há uma prática constante de uso da internet como sistema de distribuição do comum, de compartilhamento de informações, experiências, estratégias e táticas, com a intenção do fortalecimento da rede colaborativa da multidão.

Em face do capitalismo transnacional, uma rede de resistência nasceu, local e global, tática e estratégica: uma nova forma de dissidência política, auto-organizada e anarquista, difusamente interconectada e operada de baixo

21 FRIEDMAN, Thomas. The lexus and the olive tree. Nova York: Anchor Books, 2000, p. 20 apud SCHECHNER, Richard. Performance studies: an introduction. Londres e Nova York: Routledge, 2006. p. 266. 
para cima, e ainda assim capaz de atingir as maiores concentrações de poder. Qual é a força destes movimentos? O improvável apelo de uma "geopolítica do faça você mesmo": uma chance de envolvimento pessoal na transformação do mundo.

Estas ações estão o mais distante que se possa imaginar de um museu, ainda assim, quando nos aproximamos delas, podemos sentir algo artístico. Elas unem a multiplicidade da expressão individual e a unidade do desejo coletivo. Este é o seu enigma, que estabelece uma circulação entre singularidade e solidariedade, cooperação e liberdade ${ }^{22}$.

Não há consenso sobre como chamar esta rede, e quais atores sociais incluir ou excluir, já que a própria natureza da rede é indeterminável. Uma primeira discussão é se esta rede representa ou não um "movimento". Podemos pensar que um movimento designa um conjunto de ações e agentes em direção a um objetivo comum. Isto não é tão verificável nesta rede de resistência, pois, ainda que haja uma oposição comum às práticas do modo de produção capitalista, a proposição "em direção" a que se caminha não é homogênea. A multiplicidade das lutas, das reivindicações, das metodologias e mesmo da imagem de futuro fizeram alguns autores chamarem esta rede e suas ações de "Movimento de Movimentos"23. Outros autores, e boa parte da mídia, preferem caracterizar o mesmo movimento (ou um grupo de atores sociais muito próximo dele) de "Anti-Globalização". No entanto, isto não é suficientemente preciso ${ }^{24}$, já que este movimento se opõe a aspectos degradantes de um conceito que seria, em tese, positivo (afinal, globalização pode sugerir a integração utópica de todo o planeta, virtualmente presente na difusão da internet, por exemplo). Seria necessário precisar a que tipo ou a que características da globalização o movimento se opõe. Uma possibilidade seria "Movimento Anti-Globalização Corporativa", isto é, uma oposição ao projeto políticoeconômico em que os interesses das grandes empresas estão privilegiados em detrimento dos interesses comuns e públicos. Mais uma maneira de se referir à mesma rede é "Movimento de Justiça Global" 25. Também encontramos o uso de “Altermundialismo", numa referência ao lema do Fórum Social Mundial - "Um outro

22 HOLMES, Brian. Unleashing the collective phantoms: essay in reverse imagineering. New York: Autonomedia, 2008, p. 56.

23 MERTES, Tom (org). A Movement of Movements - is another world really possible? Londres: Verso, 2004.

24 E vários ativistas consideram mesmo depreciativo.

25 DELLA PORTA, Donatella. The Global Justice Movement: Cross-national And Transnational Perspectives. Nova York: Paradigm, 2006. 
mundo é possível". Mesmo a proposição de Hardt e Negri, de "Multidão" busca conceituar (ainda que de forma aberta) um sujeito democraticamente ativo e anticapitalista. É claro que a formulação e a escolha da terminologia pela qual são evocados fenômenos ou sujeitos similares passam por crivos ideológicos, filiações políticas e históricas, etc. Como este trabalho tem o objetivo específico de abordar a prática dos pranks, não pretendo privilegiar nenhum destes conceitos. Antes, pretendo, neste capítulo, apresentar um panorama para contextualizar as ações, motivações e interações desta rede de resistência, que será agrupada sobre a denominação genérica de "ativismo político contemporâneo". Assim, mesmo ciente dos diferentes relevos de cada um dos termos que diferentes autores usam para denominar esta rede, uso-os indistintamente.

Ainda que seja evidente que o ativismo crítico ao modo de produção capitalista tenha suas raízes históricas no século $\mathrm{XIX}^{26}$, e manifestações explícitas ao longo do século $\mathrm{XX}^{27}$, uma convenção localiza como marco na história contemporânea desta rede o levante do Exército Zapatista de Libertação Nacional (EZLN), no México ${ }^{28}$.

Após sua insurgência concomitante à implantação do NAFTA (Tratado de Livre-Comércio da América do Norte), em primeiro de janeiro de 1994, o EZLN adotou práticas que o transformou em paradigma para o ativismo político contemporâneo. "O EZLN atraiu atenção mundial por suas características inusitadas era um levante basicamente indígena, cujas demandas estavam ao mesmo tempo relacionadas a conflitos de raça, autonomia, gênero, política, economia e globalização"29. A consciência primordial dos zapatistas foi reconhecer que a sua luta,

26 A "luta de classes", para usar um termo marxista, não é privilégio dos nossos tempos. Se quiséssemos, poderíamos mencionar revoltas de escravos na Roma Antiga, ou de camponeses europeus no Renascimento. Após a Revolução Industrial, no entanto, o parentesco das insurgências com o ativismo político contemporâneo é mais evidente. Pensemos, por exemplo, nas sabotagens do movimento Luddita, na década de 1810, ou na Comuna de Paris, em 1871.

27 Aqui os exemplos podem ser vários. Os desdobramentos de Maio de 68, em diversos países do mundo; o movimento antiguerra do Vietnã, nos anos 60-70 e os primeiros grupos ecologistas das décadas de 80 e 90 podem ser ressaltados por deixar marcas e inspirações profundas no ativismo contemporâneo.

28 É esta, por exemplo, a opinião de Brian Holmes, em entrevista realizada em 10/11/2008, anexada ao final desta tese. Também o artista e pesquisador Marcelo Expósito concorda com o aspecto inaugural do zapatismo para o ativismo contemporâneo, chamando-o de "Big Bang zapatista". http://www.hamacaonline.net/ autor.php?id=69

29 ASSIS, Érico Gonçalves de. Táticas lúdico-midiáticas no ativismo político contemporâneo. Dissertação de mestrado apresentada ao programa de pós-graduação em Ciências de Comunicação da UNISINOS, São 
na selva Lacadona, em Chiapas, sudeste mexicano, não era uma guerrilha isolada confrontando um governo. Pelo contrário, fazia parte de uma enorme rede de resistência que ainda precisava ser construída. Após um período de embate com as forças militares mexicanas e intensa relação com as comunidades, propondo uma Consulta pela Paz e Democracia, o EZLN convocou para julho de 1996 o I Encontro Intercontinental pela Humanidade e contra o Neoliberalismo, que ficou conhecido como Intergalático. Este encontro celebrou a diversidade das lutas dispersas pelo planeta, e firmou o propósito de tecer uma rede intercontinental de resistência.

Esta rede (...), reconhecendo diferenças e conhecendo semelhanças, tentará se encontrar com outras resistências do mundo inteiro. (...) Será o meio pelo qual as diversas resistências se apoiarão umas às outras. Esta rede (...) não é uma estrutura organizativa, não tem centro de direção nem de decisão, não tem comando central nem hierarquias. A rede somos todos nós que resistimos. ${ }^{30}$

A ferramenta ideal para este propósito era a emergente rede de computadores, que facilitava a comunicação entre os grupos dissidentes. Negri e Hardt consideram que os zapatistas foram um pivô entre velho modelo guerrilheiro (afinal, a ocupação inicial em San Cristóbal de las Casas, e todos os demais conflitos que opuseram o EZLN e o exército mexicano foram conflitos armados) e um novo modelo de estruturas biopolíticas em rede (e, neste caso, a adoção estratégica dos meios digitais de comunicação é sintomática) ${ }^{31}$.

O objetivo do EZLN não é derrotar o estado, mas mudar o mundo sem tomar o poder $^{32}$. Nisso rompe com o projeto de parte da esquerda histórica.

A questão do poder, ou para ser mais exato, a questão do não-poder, tem feito do zapatismo algo "herético" aos olhos das esquerdas históricas, radicais ou social-democratas. Trata-se da passagem da figura do "revolucionário" (ou de sua versão débil, soft, o "reformista"), que quer tomar o poder para mudar o mundo, à figura do rebelde, que, pelo contrário, quer pôr em discussão o poder e corroer seus fundamentos, para dar vida a formas de participação paralelas, alternativas e auto-organizadas da sociedade civil. A prática zapatista não pretende formular um novo mundo, senão que experimenta e faz alusão à construção de muitos mundos possíveis. Portanto, mais do que uma teoria ou uma ideologia, o zapatismo

Leopoldo, 2006, p. 31.

30 GENNARI, Emilio. EZLN - passos de uma rebeldia. São Paulo: Expressão Popular, 2005, p. 86.

31 HARDT e NEGRI, op. cit., p. 123.

32 Ver HOLLOWAY, John. Change the world without taking power. Londres: Pluto Press, 2002. 
se apresenta como um método aberto, um hábito mental, infinitamente readaptável. (...) $\mathrm{O}$ zapatismo [pretende] um acesso ilimitado à política, uma abolição dos direitos do autor sobre a política como domínio separado da vida civil cotidiana e levado a cabo pelos capatazes encarregados de fazê1o. ${ }^{33}$

Mas o que interessa especialmente no exemplo zapatista é a construção do imaginário, a mitopoese por trás do movimento. A evocação de Emiliano Zapata, líder militar da Revolução Mexicana na década de 1910 que tirou do poder o ditador Porfírio Diaz, demonstra a adesão ao levante popular e às revoltas camponesas. Este ícone é, por sua vez, misturado "com a mitologia indígena local dos tzeltal, amalgamando-os com relações em rede e práticas democráticas para criar uma nova vida em comum que define o movimento" ${ }^{34}$. A população indígena oprimida forma, de fato, um grande contingente de apoio aos zapatistas.

Outra característica interessante do EZLN é a estratégia utilizada para o rompimento simbólico com a estrutura hierárquica. Os membros do EZLN usam um gorro chamado pasamontañas, uma balaclava que só permite que os olhos sejam vistos. Ou seja, a identidade do guerrilheiro está oculta e preservada. “'A voz que se arma para ser ouvida' vem atrelada 'à face que se esconde para ser vista' e nesses rostos escondidos, segundo os zapatistas, podem ser esboçadas as feições de qualquer pessoa ou de qualquer lugar que se levante para resistir à opressão. Atrás das máscaras, dizem, estamos nós - somos todos zapatistas, e nós estamos em todos os lugares" ${ }^{35}$. A abdicação do rosto do rebelde convoca a comunidade a compartilhar o seu papel. "Esta revolução não tem rosto", foi durante anos a frase de abertura do site da Wu Ming Foundation $^{36}$. Se a revolução não tem rosto, ela não tem um proprietário, uma assinatura. Ela é aberta e inclusiva. Ainda assim, os zapatistas têm um "porta-voz", que assina os comunicados do EZLN como Subcomandante Marcos.

Marcos tem um estilo particular de endereçamento de textos. Seus comunicados revelam um "amplo discurso político iluminado com poesia, humor e contação de

\footnotetext{
33 WU MING. "Zapatismo ou barbárie". Disponível em http://www.wumingfoundation.com/italiano/outtakes/ zapatismo port.html Acesso em 31 de maio de 2009.

34 HARDT e NEGRI, op. cit. p. 276.

35 KINGSNORTH, Paul. Um não, muitos sins - uma viagem aos centros da antiglobalização. Rio de Janeiro: Record, 2006, p. 33.

36 http://www.wumingfoundation.com . Hoje o site não exibe mais esta frase.
} 
histórias"37. Para formular suas mais intensas críticas ao neoliberalismo, por exemplo, ele narra suas conversas com um escaravelho, Don Durito, com quem compartilha o tabaco de seu cachimbo. Um de seus escritos mais conhecidos é um livro infantil, $A$ História das Cores, uma transcrição de uma lenda indígena. O carisma literário de Marcos e seu rosto sob a máscara favoreceram o compartilhamento de sua individualidade. De repente, através do recurso da máscara, Marcos podia estar em vários lugares ao mesmo tempo, como um mito remanipulável. Como diz Naomi Klein, "ele é simplesmente nós: somos o líder que estamos procurando" ${ }^{38}$. Surge o lema "todos somos Marcos".

Marcos é gay em São Francisco, negro na África do Sul, asiático na Europa, hispânico em San Isidro, anarquista na Espanha, palestino em Israel, indígena nas ruas de San Cristóbal, (...) judeu na Alemanha, feminista nos partidos políticos, comunista no pós-guerra fria, (...) pacifista na Bósnia, (...) artista sem galeria e sem portfólio, dona de casa num sábado à noite em qualquer vila de qualquer cidade de qualquer México, guerrilheiro no México do final do século XX, (...) machista no movimento feminista, mulher sozinha no metrô às $22 \mathrm{~h},(\ldots)$ camponês sem terra, editor marginal, operário desempregado, médico sem consultório, estudante inconformado, dissidente no neoliberalismo, escritor sem livros e sem leitores e, sobretudo, zapatista no Sudeste do México.

Enfim, Marcos é um ser humano qualquer neste mundo. Marcos é todas as minorias intoleradas, oprimidas, exploradas, resistindo, dizendo "¡Ya basta!" Todas as minorias na hora de falar e maiorias na hora de se calar e aguentar. Todos os intolerados buscando uma palavra, sua palavra, que devolva a maioria aos eternos fragmentados, nós. Tudo que incomoda o poder e as boas consciências, este é Marcos. ${ }^{39}$

O Segundo Encontro Intergaláctico convocado pelos zapatistas, em 1997, na

Espanha, reuniu importantes atores do ativismo político contemporâneo, dentre eles o

Movimento dos Trabalhadores Rurais Sem Terra (MST) brasileiro, a Confederação

Camponesa francesa e o Sindicato de Agricultores do Estado de Karnataka, indiano.

Este encontro delineou a forma da ferramenta que seria lançada em fevereiro do ano

37 SUBCOMANDANTE MARCOS. Conversations with Durito: Stories of the Zapatistas and neoliberlism . New York: Autonomedia, 2005, p. 7. Há vários de seus textos em http://enlacezapatista.ezln.org.mx e em http://www.bibliotecas.tv/chiapas/comunicados_sub.html. Para dar exemplos de sua verve poética, Marcos endereçou um comunicado ao então presidente mexicano Zedillo se despedindo da seguinte forma: "um pára-quedas para o penhasco que virá com o seu amanhã". E num telegrama à sociedade civil, ele descreve a ofensiva do exército do México e pede reforços: "Os cinzas esperam vencer. Precisa-se de um arco-íris urgente." KINGSNORTH, op. cit., p. 38.

38 KLEIN, Naomi. Sem Logo. Rio de Janeiro: Record, 2002, p. 477.

39 Post-scriptum do "Comunicado de Imprensa do Subcomandante Marcos, 28 de Maio de 1994". Disponível em http://www.bibliotecas.tv/chiapas/may94/28may94.html Acesso em 20 de maio de 2009. 
seguinte, em Genebra - a Ação Global dos Povos. Era a rede de conversa e troca de experiências entre movimentos populares do mundo, "um instrumento global para comunicação e coordenação de todos aqueles que lutam contra a destruição da humanidade e do planeta pelo mercado global, enquanto constroem alternativas locais e poderes populares" ${ }^{40}$. O desejo/lema deste enxame ${ }^{41}$ está expresso no slogan "We are everywhere" ("Estamos por toda parte”). A AGP não é uma organização, um grupo, uma instituição. Não tem membros ou porta-vozes. Antes, é uma ferramenta de coordenação, orientada por alguns princípios:

1. Uma rejeição muito clara ao capitalismo, ao imperialismo, ao feudalismo e a todo acordo comercial, instituições e governos que promovem uma globalização destrutiva.

2. Rejeição a todas as formas e sistemas de dominação e de discriminação incluindo, mas não apenas, o patriarcado, o racismo e o fundamentalismo religioso de todos os credos. Defesa da plena dignidade de todos os seres humanos.

3. Uma atitude de confronto, pois não acreditamos que o diálogo possa ter algum efeito em organizações tão profundamente antidemocráticas e tendenciosas, nas quais o capital transnacional é o único sujeito político real.

4. Um chamado à ação direta, à desobediência civil e ao apoio às lutas dos movimentos sociais, propondo formas de resistência que maximizem o respeito à vida e os direitos dos povos oprimidos, assim como, a construção de alternativas locais ao capitalismo global. autonomia. $^{42}$

5. Uma filosofia organizacional baseada na descentralização e na

A tarefa imediata e bem-sucedida da AGP foi a coordenação dos Dias de Ação

Global, manifestações-bloqueio em encontros de cúpulas de instituições reguladoras do capitalismo mundial, como a Organização Mundial do Comércio (OMC), o Banco Mundial, o Fundo Monetário Internacional (FMI), a Organização do Tratado do Atlântico Norte (OTAN), o G8 ${ }^{43}$, etc. Nas cidades em que tais encontros se davam, e

40 LUDD, Ned. (org.) Urgência das ruas - Black Bloc, Reclaim the Streets e os Dias de Ação Global. São Paulo: Conrad, 2002. Col. Baderna, p. 19.

41 Negri e Hardt desenvolvem a metáfora da inteligência de enxame: "Os enxames que vemos surgir nas novas organizações políticas em rede (...) são compostos por uma multidão de diferentes agentes criativos". op. cit., p. 132.

42 "Princípios da AGP". Disponível em http://www.nadir.org/nadir/initiativ/agp/pt/hallmpt.htm - Acesso em 13 de janeiro de 2009.

43 O G8 inclui as sete nações mais industrializadas e desenvolvidas do mundo (Estados Unidos, Japão, Alemanha, Reino Unido, França, Itália e Canadá), mais a Rússia. 
em inúmeras outras cidades do mundo simultaneamente, os manifestantes tomavam as ruas para protestar.

O ciclo de protestos antiglobalização, lançado nos países desenvolvidos pela ala europeia da rede Ação Global dos Povos em 1998, constitui a primeira erupção desta "frente de resistência total" no território urbano interconectado das cidades-mundiais. Marcadas por uma confluência de movimentos sociais tradicionais, grupos de ativismo de minorias, juventude urbana descontente e produtores culturais rebeldes - artistas visuais e performers, músicos, djs, trabalhadores da mídia e hackers - as manifestações frequentemente tomam a forma de festas techno politicamente orientadas, não eludindo apenas a repressão policial, mas usando todos os recursos da produção cultural coletiva para atingir os lugares e símbolos do controle corporativo sobre as consciências íntimas e a expressão pública.

A ruptura do consenso trazida pelos Dias de Ação Global, iniciados em maio de 1998, serviu pra galvanizar o movimento antiglobalização mais amplo, através de um uso inovativo da internet como um sistema de distribuição mundial operado de baixo para cima. Um conceptualismo autônomo, faça você mesmo, começou a emergir, no qual "atitudes se tornam formas": uma ideia ou frase surgida em uma localidade (por exemplo "Nossa resistência é tão transnacional quanto o capital") se torna uma performance política geograficamente distribuída (as "festas de rua globais" contra as reuniões anuais do G8). ${ }^{44}$

Depois de manifestações contra a OMC em 16 de maio de 98 e durante a reunião do G8 no mesmo ano, o primeiro grande assalto dos Dias de Ação Global foi 18 de junho de 1999 (J18). Considerado por Brian Holmes como um modelo para os demais $^{45}$, o dia concentrou protestos, ação e carnaval, com o epicentro no distrito financeiro de Londres, mas espalhando-se por todo o globo (em pelo menos 40 países). A resistência foi, de fato, tão transnacional quanto o capital. Coincidindo com a reunião do G8 em Colônia, na Alemanha, os protestos daquele dia ficaram conhecidos como Carnaval Contra o Capital. O título dá um pouco do tom das manifestações. Para além das passeatas burocráticas dos sindicatos e partidos de esquerda, o J18 foi uma enorme festa de rua, com dança, música, bicicletada, performances, marchas, etc. Como todo bom carnaval, em Londres, nove mil "foliões" usaram máscaras distribuídas na ocasião.

As autoridades temem a máscara porque seu poder reside parcialmente em identificar, carimbar e catalogar: em saber quem você é. Mas um Carnaval precisa de máscaras, milhares de máscaras; e nossas

HOLMES, op. cit., p. 50 e 166.

45 Entrevista em anexo. 
máscaras não foram feitas para esconder nossa identidade, mas para revelála. (...) A máscara estabelece nossa comunalidade, nos permite agir juntos, gritar em uníssono para aqueles que nos governam e nos dividem: "todos somos loucos, depravados, marginalizados, palhaços e criminosos". Hoje devemos dar um rosto para a resistência; colocando nossas máscaras, revelamos nossa unidade; e levantando nossas vozes nas ruas juntos, nós expressamos nossa revolta para o poder sem face. ${ }^{46}$

Um dos principais articuladores do J18 foi o Reclaim the Streets (RTS: "Reconquiste as ruas"). O grupo surgiu no começo dos anos 90, tendo como principal plataforma a crítica à cultura do automóvel. O RTS reconhecia que esta cultura serve a uma ideologia maior que a sustenta, que é o modo de produção capitalista. "Nós estamos retomando o espaço público do cercamento feito pelo privado. (...) É reclamar as ruas como um espaço público inclusivo em vez de um uso privativo exclusivo dos carros. Mas acreditamos que este seja um princípio mais amplo, o de retomar as coisas que foram cercadas pela circulação capitalista e retorná-las ao uso coletivo como comuns" ${ }^{47}$. As táticas do Reclaim the Streets, que incluíam o fechamento de rodovias e ruas (para o tráfego de veículos motorizados - pedestres e ciclistas tinham livre acesso) para a realização de festas rave, jardinagem libertária (plantação de mudas de árvores em buracos criados no asfalto), caixa de areia para crianças brincarem, teatro e jogos na rua, eram manifestações lúdicas contra o capital. "As características do grupo vêm da mistura da cultura rave com squatters $^{48}$, ecologistas radicais, anarquistas e artistas plásticos, de rua ou de circo" ${ }^{49}$. De acordo com Brian Holmes, "os carnavais do Reclaim the Streets ofereceram um sedutor coquetel de prazer transgressivo, protesto político informado e confrontação direta, o que radicalizou a participação por expor a violência estrutural das relações sociais contemporâneas. (...) [As formas de expressão no J18 incluíam] dança transgressiva, música desafiadora, uma poética da resistência visual e verbal. ${ }^{" 50}$. Antes do J18, o RTS já havia participado de diversos protestos

\footnotetext{
46 "Carnival Against Capital" in Do or Die \#8. Disponível em http://www.eco-action.org/dod/no8/ carnival.html . Acesso em 23 de setembro de 2008.

47 FOURIER, Charlie. "Reclaim the Streets: an arrow of hope" in NOTES FROM NOWHERE. We are everywhere - the irresistible rise of global capitalism. London: Verso, 2003, p. 54.

48 Squatters são os habitantes ou frequentadores dos squats, ocupações coletivas de construções abandonadas ou desabitadas para fins de mobilização política, cultural ou mesmo de habitação. O termo usual em países de língua não-inglesa é okupa.

49 CHRISPINIANO, José. A guerrilha surreal. São Paulo: Conrad e Com-Arte, 2002, p. 92

50 HOLMES, op. cit., p. 76 e 177.
} 
contra a abertura de estradas, como a manifestação na rodovia inglesa M41, em julho de 1996. Em maio de 1998, o RTS coordenou a primeira festa de rua global, com participação de cidades na Alemanha, Austrália, Colômbia, Grécia, Turquia, EUA, Suíça, Eslovênia, República Tcheca e outras. Esta demonstração foi concomitante com a reunião do G8 em Birmingham, e dois dias antes do encontro de cúpula da OMC em Genebra, na Suíça. A novidade metodológica do RTS foi reconhecida pela rede de ativistas que participaram destas manifestações.

Diferente dos protestos políticos convencionais, como as passeatas escoltadas pela polícia ou os discursos nos carros de som realizados por líderes de partidos políticos, grupos de ativistas e de artistas encontraram-se nas festas de rua globais do Reclaim the streets para apropriar-se temporariamente do espaço urbano. Os manifestantes usavam seus corpos, criatividade e música para criar uma experiência de ideais coletivos. (...) Nas festas-protesto do RTS, os ativistas não só enfrentavam a repressão da polícia, mas usavam todas as táticas e performances artísticas possíveis para rapidamente atingir os espaços e símbolos do controle corporativo. ${ }^{51}$

Imaginem uma rua de grande circulação, em plena agitação numa tarde de sábado. (...) Subitamente dois carros se chocam e bloqueiam o trânsito: os motoristas saem e inicia-se um bate-boca. Um deles empunha um martelo e começa a bater no carro do outro. De repente, da multidão anônima surgem pessoas que sobem nos carros, pintando-os anarquicamente com tintas de todas as cores. Sobre o teto dos dois carros destruídos é desdobrada uma enorme faixa, onde se lê: "Reclaim The Streets - Free the city / Kill the cars" ["Reconquiste as ruas - Liberte a cidade / Mate os carros"]. Quinhentas pessoas surgem então do metrô e tomam conta da rua. Como teriam dito os surrealistas, a vida cotidiana estava agora penetrada do maravilhoso. Assim começava a street party [festa de rua] em Camden High Street, no mês de maio de $1995 .^{52}$

O "espírito" Reclaim the Streets, ocupando as ruas com protestos festivos, dançantes, musicais, performáticos, foi absolutamente determinante como elemento aglutinador dos Dias de Ação Global. Independente disso, o grupo manteve como prática uma intensa reflexão sobre suas práticas e sobre o alcance dos seus métodos. Uma coletânea, intitulada Reflections on June $18^{\text {th }}$ ("Reflexões sobre o 18 de junho") reúne textos bastante críticos sobre a admissão de um "papel ativista": "Conceber a si

51 MESQUITA, André. Insurgências Poéticas - arte ativista e ação coletiva (1990-2000). Dissertação de mestrado apresentada ao Programa de Pós-Graduação em História da FFLCH - USP. São Paulo, 2008, pp. 27-28.

52 JORDAN, John. "The Art of Necessity: the Subversive Imagination of Anti-Road Protest and Reclaim the Streets". in MCKAY, George (org.) DIY culture: party \& protest in nineties britain . Londres: Verso, 1998, p. 141. Citado por AGUINTON, Christophe. O mundo nos pertence. São Paulo: Viramundo, 2002, p.140. 
próprio como um ativista significa conceber a si mesmo como sendo alguma espécie de privilegiado (...) significa definir nossas ações como aquelas que trarão a transformação social"'. Outra reflexão da mesma coletânea é sobre as limitações das festas de rua: "o conceito de festa de rua é, na sua forma atual, (...) um fator contribuinte para a espetacularização da resistência, que celebra a ideia de 'festa como protesto', mobilizando repetidamente o mesmo círculo de pessoas, sem nenhum apelo além de um estreito gueto subcultural" 53 .
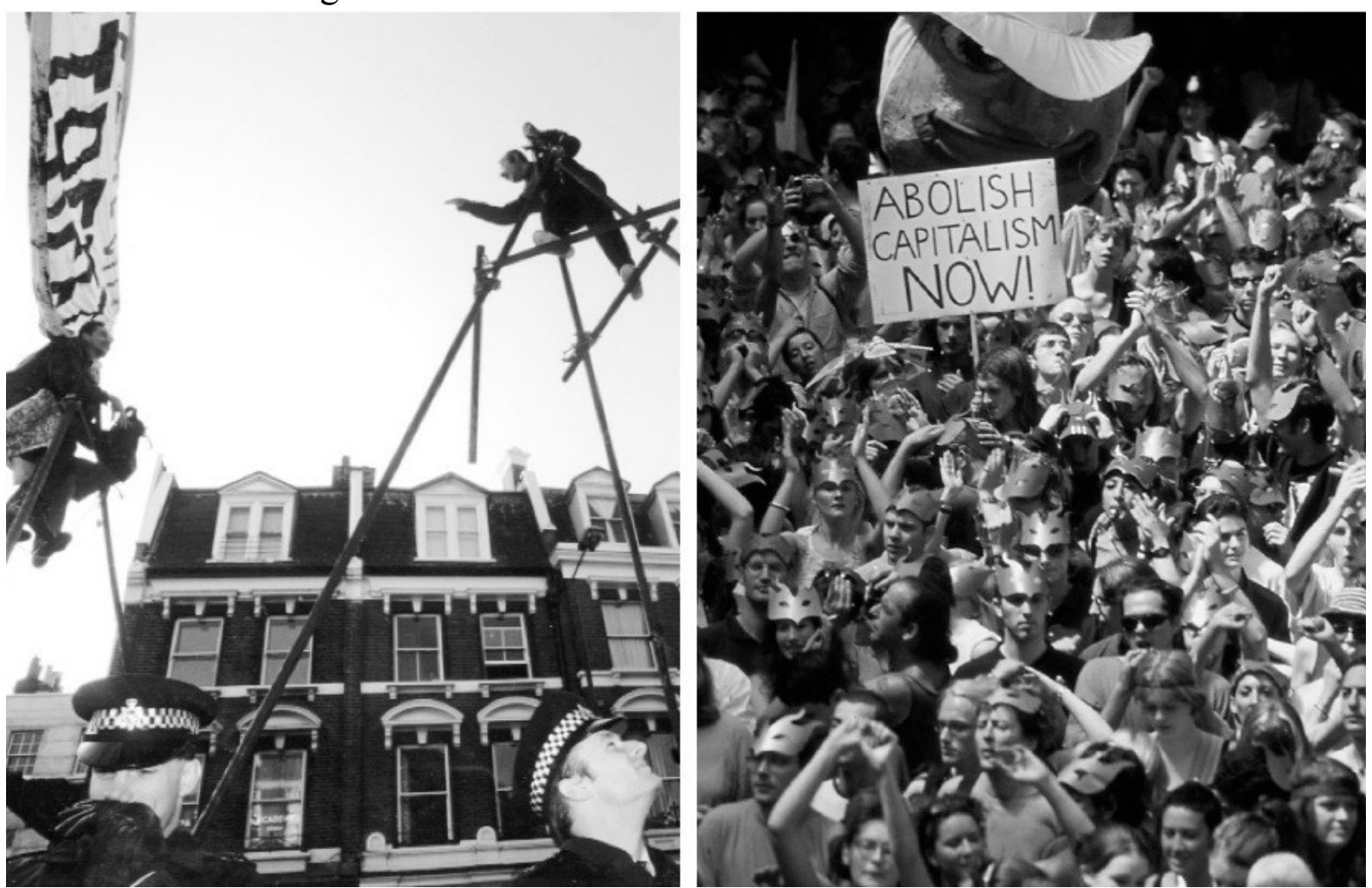

Figura 2: Esquerda: Estratégia de construção de tripés, utilizada pelo Reclaim the Streets para bloquear o trânsito, Streatham, Reino Unido. Direita: Carnaval contra o capital, 18 de junho de 1999, Londres, Reino Unido.

Se a insurgência zapatista foi paradigmática, e a irreverência e autocrítica do RTS foram o diapasão dos Dias de Ação Global, sua máxima expressão e visibilidade aconteceu no final de 1999. A reunião de cúpula da OMC fora marcada para Seattle, nos dias 30 de novembro, 01, 02 e 03 de dezembro. A chamada "rodada do milênio" da organização trazia uma agenda de negociações pouco favoráveis aos países em desenvolvimento. Os protestos durante estes dias, a exemplo do J18, foram globais. $\mathrm{Na}$

\footnotetext{
53 Os textos são "Give up activism" e "June $18^{\text {th }}$ - If I can dance it's not my revolution?" assinados pelos codinomes Andrew X e G. Lancaster. Além desses textos, várias outras reflexões críticas sobre o J18 podem ser acessadas em http://www.afed.org.uk/online/j18/index.html
} 
cidade de Seattle, especificamente, a rede de resistência ao capitalismo obteve um enorme êxito ${ }^{54}$. Os protestos demonstraram a convergência de lutas diversas: "grupos anteriormente considerados em oposição uns aos outros - sindicalistas e ambientalistas, grupos religiosos e anarquistas, e assim por diante - agiram conjuntamente sem qualquer estrutura central e unificadora que subordinasse ou pusesse de lado suas divergências" ${ }^{55}$. O sucesso dos protestos em Seattle foi devido, em parte, à estratégia de bloqueio do acesso ao local do encontro - ativistas realizaram "correntes humanas" que impediram as delegações de se deslocarem pela cidade. Ortellado, no entanto, considera que mais eficiente do que estes bloqueios, foi a ação de "oposição diplomática" 56 , dentro da OMC, de delegações que tinham seus interesses ameaçados na "rodada do milênio". As imagens dramáticas da batalha travada nas ruas, no entanto, sobrepujaram estas medidas diplomáticas. "Os efeitos advindos da força simbólica [de Seattle] (...) foram permanentes. Sem Seattle, dificilmente o movimento teria se espalhado no mundo inteiro com tanta velocidade e intensidade" 57 . Esta mesma consequência de disseminação é apontada por Paul Kingsnorth: "Se não fosse pela 'Batalha de Seattle', nenhum de nós estaria falando sobre globalização da mesma maneira; não é exagero dizer que o mundo não seria exatamente o mesmo. Se a insurreição zapatista foi a primeira revolução pós-moderna, Seattle foi o primeiro protesto de rua pós-moderno" $" 58$.

É preciso ressaltar duas características para entender a dimensão simbólica de Seattle. Primeiro, a atuação do Black Bloc. Mais do que um grupo ou um coletivo, o Black Bloc é uma estratégia de livre adesão. Os manifestantes, em geral de orientação anarquista, que adotam esta estratégia vestem-se de preto e costumam ter o rosto coberto. Durante os protestos, os BB atacam "alvos simbólicos do capital”, destruindo

\footnotetext{
$54 \quad$ Há um vasto material disponível tanto na internet quanto em livros, revistas, jornais e zines sobre os protestos em Seattle. Além disso, dois filmes a este respeito integram o material de referência deste trabalho: o documentário This is what democracy look like (2000), dirigido por Jill Friedberg e Rick Rowley e o ficcional "baseados em fatos reais" Battle in Seattle (2007), dirigido por Stuart Towsend.

55 HARDT e NEGRI, op. cit., p. 281.

56 ORTELLADO, op. cit., p. 26.

$57 \quad$ Ibid. p. 11.

58 KINGSNORTH, op. cit., p. 71.
} 
propriedade de lojas multinacionais, postos de gasolina, shopping centers, redes de supermercados, concessionárias de automóveis, cadeias de fast food e empresas-ícone do capitalismo, como bancos e instituições financeiras. Além disso, costumam construir barricadas com latas, paus, pneus, blocos de concreto, etc e responder aos ataques da polícia com pedras e coquetéis Molotov. Para eles, "a propriedade privada principalmente a propriedade privada corporativa - é em si própria muito mais violenta do que qualquer ação que possa ser tomada contra ela" ${ }^{59}$. Os BB denunciam a violência intrínseca do capitalismo, e consideram que as vitrines e fachadas quebradas em Seattle representam "feitiços quebrados" - feitiços das corporações "para nos embalar no esquecimento de todas as violências cometidas em nome do direito de propriedade privada e de todo potencial de uma sociedade sem ela" ${ }^{60}$.

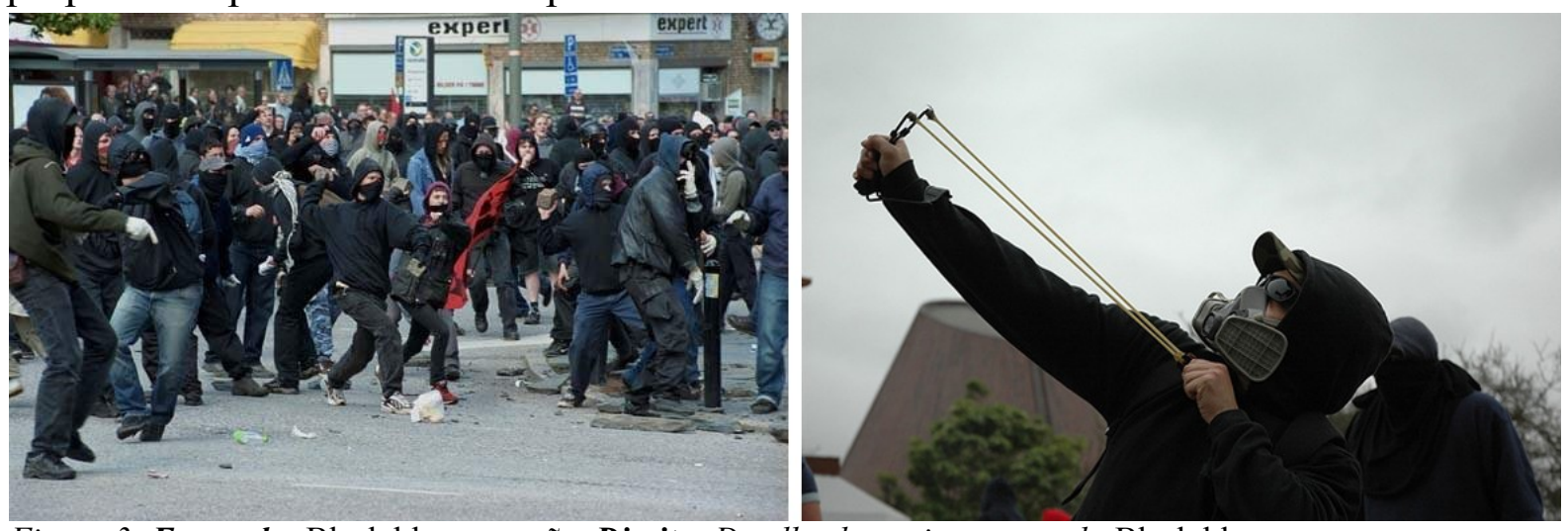

Figura 3: Esquerda: Black bloc em ação. Direita: Detalhe de um integrante do Black bloc.

Sem dúvida, a estratégia do BB alça a prática de protesto a uma radicalidade diferente, com reações também radicais. Por um lado, instaura uma discussão recorrente na rede de ativismo político contemporâneo que é a oposição entre violência e não-violência, intimamente associada a um outro binômio que opõe ação direta e ação simbólica. Os manifestantes "pacifistas" tendem a evitar o confronto com a polícia (diferentemente do BB), e a restringir suas ações a práticas mais "toleradas", como as clássicas manifestações-desfile que são perfeitamente assimiladas pelo poder. Os Black Blocs, pelo contrário,

praticam uma desobediência civil ativa e a ação direta, afastando assim a política do teatro virtual perfeitamente domesticado, dentro do qual [a manifestação política tradicional] permanece encerrada. (...) Os BB não se

LUDD, op. cit., p. 63.

Ibid. p. 64. 
contentam com simples desfiles contestatórios, certamente importantes pela sua carga simbólica, mas incapazes de verdadeiramente sacudir a ordem das coisas $^{61}$.

"Sacudir a ordem das coisas", na sociedade do espetáculo ou na economia biopolítica, significa ser capaz de produzir imagens potentes o suficiente para forçar uma reação por parte da “opinião pública”. Se a oposição diplomática das delegações dos países desfavorecidos na rodada do milênio não cria uma imagem suficientemente boa para a capa de um jornal de circulação massiva, e se o bloqueio do acesso ao local do encontro por ativistas pacifistas cria uma imagem apenas razoável, ativistas mascarados vestindo negro, destruindo vitrines e logomarcas de multinacionais atraíram as lentes da imprensa mundial.

A vasta maioria dos manifestantes [em Seattle], como se sabe, era inteiramente pacífica e mesmo festiva. Os atos mais graves de violência envolviam ataques a propriedades, como a destruição de vitrines de corporações globais simbólicas como McDonald's e o Starbucks. (...) Muitos manifestantes têm se queixado de que a violência de uns poucos incita a polícia, monopoliza as manchetes e eclipsa as mensagens de muitos, além de criar divisões entre os manifestantes. Isto certamente é verdade, mas devemos reconhecer também que, infelizmente, os meios de comunicação voltam sua atenção para os protestos por causa da violência. Sem violência, eles não têm matéria. Existe uma espécie de cumplicidade objetiva entre a mídia e os pequenos grupos de manifestantes que destroem propriedades e procuram entrar em confronto com a polícia. ${ }^{62}$

Esta cumplicidade objetiva entre mídia e manifestantes fica mais evidente no relato crítico de José Chrispiniano:

De repente, alguém descobria um "alvo capitalista" e jogava uma pedra. Aí se juntavam mascarados e jogavam mais algumas pedras. (...) Os manifestantes ali não recusavam sair em fotos. Muito pelo contrário. Às vezes, repetiam seus atos para dar mais uma chance aos fotógrafos. (...) É muito mais simples para editorialistas a milhares de quilômetros de distância, antipáticos a qualquer tipo de protesto, tomar a minoria ruidosa pelo todo e discutir o assunto como um simples caso de hooligans, violência juvenil, um bando de jovens que não sabem o que estão falando ou fazendo. ${ }^{63}$

A segunda característica da dimensão simbólica de Seattle está justamente na relação dos protestos com a mídia. Sedenta por imagens vendáveis e espetacularizantes, a grande mídia em Seattle superexpôs os protestos globalmente.

$61 \quad$ Ibid. p. 78.

62 HARDT e NEGRI, op. cit., p. 362.

63 CHRISPINIANO, op. cit., p. 120 - este relato não se refere a Seattle, mas aos protestos de Praga, em setembro do ano seguinte. De qualquer maneira, a discussão sobre a prática dos BB é equivalente. 
Ainda que isto explique, em parte, a disseminação da resistência, apontada por Ortellado e Kingsnorth, a maioria dos manifestantes estava bastante insatisfeita com o noticiário da imprensa corporativa, cujos relatos eles consideravam parciais e distorcidos. Invertendo o processo, os manifestantes decidiram, em vez de "odiar a mídia", "ser a mídia". Durante o encontro da OMC, através de uma estratégia de do-ityourself ("faça você mesmo"), foi criado um centro de mídia independente, a Indymedia. A infra-estrutura era apenas um ponto de encontro e um website ${ }^{64}$, no qual era realizada a transmissão diária de fotos, áudio e vídeo dos protestos, o que permitiu um confronto com a versão "oficial" da imprensa corporativa. O site teve 2 milhões de acessos e se tornou um modelo para a formação de uma "rede global de livrepublicação de notícias, com mais de 150 coletivos de diversos tamanhos operando em 70 países" ${ }^{65}$. Hoje, atua como um coletivo de imprensa independente (no Brasil tem o nome de Centro de Mídia Independente), e cobre uma série de diferentes assuntos por todo o mundo: libertação animal, antimilitarismo, antirracismo, biotecnologia, mudanças climáticas, cultura, ecologia, educação, espaços livres, gênero, globalização, saúde, guerra do Iraque, migração, Palestina, lutas sociais, tecnologia, guerra sobre o terror, movimentos trabalhistas, zapatismo, etc. A autodescrição no site da Indymedia é "uma rede de indivíduos, ativistas e organizações de mídia alternativa e independente, oferecendo cobertura comunitária, não corporativa e não comercial de importantes assuntos sociais e políticos" ${ }^{66}$.

A capacidade da Indymedia de funcionar como pólo produtor de informação e representação para ativismo político contemporâneo e o sucesso das táticas de desobediência civil em Seattle deram força aos dias de Ação Global subsequentes. Foi o caso dos protestos contra a reunião do FMI, em Washington, EUA, em 16 de abril de 2000; contra a reunião do FMI e do Banco Mundial em Praga, Rep. Tcheca, em 26 de setembro de $2000^{67}$; contra a reunião pró-ALCA (Área de Livre-Comércio das

\footnotetext{
64 http://seattle.indymedia.org/

65 FEENEY, Chekov. "Why we need to reclaim the media" in TRAPESE COLLECTIVE. Do it yourself: a handbook for changing the world. Londres: Pluto Press, 2007, p. 240.

66 http://www.midiaindependente.org/

67 Há uma boa cobertura dos protestos de Praga em CHRISPINIANO, op. cit., 2002.
} 
Américas), no Quebec, Canadá, em 20 de abril de 2001; contra a reunião da União Europeia, em Gotemburgo, Suécia, em 14 de junho de 2001; e o cancelamento do encontro do Banco Mundial, que aconteceria em Barcelona, Espanha, no final de junho de 2001, para citar alguns. Também é importante lembrar a realização do I Fórum Social Mundial (FSM), em Porto Alegre, no final de janeiro de 2001.

O Fórum Social Mundial foi concomitante e ideologicamente contraposto ao tradicional Fórum Econômico Mundial em Davos, na Suíça, e surgiu como "espaço aberto de encontro, plural e diversificado, não confessional, não governamental e não partidário que articula de forma descentralizada, em rede, entidades e movimentos engajados em ações concretas, do nível local ao internacional, pela construção de um outro mundo" "68 . Seu já citado lema, "Um Outro Mundo é Possível" atraiu, na primeira edição, a participação de aproximadamente 15 mil pessoas, dentre ativistas, sindicalistas, ecologistas, organizações não-governamentais, partidos de esquerda, e demais membros da sociedade civil delimitados politicamente pela oposição ao neoliberalismo e ao domínio do mundo pelo capital. O FSM não se pretende uma instância deliberativa ou representativa. Não há cargos ou qualquer eleição a ele relacionada. A orientação do Fórum é regida por uma Carta de Princípios, que apenas estabelece marcos comuns de atuação política. Realizado anualmente desde 2001, o FSM

representou um importante ponto de mudança, no qual ativistas começaram a enfatizar alternativas específicas. (...) Mais do que uma conferência, o FSM constitui um processo dinâmico envolvendo a convergência de múltiplas redes, movimentos e organizações. Enquanto a AGP se mantém mais radical, horizontal e libertária, o FSM é um espaço político mais amplo, que inclui tanto os novos movimentos descentralizados e em rede quanto as forças mais hierárquicas da esquerda tradicional. ${ }^{69}$

Apesar do reconhecido mérito do FSM de mobilizar dezenas de milhares de participantes, e apesar da horizontalidade prevista na Carta de Princípios, alguns analistas, como Jeffrey Juris avaliam que no Fórum há "contradições a respeito do

\footnotetext{
68 http://www.forumsocialmundial.org.br

69 JURIS, Jeffrey S. "New Digital Media and Activist Networking within Anti-Corporate Globalization Movements" in INDA, Jonathan Xavier e ROSALDO, Renato (orgs.). The anthropology of globalization. Oxford:Blackwell, 2008, p. 356.
} 
acesso, participação popular e relações hierárquicas" 70. Para Pablo Ortellado, "a estrutura burocrática e elitista [do FSM] conflitou com as novas formas de organização trazidas pelo novo movimento contra a globalização capitalista". Segundo ele, o FSM foi manipulado pela esquerda institucional e pelas ONGs para cooptar a nova rede de resistência e canalizar sua novidade e energia em formas hierárquicas e burocratizadas de política $^{71}$. Opinião parecida é a de Naomi Klein. Comparando a primeira e a terceira edições do FSM, ela lamenta que um evento que se pautava pelo "novo" passou a eleger o "grande" como valor. Diz que, na primeira edição, "se teve uma coisa com a qual a maioria dos delegados concordou (e não foram muitas), foi que os métodos da esquerda tradicional falharam”. Por isso critica a apropriação da força política e simbólica do Fórum pela esquerda institucional. Para Klein, "a política tem menos a ver com acreditar em líderes bem-intencionados do que fortalecer as pessoas para que elas tomem suas próprias decisões; democracia tem de ser menos representativa e mais participativa"72. De uma forma geral, essas críticas sugerem que o Fórum (pelo menos o comitê responsável pela organização das atividades com conferencistas "de renome") não superou o modelo piramidal da esquerda tradicional. No entanto, há autores como Kingsnorth que enxergam no Fórum justamente o contrário: "As discussões, os debates e as ideias à mostra em Porto Alegre representam (...) algo muito diferente. Uma nova tentativa de um tipo diferente de política, que está lentamente saindo da sombra da esquerda do século XX - retirando a velha mochila ideológica e desembrulhando novas ferramentas. É uma luta difícil; não raro a linguagem e os métodos ainda não estão disponíveis para descrever o que está acontecendo"73. A ativista e pesquisadora Júlia Di Giovanni também concorda com esta inovação metodológica do Fórum: "Mais do que um projeto convergente e alternativo, o Fórum Social cumpre o papel de certificar, num plano intelectual, mais

\footnotetext{
70 JURIS, Jeffrey S. Networking futures - the movements against corporate globalization. Durham: Duke University Press, 2008. p. 255.

71 ORTELLADO, Pablo. “Whose Movement?” Disponível em http://www.nadir.org/nadir/initiativ/ agp/free/wsf/whosemovement.htm - Acesso em 10 de junho de 2009.

72 KLEIN, Naomi. "What Happened with the New Left? - The Hijacking of the WSF". Disponível em http://www.nadir.org/nadir/initiativ/agp/free/wsf/naomiklein.htm - Acesso em 10 de junho de 2009.

73 KINGSNORTH, op. cit., p. 232.
} 
sistemático e aparentado às formas precedentes dos 'internacionalismos' (de esquerdas partidárias ou redes de organizações não governamentais), a emergência de uma 'onda' de contestação que se manifestava nas ruas de forma ainda irredutível" ${ }^{\text {"74 }}$.

A experiência adquirida pelos ativistas (e, naturalmente, também por aqueles interessados em reprimir as manifestações) desde o J18 completou um ciclo em julho de 2001, quando houve a reunião da cúpula do G8 em Gênova, Itália. Os protestos ao longo do encontro mobilizaram aproximadamente 300 mil pessoas. Da mesma forma que nos Dias de Ação Global anteriores, a pluralidade de origens e de reivindicações dos ativistas era evidente: "A composição dos participantes é muito diversa: sindicatos, ambientalistas, representantes da Igreja, militantes de meia-idade da campanha contra a dívida externa, anarquistas adolescentes, políticos partidaristas e milhares de pessoas não-afiliadas mas apaixonadas. Nenhuma pessoa ou organização é 'responsável' por esse mar de humanidade; ela se moverá quando julgar conveniente" ${ }^{75}$. O governo italiano criou uma "zona vermelha" dentro da cidade, com acesso exclusivo para os participantes da reunião. Fortemente guardada por policiais, a "zona vermelha" impedia que os protestos acontecessem próximo ao local do evento.

Duas ocorrências foram responsáveis por tornar Gênova uma marca definitiva para a rede de resistência ativista contemporânea. A primeira foi a morte do manifestante Carlo Giuliani no dia 20 de julho de 2001. Carlo participava da manifestação na Praça Alimonda e foi atingido na face por um tiro de fuzil do carabiniere $^{76}$ Mario Placanica. Em seguida, o carro dos carabinieri passou duas vezes sobre o corpo de Carlo. Julgado posteriormente, Placanica foi inocentado, com alegação de legítima defesa, já que imagens mostraram Giuliani avançando em direção ao carro com um extintor nas mãos. Ele foi alvejado em frente às câmeras, num momento em que a atenção do mundo estava voltada para Gênova. A esse respeito, escreveu Eugenio Bucci:

\footnotetext{
74 DI GIOVANNI, Júlia Ruiz. Seattle, Praga, Gênova: política antiglobalização pela experiência da ação de rua. Dissertação de mestrado apresentada ao Programa de Pós-Graduação em Antropologia Social da FFLCH - USP, 2007, p. 25-26.

75 Ibid, p. 63.

76 Polícia militar italiana.
} 
O que me incomoda nessa cobertura toda não é o que ela vem mostrando, nem as tintas de que ela se vale, mas exatamente o que ela não mostra e não ilumina. É como se exibir a morte fosse o bastante. Para uma imprensa viciada em imagens de impacto, a cabeça ensangüentada de Carlo Giuliani é o olho do furacão. E basta. O nosso olho - nosso olho de público, nosso olho de jornalistas, tanto faz - fica hipnotizado e não consegue se desprender daí. Não vê o entorno, não estabelece as relações necessárias. Assim, caímos numa inversão: a imagem forte, que nos alerta, serve para nos cegar. As razões menos superficiais nos escapam. ${ }^{77}$

A imagem (que alerta e serve para cegar) de Carlo virou um símbolo irredutível para a rede de ativismo político contemporâneo. Muitas perguntas permanecem sobre o caso, já que as versões relatadas são conflitantes ${ }^{78}$.

A segunda ocorrência foi a invasão da Escola Armando Diaz, que servia de alojamento para jornalistas e ativistas participantes das manifestações, por aproximadamente 200 policiais, no dia 21 de julho. A ação ocorreu à noite, enquanto os ativistas dormiam. Dezenas deles foram surrados, tiveram ossos quebrados, dentes arrancados, crânios abertos. Durante duas horas a polícia permaneceu no alojamento, e os gritos dos manifestantes que apanhavam eram ouvidos do outro lado da rua, na sede da Indymedia. Os policiais levaram 93 pessoas presas para Bolzaneto, nos arredores de Gênova. Lá, elas continuaram sendo torturadas, humilhadas, obrigadas a cantar canções e fazer saudações nazistas. Segundo a polícia, a busca tinha como objetivo apreender "armas" que teriam sido usadas durante as manifestações. Foram encontrados martelos, picaretas e pás. Coincidentemente, no terreno da Escola Armando Diaz havia um canteiro de obras, mas a polícia não revelou onde achou os instrumentos. Foram também achados dois coquetéis molotov, posteriormente reconhecidos por um policial como sendo garrafas que ele já tinha apreendido nas manifestações durante a tarde.

A brutalidade da ação policial em Gênova expressa nestes dois episódios, nos quais a repressão foi exercida com um vigor nunca antes demonstrado, revelou a

\footnotetext{
77 BUCCI, Eugênio. "O olho da gente no olho do furacão". Disponível em http://jbonline.terra.com. br/destaques/g8/g82607olho.html . Acesso em 01 de fevereiro de 2006.

78 Placanica teria dito em entrevista em 2002 que fora usado como bode expiatório. Em 2003, se envolveu com um "suspeito" acidente de carro. HOOPER, John. "Genoa officer in 'suspicious' car crash". The Guardian. 06/08/03. Disponível em http://www.guardian.co.uk/world/2003/aug/06/globalisation.italy Acesso em 20/06/2009. Outra fonte que levanta dúvidas sobre o episó dio é a peça de PARAVIDINO, Fausto. Gênova 01. Texto não publicado.
} 
especialização das forças contrainsurgentes e também uma estratégia de criminalização da resistência. A tentativa da polícia e de parte da mídia de associar a imagem de Carlo Giuliani com o Black Bloc ${ }^{79}$ fez parte de uma fervorosa campanha de demonização do grupo. A estrutura descentralizada e a orientação de livre-adesão do Black Bloc permitiu que nele se infiltrassem policiais, neo-nazistas e hooligans ${ }^{80}$, muitos dos quais responsáveis por um deliberado incitamento de confronto com as forças policiais. $\mathrm{O}$ dramaturgo Fausto Paravidino, apesar de se posicionar claramente em oposição ao Black Bloc, levanta a dúvida sobre a origem dos distúrbios em Gênova:

Em Gênova os Black Bloc eram muito diferentes de como se apresentaram nas outras manifestações. Conseguiram praticamente intervir em todas as "praças temáticas" que não tinham um serviço de ordem interno. Nunca foram parados pela polícia. Alguns deles foram vistos saltando de carros da polícia antes de dar início às devastações. Evidentemente é fácil infiltrar-se em um grupo de indivíduos não organizados. Evidentemente os Black Bloc são muito úteis a quem quiser levantar o nível de violência do combate. ${ }^{81}$

A imagem de vilania atribuída (justa ou injustamente) ao Black Bloc atendeu às expectativas das forças de repressão, da mídia e da opinião pública, ansiosas por um bode expiatório, mas também de parte do movimento de resistência global, que, ao recusar solidariedade com o grupo, reivindicou a legitimidade de um "ativismo pacífico" em oposição ao "terrorismo" dos Blacks, isolando-os como os "manifestantes do mal”. "A primeira estratégia de criminalização em Gênova foi a transmissão de uma imagem de caos generalizado que cobre com uma cortina de fumaça o que está em jogo. A segunda é pôr toda a ação de destruição de propriedade no mesmo saco. A terceira é pôr toda ação de confrontação debaixo da marca 'Black Bloc'. Assim se constrói um mito, o inimigo público" ${ }^{\text {. }}$.

Gênova também representou um marco na história dos Dias de Ação Global porque viu a última participação efetiva de um grupo conhecido como Tute Bianche ("Macacões Brancos"). Eles tinham surgido do movimento italiano de Centros Sociais

\footnotetext{
79 Devidamente desmentida por parentes e familiares de Carlo.

80 Grupo com origem inglesa lembrado mais pelo gosto pelo distúrbio e vandalismo do que pela defesa de uma plataforma política.

81 PARAVIDINO, op. cit., p. 5.

82 LUDD, op. cit., p. 198.
} 
Ocupados do início dos anos 90, e reagiam diretamente à precarização do trabalho promovida pelo neoliberalismo: "Os jovens dos centros sociais começaram a identificar o novo paradigma do trabalho que caracterizava suas experiências: o trabalho móvel, flexível e precário típico do pós-fordismo. No lugar dos tradicionais macacões azuis dos antigos operários de fábrica, esse novo proletariado era representado por macacões brancos" ${ }^{83}$. Alheios à filiação com qualquer partido político e associados com a cultura underground, as primeiras ações dos Tute Bianche eram a centradas na organização de festas rave. Essa vocação festiva, assim como no caso do Reclaim the Streets, contaminou o seu ativismo político.

O Tute Bianche, coletivo italiano movido pelo ideal zapatista, famoso pelo uso de macacões brancos que simbolizam a invisibilidade dos povos marginalizados e por suas técnicas criativas de desobediência civil nos protestos anticapitalistas, considera-se um instrumento de expressão e de resistência que, tal como os nomes múltiplos, pode ser apropriado por qualquer pessoa. "Os Tute Bianche nasceram como uma referência irônica aos fantasmas do conflito urbano e depois se tornaram uma ferramenta, um símbolo e uma identidade aberta tornada disponível ao movimento" ${ }^{84}$.

O sucesso dos Tute Bianche estava ligado ao uso tático de sua indumentária. Eles não se configuravam como grupo, mas como um instrumento: "Todo mundo é livre para vestir um macacão branco, desde que respeite o 'estilo', mesmo que transforme o modo de expressão: recusa pragmática da dicotomia violência/nãoviolência; referência ao zapatismo; rompimento com a experiência do século $\mathrm{XX}$; comprometimento com o terreno simbólico da confrontação". ${ }^{85}$ A superação da citada oposição entre violência e não-violência, entre ação direta e ação simbólica e a teatralidade do humor, da autoderrisão, são exatamente as marcas dos Tute Bianche:

Os Macacões Brancos desenvolveram uma tática (...) conhecida como "violência não-violenta". Rejeitando tanto a forma de abordagem do Black Bloc (destruir o local, atacar a polícia) quanto a dos pacifistas da oposição (recusa em participar de qualquer confronto físico), os Macacões Brancos vestem-se com roupas defensivas feitas de velhos coletes salva-vidas, garrafas de plástico e rolos de borracha. Carregam escudos de plástico e usam velhos capacetes de bicicleta na cabeça. Estão prestes a adotar sua

\footnotetext{
83 HARDT e NEGRI, op. cit., p. 334.

84 MESQUITA, op. cit., p. 57. O trecho entre aspas é uma citação de WU MING. "Tute Bianche: o lado prático da produção de mitos (em tempos catastróficos)". Disponível em: http://www.rizoma.net/interna.php?id=142 \&secao=intervencao

85 HOLMES, op. cit., p. 24.
} 
tática favorita - confronto direto com a polícia e seus cassetetes. Eles se recusam a devolver a agressão, mas estão determinados a repelir, ou romper, as barreiras policiais. Ao vê-los se confrontando com a polícia, temos um quadro nítido de onde vem realmente a violência, e essa é a ideia. ${ }^{86}$
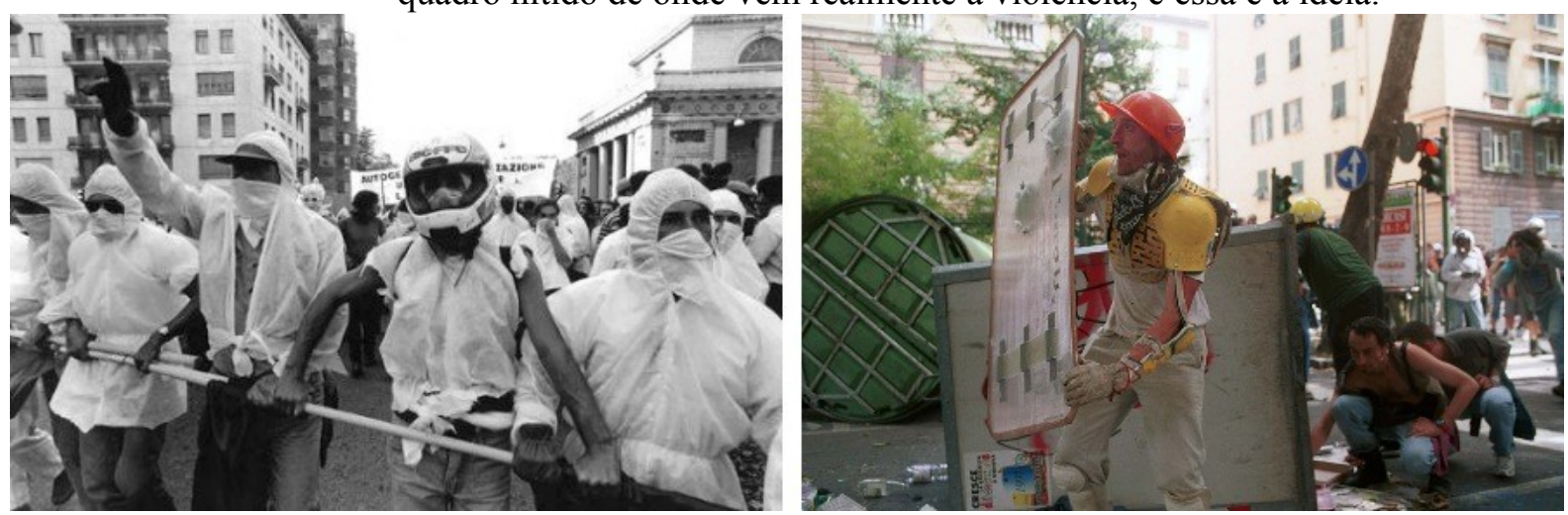

Figura 4: Esquerda: Tute Bianche em marcha, 10 de setembro de 1994, Milão, Itália. Direita: Integrante do Tute Bianche se protegendo das investidas dos carabinieri, julho de 2001, Gênova, Itália.

Roberto Bui, um dos colaboradores do grupo, relata que havia duas tendências de utilização dos macacões brancos. Uma que os consideravam um instrumento aberto, e que, portanto, poderia ser adotado, adaptado e compartilhado. A outra é daqueles que consideravam os Tute Bianche uma identidade, e que, portanto, deveria ser um grupo organizado, homogêneo e arregimentado. Após o revés violento de Gênova, esta segunda tendência foi valorizada, motivada pela consideração de que a repressão policial só foi possível pelo excesso de abertura do movimento ${ }^{87}$. Para Roberto Bui, foi justamente este sectarismo que sepultou o projeto dos Tute Bianche.

Se a repressão em Gênova representou um revés para a força crescente da rede de ativismo político contemporâneo, o golpe que viria após os ataques de 11 de setembro de 2001 seria muito mais severo.

De acordo com Noam Chomsky, os ataques ao World Trade Center e ao Pentágono representaram a primeira ação ofensiva sobre o território dos EUA desde a guerra contra a Inglaterra, em $1812^{88}$. A potência efetiva e simbólica dos acontecimentos levou o compositor Karlheinz Stockhausen a citá-los como "a maior obra de arte de todos os tempos" $" 89$. A polêmica afirmação do compositor alemão

\footnotetext{
$86 \quad$ KINGSNORTH, op. cit., p. 71.

87 BUI, Roberto. "Nenhuma Derrota é Definitiva". Mensagem pessoal recebida por e-mail em 22 de maio de 2008. Disponível em http://fsalvatti.blogspot.com/2008/05/nenhuma-derrota-definitiva.html

88 CHOMSKY, Noam. 11 de setembro. Rio de Janeiro: Bertrand Brasil, 2002. Ele desconsidera os ataques a Pearl Harbor, em dezembro de 1941 por considerar que o Havaí não era território nacional dos Estados Unidos, mas sim uma colônia.

89 A afirmação aconteceu dentro de uma coletiva de imprensa para o Festival de Música de Hamburgo.
} 
demonstra a necessidade de repensar tanto a ação política quanto inclusive os conceitos estéticos à luz de um confronto de poder inteiramente novo. Vernon H. Minor considera que estamos "naturalmente estetizados - e não anestesiados - por eventos horríveis de grande significância histórica" "90, enquanto John Bell reflete sobre a resposta aos ataques, cujo uso "de termos vívidos como 'Eixo do Mal', 'Segurança Doméstica' e 'Armas de Destruição em Massa' são propostos com plena consciência de seus valores semióticos"91. Efetivamente, o confronto posterior ao 11 de setembro, é um conflito de biopoder, "uma forma de governo destinada não apenas a controlar a população, mas a produzir e a reproduzir todos os aspectos da vida social" ${ }^{92}$. Isto está evidente na "Guerra contra o Terror", empreendida desde então (não estou pensando somente nas invasões do Afeganistão e Iraque, mas também na crescente vigilância, não só nos EUA, mas em todo mundo, com a profusão de microcâmeras, detectores de metal, recrudescimento das políticas de migração, etc).

Quando os dirigentes americanos anunciaram sua "guerra ao terrorismo", deixaram claro que deveria estender-se por todo o mundo e por tempo indefinido. Uma guerra para criar ou manter a ordem social não pode ter fim. Envolverá necessariamente o contínuo e ininterrupto exercício do poder e da violência. Não é possível vencer uma guerra dessas, ou, por outra, ela precisa ser vencida diariamente. Assim é que se tornou praticamente impossível distinguir a guerra da atividade policial. ${ }^{93}$

Um mês após o 11 de setembro, o Congresso dos EUA aprovou um conjunto de medidas "antiterroristas", conhecido como "Ato Patriótico", que ampliou os poderes do governo dos EUA sobre os direitos civis dos seus cidadãos. Para o ativismo político, o efeito da adoção destas políticas nitidamente conservadoras, xenófobas e alarmistas foi desmotivador. A consequência imediata foi a criminalização ou "semicriminalização" da militância contrária aos interesses do governo dos EUA (que, por extensão, são os mesmos interesses que norteiam a cartilha neoliberal). Mas, mais

Stockhausen estava falando sobre os limites da criação artística em um período em que eventos dessa magnitude acontecem. Para ele, "em comparação a isso, nós compositores somos nada". Uma boa análise do tema está em MINOR, Vernon Hyde. "What Kind of Tears? 9/11 and the Sublime" Disponível em http://www.bilkent.edu.tr/ jast/Number14/ Minor.htm - Acesso em 10 de julho de 2007.

91 BELL, John. "Performance Studies in an Age of Terror". TDR. vol. 47. Nova York: NYU, Verão 2003. p. 07.

92 HARDT e NEGRI, op. cit., p. 34.

93 Ibid, p. 35. 
grave, o clamor do "Império" por "democracia" como uma bandeira civilizacional contrária à barbárie da $\mathrm{Al}$ Qaeda ${ }^{94}$ reconfigurou o horizonte democrático que a rede de ativismo político contemporâneo propunha de maneira difusa. Obviamente o entendimento de "democracia" nos dois casos é bastante diferente. Mas a histeria por segurança, vigilância e controle - com a mídia ditando a temperatura do medo da opinião pública - fez com que qualquer atitude de dissenso fosse considerada uma ameaça aos valores democráticos.

O paradoxo enfrentado pelo movimento dos movimentos é descrito por Holmes:

Por um lado, a efetividade sem precedentes da ação do 11 de setembro pareceu provar a superioridade do paradigma em rede sobre as hierarquias de comando associadas com o Pentágono e as Torres Gêmeas. Mas ao mesmo tempo, se alguma posição pudesse ser chamada de "oposicional", era a dos fundamentalistas islâmicos. (...) De repente, o movimento de protesto não podia se identificar nem com a forma revolucionária da rede, nem com a recusa oposicional do sistema capitalista. Altas vozes da direita imediatamente aproveitaram a oportunidade para assimilar o movimento com o terrorismo. (...) A dificuldade em situar a resistência em rede ao capitalismo dentro de um espectro maior de forças sociais se tornou enorme - e ainda é, hoje. ${ }^{95}$

Ainda que houvesse essa dificuldade de situação (em especial em uma rede que não se pretende uma unidade identitária e coesa, mas plural e composta por uma miríade de singularidades), a política belicista do governo Bush encontrou ampla resistência por todo o mundo. E não só os coletivos e indivíduos envolvidos nos Dias de Ação Global, mas também outras camadas da opinião pública, pacifistas, e demais opositores do governo Bush fizeram com que no dia 15 de fevereiro de 2003 fosse realizada a maior coordenação de protestos simultâneos da história. Manifestando-se contra a iminente invasão do Iraque, cerca de 30 milhões de pessoas tomaram as ruas em diversas partes do mundo. Mesmo assim, apesar desta expressiva discordância da guerra, a invasão do Iraque ocorreu no dia 20, uma semana depois.

\footnotetext{
94 John Gray tem um excelente ensaio no qual argumenta que o discurso usual sobre a Al Qaeda como uma instituição medieval, bárbara ou pré-moderna, é extremamente equivocado. Ele a considera um subproduto da globalização, e que seu projeto, assim como o do neoliberalismo, o do comunismo ou o do nazismo, é um projeto moderno. GRAY, John. Al Qaeda and what it means to be modern. Londres: Faber e Faber, 2003.

95 HOLMES, op. cit., p. 58.
} 
Desde então, a coordenação de Dias de Ação Global passou por um esgotamento do seu modelo. Se no período entre 1999 e 2001 experimentou um aprimoramento tático e estratégico, e em 2003 atingiu o cume numérico, a rede de ativismo político contemporâneo viveu, desde então, pelo menos em sua escala de articulação global, uma reconfiguração de atuação, objetivos e metodologias.

É certo que o poder da surpresa foi logo perdido, já que todo encontro internacional se tornava um protesto esmagador, e as oligarquias dominantes acharam uma nova coragem para ignorar as expressões democráticas dos cidadãos. Revoltas mais amplas e profundas devem ser inventadas. (...) Para os artistas de um outro mundo, onde quer que eles vivam e seja lá como entendam a si mesmos, deixem que estes momentos sejam hieróglifos do futuro. ${ }^{96}$

Segundo Holmes, "as pessoas perceberam que os movimentos que não se endereçavam a uma instância precisa de poder não atingiriam seus objetivos. Não mudariam a vida, que é a premissa de movimentos sociais. Houve um colapso. [Os movimentos de protesto] cresceram tremendamente e então encolheram tremendamente depois do 15 de fevereiro" ${ }^{97}$. Não podemos falar em desaparecimento da rede, grandes ações continuam acontecendo, com protestos regulares em cada Primeiro de Maio e em cada encontro de instituição supranacional interessada em promover o neoliberalismo. Ainda que os Dias de Ação Global não continuem ocorrendo de forma tão coordenada e avassaladora, o ânimo que os motivou continua latente, em iniciativas menores, mais precisas e difundidas na sociedade, mantendo a criatividade, a radicalidade e a resistência. Conforme sustentarei nos capítulos seguintes, houve uma pulverização desta força que se encontrava concentrada nos Dias de Ação Global, o que levou a modalidades de ativismo político locais e camufladas no cotidiano das pessoas.

A apresentação deste panorama de ações da rede de ativismo político entre 1994 e 2003 obviamente não dá conta da multiplicidade e diversidade de suas manifestações, o que não é a intenção deste trabalho. Antes, espero ter apresentado um contexto suficiente para que se perceba uma prática ativista pautada por valores como

Ibid., p. 77.

97 Entrevista realizada em 10/11/2008. 
a criatividade, a irreverência, o prazer, a horizontalidade e o equilíbrio entre expressão individual e coletiva, que são capacidades subjetivas associadas à cultura e à arte . Negri e Hardt dizem: "é fácil reconhecer a natureza performativa e carnavalesca dos diferentes movimentos de protesto (...). Mesmo quando evidenciam uma feroz combatividade, as manifestações são altamente teatrais, com bonecos gigantes, figurinos, danças, canções humorísticas, cânticos e assim por diante. Em outras palavras, os protestos também são festivais de rua nos quais a indignação dos manifestantes coexiste com sua alegria carnavalesca" ${ }^{98}$. Dentro deste contexto é que a prática do prank pode surgir como uma opção performativa para a rede de ativismo político contemporâneo. 


\section{ENTRE O POLÍTICO E O ESTÉTICO}

Detrás de nosotros estamos ustedes.

Major Ana Maria

Dentro do espectro da rede de ativismo político contemporâneo vários grupos têm escolhido o prank como estratégia, seja para aumentar a visibilidade de suas práticas, para criar contrainformações ou para propor paradigmas alternativos de ação direta. Para o ativismo político, o prank representa a adoção de um alto grau de performatividade, de criatividade e de diversão, sem deixar de expressar um discurso de resistência, no qual convenções sociais são postas em descrédito através da proposição de uma renovação poética contínua. É possível dizer que os pranks visam atingir os alicerces da sociedade. V. Vale salienta as características de humor, sátira e crítica desta prática:

A resistência é extremamente desanimadora se você não puder também se divertir. (...) $\mathrm{O}$ último território sublegal de expressão imaginativa, bem-humorada, criativa e dissidente que ainda resta é sinalizado pelos pranks (...). Os pranks desafiam de maneira não-séria a realidade aceita e os códigos rígidos de comportamento e comunicação. Os pranks habilmente minam a falsidade e a hipocrisia. (...) Os pranks forçam o exercício e o alongamento do músculo mais preguiçoso do corpo, a imaginação. A imaginação é o que cria o futuro. ${ }^{99}$

Considerando diferentes métodos e finalidades, pode-se abordar os pranks em quatro diferentes modalidades. As características destas modalidades não são excludentes, e por vezes um mesmo prank combina traços de mais de uma modalidade. Esta divisão não se pretende exaustiva, ou seja, não pretende dar conta de todas as possibilidades metodológicas ou teleológicas dos pranks. Antes, é uma divisão instrumental que busca identificar características que fazem dos pranks um instrumento atraente para o ativismo político contemporâneo.

- os pranks de situação são aqueles em que são criadas situações artificiais, por vezes conflitantes com as que seriam esperadas de um determinado ambiente ou grupo. Tanto os proponentes das ações, quanto transeuntes e mesmo policiais se

\footnotetext{
99 VALE,V. "Introduction" in Pranks \#2 San Francisco: RE/Search Publications, 2006, p. 4.
} 
veem imersos em acontecimentos alternativos ao usuais, que, por vezes, exigem tomadas de decisões políticas. Podemos dizer, por exemplo, que as festasbloqueios do Reclaim the Streets se encontram nesta modalidade, já que a ocupação "usual" das ruas da cidade (trânsito de carros e pedestres) é reconfigurada em outra dinâmica de ocupação.

- os pranks de simulação visam mimetizar aspectos da realidade de modo a enganar espectadores ou alvos destes pranks. A simulação só é desmascarada como tal no momento em que o prankster julgar apropriado. É a modalidade adotada na "correção de identidade" levada a cabo pelos Yes Men, que se fazem passar por executivos de grandes empresas ou de organismos internacionais para realizar palestras ou dar entrevistas em seus nomes.

- os pranks de comentário "desviam" o significado de informações para transformá-las em contrainformações, criticando, parodiando, satirizando, ironizando ou contradizendo o significado original. Assim, as intervenções sobre outdoors do Billboard Liberation Front ou mesmo a recuperação das histórias em quadrinhos pelos situacionistas são exemplos desta modalidade.

- os pranks de armadilha são ações preparadas para resultar em um prank a posteriori, isto é, em que o alvo dos pranksters só sofre a consequência depois da ação. Algumas das invasões a domicílio do grupo Delinquentes, Inconsequentes e Dementes adota esta modalidade, o que também acontece com os pranks mostrados no filme Edukators ${ }^{100}$.

A partir da descrição e da análise das ações de grupos ativistas, estas modalidades serão pormenorizadas neste e no próximo capítulo. Por ora é preciso salientar que a escolha de cada uma destas modalidades depende dos alvos pretendidos pelos grupos ativistas, e também dos esforços, habilidades e infra-estruturas que eles

100 Título original, Die fetten Jahre sind vorbei, direção de Hans Weingartner, 2004. Dois rapazes e uma garota invadem casas e "redecoram" as residências, empilhando a mobília, colocando eletrodomésticos na geladeira, e deixando bilhetes como "Seus anos de fartura estão acabando" (que é a tradução literal do título em alemão). Os ataques mostrados no filme são muito semelhantes a alguns dos Delinquentes, Inconsequentes e Dementes (descritos em ALMEIDA, Ari. Manual Prático de Delinquência Juvenil . p. 0811. Disponível para download em http://www.delinquente.blogger.com.br/ - Acesso em 15 de junho de 2004), ainda que as ações do grupo curitibano antecedam o filme alemão em dois anos. 
estão dispostos a despender. A diferença de alcance e de visibilidade das modalidades também interfere como critério de escolha.

Uma característica comum a todas as modalidades é que elas trabalham com o inesperado, sempre um elemento de surpresa é transformado em ação. O artista Mark Pauline considera que "um bom prank é divertido e iluminador, (...) eleva a vida para onde a arte deveria estar: na crítica da sociedade para vislumbrar um futuro melhor e mais poético" ${ }^{101}$. De fato, o cômico e o lúdico também são frequentes nas quatro modalidades. Neste sentido encontram eco no "mundo às avessas", a momentânea subversão de poder que Bakhtin atribui à carnavalização das festividades da Idade Média, em sua análise da obra de Rabelais ${ }^{102}$. "O elemento que unifica a diversidade de manifestações carnavalescas e lhes confere a dimensão cósmica é o riso, um riso coletivo que se opõe ao tom sério e à solenidade repressiva da cultura oficial e do poder real e eclesiástico, mas que não se limita a ser negativo e destrutivo, antes projeta o povo-que-ri em liberdade fecunda e regeneradora com a própria natureza" ${ }^{103}$. Esta liberação temporária da ordem estabelecida não é um espetáculo simplesmente assistido pelas pessoas, o coletivo toma parte. O carnaval bakhtininano é uma arma política de suspensão de hierarquias, privilégios e normas.

Os pranks guardam necessariamente um grau de metáfora e de jogo, estão em uma campo em que o simbólico está presente, ainda que este simbólico não se vincule obrigatoriamente ao artístico. Pode-se dizer que o prank se posiciona como um objeto estético para-artístico, ou extra-artístico. Outro elemento que perpassa todas as modalidades é uma certa dose de risco, já que o prank quase sempre flerta com a contrafação, com a ilegalidade ou com a desobediência civil. Como afirmam os Delinquentes, Inconsequentes e Dementes, "se o que você faz, faz impunemente, é porque é inofensivo" 104 .

\footnotetext{
101 PAULINE, Mark in VALE, op. cit., p. 17.

102 BAKHTIN, M. A cultura popular na Idade Média e no Renascimento - o contexto de François Rabelais. São Paulo: Hucitec/ UnB 1999.

103 DUARTE, João Ferreira. "Carnavalização". Disponível em http://www.fcsh.unl.pt/edtl/verbetes/C/ carnavalizacao.htm Acesso em 15 de outubro de 2009.

104 ALMEIDA, op. cit., p. 119.
} 
A atração dos pranks como alternativa de exercício ativista está na supressão de fronteiras entre legalidade e ilegalidade, diversão e protesto, estética e política. Para que esta opção seja posta em prática já existe uma infinidade de táticas e técnicas, que fervilham na rede de ativismo político contemporâneo.

Uma das táticas facilitadoras do prank e que demonstra o parentesco entre a atividade de ativismo político e a atividade artística, em que circulam "singularidade, solidariedade, cooperação e liberdade" ${ }^{105}$, é o desenvolvimento de entidades coletivas. Estes condivíduos, indivíduos compartilhados, "vários corpos em um mesmo Eu" ${ }^{106}$, são nomes que podem ser apropriados por quem queira. Todos podem assinar com aquele nome, que é um múltiplo, formado pela reputação dos atos realizados por outras pessoas sob o mesmo nome. Estas entidades são chamadas por Brian Holmes de fantasmas coletivos ${ }^{107}$, operam no contexto amplo da cultura popular, e são usados como instrumento na luta de classes. Para ele, "o nome múltiplo é um grande recurso artístico-cultural que permite que as pessoas se apropriem de um movimento e coloquem o seu próprio conteúdo, sua própria vontade, sua própria energia, seu próprio desejo" 108 .

Em medidas diferentes, com aproximações também diferentes, são fantasmas coletivos os Tute Bianche, o Black Bloc, o Reclaim the Streets e mesmo o Subcomandante Marcos ${ }^{109}$. Há diversos outros nomes múltiplos, fantasmas coletivos, com individualidade compartilhada no espectro entre arte e ativismo ${ }^{110}$. Como ressalta Stewart Home, "A ideia [de um condivíduo] é criar uma 'situação aberta' na qual

105 HOLMES, op. cit., p. 58.

106 BLISSETT, Luther. Guerrilha Psíquica. São Paulo: Conrad, 2001. Col. Baderna, p. 115.

107 A partir da proposição de Boris Karloff, da Associação de Astronautas Autônomos, no texto " Resisting Zombie Culture", disponível em www.uncarved.org/turb/articles/karloff.htm

108 Entrevista realizada em 10/11/2008.

109 A série de HQ $V$ for Vendetta aproveita também o leitmotif de um fantasma coletivo mascarado. Escrita entre 1982 e 1985 por Alan Moore e ilustrada por David Lloyd, a história foi transposta para o cinema em 2005. Num mundo pós 11 de setembro, apesar do enaltecimento de um herói-terrorista que explode o parlamento britânico causar algum frisson, a mensagem anarquista pasteurizada do filme demonstra a reificação blockbuster do fantasma coletivo.

110 Como Vitoriamario, comunidade anarquista; Karen Eliot, ativista anti- copyright; Mounty Canstin, artista plástico vândalo que fazia intervenções com sangue em peças de museu; Lieutenant Murnau, músico contemporâneo, entre tantos outros. - ver SALVATTI, Fabio. A plagiocombinação como estratégia dramatúrgica na cibercultura. Dissertação de mestrado apresentada ao Programa de Pós-graduação em Teatro do CEART - UDESC, Florianópolis, 2004, p. 17. 
ninguém em particular é responsável. Alguns proponentes do conceito também defendem que isto é uma maneira de analisar praticamente, e botar abaixo, as noções ocidentais de identidade, individualidade, valor e verdade" ${ }^{111}$. Claramente, é uma crítica à mística do indivíduo como propulsor da ação estético-política. Dentro do universo da arte, a opção pelo nome múltiplo significa um posicionamento sobre a propriedade intelectual, valor preponderante em uma economia biopolítica, em que o conhecimento é a maior commodity: "Nomes múltiplos trazem a recusa do direito autoral e propriedade intelectual para o centro da subjetividade dominada pelo ego, numa tentativa de dissolver a função proprietária da assinatura que sempre serviu como uma barreira entre a arte contemplativa, individualista, e formas de expressão coletivas e interativas" ${ }^{112}$. Esta crise da autoria (prenunciada ao longo do século XX, em diversas áreas da vanguarda estética e política ${ }^{113}$ ) é um projeto estético e um projeto político simultaneamente.

A reivindicação do fantasma coletivo também mantém a ideologia do faça você mesmo que distingue a rede de ativismo político contemporâneo das representações partidárias ou sindicais tradicionais. Ao mesmo tempo em que a utilização dos nomes múltiplos é absolutamente singular, manifesta a construção do comum em rede, já que a reputação dos fantasmas coletivos é construída em processo, com a adição e o compartilhamento de ações daqueles que os evocam. "É muito mais interessante abandonar sua subjetividade para ser parte de uma multidão, unir-se a um complexo esforço coletivo que não necessita de sua história pessoal completa" ${ }^{114}$. Assim, a rede pode se mover simultaneamente em várias direções.

\footnotetext{
111 HOME, Stewart in BLISSETT, ob. cit., contracapa.

112 HOLMES, op. cit., p. 178.

113 Ver FOUCAULT, Michel. O que é um autor? Lisboa: Passagens, 1992, e BARTHES, Roland. "A morte do autor" in O rumor da língua. São Paulo: Brasiliense, 1988.

114 HOLMES, Brian. "Estéticas de la Igualdad. Jeroglíficos del Futuro. - Entrevista a Marcelo Expósito" in Desacuerdos \#2. Barcelona: Arteleku, MacBa e Unia, 2005, p. 237.
} 
Tomemos o exemplo de Luther Blissett ${ }^{115}$, um personagem-metodologia. Luther é uma criatura mitológica que opera na guerrilha de comunicação, na psicogeografia, no ativismo anti-copyright, numa radical crítica ao Estado e ao modo de produção capitalista. Qualquer um pode ser Luther Blissett, simplesmente declarando-se parte do projeto e assinando pelo nome coletivo de Luther Blissett. Isso faz com que a reputação desse herói, desse "Robin Hood" da era digital, seja desenvolvida por uma rede de pessoas que acrescentam informações e intervêm subjetivamente em sua biografia. Opera-se uma mitopoese, isto é, a construção de um mito, uma lenda remanipulável constantemente, instrumentada por um "nome multiuso".

O surgimento do nome coletivo foi atribuído a Harry Kipper ${ }^{116}$, um artista inglês que teria proposto o Projeto Luther Blissett (aproveitando o nome de um atacante anglo-jamaicano que jogou pelo time do Milan na temporada de 1983-1984) como estratégia de resistência cultural em 1994. A partir de então desenvolveu-se uma rede indiscriminadamente aberta ao redor da ideia de Luther Blissett. Suas principais ações foram os "pranks de mídia", que adotavam características principalmente das modalidades "pranks de simulação" e "pranks de armadilha". Notícias falsas, mas verossímeis, eram "plantadas" em jornais e logo em seguida assumidas por Blissett. Alguns exemplos:

Na primavera de 1994 começaram a chegar aos jornais de Bolonha uma série de cartas denunciando o aparecimento de entranhas de animais em ônibus, parques públicos e estacionamentos da cidade. Alguns transeuntes testemunharam o "estripamento" de um performer, que arrancou de sua camisa os intestinos de um bezerro, durante a simulação de um ataque epiléptico. Algumas semanas depois, após mais cartas, foram encontrados um cérebro bovino e um coração suíno no meio de uma apresentação de jovens católicos. Os jornalistas batizaram o fenômeno de

\footnotetext{
115 Ver SALVATTI, Fabio "Eu sou ele assim como você é ele assim como você sou eu e nós somos todos juntos - elementos performáticos e subversivos em Luther Blissett" . in MEMÓRIA ABRACE VII - Anais do III Congresso Brasileiro de Pesquisa e Pós-graduação em Artes Cênicas. Associação Brasileira de Pesquisa e Pós-graduação em Artes Cênicas. Florianópolis, 2003; e também a entrevista que fiz com Roberto Bui, um dos participantes originais do Projeto Luther Blissett: SANT'ANNA, e SALVATTI, $o p$. cit.

116 A identidade do próprio Kipper é fantasiosa.
} 
"horrorismo", e páginas dos periódicos locais foram dedicadas ao assunto. No final do verão, Luther Blissett assumiu a autoria das cartas e da distribuição das entranhas, demonstrando o que se pode fazer com alguns selos e um pulinho no açougue.

O artista inglês Harry Kipper desapareceu durante a realização de uma performance em outubro de 1994. Sua intenção era cumprir um trajeto de bicicleta que escrevesse a palavra $A R T$ no mapa da Europa. No final do $T$, contudo, ele se perdera na Bósnia e seus amigos e familiares estavam preocupados. Decidiram publicar um cartaz reportando o desaparecimento, que logo chamou a atenção do programa televisivo $C h i$ la Visto?, especializado em sensacionalizar buscas por pessoas desaparecidas. Uma equipe de jornalistas foi enviada para Bolonha, onde colheu depoimentos de seus amigos, fotos de Kipper, viu seus objetos pessoais, etc. Foram orientados para procurar em Údine, local onde o artista teria sido visto pela última vez. A versão foi confirmada, mais informações foram dadas aos jornalistas, inclusive o endereço londrino de Harry Kipper, para onde os jornalistas também se dirigiram. Poucos instantes antes do programa entrar no ar a farsa foi desfeita e Luther Blissett assumiu a ação em uma conferência na imprensa.

A cidade de Viterbo foi assolada entre 1996 e 1997 por uma legião de satanistas. A polícia local e a imprensa foram alertadas por telefonemas anônimos que as conduziram a restos de missas negras: velas, pentagramas, galos pretos e bugigangas satânicas. Após a publicação nos jornais, vários cidadãos enviaram testemunhos que confirmavam os indícios. Fundou-se um Comitê para a Salvaguarda da Moral, caçadores de satanistas que adquiriram espaço na imprensa. Com o pânico crescente, a Igreja foi forçada a se pronunciar contra as atividades obscuras na cidade. Em seguida, chegou à redação dos telejornais uma fita de vídeo que documentava um ritual. A imagem era de péssima qualidade, podia se ver ao longe um grupo de pessoas entoando um mantra e uma moça gritando. Todos os telejornais dedicaram amplo espaço à denúncia e exibiram o vídeo. Uma semana depois, a emissora $T V 7$ recebeu a versão integral da mesma gravação. Nesta, o cinegrafista se aproximava das figuras encapuzadas que participavam da missa negra: de repente elas arrancavam os capuzes 
e dançavam uma desenfreada tarantela ao redor de um cartaz de Luther Blissett. Desde as cartas, passando pela fundação do Comitê, até o vídeo, tudo fora forjado pelo coletivo $^{117}$.

Alguns participantes do grupo proponente do Projeto Luther Blissett fundaram, em 2000, a Wu Ming Foundation, um coletivo de escritores empenhados no compartilhamento da criação e na luta anti-copyright. Em chinês, "wu ming" significa "anônimo" ou "sem nome". Além de publicar romances escritos em grupo (como $Q-$ O Caçador de Hereges, 54, Manituana, etc. ${ }^{118}$ ), cada um dos cinco integrantes se dedica a projetos solo. Integrantes do Projeto Luther Blissett, já adotando o nome Wu Ming, colaboraram com os Tute Bianche nos protestos em Gênova. Seu papel narrativo naquela ocasião foi a criação mitopoética de uma "história compartilhada", uma espécie de poema-épico que ligava os levantes de oprimidos desde o século XIV até a atualidade. Aproveitava uma frase do Subcomandante Marcos "nós somos novos, mas somos os mesmos de antes" ${ }^{119}$.

Blissett e Marcos oferecem dois tratamentos distintos para a prática do prank. Seus projetos, métodos e trajetórias são bastante diferentes. Enquanto o primeiro adotava prioritariamente os pranks de armadilha, propondo um jogo de escondeesconde com a mídia, golpeando-a exatamente em seu calcanhar de Aquiles; o segundo rompe o binômio visibilidade/invisibilidade da representação política ao diluir sua identidade e compartilhar seu nome, numa intrincada relação entre existência física una (afinal, Marcos é um indivíduo) e sua existência potencial plural ${ }^{120}$, em um claro exemplo de prank de simulação. "O pasamontañas (...) deixou de ser um instrumento de pura clandestinidade ou uma imagem ameaçadora para converter-se na representação fortemente visível de uma identidade múltipla e aberta que não aceita nem ser silenciada nem ser codificada pelos discursos de poder" ${ }^{121}$.

\footnotetext{
117 Estes e outros pranks estão descritos em www.lutherblissett.net, ver também www.wumingfoundation.com $118 Q$ e 54 foram publicados no Brasil pela Conrad Editora. O primeiro ainda sob o nome Luther Blissett.

119 SANT'ANNA e SALVATTI, op. cit.

120 Uma das urgências do governo mexicano foi "determinar a identidade" de Marcos. Em fevereiro de 1995, o governo declarou que Marcos era Rafael Sebastián Guillén Vicente, um professor da Universidade Autônoma Metropolitana, na Cidade do México.

121 HOLMES in Desacuerdos \#2 op. cit., p. 241.
} 

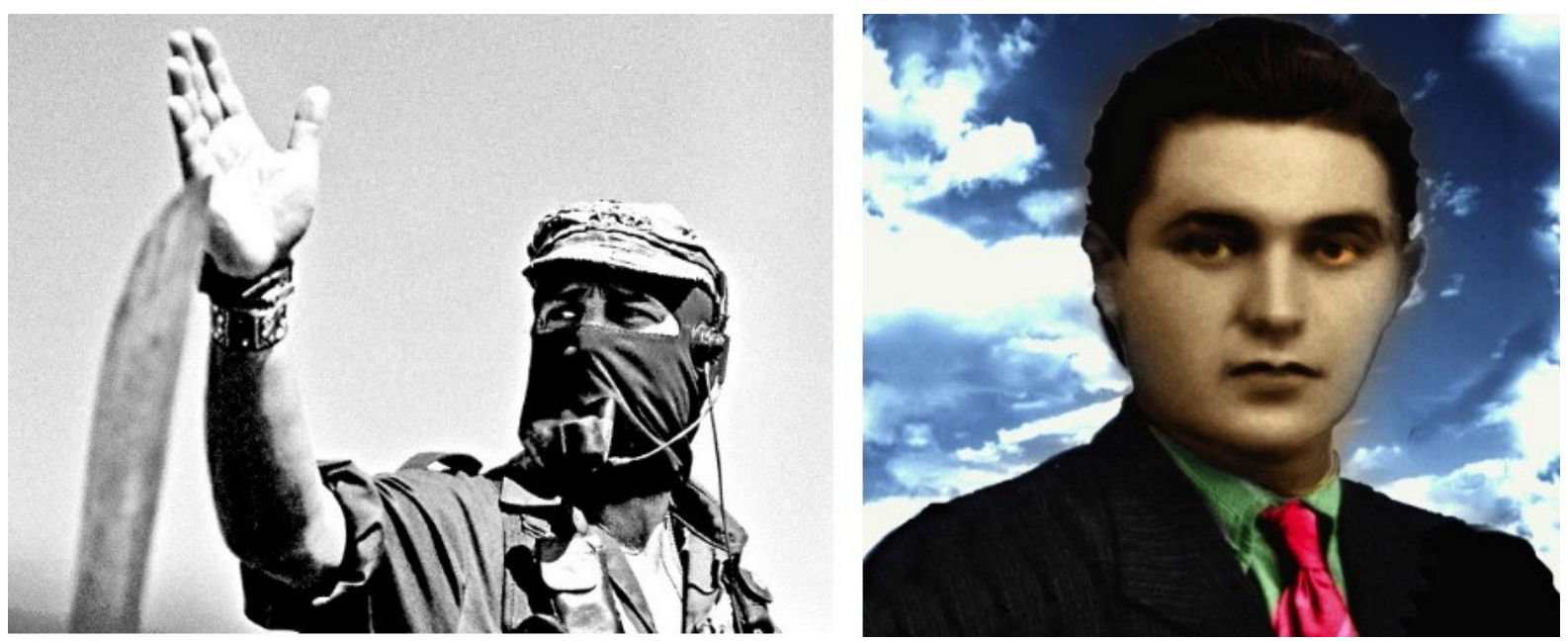

Figura 5: Esquerda: Subcomandante Marcos, abril de 2006, sudeste do México. Direita: Rosto fictício de Luther Blissett, composto por fragmentos de imagens de outras faces.

Mesmo com as diferenças entre Blissett e Marcos, a construção que ambos representam de um mito aberto, elástico e redefinível representou uma poderosa arma para a rede de resistência ao capitalismo contemporâneo. Há uma enorme quantidade de combustível inflamável, de empoderamento, sob a ideia de um condivíduo. Blissett afirma que se todos são Blissett, todos podem ser qualquer coisa, "todos os homens que repetem uma linha de Shakespeare são William Shakespeare”.

O Black Bloc, o Reclaim the Streets e os Tute Bianche, ainda que não promovam sua reputação ao redor de um indivíduo, de uma pessoa singular (real ou imaginária), também podem ser considerados fantasmas coletivos pela construção aberta das suas ações, quando se oferecem como metodologia através da qual um manifestante individual pode orientar suas ações de protesto. A diferença é que a existência destes fica sendo necessariamente grupal, são fantasmas que só existem "em bloco" e por tempo determinado (a duração de determinado protesto), enquanto Blissett e Marcos podem existir "em células" e perenemente. Os diferentes tratamentos dado ao prank merecem considerações. Sem dúvida, como tática, os três grupos adotam ações que são irreverentes e desautorizadoras, condições fundamentais do prank. No entanto, não podemos pensar que ações típicas do Black Bloc, como a destruição da fachada de uma cadeia multinacional de fast food ou o confronto direto com policiais, reúnam predominantemente as características simbólicas e artísticas do prank. É claro que estas ações não têm uma "diretividade pura", o que seria 
impensável ${ }^{122}$. Necessariamente elas apresentam algum grau de metáfora, ou, antes, de metonímia - as vitrines quebradas não são só as vitrines quebradas, mas a já citada "quebra de um feitiço do capitalismo". Isto representa, sem dúvida, um alto grau de risco para os agentes. No entanto, o esforço anedótico, humorístico, o caráter de jogo, é menos privilegiado. Nas festas do Reclaim the Streets e no enfrentamento dos Tute Bianche, por outro lado, fica mais evidente perceber que estão contempladas as características dos pranks de situação ${ }^{123}$. Sobre o RTS, John Jordan afirmou:

A rua se tornou palco para um teatro ritual participativo: ritual por causa da sua eficácia, que produz efeitos reais a partir de causas simbólicas; participativo porque a festa de rua não tem divisão entre o performer e o público, é criada por e para todo mundo, evita qualquer mediação, é experienciada no momento imediato por todos, num espírito de camaradagem subversiva cara a cara. Quando a festa de rua está em seu auge - quando milhares de pessoas tomam uma rua movimentada e a declaram "aberta"; quando música, gargalhadas e cantos tomam os sons dos carros; quando a fúria das ruas se torna a festa das ruas; quando o cinza-concreto é coberto pelas cores vivas de um festival - cumpre-se o desejo de Lautréamont: "A poesia deve ser feita por todos. Não por um." 124

Quando há uma força policial armada com cassetetes, gás lacrimogênio, spray de pimenta, escudos, capacetes, bombas de efeito moral enfrentando um grupo vestindo almofadas, capacetes de skate, óculos de mergulho, espadas de borracha e pistolas d'água (para "liquidar o capitalismo"), é claro que o confronto se dá no plano da alegoria, uma situação é criada - a encenação de uma batalha. Mas, entretanto, é também efetivamente uma batalha: os manifestantes levam literalmente cassetadas e gás em seus olhos.

A característica dual deste tipo de ativismo, ao mesmo tempo a coisa e a simbolização da coisa, é chamada por Brian Holmes de representação direta, um conceito dialético entre a redutiva polarização "ação direta" versus "ação simbólica" ${ }^{25}$. O termo surgiu em 2000, durante uma oficina que ele ministrava em

122 Brian Holmes comenta da seguinte maneira o paradoxo entre diretividade e simbologia das ações: "hoje em dia a ação direta pode se tornar simbólica, porque a insistência das pessoas em mudanças concretas é, em si mesma, paradoxalmente, simbólica". Ver entrevista em anexo.

123 Ainda que o paradoxo entre diretividade e simbologia também não se resolva facilmente.

124 JORDAN in MCKAY, op. cit., p. 141-142.

125 John Jordan enxerga na ação direta o mesmo potencial lúdico e irreverente que Holmes vai atribuir à representação direta: “Ação direta é a performance onde o poético e o pragmático dão as mãos. (...) É, por sua natureza, profundamente teatral e fundamentalmente política. (...) Ação direta é praxe, catarse e imagem em um só pacote. A ação direta introduz o conceito de jogo no mundo previsível e cinza da 
Barcelona, com o sugestivo título de "A ação direta como uma das Belas Artes". "[A representação direta] é uma provocação contra a velha ideia anarcosituacionista de que toda ação simbólica se encontra alienada sob o espetáculo unificado da representação política e o imaginário comercial, de tal maneira que a única resposta só poderia consistir em um ato secreto, denso, invisível e rigorosamente material." ${ }^{126}$ A representação direta tem uma motivação faça você mesmo: é o uso instrumental da representação nas mãos dos próprios ativistas; é a capacidade de criar táticas (como os fantasmas coletivos, por exemplo) para a autoexpressão e auto-organização de grupos diversos que as possam usar para reclamar o comum. Esta emancipação da expressividade estética dos ativistas tem caráter duplo de ferramenta e signo.

Neste caminho contíguo de expressão estética e política, a representação direta evidencia a proximidade entre os pranks e determinadas expressões das artes modernas e contemporâneas. Vale afirma que "um exame casual da arte do século XX revela uma galáxia negligenciada de eventos-pranks brilhantes, que alteraram para sempre o caminho da atividade criativa, como as Senhoritas de Avignon, de Picasso (uma pintura de prostitutas), a Fonte de Duchamp (um urinol que ele intitulou 'escultura'), e o sucesso de Warhol na comercialização de pinturas retratando acidentes de carro sangrentos como 'alta arte"' ${ }^{127}$. De fato, ao longo dos últimos cem anos as características de ruptura, derrisão e jogo presentes nos pranks têm sido recorrentes em determinadas linhagens artísticas. A autoexpressividade que identifica a representação direta esboça-se na arte conceitual e no dadá, fica evidente na body art, e, sobretudo nos happenings e na performance art, nos quais é constatado um esforço de deslocar o sentido criativo da obra para o criador. "A ação do artista sustenta-se como mensagem estética por si mesma e o seu registro residual ou documental representa um

política. (...) É extremamente divertido, um jogo fantástico: jogo de gato-e-rato, ou antes, de Davi e Golias". Ibid. p. 132-133. No entanto, é necessário observar que o texto de Jordan, escrito em 1998 parece, primeiro, ter um caráter de divulgação aliciadora. Sua função é ambígua - ao mesmo tempo um relato e um convite à ação. Em segundo lugar, o texto é anterior aos eventos em Seattle e Gênova, nos quais metodologias mais "diretas" e metodologias mais "simbólicas" de protesto coexistiram, nem sempre de maneira tranquila. Podemos considerar que Jordan priorizaria as características poéticas propostas pela representação direta em detrimento da ação direta, o que fica evidente se substituirmos um termo pelo outro na leitura de seu texto.

126 HOLMES in Desacuerdos \#2, op. cit., p. 225.

127 VALE e JUNO, in RE/Search \#11, op. cit., p. 04. 
epifenômeno" 128 . Ao colocar o artista no centro significante da arte, a "atitude" de seu corpo e a enunciação de seus conceitos inauguraram um outro paradigma de percepção do sistema de arte, cujas fronteiras foram forçadas de maneira crítica. Prova disso é o constante uso de ironia, sarcasmo e iconoclastia por artistas que fizeram parte desta tradição artística citada.

Brian Holmes reforça a transgressão de linguagem que a arte conceitual realiza sobre o sistema de arte consignado aos museus. "A arte conceitual pode ser definida não apenas pela recusa do objeto comodificado e do sistema de arte especializado, mas como um sinal ativo apontado para o mundo externo, concebido como um campo expandido para práticas experimentais de intimidade, expressão e colaboração, de fato, para a transformação da realidade social" ${ }^{129}$. A recusa da mercantilização do objeto artístico, a autoexpressividade e o questionamento das fronteiras estéticas são características muito fortes dos happenings e da performance art. Renato Cohen reconhece na radicalidade estética um parentesco com a radicalidade ideológica da contracultura, "a performance é basicamente uma linguagem de experimentação, sem compromissos com a mídia, nem com uma expectativa de público e nem com uma ideologia engajada. Ideologicamente falando, existe uma identificação com o anarquismo que resgata a liberdade na criação, esta a força motriz da arte" ${ }^{130}$. Isto revela na performance art um parâmetro de ruptura, de combate, de militância. Por isso que, conceitualmente, a performance art e o happening se aproximam dos pranks e da rede de ativismo político contemporâneo, porque também radicalizam seus métodos e críticas.

Outras características demonstram a convergência destes campos. Uma delas é a dificuldade de circunscrição em categorias estáveis, isto porque tanto nos pranks quanto na performance art e nos happenings há uma valorização do processo, no qual um alto grau de imprevisibilidade e instabilidade é instaurado. A respeito do

\footnotetext{
128 MATUCK, Artur. "Prefácio" de COHEN, Renato. Performance como linguagem. São Paulo: Perspectiva, 1989.

129 HOLMES, op. cit., p. 47.

130 COHEN, op. cit., p. 44.
} 
happening, Cohen afirma que "interessa mais o processo, o rito, a interação e menos o resultado estético final. (...) No happening, o limite entre o ficcional e o real é muito tênue e nesse sentido a convenção que sustenta a representação é constantemente rompida"131. Priorizar o processo e o rito significa dar maior importância à vivência, e, por isso, à criação do comum, da experiência compartilhada. Isto explica porque tanto na performance art e happenings quanto nos pranks há uma recusa ao papel do especialista, possibilitando uma participação mais horizontal, "vivencial" e inclusiva nos processos. São características que Jorge Glusberg acrescenta ao happening: "Articula sonhos e atitudes coletivas. Não é abstrato nem figurativo, não é trágico nem cômico. Renova-se em cada ocasião. Toda pessoa presente a um happening participa dele. É o fím da noção de atores e público. Num happening, pode-se mudar de 'estado' à vontade. Cada um no seu tempo e ritmo" ${ }^{132}$. Se não há circunscrição estável de categorias e nem especialização dos agentes, ou seja, se todos são atuantes e observadores simultaneamente ${ }^{133}$, podemos afirmar que, quando adota opções performáticas como o prank, a rede de ativismo político contemporâneo propõe uma transcendência do limite entre política e vida, assim como a performance art e o happening propõem uma transcendência do limite entre arte e vida. É especialmente aí que se evidencia a orientação faça você mesmo: na adoção de estratégias como os pranks não existe mediação, a expressividade política e estética não é delegada a ninguém, depende de uma proatividade que é, ao mesmo tempo, individual e em rede. A emancipação representacional característica dos pranks concentra e cataliza a potência de expressividade simbioticamente estética e política de uma rede de agentes críticos ansiosa por instaurar processos criativos de mudança social.

\footnotetext{
Ibid. p. 132-133.

132 GLUSBERG, Jorge. A arte da performance. São Paulo: Perspectiva, 2005, p. 34.

133 Joseph Beuys é certamente um artista fundamental nesta perspectiva de interpenetração das práticas artísticas e políticas. Ao propor que "todo mundo é um artista”, não só democratiza a prática artística, mas eleva-a a uma prática cidadã-estética, que resulta na formulação de suas "esculturas sociais", na qual os cidadãos somos esteticamente responsáveis pela construção de nossa práxis social, em um processo contínuo e engajado. "A intenção de Beuys foi definir a arte e a criatividade como as únicas ferramentas úteis para alcançar a revolução social. Desde que alguém, em suas ações, tente moldar ou remoldar a humanidade, poderia então, na visão de Beuys, ser considerado artista". JUNG, Jenny. "Performing a mob" Disponível em http://www.fdcw.org/0708/jung2/ - Acesso em 05 de janeiro de 2010.
} 
Ao convocarmos teóricos que ampliam a compreensão de performance para além do campo exclusivo da história e da prática artísticas, abrimos outras possibilidades de abordagem para os pranks. Richard Schechner aponta quatro parâmetros que balizam o objeto de investigação do que ele batizou de "estudos de performance":

Performances são ações. Como disciplina, os estudos da performance tratam muito seriamente das ações de quatro maneiras. Primeira, o comportamento é "objeto de estudo" dos estudos da performance. (...) Segunda, a prática artística é uma grande parte do projeto dos estudos da performance. (...) Terceira, o trabalho de campo como "observador participante" é um método priorizado, adaptado da antropologia e colocado em novos usos. (...) Quarta, frequentemente os estudos da performance estão ativamente envolvidos em práticas sociais. ${ }^{134}$

As balizas de Schechner sugerem um amplo leque de atividades humanas ${ }^{135}$, das quais a arte é uma parte importante, mas não a única. Para o autor, nós performamos nossa própria existência, em especial a existência social. Mesmo que possamos relativizar esta colocação, situando-a em um contexto que valoriza características antropológicas do fenômeno da performance, ainda assim a afirmação detecta um transbordamento da experiência performativa para além do "propriamente dito" artístico, em direção a um campo de estudos plural e antiautoritário, aberto a experiências marginais, minoritárias e subversivas, de forma a incluir todos os domínios da cultura. As raízes dos "estudos de performance" incluem teatro, ciências sociais, estudos feministas e queer, estudos pós-colonialistas, estudos pósestruturalistas, performances experimentais, interações entre filosofia ocidental e oriental, estética do cotidiano e cultura pop. Os estudos de performance não são um sistema unitário, com hierarquias estabelecidas, já que, para eles, nenhuma teoria da performance pode ser universal. Na sua investigação sobre as ações humanas, os estudos da performance relevam a multiplicidade da interpretação dos eventos, na qual qualquer interpretação deve ser posta em contexto, responder a diferentes perspectivas.

\footnotetext{
134 SCHECHNER, op. cit., p. 1-2.

135 Schechner afirma que a 'performance deve ser construída em um 'largo espectro' ou ' continuum' de ações humanas, desde rituais, jogos, esportes, entretenimentos, artes performativas (teatro, dança, música), e performances cotidianas que decretam papéis sociais, profissionais, de gênero, raça e classe; até atividades de cura (do xamanismo à cirurgia), a mídia e a internet” (Ibid. p. 2).
} 
Vale dizer que qualquer visão ou interpretação da realidade sob os estudos da performance é subjetiva e parcial. A professora Diana Taylor considera que "ainda que a-histórico em muitas de suas práticas, os estudos da performance podem nos permitir o engajamento em uma análise histórica sustentada de práticas de performance" ${ }^{136}$. Para Taylor, a significância dos estudos da performance como instrumento de análise histórica é ressaltada por eles tratarem de transgressões de estruturas sociais e de subversões de funções normativas.

O projeto de Jon Mckenzie é distinto do de Schechner, pois pretende formular um princípio geral que possa ser adequado para abordar os três paradigmas que ele adota para a performance: o organizacional, o tecnológico e o cultural. Um dos argumentos centrais de Mckenzie é que a performance deve ser entendida como um estrato emergente de poder e conhecimento: "a performance será para os séculos XX e XXI o que a disciplina foi para os séculos XVIII e XIX, ou seja, uma formação ontohistórica de poder e conhecimento" ${ }^{137}$. O parâmetro de pesquisa do paradigma cultural da performance corresponderia, para Mckenzie, aos estudos da performance ${ }^{138}$. Ele apresenta uma trajetória crítica da formação do campo de pesquisa dos estudos da performance, ressaltando a verve política que diversos autores imprimem aos objetos estudados. Janelle Reinelt e Joseph Roach, por exemplo, atribuem "um caráter político inerente à análise de performance que emergiu da teoria crítica; ela revisa, desafia, reescreve, interroga, e às vezes condena significados recebidos" ${ }^{139}$. Esta sobrevalorização do papel político na teorização da performance cultural acaba por impor o que Mckenzie chama de um desafio da eficácia, isto é, se a performance cultural é predominantemente tratada como um catalisador de transformação social e pessoal, seu potencial transgressor ou de resistência só pode ser avaliado em termos de eficácia.

\footnotetext{
TAYLOR, Diana. "Performance Studies: a hemispheric focus" in SCHECHNER, op. cit., p. 12.

137 MCKENZIE, Jon. Performance or else - from discipline to performance. Nova York: Routledge, 2001, p. 18.

138 O recorte de objeto que Mckenzie faz para a performance cultural é bastante próximo do que Schechner elege como objeto para os estudos da performance.

139 REINELT, Janelle e ROACH, Joseph (eds.). Critical Theory and Performance. Ann Arbor: University of Michigan Press, 1992, p. 2 apud MCKENZIE, op. cit., p. 32.
} 
Apesar de formulados a partir da virada dos anos 70 para os 80 , os estudos da performance reivindicam a protoformação de um paradigma desde meados da década de 50. Nos vinte primeiros anos, os modelos dominantes que guiavam este paradigma eram o teatro e o ritual. No limiar entre eles, na teatralização do ritual e na ritualização do teatro, tomava corpo uma forma particular - a presença física de um ator/performer e da audiência - e uma função particular - a transgressão de normas sociais e/ou estruturas simbólicas. Nos anos 80, a eficácia da transgressão deu lugar a uma nova eficácia, a da resistência. Enquanto no primeiro modelo, baseado na presença, o desafio político é transgredir um poder totalitário e "externo", não identificável com a performance; no segundo, o desafio político é oferecer resistência "a partir de dentro", subvertendo a hegemonia de um arranjo de poder no qual se está infiltrado ${ }^{140}$. Este segundo modelo de eficácia reconfigurou a importância do ritual, que passou a ser um material bruto para outro processo de modelização, centrado na performance art. $\mathrm{O}$ novo modelo é apoiado por uma aproximação da teoria da arte com a filosofia, em especial com o pós-estruturalismo. Esta valorização teórica é tal que o ápice do modelo de eficácia da resistência é um processo híbrido que pode ser descrito como teoria da prática ou prática da teoria. A presença deixa de ser valor preponderante aos estudos da performance, dando espaço para a mediação, tanto em seu caráter tecnológico (a partir da década de 80 passou a ser frequente o uso de tecnologias de transmissão de dados, de vídeo, de telefonia, etc, como recurso na proposição de uma performance) quanto na construção discursiva dos corpos.

Ao repensar poeticamente a discussão dos estudos da performance para propor um conceito que possa operar sobre a produção teatral contemporânea, Josette Féral pareceu percorrer o caminho inverso de Schechner (ou seja, em vez de formar um campo para-artístico para abordar o performático, ela preocupou-se em mapear as características do fenômeno teatral na contemporaneidade para fazer dele emergir as categorias de estudo).

\footnotetext{
140 Não por acaso, é neste momento histórico que a academia "institucionaliza" os estudos de performance, criando departamentos em prestigiosas universidades.
} 
Se o fenômeno teatral no século XX passou por mudanças paradigmáticas, como a perda da supremacia do texto dramatúrgico, a demanda por novos espaços teatrais afastados da convenção, a valorização do acontecimento e da experiência, dentre outros, o contrato que tinha se estabelecido ao longo da história do teatro entre artista e audiência também sofreu as consequências desta mudança de paradigma. Se o espetáculo teatral passou a ser uma polifonia significante, a conhecida fórmula de Peter Brook para descrever o teatro, "um espaço vazio onde passa um ator", carece de precisão. Ao mesmo tempo que buscar um "específico teatral" parece um projeto idealista e irrealista, a tarefa de compreender caracteres que constituem o fenômeno teatral contemporâneo é bastante urgente. Féral aceita este desafio ao detectar duas qualidades que aqui serão úteis para a análise dos pranks: a teatralidade e a performatividade $^{141}$.

Féral se questiona se a teatralidade é uma propriedade que é encontrada exclusivamente no teatro ou também no cotidiano. Para isso, propõe três situações de investigação. A primeira delas é a entrada de um espectador em um espaço teatral. Não há cortina (ou ela está aberta) e, enquanto acomoda-se em sua poltrona, o espectador observa o cenário já visível. Neste caso, algumas regras e signos teatrais são revelados, mesmo antes do início do espetáculo. Já há uma impressão do espetáculo, dada pela expectativa gerada pelo cenário. O palco já porta em alguma medida a teatralidade, e podemos concluir que a presença do ator não é pré-requisito para que esta teatralidade exista. Neste exemplo, o veículo de teatralidade é o espaço cênico.

A segunda situação é a do testemunho de uma discussão calorosa no metrô. Duas pessoas que discutem deixam o vagão em determinada estação e os passageiros que descem com elas na mesma estação acabam por saber que tinham testemunhado uma encenação, eram apenas atores simulando um desentendimento. Para os passageiros que permaneceram no metrô, o evento teatral permaneceu ignorado. Este exemplo sugere que a teatralidade depende da consciência do espectador de uma

141 Algumas citações de Féral não aparecem com referências bibliográficas porque são fruto de anotações minhas durante a disciplina que ela ministrou na ECA / USP em agosto de 2009, intitulada Teoria e prática do teatro: além dos limites. 
intenção teatral dirigida a ele, para que ele possa transformar em ficção o que ele considerava um evento da esfera do cotidiano.

O terceiro exemplo é a de um espectador sentado em um café. Ele olha os transeuntes como se eles fizessem parte de uma grande encenação organizada para entretê-lo. No entanto, os transeuntes ignoram a "leitura estética" do espectador e continuam em suas ações comuns, despreocupados. Quem inscreve a teatralidade neste exemplo é o olhar do espectador no café, sua tarefa de olhar é que a instaura. A conclusão é a de que

a teatralidade tem pouco a ver com a natureza do objeto investido - ator, espaço, ou evento - nem é necessariamente o resultado de uma ilusão, de um fazer-de-conta, de uma ilusão. (...) Mais do que uma propriedade com características analisáveis, a teatralidade parece ser um processo que tem a ver com um 'olhar' que postula e cria um espaço virtual e distinto pertencente ao outro, de onde a ficção pode emergir. ${ }^{142}$

A teatralidade, segundo Féral, depende então da criação de uma alteridade, de uma clivagem da vida cotidiana, do real. Esta clivagem pode partir do artista (como no exemplo do metrô), do espectador (como no exemplo do café), ou de ambos (como no exemplo da entrada no teatro). A teatralidade é uma espécie de "moldura" que destaca o evento da realidade através de um processo ativo de reconhecimento, de olhar e ser olhado. Então, pode-se dizer que a teatralidade é condição fundamental para a existência do teatro como espaço diverso do espaço cotidiano, mas não é verdade afirmar que toda relação de teatralidade conduz imediatamente ao teatro. É como se a teatralidade "contivesse" o teatro, mas o transbordasse, abarcando outros domínios.

É dentro desta perspectiva parateatral ou extrateatral da teatralidade que podemos examinar os pranks, em especial a modalidade de simulação. Quando eu tenho a intenção de me fazer passar por outra pessoa para iludir uma plateia, crio uma situação de teatralidade, seja no teatro ou fora dele. Quando esse recurso é usado na prática prank, o ativista tenta criar uma divisão na audiência: há uma audiência de primeiro nível, imediata, que assiste à ação e é enganada por ela, ou seja, é o alvo do

\footnotetext{
142 FÉRAL, Josette. "Theatricality: The specificity of theatrical languag e". Substance 98/99, vol. 31, n. 2 e 3, 2002, p. 97.
} 
prank; e há uma audiência de segundo nível, cúmplice dos pranksters para quem eles lançam uma piscadela. Isto ficará mais claro com a exposição de um exemplo.

Pensemos em Jude Finisterra, porta-voz da Dow Chemicals. A Dow é uma mega-corporação de produtos químicos, que atua em inúmeros setores industriais, como alimentação, construção civil, agricultura, farmácia, embalagens, automóveis, mobiliário, tecidos, etc. A Dow tem faturamento anual de 57,4 bilhões de dólares e emprega aproximadamente 46 mil pessoas em 35 diferentes países. Em 2001, adquiriu a Union Carbide, empresa que produz derivados do etileno, cuja aplicação vai desde brinquedos até elásticos, bactericidas, cosméticos e tintas. A Union Carbide é uma empresa de tradição no ramo químico, sua fundação data de 1898. Desde 1934 havia ampliado suas atividades para a Índia, sendo uma das primeiras empresas estadunidenses naquele país. Em dezembro de 1984, um vazamento no tanque de gás da usina da Union Carbide na cidade indiana de Bhopal causou a morte de aproximadamente 8 mil pessoas nas 72 primeiras horas. Mais 15 mil pessoas morreram em decorrência da exposição ao material tóxico e aproximadamente $120 \mathrm{mil}$ tiveram danos médicos crônicos irreparáveis, o que alçou Bhopal à marca de maior desastre industrial da história ${ }^{143}$. Em nenhum momento a Union Carbide assumiu total responsabilidade pelo ocorrido. A Dow Chemicals, no entanto, veio a público em 03 de dezembro de 2004 para aceitar totalmente o ônus que pesava sobre a subsidiária adquirida. Jude Finisterra foi ao vivo aos estúdios da BBC afirmar que "estava muito feliz em anunciar que a Dow estava aceitando plena responsabilidade sobre a catástrofe em Bhopal" ${ }^{144}$ e que a empresa tinha um plano de 12 bilhões de dólares para compensar as vítimas e despoluir a área que ainda apresentava resíduos tóxicos. A novidade se espalhou rapidamente através de agências de notícias. Durante horas foi a notícia mais acessada do site news.google.com. A CNN divulgou que, naquele dia, a

\footnotetext{
143 O site bhopal.org faz uma comparação numérica para se ter uma dimensão da tragédia: no acidente nuclear em Chernobyl, na Ucrânia, em 1986, 57 pessoas morreram diretamente e mais 4000 pessoas morreram de câncer devido à exposição ao material radioativo.

144 Ver o filme BICHLBAUM, Andy e BONANNO, Mike. The Yes Men fix the world, 2009.
} 
Dow teve, em 23 minutos, uma queda de 4,2\% no valor de suas ações na bolsa de valores de Frankfurt, o que representou um prejuízo de 2 bilhões de dólares.

Acontece que Jude Finisterra é um impostor. Jude é o equivalente inglês de Judas, o São Judas, das causas impossíveis. E Finisterra é o "fim do mundo". O nome foi cuidadosamente escolhido pelos Yes Men para realizar mais um de seus pranks de “correção de identidade". O homem que se fez passar por porta-voz da Dow Chemical é Andy Bichlbaum, que junto com Mike Bonanno desenvolve uma divertida e arriscada estratégia de pranks de simulação. Eles criam sites falsos, que simulam sites reais de empresas ou instituições. As informações são as mesmas, mas o campo "contato" direciona os e-mails enviados para a caixa de mensagem dos Yes Men. No caso da Dow, a BBC enviou, no final de novembro de 2004, um pedido de entrevista com um representante da empresa para o endereço de contato que encontrou no siteisca dowethics.com. Os jornalistas já estavam acostumados com as recusas da Dow em falar sobre Bhopal ou com as respostas-padrão do tipo "o desastre com gás nas instalações da Union Carbide India Limited em Bhopal foi uma tragédia que não deve jamais ser esquecida. É uma lembrança constante da fragilidade da vida e que a segurança deve ser a prioridade na indústria. Este infortúnio estimulou na indústria química a iniciativa Responsible Care, dedicada ao contínuo melhoramento no ambiente, saúde e performance de segurança" ${ }^{145}$. Por isso comemoraram a prontidão e as declarações de Finisterra. "Não diria que é um trote", diz Bichlbaum em tom jocoso, "é uma representação honesta do que a Dow deveria estar fazendo" ${ }^{146}$. Depois do prank revelado, a $\mathrm{BBC}$ solicitou uma entrevista com Bichlbaum, na qual ele sustentou que o verdadeiro trote era da Dow, quando afirmam que não podem assumir a responsabilidade por Bhopal. Questionado sobre a crueldade do prank para as pessoas na Índia que alimentaram falsas esperanças, Bichlbaum respondeu que não era nada comparado aos vinte anos de sofrimento impostos pela Union Carbide / Dow Chemical.

\footnotetext{
145 Declaração oficial da Dow sobre o desastre, citado em "Dow Chemical Just Says 'Yes' to Bhopal", disponível em http://theyesmen.org/dowtext/. O texto citado, no entanto, não aparece mais no site da Dow.

146 BICHLBAUM e BONANNO, op. cit.
} 
Bichlbaum simulando ser Finisterra enganou a $\mathrm{BBC}$ e, por horas, os espectadores diretos e indiretos do noticiário. Eles se comportaram como os passageiros do metrô no exemplo de Féral. Não houve teatralidade enquanto eles não conseguiram destacar a falsa notícia da realidade. No entanto, as consequências objetivas do prank dos Yes Men (a queda no valor das ações da Dow, a negativa da empresa da existência de algum porta-voz chamado Finisterra), sua eficácia, para evocar o termo de Mckenzie, foi o que desvelou a teatralidade da falsa entrevista. A $\mathrm{BBC}$ e seus espectadores foram a audiência de primeiro nível, ludibriados pelo prank de simulação. Os espectadores do filme documental sobre os Yes Men, os leitores de seu site, os espectadores do programa de entrevistas em que Bichlbaum revelou o prank são a audiência de segundo nível, os cúmplices dos ativistas, que frequentemente se sentem engajados pela mesma finalidade política da ação (a denúncia da impunidade das grandes corporações em relação às grandes tragédias ambientais, sociais e econômicas por elas causadas), inspirados por ela ou, ao menos, entretidos pela audácia da empreitada. Sobre esta divisão da audiência, Audrey Watters afirma:

Assim como outras formas de performances políticas, os pranks são dirigidos para uma "vítima" ou um alvo específico, mas também para uma plateia mais ampla. De acordo com o folclorista Barre Toelken, pranks têm várias plateias: insiders que perforwmam o truque, desavisados que sabem pouco ou nada a respeito e espectadores que são iniciados, que se tornam insiders também. (...) A performance do prank solidifica a identidade dos insiders e a coesão do grupo. Para alguns outsiders o prank pode informar, educar ou convencer; para outros, o prank só pode envergonhar, gerar repulsa ou ridicularizar. ${ }^{147}$

Retomando o ataque satanista de Luther Blissett na cidade de Viterbo, ainda que ele seja um prank híbrido, pois também guarda caracteres da modalidade de armadilha, sua porção de simulação é, da mesma forma, debitária da teatralidade: enquanto apenas a primeira versão do vídeo tinha ido ao ar, as emissoras televisivas e os espectadores ainda estavam confrontados com a hipótese da existência de rituais satânicos. Foi a emissão do segundo vídeo, no qual a missa negra era desmascarada,

147 WATTERS, Audrey. "'We can lick the upper crust' - pies as political pranks". Disponível em http://www.audreywatters.com - Acesso em 12 de maio de 2009. 
que conferiu teatralidade a posteriori ao primeiro vídeo, compartilhou a fraude com os espectadores, e fez com que o prank cumprisse seu objetivo. Um prank de simulação, funâmbulo sobre a área imprecisa que divide o visível e o invisível, é eficaz quando sua teatralidade emerge, quando a intenção teatralizante do prankster é compartilhada com os espectadores.

A divisão da audiência em dois níveis, com pelo menos o segundo destes níveis necessariamente consciente da teatralidade, é o que difere os pranks de simulação do teatro invisível. Dentre as técnicas e formas desenvolvidas por Augusto Boal no Teatro do Oprimido, o teatro invisível é uma estratégia de contaminação (Boal diz que o teatro invisível deve "explodir" e envolver as pessoas próximas desta explosão ${ }^{148}$ ) por meio da total supressão dos papéis de espectador e atores. O método para isso é a diluição da representação no cotidiano, sem que aqueles que a testemunham identifiquem que se trata de um "espetáculo". Nisto é rigorosamente igual ao segundo exemplo de Féral, aquele do metrô. A diferença está na emergência da teatralidade. Só através do reconhecimento, mesmo a posteriori, da intenção teatralizante do proponente $^{149}$ da ação é que Féral admite a presença da teatralidade, retroativamente. Em outros termos, não há teatralidade sem a consciência, mesmo tardia, da cisão entre realidade e não-realidade. Na proposta de Boal, no entanto, a recomendação é de que a intenção nunca seja revelada. Ele pretende que os acontecimentos cotidianos demandem uma tomada de posição dos cidadãos, ainda que isto custe a teatralidade. Por este motivo, no teatro invisível já que as testemunhas ignoram os "rituais teatrais", a audiência não se divide, toda ela é ludibriada pela simulação. Já o prank efetivo precisa de alguém que presencie um outro alguém ser ludibriado, e pode acontecer que ambos sejam a mesma pessoa.

Para além do fenômeno teatral convencionalmente instituído, a teatralidade aparece como categoria relevante para o sucesso dos pranks de simulação. A clivagem do real que inaugura uma alteridade, condição de existência da teatralidade, é

\footnotetext{
148 BOAL, Augusto. Teatro do oprimido e outras poéticas políticas. 5a. edição. Rio de Janeiro: Civilização Brasileira, 1988, p. 167.

149 Uso aqui o termo proponente para evitar a dicotomia ator-espectador da qual Boal discorda.
} 
apropriada pelos pranksters. Os objetos e eventos extraídos do cotidiano são encerrados em outra esfera significante. A teatralidade proposta por Féral não é um atributo material que pode ser verificado positiva ou negativamente, não tem existência autônoma, mas, antes, é um processo atualizado no sujeito por meio da consciência desta clivagem, de uma junção ou disjunção frente ao mundo. Este espaço potencial, que atrai a atenção do espectador e onde ele realiza a fissão do que é cotidiano e do que é construção simbólica, é incorporado através dos pranks como espaço de atuação política.

O outro conceito contemplado por Josette Féral, o de performatividade, é proposto para pensar o elemento que, segundo ela, está no centro do teatro contemporâneo. Como alternativa à delimitação conceitual de teatro pós-dramático feita por Hans Thies Lehmann, Féral sugere a ideia de um teatro performativo ${ }^{150}$. Para fazer isso, ela demarca uma compreensão de performance que está destacada, por um lado, de uma abordagem excessivamente "antropologizante" (leia-se os estudos da performance, de Schechner, que, na opinião dela, por muito quererem abarcar, acabam diluindo sua noção e eficácia teórica), e, por outro, de uma visão estetizante e restritiva herdada das vanguardas artísticas de associação exclusiva com a performance art. No cruzamento destes dois eixos uma grande parte das características do teatro atual pode ser encontrada.

Féral aproveita a ampliação da compreensão que Schechner oferece do ato de "performar". Para ele, performar evoca quatro processos. O primeiro é ser, isto é, a existência em si ou o comportamento; o segundo é fazer, estar em ação; o terceiro é mostrar o fazer, o que equivale a se dar a público, ter consciência de estar sendo visto; e o último é explicar a exposição do fazer (em inglês explain showing doing), ou seja, fundar a crítica e a reflexão teórica sobre o mundo da performance e o mundo como performance.

150 Esta justaposição teatro - performance não é nova, já Timothy Wiles lançava o termo teatro performance em 1980, no seu livro The Theatre Event. cf VILLAR, Fernando Pinheiro. "Interdisciplinaridade artística e La Fura dels Baus: outras dimensões em performance”, O Teatro Transcende, v. 11, Blumenau, 2002, p. 48. 
Ao lado dos quatro processos evocados pelo verbo performar, a performatividade deve à noção de comportamento recuperado ${ }^{151}$, uma (re)atualização viva de sistemas simbólicos sociais:

Os hábitos, rituais e rotinas da vida são comportamentos recuperados. O comportamento recuperado é um processo fundamental em qualquer tipo de performance. (...) Comportamento recuperado sou "eu me comportando como se fosse outro", ou "como me disseram", ou "conforme eu aprendi". (...) Sou "eu" em outro tempo ou estado psicológico. (...) Como são marcados, enquadrados e separados, o comportamento recuperado pode ser trabalhado, arquivado, brincado, manipulado, transmitido e transformado ${ }^{152}$.

Schechner sustenta que mesmo nas esferas para-artísticas ou extra-artísticas, quando estamos em performance apresentamos um comportamento já experimentado, já ensaiado, já treinado ${ }^{153}$. Mesmo ações que parecem absolutamente inaugurais são compostas por fragmentos de comportamentos aprendidos e treinados, moldados para a execução daquela ação.

Aí temos um paradoxo: se fazer e mostrar o fazer são atividades de fluxo contínuo, em constante mutação, como podem ser comportamentos recuperados? Em resumo, como pode uma performance ser sempre única e sempre repetida? Bem, em primeiro lugar, a recombinação dos fragmentos de comportamentos é infinita. Assim a variedade de associações possíveis entre estes fragmentos garante parcialmente a irrepetibilidade da performance. Em segundo lugar, mesmo que a característica material da performance seja repetida, as circunstâncias em que ela é atualizada estão em fluxo. A performance acontece na ação, interação e relação. Mesmo se a ação for sublinhada, treinada e separada da vida real, recuperada, as instâncias de interatividade e de relação são sempre e forçosamente diferentes.

“Quando Schechner menciona a importância da 'execução de uma ação' na noção de 'performer' ele, na realidade, não faz senão insistir neste ponto nevrálgico de

\footnotetext{
151 Tradução proposta por Regina Polo Müller para “Restored Behavior” em MÜLLER, Regina P. “Corpo em movimento e sujeito-personagem: discussão teórico-metodológica sobre uma pesquisa em dança indígena" in Anais do V Congresso Brasileiro de Pesquisa e Pós-Graduação em Artes Cênicas. Belo Horizonte, 2008, disponível em http:/www.portalabrace.org/vcongresso/resumospesquisadanca.html - Acesso 30 de novembro de 2009.

152 SCHECHNER, op. cit., p. 34-35

153 Ou seja, já “comportado". O jogo de palavras funciona melhor na língua inglesa: twice-behaved behavior.
} 
toda a performance cênica, do 'fazer"' ${ }^{154}$. A adesão das formas teatrais ao "fazer", ao "agir", é presente nas reflexões sobre o teatro desde a Poética de Aristóteles. A diferença, para Féral, está na primordialidade, na parcela do teatro contemporâneo que ela busca categorizar como performativo, do "fazer" em detrimento do "representar".

Em primeiro plano, no teatro performativo, aparece a execução das ações por parte dos performers. São expostos seus corpos, seu jogo, suas competências técnicas. Mais do que no domínio do representativo ou, se quisermos, da ilusão, o registro que se busca é o do desempenho. Assim, para a performatividade interessa menos a fratura entre o real e o ficcional, que era elemento substancial para a teatralidade. "As obras performativas não são verdadeiras, nem falsas. Elas sobrevêm" ${ }^{155}$, afirma Féral, ecoando Schechner. A performatividade está, por conclusão, associada ao desempenho da ação submetida a uma determinada rede de relações e interações, que, em vez de instaurar uma alteridade ficcional, um "como se", valoriza o acontecimento em si. Esta qualidade confere ao processo performativo um risco real para o performer, já que ele está pondo à prova o seu desempenho. Através deste risco real o teatro performativo coloca em cena a materialidade de seu processo, amplifica o aspecto lúdico e modifica a atividade dos participantes (como nos happenings ou na performance art a fronteira artista-espectador tende a ficar tênue ou desaparecer).

O esforço de Féral em detectar contribuições da performance (em suas acepções antropológica e estética, não se restringindo a nenhuma das duas) para a compreensão do teatro contemporâneo, e em buscar um conceito operativo, a performatividade, que reconhece estas contribuições, pode ser aproveitado para além da análise do fenômeno teatral propriamente dito. Quando pensada no âmbito da atuação política dos pranks, a performatividade poderia sugerir uma contradição com a representação direta definida por Brian Holmes, uma vez que a performatividade se afasta da representação e valoriza a ação. No entanto, uma reflexão sobre o significado de representação desfaz esta aparente contradição. Holmes propõe que se deve tomar a expressividade estética

\footnotetext{
154 FÉRAL, Josette. "Por uma poética da performatividade: o teatro performativo" in Sala Preta No. 8 Revista do Departamento de Artes Cênicas da USP. São Paulo, 2008, p. 201.

155 Ibid. p. 203.
} 
e política nas mãos e não delegá-las, mas exercê-las sem mediadores. É portanto uma autorepresentação, um chamado para o exercício político-estético do faça você mesmo. Assim, a acepção de representação em Holmes não conduz à esfera da ilusão que a performatividade rejeita. Não se representa um outro, mas, pelo contrário, coloca-se em primeiro plano a ação do ativista e seu desempenho. A performatividade, ao contrário de confrontar a representação direta, afirma sua expressividade autônoma.

Assim como no teatro performativo, a performatividade instaura nos pranks uma ontologia do acontecimento, da vivência em tempo real, derivada da emergência da ação e da ruptura da fronteira entre os papéis de ator e espectador. Cada indivíduo dançando em uma festa-evento do Reclaim the Streets, por exemplo, colabora de maneira performativa para a criação de um prank de situação. A sua adesão ao acontecimento, a sua presença no evento, retira-o de sua condição de espectador - ele vivencia a ação e suas consequências. Um indivíduo inserido em um prank de situação acaba se tornando um duplo, observador e agente, arrastado pela performatividade para uma esfera de participação que o coloca em risco e exige dele uma tomada de posição imediata e autoexpressiva.

Por fim, cabe afirmar que os paradigmas da teatralidade e da performatividade não são excludentes, mas complementares e interpenetrantes. Isto permanece verdadeiro tanto para o projeto de Féral, de análise do fenômeno teatral contemporâneo quanto para o deste trabalho, o de análise dos pranks como opção performativa para a rede de ativismo político contemporâneo. Do ponto de vista da teatralidade, é a relação do agente com o espectador que é colocada à prova. Pode-se dizer, por isso, que o olhar externo, aquele da recepção, é o mobilizado pela teatralidade. Seu processo depende do sucesso da criação de uma região de alteridade, em que cada um dos participantes é capaz de identificar-se a si e ao outro. Diferentemente, na perspectiva da performatividade, a ação do performer é o elemento disparador. Desta maneira, trata-se de uma mobilização de um olhar interno, participativo. Envolvidos pelo acontecimento, os participantes têm seus papéis diluídos e compartilhados. 


\section{CARTOGRAFIAS DA AUTONOMIA}

O jogo é uma maneira alada de ver a vida.

Eugen Fink

Se é possível identificar o aspecto performativo da prática do prank na atividade de grupos e indivíduos cuja militância redunda em eventos concentrados (como os Dias de Ação Global, por exemplo), conforme vimos no primeiro capítulo, também é possível fazê-lo na malha difusa das pequenas ações insurgentes, rebeldes e espontâneas que pululam o espaço urbano. Motivados ou não pelas macroações de protestos, frequentes entre 1994 e 2003, os participantes da rede de ativismo político contemporâneo que investem seus esforços na manutenção desta malha difusa não devem de maneira alguma ser subvalorizados. Ao centrar suas ações no cotidiano ordinário, formam um ecossistema favorável para o surgimento e proliferação da prática do prank, dada a relativa segurança que o anonimato garante aos ativistas.

Por meio de uma observação participativa, pude pessoalmente acompanhar, ao longo desta pesquisa, ações de grupos e indivíduos ativistas no Brasil e na Europa, nas mais variadas frentes políticas e com as mais variadas metodologias. Percebi um fator bastante recorrente em diversas destas manifestações: a reivindicação pelo espaço. Se pensarmos em dois dos exemplos até aqui mencionados, tanto uma festa rave que brota não-autorizada no centro financeiro de Londres quanto declarações falsas de um porta-voz impostor de uma grande corporação em um telejornal são reivindicações por espaço. No primeiro caso, trata-se do espaço físico, invadido pela cultura do automóvel, pela especulação imobiliária, pelos outdoors publicitários, pela privatização do espaço público. No segundo caso, trata-se do espaço das ideias, o espaço intangível da comunicação, da informação e da ideologia do consumo. O papel dos pranks como elemento performativo desta disputa por estes dois tipos de espaço é o tema deste capítulo. 


\subsection{A CIDADE RETOMADA}

Sob o pavimento, a praia,

Slogan do maio de 68 francês

O verbo inglês to reclaim pode ser traduzido como reclamar, recuperar, reivindicar, retomar. Quando o Reclaim the streets começou a promover suas ações em meados da década de 90, o nome do grupo sugeria que algo nas ruas precisava ser recuperado. A ideia era simples: as ruas são o local público por excelência, nas ruas a urbe se funda e interage. As ruas pertencem às pessoas. Precisam, portanto, ser retomadas por elas.

Apesar da premissa antiautoritária e abertamente democrática das ruas, boa parte dos deslocamentos urbanos estão restritos a atividades diretamente ligadas à reprodução do modo de produção capitalista: deslocamento para o trabalho e deslocamento para o consumo. O movimento pelas ruas da cidade é avaliado em termos de eficiência, funcionalidade e velocidade. O "outro" sempre representa uma ameaça: um acidente de trânsito, um assalto, um atraso no trajeto. A sensação de risco, o esmagador individualismo e a alienante objetividade moldam a experiência e a expectativa de deslocamento pelas ruas da cidade ${ }^{156}$.

Mas a relação com o entorno pode ser pautada por valores lúdicos, críticos, criativos e insurgentes. É esta a ideia que move o Street Training, uma maneira nãousual de acessar o ambiente urbano, mesclando psicogeografia ${ }^{157}$, parkour ${ }^{158}$, brincadeiras e protesto. Idealizado pela performer inglesa Lottie Child, o Street Training adota exercícios poéticos, divertidos, desafiadores, considerados por ela

156 Friedrich Engels escreveu "Essa indiferença brutal, esse isolamento insensível de cada indivíduo em seus interesses privados, avultam tanto mais repugnantes e ofensivos quanto mais esses indivíduos se comprimem num espaço reduzido; e mesmo que saibamos que esse isolamento do indivíduo, esse egoísmo tacanho é em toda parte o princípio básico de nossa sociedade hodierna, ele não se revela nenhures tão desavergonhadamente, tão autoconsciente como justamente no tumulto da cidade grande" ( apud BENJAMIN, Walter. "O flâneur" in Obras escolhidas III: Charles Baudelaire, um lírico no auge do capitalismo. São Paulo? Brasiliense, 1989, p. 200.

157 O conceito de psicogeografia relaciona o espaço e o deslocamento com os efeitos emocionais e afetivos. Detalho o assunto mais abaixo.

158 O parkour é uma prática atlética que envolve a superação de obstáculos arquitetônicos ou naturais ao longo de um determinado caminho. Saltos, escaladas, aterrissagens, equilíbrios, rolamentos, fazem parte do vocabulário corporal exigido pelo parkour. 
como as habilidades de sobrevivência urbana contemporânea, uma espécie de arte marcial para o século XXI. "Street Training é a arte de treinar constantemente nossos corpos e mentes para ocupar criativamente as ruas da cidade. É consenso que o entorno nos afeta poderosamente. Street Training nos ensina que podemos afetar de maneira igualmente poderosa o entorno tanto com nossos pensamentos quanto com nossas ações" ${ }^{159}$.

Para praticar o Street Training, nenhuma experiência prévia e nenhum "ensaio" é requerido. Uma sessão começa com o encontro dos participantes em algum local prédeterminado. Minha primeira experiência foi marcada para a estação de metrô de Liverpool Street, no centro de Londres, em 20 de julho de 2008. Após breves apresentações dos aproximadamente dez membros do grupo, Lottie deu as boas-vindas e introduziu a prática para os novatos, ressaltando a autonomia e a responsabilidade que os participantes deveriam adotar sobre suas ações. Como aquecimento, fizemos uma caminhada em duplas pelo bastante movimentado saguão da estação, sendo que um dos membros da dupla permanecia de olhos fechados durante o trajeto e era guiado pelo companheiro. Em seguida, um exercício foi proposto: aproveitando o chão liso da estação, os street trainers tomavam impulso e se atiravam no chão, buscando escorregar o máximo possível. Saímos para a rua, e procuramos identificar lugares de esconderijo, tanto para pessoas quanto para objetos: buracos, fendas, espaços atrás de arbustos ou de cercas, sob tampas de bueiros, lugares improváveis que o mapa não cobre. Neles deixamos "presentes" para a posteridade: frutas, poemas, sementes de flores. Pudemos compartilhar nossas próprias experiências e opiniões sobre esconderse e mostrar-se. Contamos uns aos outros quais eram os elementos que mais nos chamavam a atenção quando estávamos andando pelas ruas. Cada um expôs uma diferente técnica de realizar algo que gosta de fazer ao longo do trajeto, desde cheirar flores até furtar conversas alheias. Continuamos nossa sessão com um exercício físico. Uma passarela se elevava junto a um prédio comercial, criando um conjunto favorável para uma escalada de aproximadamente cinco metros de altura. Cada um experimentou 
seu limite até onde julgava adequado, não havia prêmios ou pontos a serem conquistados. Nos poucos pedaços de terra cercados pelo concreto que encontramos pelo caminho, plantamos sementes de plantas nativas da região, na esperança de que encontrassem recursos para brotarem. Com giz, escrevemos frases nas calçadas, demos nossas colaborações às placas de publicidade. Fizemos arriscados "furtos reversos", nos quais deixamos poemas nos bolsos dos transeuntes. Cada um de nós escreveu três desejos e os penduramos com fitas nos galhos do que escolhemos ser a "árvore dos desejos", deixando canetas e papel para futuros passantes desejosos. Ao fim do percurso, tomamos um tradicional chá na Spitafields City Farm, uma fazendinha modelo simpática bem no centro da cidade. Ali discutimos nossa sessão, quais tinham sido os limites enfrentados, como interagimos em grupo, que lições aprendemos.

São as habilidades, capacidades e propostas dos participantes que são exercitadas no Street Training. "É a arte de fazer o que nós faríamos de qualquer forma, aplicando nossas maneiras de fazer sentido no mundo, realizando nossos próprios rituais e jogando nossos próprios jogos" ${ }^{160}$. Se eu tenho uma boa ideia para um jogo ou uma brincadeira, ou mesmo se meu olhar, minha escuta ou meu tato são atraídos para algum elemento do caminho, eu trato de compartilhar com os participantes do grupo, para formar um repertório comum de diversão e de expressão nas ruas.

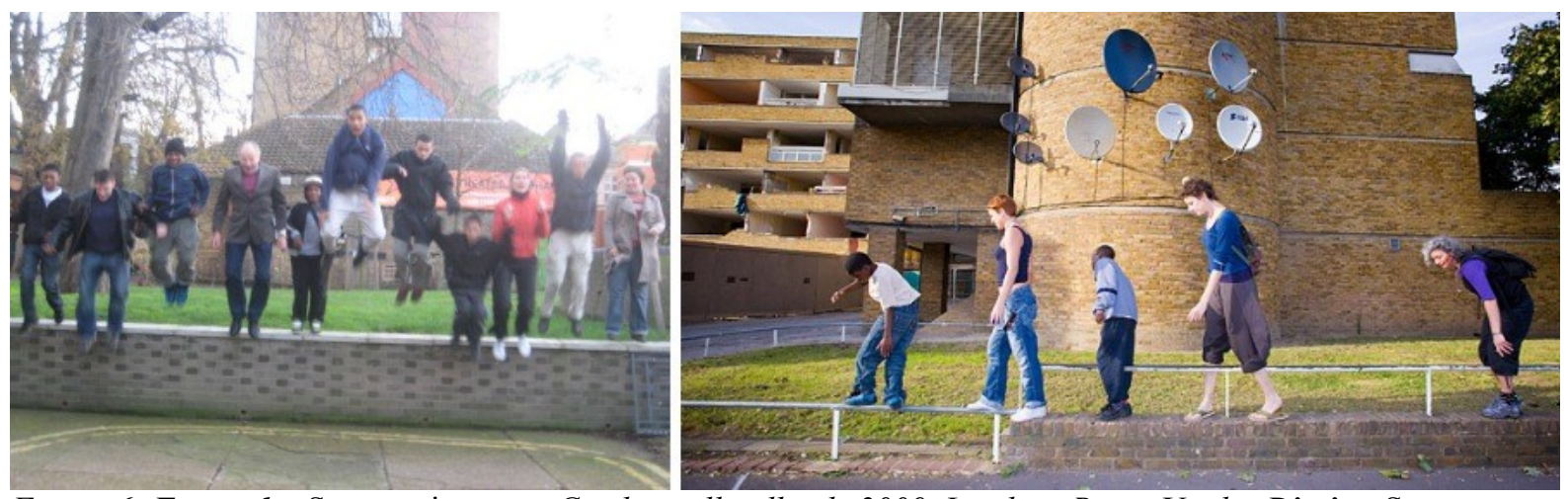

Figura 6: Esquerda: Street trainers em Camberwell, julho de 2009, Londres, Reino Unido. Direita: Street trainers em Peckham, setembro de 2008, Londres, Reino Unido.

O Street Training combina três componentes: o caminho da segurança, o caminho da alegria e o caminho da serenidade. A experiência com o espaço urbano $160 \quad$ Ibid. p. 1. 
privilegia, normalmente, a segurança em detrimento dos outros dois. Quando Lottie preocupou-se em elaborar um manual prático de Street Training, quis recolher depoimentos de transeuntes sobre como ser seguro, alegre e sereno em uma grande cidade. De fato, as pessoas tinham muito a dizer sobre segurança, mas não tinham muitas sugestões sobre serenidade ou alegria, já que estes caminhos estavam, para elas, alienados da relação com o espaço urbano.

É interessante perceber a recepção do Street Training em uma cidade que ainda sente os reflexos dos ataques de 07 de julho de 2005, quando quatro homens-bomba explodiram (três no metrô, um em um ônibus), causando a morte de 56 pessoas e ferindo 700, em retaliação à participação do Reino Unido na invasão do Iraque. Somese a isso o assassinato, também no metrô, do brasileiro Jean Charles de Menezes no dia 22 de julho de 2005, confundido com um suposto terrorista suicida pela polícia metropolitana. Estabeleceu-se desde então uma forte tensão na multiétnica Londres, com vigilância ostensiva e campanhas de delação ${ }^{161}$.

Um grupo de pessoas heterogêneo em faixas etárias e etnias cheirando flores, escalando prédios, checando a acústica de túneis, aparece como uma subversão da ordem rígida das coisas neste ambiente tenso. A ausência de linha divisória entre o que pode ser considerado "comportamento suspeito" e o "comportamento criativo" faz com que o Street Training gere um prank de situação, um campo performativo desviado da realidade cotidiana, mas que mantém com ela uma relação lúdica e irônica. A performatividade pulsante do Street Training está na retomada do espaço urbano como espaço comum, de festa, de jogo.

As reações dos transeuntes são variadas. Estranheza e curiosidade são as mais frequentes, embora eu também tenha presenciado simpatia, aversão e até engajamento - pedestres interrompendo seu trajeto para fazer parte do grupo.

161 Em março de 2009, por exemplo, a polícia metropolitana de Londres lançou uma campanha publicitária com imagem de uma praça repleta de crianças, mães e senhores (sintomaticamente todos brancos, com exceção de uma moça negra, coadjuvante, ao fundo) ladeada com o texto "Uma bomba não explodirá aqui porque um vendedor denunciou que alguém prestava atenção às câmeras de vigilância. Não confie nos outros. Se você suspeita, denuncie." http://www.publicadcampaign.com/uploaded images/ street chemicals_cctv-784215.jpg 
Nas sessões em que estive presente, duas vezes fomos confrontados com a vigilância. Na primeira delas, um segurança barrou nossa passagem pelo pátio de uma empresa. O grupo rapidamente se dividiu em dois, impossibilitando a ação do vigilante solitário. Na segunda vez, eu estava realizando uma ação a respeito da imensa quantidade de câmeras de circuito fechado de tv distribuídas pelo Reino Unido ${ }^{162}$. Escrevi frases engraçadas e motivadoras em cartazes, e minha tarefa era mostrá-los ao longo do caminho para todas as câmeras que eu encontrasse: "Eu (coração) CCTV", “1984”, “Quer casar comigo?”, etc. Depois de alguns minutos, um policial me abordou para checar o que eu estava fazendo. Eu expliquei que julgava ser profundamente solitário e tedioso o trabalho de observação daqueles monitores orwellianos, e que só tinha proposto um modo de animar os vigilantes do panóptico, interagindo com eles. Após ler cuidadosamente cada um dos cartazes, o policial os devolveu. Perguntei-lhe se poderia continuar fazendo aquilo. Ele respondeu, com algum menosprezo: "Whatever floats your boat" $" 163$.

O contato com Lottie Child rendeu uma colaboração profícua. No início de 2009, ela recebeu uma bolsa do British Council para fazer uma residência artística no Brasil. Desenvolveu sua pesquisa no Rio do Janeiro, na comunidade do Morro dos Prazeres. Aproveitando a presença de Lottie no país, propus para a Unicentro (Universidade Estadual do Centro-Oeste do Paraná) a realização de um evento envolvendo a prática do Street Training. A professora Margie Rauen abraçou a ideia e no final de março realizamos, em Guarapuava, uma oficina que contou com uma palestra de abertura minha, intitulada "Políticas do Espaço Urbano e Poéticas da Multidão", seguida de uma exposição de Lottie sobre a origem e desenvolvimento de seu trabalho. No dia seguinte, os alunos do curso de Arte-Educação participaram de duas sessões de Street Training pelas ruas da cidade e se comprometeram em promover encontros regulares do grupo formado.

\footnotetext{
162 O Reino Unido é o país com maior número de câmeras de vigilância per capita. Estima-se 4,8 milhões de câmeras, uma para cada doze pessoas. GOLDFARB, Michael. "Living under the CCTV gaze" Disponível em http://www.globalpost.com/dispatch/united-kingdom/090328/living-under-the-cctv-gaze Acesso em 15 de janeiro de 2010.

163 Literalmente, "O que quer que faça seu barco flutuar".
} 
Mesmo após o retorno de Lottie para a Inglaterra, mantive o contato com ela e ministrei, em novembro de 2009, uma oficina de Street Training no Festival de Cultura do Paraná, ocorrido em Curitiba. Dentre os exercícios executados, destaco a formação de uma torcida organizada para jogadores de dominó e a escalada de árvores de praças centrais da cidade. A adesão e entusiasmo dos participantes me motivam a pensar na manutenção futura de um grupo regular de street trainers.

Além das experiências em várias cidades do Reino Unido e no Brasil, Lottie tem sido convidada para ministrar sessões na Áustria, na Dinamarca, na Alemanha e na Finlândia ${ }^{164}$, sempre com especial atenção para as tensões sociais latentes no espaço urbano. Em setembro de 2008, por exemplo, Lottie realizou sessões em Peckham, um bairro londrino com forte presença de imigrantes e com recorrente violência de gangues. As crianças da região, algumas delas em situação de risco social, reapresentaram para os adultos de sua própria vizinhança, mostraram como elas se divertem em um espaço economicamente marginalizado ${ }^{165}$.

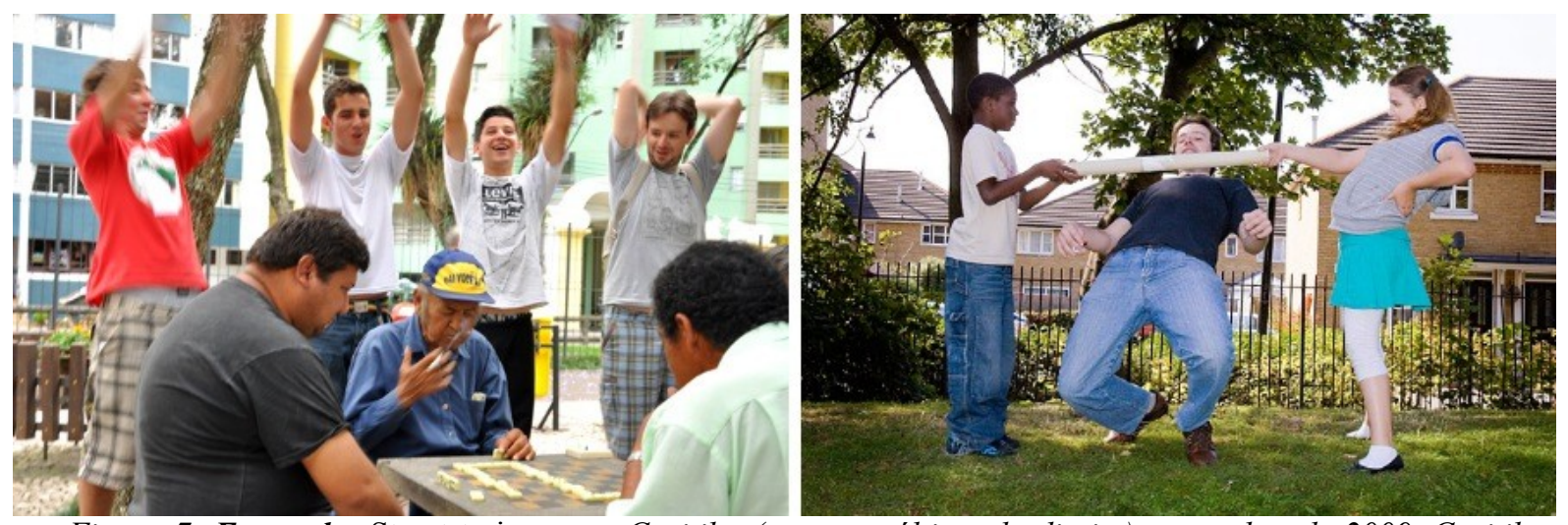

Figura 7: Esquerda: Street trainers em Curitiba (eu sou o último da direita), novembro de 2009, Curitiba. Direita: Eu me esforçando no limbo dancing do street training de Peckham, setembro de 2008, Londres, Reino Unido.

A representação direta de Holmes tem no Street Training um excelente exemplo. Através de uma prática lúdica e crítica, os participantes exercem sua autoexpressividade estética e política, ao mesmo tempo em que o uso tido como "normal" do espaço é subvertido, as regras de funcionalidade, produtividade e velocidade impostas pelo modo de produção capitalista são suspensas em nome de um

\footnotetext{
164 Mais informações em http://www.streettraining.org/

165 Um breve videoclipe do evento, editado por Larissa Nowak, pode ser visto em http://www.youtube.com/ watch? $\mathrm{v}=41 \mathrm{mlwRaeybI}$
} 
prank de situação comunitário. O Street Training configura um prank em que há a resistência à domesticação dos deslocamentos urbanos, onde a cidade é retomada pelos seus cidadãos. Esta prática se insere em uma longa tradição de diálogo estético e político com a urbe.

$\mathrm{Na}$ análise de Baudelaire e das Passagens parisienses do século XIX, Walter Benjamin teoriza sobre a figura do flâneur, apresentada pelo poeta francês: o errante urbano que rebela-se contra a modernidade e gasta seu tempo deleitando-se com o insólito e o absurdo na concentração populacional das metrópoles pós-Revolução Industrial: "Uma embriaguez acomete aquele que longamente vagou sem rumo pelas ruas. A cada passo, o andar ganha uma potência crescente; sempre menor se torna a sedução das lojas, dos bistrôs, (...) e sempre mais irresistível o magnetismo da próxima esquina, de uma massa de folhas distantes, de um nome de rua" ${ }^{166}$. Como construtor simbólico do espaço urbano, o flâneur é ancestral dos street trainers.

Foi durante a Abertura da Grande Temporada Dadá, em 14 de abril de 1921, em Paris, que o flanar baudelaire-benjaminiano foi elevado à categoria estética. Convocados para um encontro em frente à igreja de Saint Julien-le-Pauvre, alguns dadaístas partiram em uma excursão aleatória, passando por lugares banais da cidade. Apesar de parcialmente frustrada por uma chuva torrencial, os participantes distribuíram presentes para os transeuntes, leram trechos retirados ao acaso do dicionário Larousse e tentaram fazer com que as pessoas deixassem suas casas para tomar as ruas. Aquela foi a primeira proposta estética de uma série de incursões, perambulações e derivas que marcaram não só o Dadá, mas vários momentos da arte e da antiarte do século XX (e, agora, também do XXI) ${ }^{167}$.

As deambulações surrealistas se inscreveram nesta tradição, pretendendo uma "escrita automática" do espaço real. Estes intermináveis passeios se converteram em uma das atividades mais praticadas pelos surrealistas. Neles, o encontro de objetos, os acontecimentos inesperados e os jogos coletivos compunham o ar da eventualidade e

\footnotetext{
166 BENJAMIN, op. cit., p. 186

167 Sobre arte e antiarte entre 1950 e 1985, ver HOME, Stewart. Assalto à cultura: utopia, subversão, guerrilha na (anti) arte do século XX. São Paulo: Conrad, 2004.
} 
do acaso que eram refletidos nas obras dos surrealistas. Eles desenvolveram o que chamavam de mapas influenciais, que buscavam reconhecer as pulsões que a cidade exercia sobre o afeto dos transeuntes.

Tanto a caminhada Dadá quanto a deambulação surrealista demonstraram a recusa da criação de um objeto de arte mediador e a proposição de uma ação estética não-representativa e com alto grau de performatividade, que se desenvolve no tempo e no espaço cotidianos, na interação com o ambiente urbano em fluxo. A moderação na radicalidade dos procedimentos, no entanto, foi criticada posteriormente pelos situacionistas. "O dadaísmo quis suprimir a arte sem realizá-la; e o surrealismo quis realizar a arte sem suprimi-la"168, escreveu Guy Debord, para quem a supressão e a realização da arte eram dois processos inseparáveis da superação da arte. $\mathrm{O}$ alcance dos projetos dos dadaístas e dos surrealistas e a crítica situacionista foram abordados por Francesco Careri:

O Dadá havia intuído que a cidade poderia constituir um espaço estético operado mediante ações cotidianas/simbólicas e havia convidado os artistas a abandonar as formas consagradas de representação, apontando em direção à intervenção direta no espaço público. $\mathrm{O}$ surrealismo, ainda que talvez não compreendesse sua importância enquanto forma estética, utilizou $\mathrm{o}$ andar - o ato mais natural e cotidiano da conduta humana - como modo através do qual investigar e descobrir as zonas inconscientes da cidade, aquelas partes que escapam do projeto e que constituem o inexprimível e o intraduzível em representações tradicionais. Os situacionistas acusaram os surrealistas de não haver levado às últimas consequências as potencialidades do projeto dadaísta. Situar-se "fora da arte", a arte sem obra ou artistas, a recusa da representação e do talento pessoal, a busca de uma arte anônima, coletiva e revolucionária, tudo isso seria combinado, junto com a prática do andar, pela deriva dos letristas/situacionistas. ${ }^{169}$

A Internacional Situacionista, formada em 1957 da junção da Internacional Letrista (grupo ao qual Debord pertencia), do Movimento Internacional por uma Bauhaus Imaginista e da Associação Psicogeográfica de Londres (que se resumia a um integrante), tinha uma forte preocupação sobre as conexões entre o planejamento urbano, a arquitetura e o modo de produção capitalista. Assumidamente marxista, a IS fazia da crítica ao surrealismo e ao dadá uma revisão da décima primeira tese de Karl

\footnotetext{
168 DEBORD, Guy. op. cit., parág. 191.

169 CARERI, Francesco. Walkscapes: el andar como práctica estética. Barcelona: Ed. Gustavo Gili, 2007. Land\&Scapes Series, p. 90.
} 
Marx sobre Feuerbach: "Os filósofos têm apenas interpretado o mundo de maneiras diferentes; a questão, porém, é transformá-1o" ${ }^{170}$. A paráfrase artística da ambição marxiana pretendia a conversão da vida em um jogo apaixonante, prazeroso, criativo, urgente e crítico, que recusasse a separação e a alienação imposta pelo capitalismo sobre a experiência com o tempo e o espaço. A crítica unitária da sociedade deveria contemplar também uma crítica da geografia humana, na qual os indivíduos se relacionassem historicamente com o espaço. Essa motivação já estava presente no pensamento do jovem Debord, quando ele ainda fazia parte da Internacional Letrista. Ele advogava um urbanismo unitário, uma apropriação afetiva e histórica do espaço urbano. Isso se daria através da deriva, uma técnica de percepção psicogeográfica das cidades, em que as ambiências urbanas interferem no estado de espírito dos indivíduos e geram o deslocamento. $\mathrm{Na}$ apresentação da coletânea de textos situacionistas Apologia da Deriva, a professora Paola Berenstein Jacques esclarece de que maneira isto acontece:

Para tentar chegar à construção total de um ambiente, os situacionistas criaram um procedimento ou método, a psicogeografia, e uma prática ou técnica, a deriva, que estavam diretamente relacionados. A psicogeografia foi definida como um "estudo dos efeitos exatos do meio geográfico, conscientemente planejado ou não, que age diretamente sobre $\mathrm{o}$ comportamento afetivo dos indivíduos". E a deriva era vista como um "modo de comportamento experimental ligado às condições da sociedade urbana: técnica da passagem rápida por ambiências variadas.(...)" Ficava claro que a deriva era o exercício prático da psicogeografia e, além de ser também uma nova forma de apreensão do espaço urbano, ela seguia uma tradição artística desse tipo de experiência. A deriva situacionista não pretendia ser vista como uma atividade propriamente artística, mas sim como uma técnica urbana situacionista para tentar desenvolver na prática a ideia de construção de situações através da psicogeografia. A deriva seria uma apropriação do espaço urbano pelo pedestre através do andar sem rumo. A psicogeografia estudava o ambiente urbano, sobretudo os espaços públicos, através das derivas e tentava mapear os diversos comportamentos afetivos diante desta ação básica do caminhar na cidade ${ }^{171}$.

De fato, o plano de superação da arte dos letristas e dos situacionistas estava necessariamente ligado à relação com a cidade. Na revista Potlach, eles enunciavam:

\footnotetext{
170 MARX, Karl. "Teses sobre Feuerbach”, disponível em http://www.marxists.org/portugues/marx/1845/ tesfeuer.htm - Acesso em 05 de janeiro de 2008.

171 INTERNACIONAL SITUACIONISTA. Apologia da deriva - escritos situacionistas sobre a cidade . Rio de Janeiro: Casa da Palavra, 2003, p. 22.
} 
"Se a poesia está extinta nos livros, agora existe na forma das cidades: a nova beleza será de SITUAÇÃO" ${ }^{172}$. A construção de situações era um novo urbanismo, onde não seria necessária a arte institucionalizada, legitimada pelo poder político ou econômico, e, portanto, separada. Era a intenção de elevar a vida à promessa contida na arte. A Internacional Letrista considerava-se uma vanguarda além da arte, de obras inexistentes. A construção de situações por eles proposta pretendia afetar esteticamente o conjunto das relações sociais.

O “passo além” dos letristas/situacionistas em relação às explorações do espaço dadaístas e surrealistas foi a crítica das forças envolvidas na construção urbanista, que atendiam às exigências do capital. Anselm Jappe afirma que a trajetória do pensamento de Debord "tem como programa a revolução da vida cotidiana, a realização dos desejos oprimidos, a recusa dos partidos, dos sindicatos e de todas as outras formas de luta alienadas e hierárquicas, a abolição do dinheiro, do Estado, do trabalho e da mercadoria". ${ }^{173}$ O projeto de superação da arte (que fica claro sobretudo na posição da Internacional Situacionista após 1962) não se encerra na discussão sobre estética, mas articula uma esfera híbrida em que arte, urbanismo, manifestação política e conduta social se fundem numa experiência complementar. Um exemplo disso foi a participação dos situacionistas e de suas ideias nos protestos de maio de 68, na França.

Ainda que seja exagerado estabelecer as ideias situacionistas como causadoras exclusivas dos protestos ${ }^{174}$, seus ecos são identificáveis na fraseologia radical e criativa impressa em panfletos ou pintadas nas paredes de Paris: "Seja realista, exija o impossível”, "É proibido proibir", “A imaginação no poder”, “O sonho é realidade”, "Sob a calçada, a praia”, "Eles compraram sua felicidade. Roube-a!", “O respeito foi perdido. Não vá procurá-lo!”, “A arte morreu. Não há nada que Godard possa fazer quanto a isso", "Como se pode pensar livremente à sombra de uma igreja?", "Numa sociedade que aboliu todas as aventuras, a única aventura que resta é abolir a

\footnotetext{
172 JAPPE, Anselm. Guy Debord. Petrópolis: Vozes, 1999, p. 82.

173 JAPPE, Anselm. “A arte de desmascarar”. Folha de São Paulo, caderno MAIS!, páginas 4-5, 17 de agosto de 1997.

174 A Sociedade do Espetáculo, principal obra de Guy Debord, foi publicada seis meses antes.
} 
sociedade", "A revolução é incrível porque é real", "Vamos banir o aplauso, o espetáculo está por toda parte", "Quanto mais eu faço revolução, mais quero fazer amor. Quanto mais faço amor, mais quero fazer revolução", “A beleza está nas ruas", "Mesmo se Deus existisse seria necessário aboli-lo", "Somos todos indesejáveis", "Trabalhadores de todo o mundo, divirtam-se" ${ }^{175}$. Mais do que reivindicações salariais ou reformas políticas, a contestação de 68 era fruto de uma crise de autoridade, identidade e representação na sociedade francesa. Queria mudar a vida, as relações que constituíam a família, os papéis sexuais, o estado, a igreja, a educação, as relações de produção - queria a demolição da sociedade como um todo, esta sociedade que era definida por Debord como "espetacular mercantil".

Uma interessante descrição do "espírito de época" da juventude de 68 foi dada pelo juiz incumbido do caso dos universitários de Estrasburgo que, dois anos antes, inspirados pelos situacionistas, ganharam a eleição do Diretório Acadêmico da Universidade defendendo a plataforma de acabar com o próprio Diretório. Escreveu, então, o juiz nos autos do processo:

Os estudantes, ainda há pouco adolescentes, desprovidos de qualquer experiência, com a cabeça repleta de mal digeridas teorias filosóficas, sociais, políticas e econômicas, e sem saberem como dissipar o seu melancólico aborrecimento do dia a dia, emitem a vã, orgulhosa e irrisória pretensão de produzir juízos definitivos e indignamente injuriosos sobre os seus condiscípulos e professores, sobre Deus, as religiões, o clero, os governos e os sistemas políticos e sociais do mundo inteiro, e, depois disto, rejeitando qualquer moral e quaisquer entraves legais, não hesitam sequer em louvar o roubo, a destruição dos estudos, a supressão do trabalho, a subversão total e a revolução mundial proletária ininterrupta a fim de se gozar sem impedimentos ${ }^{176}$.

Guardadas as devidas proporções da carga negativa da valoração do juiz, os estudantes de Estrasburgo e, depois, os jovens entrincheirados na Sorbonne em 1968, de fato pretendiam um "gozo sem impedimentos" enquanto inventavam um novo mundo: um espaço potencial de ruptura com hierarquias e com a sociedade do espetáculo.

\footnotetext{
175 Estas e outras fases dos protestos estão em BESANÇON, Julien (org). Les murs ont la parole - mai 68. Paris: Tchou, 2007.

176 INTERNACIONAL SITUACIONISTA. Situacionista - teoria e prática da revolução. São Paulo: Conrad, 2002. Col. Baderna, P. 13.
} 

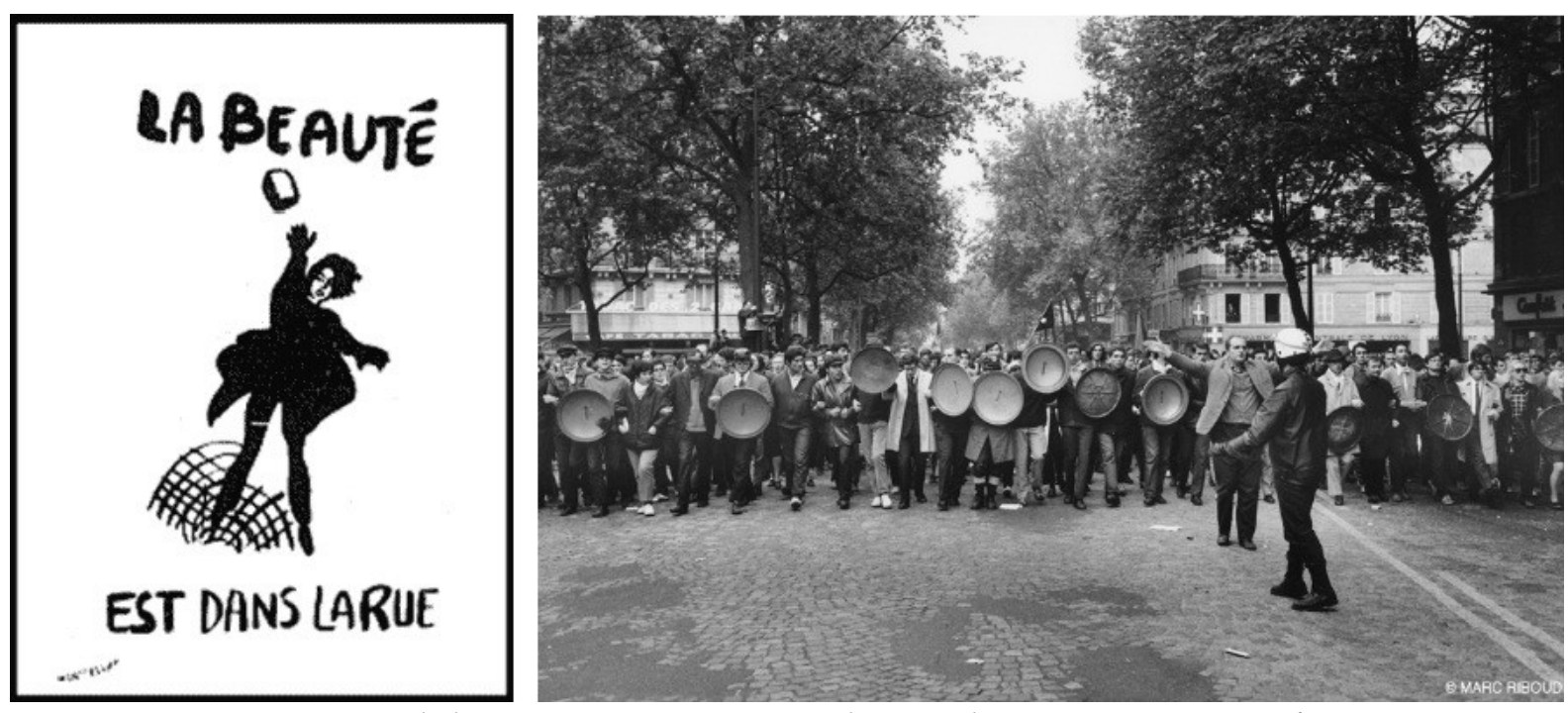

Figura 8: Esquerda: "A beleza está nas ruas", cartaz de maio de 1968. Direita: Manifestações em Paris, maio de 1968.

A motivação que está presente na linhagem flaneur-dadá-surreal-situacionista (e que, de alguma forma, redundou no maio de 68), também aparece, espontânea e empiricamente, por meio de outros métodos e práticas, no Street Training, sobretudo em um conjunto de performances que pretende o descondicionamento do espaço público. Se a arquitetura e o urbanismo regem a organização das cidades com uma orientação produtivista e individualista pouco disfarçada, esta tradição insurrecional da qual o Street Training faz parte se aproxima da reescrita performativa do espaço público que o coletivo Space Hijackers conceitua como anarquitetura ${ }^{177}$.

Os Space Hijackers existem desde 1999 e atuam especialmente em Londres. Dedicam-se a "lutar contra a constante invasão do espaço público por instituições, corporações e planejadores urbanos, [se opondo] à maneira com que o espaço público está sendo erodido e substituído por espaço de lucro corporativo, (...) e à maneira com que os usuários do espaço são postos sob crescente escrutínio e controle por aqueles que são proprietários ou administradores do espaço" ${ }^{178}$. As ações de anarquitetura que eles levam a cabo são tentativas irônicas, lúdicas e debochadas de, como a tradução do nome do grupo sugere, sequestrar o espaço tornado privado. Para isso os hijackers promovem performances e criam objetos que pretendem corromper a cultura da

\footnotetext{
177 A conexão do Street Training com os Space Hijackers não é fortuita. Lottie Child colaborou em diversas ações dos hijackers.

178 Disponível em http://www.spacehijackers.co.uk/html/history.html - Acesso em 20 de novembro de 2009.
} 
arquitetura, aumentar a consciência histórica dos espaços públicos, e como estes espaços serão experenciados e percebidos no futuro. Com bastante frequência, estas performances se configuram como pranks de situação. Um exemplo de que participei e que documentei foram as festividades do MayDay ${ }^{179}$.

Eram duas as celebrações mais populares da Inglaterra medieval: a festa de São João (no solstício de verão) e o MayDay. Originalmente, o primeiro de maio era uma homenagem celta e saxã ao deus do sol, Bel. Marcava o fim do inverno, quando a terra estava fértil novamente para o plantio. As comemorações incluíam jogos, máscaras, danças, bebida, comida e sexo. Era escolhida a May Queen, dentre as donzelas do vilarejo, que tinha a missão de zelar pela plantação durante a primavera. Robin Goodfellow (mito predecessor do Robin Hood) era o mestre de cerimônias da festa. Uma dança típica era o maypole, na qual solteiros dançavam ao redor de um poste repleto de fitas, entrelaçando-as. Outra brincadeira de gosto duvidoso era subir até o cume da colina mais próxima, atear fogo em uma roda de madeira e empurrá-la colina abaixo. Apesar da oposição da igreja anglicana, no começo do século XVIII, as celebrações em Londres chegavam a durar até 16 dias, durante os quais o comportamento desordeiro era praxe. Em 1708, por decreto governamental, as comemorações do MayDay se tornaram ilegais.

Os Space Hijackers convocaram, para primeiro de maio de 2008, uma manifestação contra os 300 anos de banimento da festa. Na região de Mayfair (lugar onde tradicionalmente se davam os festejos em Londres), cerca de duzentas pessoas se reuniram à moda antiga, com distribuição de frutas, doces, comidas e bebidas. Máscaras, trajes de época e maquiagem compuseram os figurinos. No tronco de tortura medieval foram postas pessoas com máscaras do primeiro ministro Gordon Brown, da princesa Camilla Parker Bowles e do então candidato conservador à prefeitura de Londres (hoje prefeito), Boris Johnson. Todos foram devidamente alvejados com esponjas molhadas. Na tradicional Maypole dance, várias donzelas encontraram seus

\footnotetext{
179 Registro que fiz em vídeo: SALVATTI, Fabio. London MayDay 2008, 2008. Disponível em http://www.youtube.com/watch?v=pjR9jCjRVkM.
} 
cavalheiros (e também várias donzelas encontraram suas donzelas e vários cavalheiros os seus cavalheiros). Para firmar a união, foi realizado um casamento coletivo em que qualquer pessoa podia casar com quantas pessoas ou coisas que quisesse por um dia. $\mathrm{O}$ som ficou por conta de uma bike sound system. Malabares, bolas de plástico, anarquistas, punks, crianças, senhores, hippies, muita cor, música, dança, cerveja, alguma chuva, algum sol, garantiram a diversão. A polícia metropolitana de Londres compareceu em grande número, mas ficou apenas observando a folia. Só foi protagonista no momento da escolha da May Queen. A coroa deveria ter ido para a cabeça do policial mais bonito do dia, mas ele se recusou a receber, tímido.
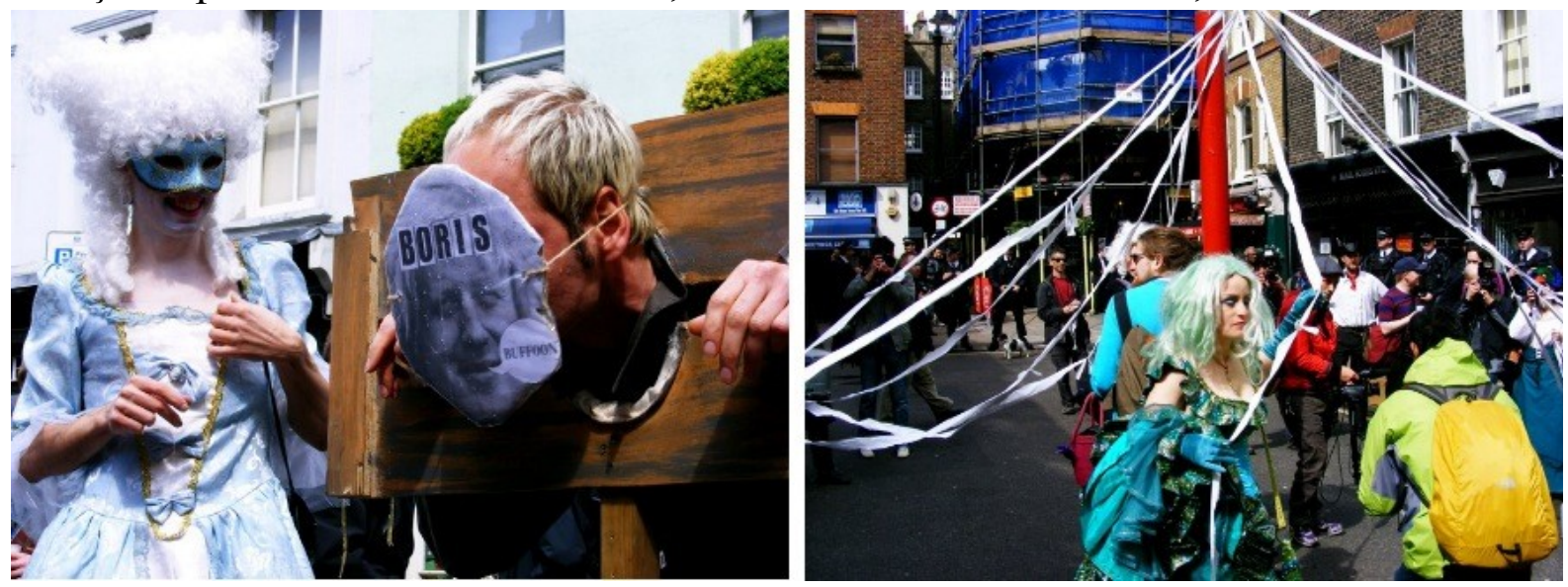

Figura 9: Esquerda: "Tortura" do candidato a prefeito Boris Johson na festa Mayday dos Space Hijackers, 01 de maio de 2008, Londres, Reino Unido. Direita: Dança do poste do Mayday.

Os Space Hijackers investem no desenvolvimento de tecnologia própria para a realização de seus pranks. Para a primeira de uma série de festas na Circle Line do metrô de Londres, em 10 de março de 1999, eles projetaram maletas que se transformavam em um bar, em um sound system, em luzes de discoteca ou em mesa de petiscos, dentre outros. As invenções do "departamento de equipamentos" são inusitadas e divertidas. Além das "maletas mutantes" (em outros pranks eles utilizaram maletas com escadas acopladas, maletas que se transformavam em skate e até uma mala de viagem que vira um quartel general com mesa, cadeiras, walkie-talkies, etc), eles criaram um terno que transmite rádio-pirata, sapatos com stencil readymade (basta pisar em uma tinta que a imagem ou o texto gravados na sola do sapato ficarão impressos na rua), botas com latas de spray acopladas no salto. Outras criações dos hijackers são de baixa tecnologia. Uma placa de "Pedestres, mantenham a esquerda", 
com uma linha branca dividindo a calçada longitudinalmente já é o suficiente para criar um engarrafamento de transeuntes.

O repertório dos "sequestros" incluem inúmeras frentes de pranks. A bienal DSEi (Defence Systems Equipment International, a maior feira de armamentos da Europa) tem sido alvo desde a edição de 2003. Nela, vários agentes dos Space Hijackers se disfarçaram de comerciantes e tentaram vender braços de bonecos para os negociantes de armas. Além do trocadilho (tanto "braço" quanto "armamento" são arm em inglês), os agentes afirmam que a intenção era demonstrar a natureza das armas vendidas na DSEi - aquelas armas geram sofrimento, mortes e mutilações. Em 2005, explorando as metáforas bélicas para o falocentrismo, os agentes voltaram à cena para demonstrar objetos de sex shops enquanto distribuíam panfletos com imagens de sado-masoquismo e textos como "há coisas mais interessantes para se fazer com botas de couro e uniformes", ou "você está preocupado com o desempenho da sua pistola?" com imagens alusivas à impotência sexual. Foi na edição de 2007 da feira, no entanto, que a criatividade dos hijackers se mostrou mais devastadora.

Insatisfeitos com o alcance limitado das ações em 2003 e 2005, quando foram contidos pela polícia e pela segurança do metrô, os Space Hijackers projetaram um ousado prank para a DSEi de 2007. A ideia era chamar a atenção para a feira e para os absurdos nela contidos. Por exemplo, o governo britânico investe 400 mil libras para a realização da feira, mais 4 milhões de libras em policiamento e segurança. "Independentemente de ações contra os direitos humanos, ou ao menos intenções, companhias de armamentos oferecem de navios de guerra a foguetes para a venda. Países em guerra (às vezes um contra o outro) são convidados para fazer a melhor oferta sobre os produtos (...)"180. Eventualmente, comerciantes oferecem armas proibidas por tratados internacionais, como minas terrestres, bombas de fragmentação e equipamentos de tortura. Mesmo assim, afrontosamente extraindo lucro da violência e da morte, a feira passa desapercebida por grande parte da população de Londres. O plano dos hijackers pretendia ridicularizar os negociantes de armas, evitar a contenção

\footnotetext{
180 http://www.spacehijackers.co.uk/html/projects/dsei07/index.html
} 
da polícia e explorar a cobertura da mídia. Após conversas regadas a cerveja, chegaram à conclusão do melhor caminho para tanto: "Nós precisamos de um tanque!"

Operacionalmente a ideia não era das mais fáceis. Era necessário levantar 5 mil libras para a compra de um tanque de guerra aposentado, mais um dinheiro extra para transporte, documentos (a intenção era que o veículo estivesse totalmente legalizado para transitar pelas ruas da cidade), reparos e demais gastos. A primeira ação foi a venda de camisetas com a frase "Eu ajudei a armar os Space Hijackers", logo abaixo de uma imagem de um tanque de guerra. Também foram feitas festas de arrecadação de recursos. Isto angariou, além de dinheiro, vários adeptos para a causa. Dentre eles, o coletivo Artists Anonymous (Artistas Anônimos) ${ }^{181}$, que concordou em financiar metade do projeto. Após a certeza da aquisição do tanque, o passo seguinte foi uma conferência de imprensa explicando o prank, seus objetivos e métodos. Provocativamente, os agentes acrescentaram que diminuiriam a velocidade do tanque "se policiais colocarem uma flor no canhão do tanque; se policiais sentarem-se em protesto em frente do tanque; (...) se policiais subirem em um andaime, ao estilo Reclaim the Streets; se policiais acorrentarem-se ao tanque" ${ }^{182}$. Ou seja, já que os Space Hijackers teriam a força do armamento, eles estariam dispostos a negociar caso os policiais se convertessem em manifestantes e adotassem táticas de protesto.

Em seguida, uma complicada logística foi implementada para deslocar, reparar e legalizar o tanque. A polícia tomou conhecimento tão logo o tanque foi descarregado pelo caminhão de carga, e desde então ficou espreitando a movimentação dos hijackers, que, inclusive, chegaram a desconfiar que estavam com telefones grampeados, tal era a coordenação com que a polícia interceptava suas ações. Dois dias antes da abertura da feira, por exemplo, os hijackers decidiram mover o tanque de um estacionamento para outro, a fim de escapar da vigilância. Mesmo executando a ação na madrugada, os policiais apareceram no mesmo momento para dificultar a manobra. A paranoia era tanta que os hijackers decidiram elaborar um plano B, que

http://artists-anonymous.com//

http://www.spacehijackers.co.uk/tank/press/hijacker_statement.html 
permaneceu secreto até o dia do evento. Enquanto isso, no novo estacionamento, o tanque foi submetido a retoques, com luzes, sound system e decoração de guerra.

Às $12 \mathrm{~h} 30$ de 11 de setembro de $2007^{183}$, o tanque batizado de Fredom (brincadeira com a palavra freedom, liberdade. O nome anterior do tanque era Fred) estava pronto para se dirigir à feira. Os hijackers tomaram o cuidado de estacionar um caminhão de mudanças em frente à saída do estacionamento, para que não pudessem ser bloqueados com uma van, o que foi exatamente o que a polícia tentou fazer. No entanto, o dono do estacionamento, cúmplice dos hijackers, deitou em baixo da van policial, gritando "eu não aguento mais estes anarquistas! Eu quero que eles saiam do meu estacionamento agora e vocês não vão bloqueá-los!”. Os policiais concordaram em escoltar o tanque até a entrada da feira, desde que passasse por uma inspeção provando que não ia causar danos às ruas da cidade. Uma multidão de manifestantes já se aglomerava nas proximidades do tanque, quando o telefone soou anunciando que o plano B encontrava-se em ação. Um porta-voz dos Space Hijackers subiu no tanque para anunciar:

\begin{abstract}
"Senhoras e senhores, receio ter más notícias. Parece que a polícia está fazendo de tudo para nos atrasar e impedir que o nosso veículo, ainda que perfeitamente legalizado, possa transitar pelas ruas. (...) Basicamente, senhoras e senhores, não desejamos mais tomar o seu tempo, já que a maior feira de armas do mundo está acontecendo e a polícia parece mais interessada em barrar protestos legítimos do que barrar algumas das pessoas mais corruptas e inescrupulosas do planeta. (...) Nós acabamos de receber um telefonema de dois dos nossos agentes que não puderam estar conosco hoje. Aparentemente, nosso SEGUNDO TANQUE, de 60 toneladas, está a caminho da feira. Nós sugerimos que vocês sigam nossos agentes e o encontrem lá" 184 .
\end{abstract}

Em 2 minutos, 90\% dos policiais desapareceram do local, em busca do segundo veículo. Logo o encontraram, um enorme tanque que havia sido das Nações Unidas e que os Space Hijackers haviam alugado via internet ${ }^{185}$. Incapaz de bloqueá-lo, a polícia concordou em escoltá-lo até o local da feira. Lá chegando, o tanque-pirata foi saudado pelos manifestantes que ali estavam. O porta-voz dos hijackers mais uma vez tomou a

\footnotetext{
183 Na minha modesta opinião, um dia de extremo mal gosto para a realização de uma feira de armas.

184 http://www.spacehijackers.co.uk/html/projects/dsei07/tuesday.html

185 Caso haja curiosidade, o site http://tanks-alot.co.uk/ tem tanques para festas infantis, eventos, casamentos, filmagens e até um tanque-limosine para festinhas particulares.
} 
palavra, anunciando que, após anos de luta contra os negociantes de armas e a polícia, o coletivo finalmente percebeu que estava errado. "Se os negociantes de armamentos podem vir a Londres e vender armas sem se preocupar em como estas armas serão usadas, quem somos nós para discordar?” Declarou, então, aberto um leilão para a venda do tanque em que estavam. Não importava se o comprador iria esmagar um carro de polícia ou invadir o prédio em que se realizava a feira; assim como os negociantes, os Space Hijackers se isentavam das consequências. Uma aposta de 50 dólares venceu o leilão, para a preocupação dos policiais que realizavam a escolta. No entanto, os bike sound systems voltaram a tocar e o protesto se transformou em uma enorme celebração.
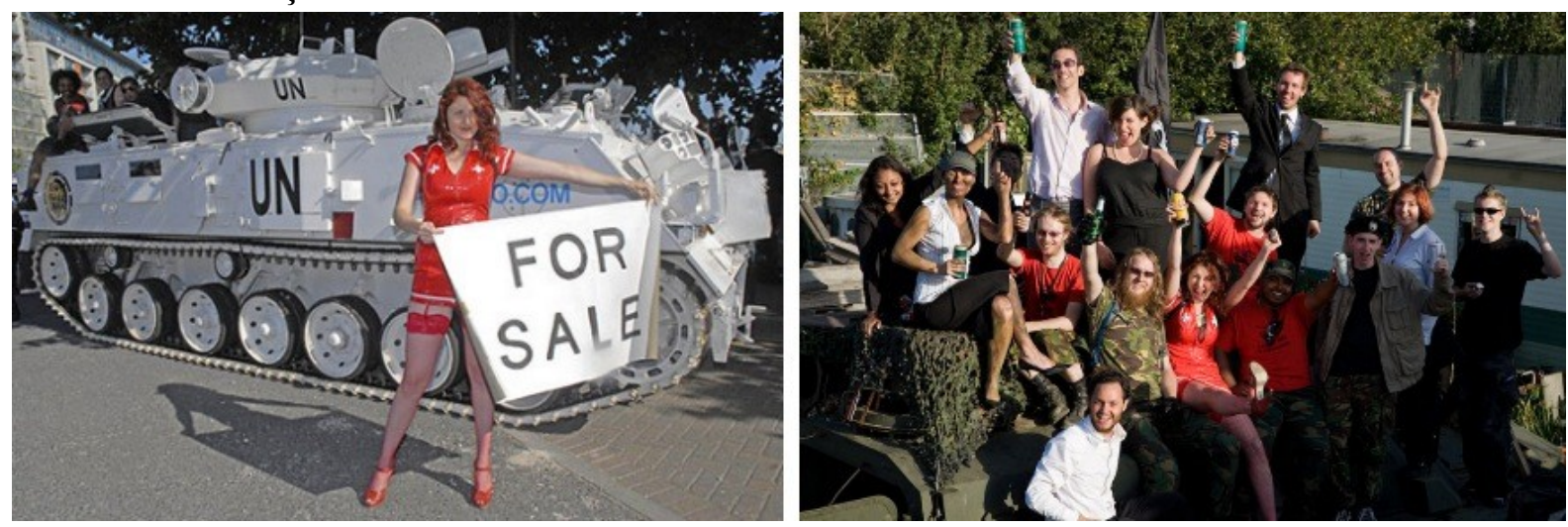

Figura 10: Esquerda: Loolie, dos Artists Anonymous, participando do leilão do tanque de guerra promovido pelos Space Hijackers, 11 de setembro de 2007, Londres, Reino Unido. Direita: Space Hijackers comemorando o sucesso de sua empreitada.

Apesar da metodologia de alguns dos pranks (como este dos tanques) dos hijackers exigir infra-estrutura e grau de organização e de mobilização muito grandes, outras ações dos hijackers compartilham a simplicidade do Street Training no jogo com o espaço urbano. Ao reivindicarem o direito a um espaço não-colonizado, ausente de controle comercial, estatal ou urbanístico, os hijackers e os street trainers manifestam características das performances dos letristas e dos situacionistas com a cidade, "elevar a vida à promessa contida na arte".

Se nos pranks do MayDay, das festas no metrô e dos protestos contra a DSEi isso já é claro, o parentesco com a performatividade do Street Training fica ainda mais evidente no passeio turístico organizado pelos Space Hijackers em 13 de julho de 2003. A proposta era a de um simples trajeto por pontos culturalmente interessantes de 
Londres (o Instituto de Arte Contemporânea, o Waterloo Place, os bares de Pall Mall, o clube de viajantes, a antiga casa de Ada Lovelace, filha do Lord Byron, etc), respeitando duas regras simples: 1- Evitar tocar o chão; e 2- Se tocar o chão for necessário, deve-se prender a respiração até que se possa deixar de tocá-lo. Uniformizados com camisetas vermelhas, 25 exploradores trilharam o percurso, atentos às regras. Mesmo quando interpelados pela polícia, responderam às questões sem colocar os pés nos chão. No final do trajeto, exaustos, suados e sujos, se renderam a uma cerveja no Old Red Lion Pub.

A noção de "sequestro" subjacente em todas as performances dos Space Hijackers (e também no Street Training) está sustentada em um posicionamento que considera ilegítima tanto a invasão econômica das corporações no espaço público quanto a ostensiva vigilância tecnológica (câmeras de segurança, equipamentos de biometria, etc) e policial do estado. Os "sequestros" promovem uma emancipação momentânea em relação a este poder econômico e político vigente nas cidades. Fundam espaços insurgentes, que o filósofo Hakim Bey chamou de Zonas Autônomas Temporárias (conhecidas pela sigla TAZ, do inglês Temporary Autonomous Zones). Em vez de pretender uma trajetória de revolução que tome o poder e se torne novamente um estado opressivo, as TAZ buscam momentos de insurreição, de levante, "experiências de pico" de intensidade extraordinária. A TAZ é "uma operação de guerrilha que libera uma área (de terra, de tempo, de imaginação) e se dissolve para se re-fazer em outro lugar e outro momento, antes que o Estado possa esmagá-la" ${ }^{186}$. A característica fugidia da TAZ é decorrente de sua organização não-hierárquica, espontânea e rizomática. Ela se aproveita das fissuras do poder onipresente para permanecer invisível e imprevisível para o estado. Assim que a TAZ é detectada, desaparece para surgir em outro lugar, escapando de tentativas de contenção.

A literatura de Bey ressalta os aspectos lúdicos dos levantes, uma cultura festiva que emerge destacada ou escondida dos "gerentes do nosso lazer", que unificam mercadoria e espetáculo. “'Lute pelo direito de festejar' não é, na verdade, uma paródia

186 BEY, Hakim. TAZ - Zona autônoma temporária. São Paulo: Conrad, 2001. Col. Baderna, p. 17. 
da luta radical, mas uma nova manifestação dessa luta" ${ }^{187}$. É possível identificar aí a influência que Bey exerce nos ativistas que adotam a prática do prank: Reclaim the Streets, Space Hijackers, Street Training, em muitos dos exemplos até aqui citados os ecos da TAZ são explícitos ou implícitos.

No coletivo Delinquentes, Inconsequentes e Dementes (DID) a presença de Bey é ainda mais forte. O coletivo foi atuante em Curitiba, principalmente entre 2003 e 2005, e sessenta de seus ataques foram narrados no Manual Prático de Delinquência Juvenil (volumes I e II) ${ }^{188}$. O DID adotou várias modalidades de pranks, mas pode-se dizer que a mais frequente foi a dos pranks de armadilha, geralmente envolvendo a invasão de um espaço privado para sua realização. Assumidamente equilibrando-se entre o ativismo e o vandalismo, o grupo adota uma redação despojada nos relatos, recorrendo à terminologia retirada de Hakim Bey.

Apesar de não ter nenhuma pretensão teórica, a descrição dos ataques por Ari Almeida (um dos integrantes do DID) por vezes reivindica o "distúrbio cotidiano", por outras, o "terrorismo poético" (TP). A respeito deste último, Bey escreveu:

Dançar de forma bizarra durante a noite inteira nos caixas eletrônicos dos bancos. Apresentações pirotécnicas não autorizadas. Land-art, peças de argila que sugerem estranhos artefatos alienígenas espalhados em parques estaduais. Arrombe apartamentos, mas, em vez de roubar, deixe objetos Poético-Terroristas. Sequestre alguém \& o faça feliz. (...) A arte-TP também pode ser criada para lugares públicos: poemas rabiscados nos lavabos dos tribunais, pequenos fetiches abandonados em parques \& restaurantes, artexerox sob o limpador de pára-brisas de carros estacionados, slogans escritos com letras gigantes nas paredes de playgrounds, cartas anônimas enviadas a destinatários previamente eleitos ou escolhidos ao acaso (fraude postal), transmissões de rádio piratas, cimento fresco

A reação do público ou o choque-estético produzido pelo TP tem de ser uma emoção pelo menos tão forte quanto o terror - profunda repugnância, tesão sexual, temor supersticioso, súbitas revelações intuitivas, angústia dadaísta - não importa se o TP é dirigido a apenas uma ou várias pessoas, se é "assinado" ou anônimo: se não mudar a vida de alguém (além da do artista), ele falhou. ${ }^{189}$

\footnotetext{
$187 \quad$ Ibid. p. 26.
}

188 Os textos foram originalmente publicados no blog www.delinquente.blogger.com.br e então compilados nos Manuais Práticos, que estão à disposição para download no mesmo blog. Um pequeno excerto está anexado a esta tese.

189 BEY, Hakim. Caos - terrorismo poético e outros crimes exemplares. São Paulo: Conrad, 2003, pp. 13-14. 
Quando postos em prática pelo DID, o terrorismo poético assume a forma de arriscados, inusitados e divertidos pranks, regidos pela total recusa à autoridade, à legislação estatal, às convenções sociais e ao politicamente correto. Como afirma Ari Almeida, "temos tudo pra dar errado. Somos um caco de vidro na areia da praia, esperando alguém pisar em cima" ${ }^{190}$.

Esta marginalidade assumida reflete a metodologia dos ataques do grupo: eles não divulgam a realização de futuros ataques, não mantém registro em foto ou vídeo, não tem outra divulgação a não ser o blog, cujos relatos são posteriores aos ataques. Quando, em 2004, convidei Ari para um debate sobre terrorismo poético ${ }^{191}$, ele se recusou a aparecer em fotos. Ele exige que sua invisibilidade não seja violada ${ }^{192}$.

A cautela se explica pela natureza ilegal e semi-vândala de suas ações. Por exemplo, no ataque de número 26 , intitulado "A madame, os poodles, a cegueira \& o castigo" ${ }^{193}$, o DID invadiu a casa de uma senhora burguesa que, passeando com seus poodles, havia menosprezado uma pedinte alguns dias antes. A cena, testemunhada por um dos integrantes do grupo, gerou a indignação suficiente para a organização do prank. Para invadir a casa, outro integrante seduziu a empregada doméstica que lá trabalhava, e com ela conseguiu informações suficientes para mapear a arquitetura e a rotina do local. Na noite do ataque, o grupo passou pelo quintal de casas vizinhas a fim de chegar na casa-alvo. A entrada se deu pelo telhado, com muita cautela. Já dentro da residência, os membros do grupo utilizaram seu material de ataque. Na comida dos cachorros, puseram bilhetes com as frases "Seus cachorros comem enquanto irmãos passam fome"; "Esta comida foi desenvolvida para cachorros de todas as raças mas os donos que pensam como Hitler podem consumir sem contra-indicações"; "Se não souber ler pergunte à sua arrogante dona"; "Comam tudo, crianças, para não sobrar nada aos mendigos que reviram a lixeira"; "Esta ração deixa o pêlo macio e o latido mais forte contra os pobres de sua rua". Nos retratos nas paredes, colaram bigodes e

\footnotetext{
190 ALMEIDA, Ari. op. cit., p. 54.

191 Que fez parte do projeto Amigos dos Amigos, organizado por mim, pela atriz Ana Clara Fischer e pela performer Margit Leisner no segundo semestre de 2004 no Centro Cultural Teatro Guaíra, em Curitiba.

192 Os próprios nomes dos Delinquentes podem ser falsos.

193 Excerto anexado a esta tese.
} 
chifres. além de escrever com giz: "Os Mendigos Invisíveis Estiveram Aqui". "A senhora foi selecionada pra pagar os pecados da burguesia". "Tome cuidado com os Mendigos Invisíveis". "Dinheiro não pode comprar felicidade, mas pobreza não pode comprar nada". Com óleo queimado, escreveram na grama do jardim: "A senhora não entendeu, mas isso é maravilhoso".

O planejamento e a execução deste ataque exemplificam características da modalidade de prank de armadilha. A pessoa-alvo do prank (neste caso, a dona da casa) só percebe o que aconteceu após a ação do grupo, e não durante. Sua relação é indireta, ou seja, não se dá na presença dos agentes, mas sente os efeitos desta presença a posteriori.

Quanto à disputa pelo espaço, os DID apontam caminhos ainda mais radicais. As invasões para preparação de armadilhas são, quase na sua totalidade, em espaços privados. Outros pranks são em espaços privados mas com circulação pública (lojas, caixas eletrônicos, shopping centers, igrejas, restaurantes). Como a proteção da propriedade privada é a tônica da nossa legislação, quase todo prank dos Delinquentes é marcado pela infração de uma (ou mais) leis.

Quando apostam na criação de um prank de situação, mantém a insubmissão às convenções e a crítica anárquica. No ataque número oito, "A gurizada Big Mac Feliz"194, após ter encontrado cento e cinquenta reais por acaso na rua, os DID decidiram gastá-los no McDonald's, mas de um jeito "que [os donos do estabelecimento] pagariam o triplo para que não gastassem a grana lá". A ideia foi convocar vinte meninos de rua e ir até um shopping center para comprar um McLanche Feliz para cada. Depois da tentativa frustrada de entrar com o grupo de crianças em dois shopping centers, no terceiro a tática adotada revelou-se eficaz: os meninos entraram dois a dois. Na fila do McDonald's, os frequentadores do shopping mostraram-se incomodados com a presença das crianças e foram procurar outras lanchonetes. Os meninos tinham o dinheiro contado para o seu lanche, apesar de nem saber direito como pedi-lo. Após a refeição, as crianças ainda aproveitaram para entrar

194 Também em anexo. 
em lojas de brinquedos e jogos eletrônicos, um universo do qual elas estão frequentemente excluídas. A segurança do shopping esteve prestes a intervir, mas os DID conseguir reunir a turma e, no final, todos se reuniram na praça em frente ao shopping para um festa junina improvisada.

A situação experimentada pelas crianças de rua, pelos membros do DID, pelos funcionários e seguranças do shopping e pelos consumidores exigiu de todos uma espécie de posicionamento. Desestabilizados de sua conduta usual, todos precisaram tomar atitudes improvisando sobre o inusitado da experiência. E isto pôde revelar os valores, as crenças, os preconceitos e os códigos que sustentam esta mesma chamada "conduta usual", e, quem sabe, passá-los por um reexame. Esta foi a contribuição estética e política deste prank de situação.

Os pranks dos DID nasciam de um animado brainstorming dos participantes, sem um programa a ser cumprido, ou uma bandeira específica a ser levantada. Se, por um lado, o critério de seleção era geralmente a adrenalina que a ação exigiria e a diversão que garantiria, por outro, a indignação contra as normas e instituições determinava que os pranks permanecessem altamente políticos. Críticas à televisão, às corporações, à cultura do automóvel, à exploração de animais, à religião, ao consumismo, ao apartheid social, à ditadura da beleza, ao puritanismo, ao sistema financeiro e à cultura do trabalho fizeram parte do repertório temático dos ataques.

A frase-gafe do boxeador Maguila, "o trabalho danifica o homem", serviu como inspiração para o ataque número vinte e nove, "O Nonsense, Meu Nego, No Combate Ao Desemprego"195. Para conseguir o pagamento das vagas temporárias de trabalhossem-sentido que o DID pretendia criar, um dos membros aplicou um golpe em uma senhora: convenceu-a de que o sobrinho precisava de um dinheiro emprestado para arrumar o carro. Os DID então rumaram para um bairro da periferia de Curitiba, onde esticaram a faixa "Há vagas. Serviço fácil. Dinheiro à vista". Os frequentadores do boteco próximo onde a faixa foi esticada ficaram curiosos com o anúncio. Quando souberam que, para ganhar cinco reais, teriam que cavar um buraco, dar vinte e três

195 Também em anexo. 
voltas ao redor de um cavalete repetindo "quem inventou o trabalho não tinha o que fazer" e depois tapar o buraco aberto, ficaram desconfiados. Depois do primeiro realizar a tarefa e embolsar o dinheiro, para a gargalhada dos demais, mais voluntários apareceram. O sucesso da ação foi tal que os Trabalhadores Sem Sentido rapidamente esgotaram o caixa dos Delinquentes. Eles consideram, inclusive, que a senhora enganada para financiar o prank ficaria orgulhosa da aplicação dos recursos.

Ainda que não se demorem demasiadamente no assunto, os DID tentaram, em alguns relatos e no prólogo do Manual Prático de Delinquência Juvenil, comparar seus métodos, estratégias e objetivos tanto com os da prática ativista quanto com os da prática artística contemporâneas. A respeito do novo ativismo global, eles julgam que "encontra-se num beco sem saída: A 'Geração de Seattle' encontra-se presa à sua própria mitologia. (...) Precisamos de Novas Táticas. Teatro Secreto. Loucos Subversivos agindo na calada da noite. Vândalos \& Bárbaros criando Novas Situações que arrebentem as correntes da Realidade Consensual" ${ }^{196}$. Estas "novas situações" são espontâneas, insurgentes, locais, invisíveis, subreptícias, afastadas da atenção dos meios de comunicação de massa ${ }^{197}$, exatamente como nas TAZ de Hakim Bey. Outra característica reivindicada pelos pranks dos Delinquentes é um humor anárquico e iconoclasta. "O humor salvará o mundo. Uma das regras básicas do nosso grupo é nunca nos levarmos a sério demais. Isso já confirma a nossa contribuição com pelo menos um pouquinho do humor que salvará o mundo. A gente, pelo menos, se diverte" ${ }^{\prime 198}$.

Em relação à arte, mesmo que a posição predominante seja de transgressão, algumas declarações dos DID a respeito da pretensão artística parecem contraditórias. "Chamar alguém de artista plástico hoje em dia equivale a xingar os parentes do sujeito até a oitava geração ascendente. Me chame de filho da puta, mas não me chame de artista. A arte encontra-se mercantilizada, afetada, elitizada, enfim, totalmente

\footnotetext{
196 ALMEIDA, Ari. op. cit., p. 2.

197 Os DID afirmam que "Ação de impacto é coisa pra rato de mídia. Estamos fora, não gostamos de aparecer na foto". Ibid. p. 91.

198 Ibid. p. 72.
} 
corrompida de sua original função transgressora" ${ }^{199}$. Apesar desta visão claramente desaprovadora, em outros pranks eles chamam pra si a tarefa vanguardista (e, de certa forma, anti-artística ${ }^{200}$ ) de devolver a arte ao cotidiano, ou de fazer com que a vida cotidiana se equipare ou seja melhor do que o projeto contido na arte: "se somos a ralé dessa sociedade porca, pelo menos temos a arte em nossos corações; e o que é melhor: arte não corrompida"201; "sim, podíamos criar situações que subvertessem a rotina cotidiana e turbinasse a realidade banal com um pouco mais de arte" ${ }^{202}$. É nítido o contágio destas ideias com a anarquia ontológica de Hakim Bey e com o projeto situacionista de superação da arte.

Acredito, ou ao menos gostaria de propor, que a única solução para a "supressão e realização" da arte está na emergência da TAZ. (...) Eu sugiro que a TAZ é o único "lugar" e "tempo" possível para a arte acontecer pelo mero prazer do jogo criativo, e como uma contribuição real para as forças que permitem que a TAZ se forme e se manifeste. (...) Na TAZ, arte como uma mercadoria será simplesmente impossível. Ao contrário, a arte será uma condição de vida. (...) a remoção de todas as barreiras entre artistas e "usuários" da arte tenderá a uma condição na qual "o artista não é um tipo especial de pessoa, mas toda pessoa é um tipo especial de artista". ${ }^{203}$

Em outro trecho, mais normativo, Bey orienta a manutenção da característica insurgente, autônoma e camuflada do Terrorismo Poético, em direção a uma categoria artística não reconhecível e radical, aproximada do crime, que certamente ecoa nas ações dos DID:

Não faça TP para outros artistas, faça-o para aquelas pessoas que não perceberão (pelo menos não imediatamente) que aquilo que você fez é arte. Evite categorias artísticas reconhecíveis, evite politicagem, não argumente, não seja sentimental. Seja brutal, assuma riscos, vandalize apenas o que deve ser destruído, faça algo de que as crianças se lembrarão por toda a vida. (...) Arte como crime; crime como arte ${ }^{204}$.

\footnotetext{
199 Ibid. p. 9.
}

200 O professor Roger Taylor sustenta que a arte como conceito exclusivo e transcendente de valor foi uma invenção da aristocracia. A burguesia se apropriou dele para conferir uma mística especial a certos aspectos de sua vida de consumo, classificando suas preferências como "arte" (cf. TAYLOR, Roger. Arte, inimiga do povo. São Paulo: Conrad, 2005). Certamente a discussão histórico-filosófica do forjamento do conceito de arte é bastante vasta, e não é o foco prioritário desta tese. Neste momento basta considerar que uma concordância com a opinião de Taylor parece subjacente nos pranks dos DID. 
O posicionamento ambíguo em relação ao universo da arte não é privilégio dos DID. Vários dos grupos aqui abordados não se intitulam "artistas", ainda que, com alguma recorrência, identifiquem aspectos "artísticos" de suas ações. Os anarquitetos dos Space Hijackers, por exemplo, lamentam que "sempre seja impossível posicionar [seus] trabalhos que existem fora do jeito ARTE de fazer as coisas dentro de uma moldura artística" ${ }^{205}$. O Street Training assume para si o status de "arte marcial", mas somente pela conotação de treinamento físico e psicológico que o termo carrega.

Independente do posicionamento individual que cada grupo selecionado como exemplo adote em relação à produção de arte, é relevante perceber que vários dos coletivos que adotam os pranks como alternativa de exercício estético e político fazem, expressamente ou não, uma distinção entre arte política e ativismo artístico. Beka Economopoulos, do coletivo Not an Alternative, considera que

Há uma diferença entre estetizar a política e politizar a estética. No primeiro caso, vemos como a arte pode funcionar como design, um símbolo ou uma forma para galvanizar uma comunidade ou uma cultura, recrutar pessoas, manter espíritos animados e a energia alta, expressar a política. Politizar a estética é quando pensamos em inscrever a política na estética, olhando para os símbolos, narrações e eventos na história, que existiram e que estão na consciência cultural, e atuar sobre eles. ${ }^{206}$

Brian Holmes, por sua vez, considera que o ativismo artístico "acontece ao mesmo tempo que uma ação direta, como parte de um processo organizacional cuja finalidade não é criar arte, mas realizar um gesto em público, e a arte está na maneira pela qual este gesto vai aparecer" ${ }^{207}$. Seguindo o mesmo princípio, os pranks dos grupos aqui apresentados não pretendem necessariamente ter uma finalidade artística, mas acabam adotando meios artísticos (performativos, sobretudo) para sua realização.

No entanto, não é difícil identificar grupos ou ações cuja preocupação prioritária seja a produção de arte propriamente dita e que adotam os pranks como estratégia de engajamento. Gostaria de ilustrar esta afirmação com dois breves

\footnotetext{
205 http://www.spacehijackers.co.uk/html/projects/hull.html

206 Em entrevista para o documentário de ARTIGAS, Xavi e MARTIN, Leónidas. Metropolis - Arte y activismo. Documentário veiculado pela emissora espanhola TVE $2 \mathrm{em} 28$ de fevereiro de 2010. Disponível em http://www.rtve.es/mediateca/videos/20100301/metropolis---arte-activismo/707244.shtml. Acesso em 10 de abril de 2010.

207 Entrevista em anexo.
} 
exemplos que pude acompanhar pessoalmente. O primeiro deles foi "Eu pensei que todo mundo fosse filho de Papai Noel", performance ocorrida na cidade de Curitiba, em dezembro de 2003. Organizada pelo Grupo Processo de Artes Mundiais, com direção de Adriano Esturilho, a performance era uma paródia de uma passeata de rua, na qual diversos papais noéis faziam reivindicações trabalhistas em megafones (permissão para trabalhar com trajes tropicais no verão brasileiro, autorização para cortar a barba, uma mamãe noel que protestava contra o patriarcado, um duende, contra a divisão de classes, etc). O cortejo terminava com um "enterro simbólico" dos papais noéis na frente de um McDonald's. O prank de situação era caracterizado pela ressignificação jocosa das passeatas estudantis ou sindicalistas, parodiando seus cantos e palavras de ordem, adotando o mesmo "trajeto padrão" no centro de Curitiba. O nonsense das reivindicações dos papéis noéis expunha a saturação e o esgotamento do modelo formal das passeatas como instrumento de agitação política.

O segundo exemplo, carinhosamente apelidado de "peça panfletária", ocorreu ao longo dos dez dias do Festival de Teatro de Curitiba em 2001, durante os quais membros da Cia EmCômodo Teatral ${ }^{208}$ e do Grupo Processo de Artes Teatrais ${ }^{209}$ distribuíram pequenos panfletos que satirizavam a overdose de divulgação no referido Festival. Os 38 mil panfletos tinham uma pequena pomba desenhada e uma frase enigmática ou provocativa. Eram 18 frases diferentes, dentre elas: "Felicidade é caber em um vestido P", "Acabe com ela antes que ela acabe com você", "Essa não, é sabão", "Bom mesmo era o Getúlio", "Passe para sete pessoas", "Arroz eu como em casa", "Mais uma obra do governo do estado do Paraná", "Vamos reconstruir o muro de Berlim". Não havia nenhuma outra informação, o que deixava confusos os transeuntes, então acostumados com panfletos que divulgavam data, horário e local dos espetáculos em cartaz no Festival. "Nos dez dias em que a Peça panfletária existiu

\footnotetext{
208 Formada, na época, por mim, Fabio Kinas e Lucianna Raitani.

209 Formado, na época, por Adriano Esturilho, Carolina Maia, Andrew Knoll, Henrique Saidel e Giórgia Conceição. Hoje estes dois últimos fazem parte da Companhia Silenciosa.
} 
oficialmente, fundou-se um controverso, porém fértil, espaço-tempo de troca e relação, um enclave no não-lugar da comunicação publicitária" ${ }^{210}$.

Mesmo nestas práticas que se assumem prioritariamente artísticas (e não reivindicam o status de ativistas, o que é o oposto da maioria dos exemplos examinados até aqui), o engajamento político é evidente. No entanto, é possível identificar estratégias que utilizam o prank em direções que indicam um engajamento político em um primeiro momento, mas que acabam cooptadas, absorvidas pela indústria cultural, e perdem sua potencialidade crítica.

É o caso dos flash $\operatorname{mobs}^{211}$, uma das demonstrações mais impressionantes da conversão de comunidades virtuais em comunidades físicas. Em julho de 2004, a expressão "flash mob" entrou para o Oxford English Dictionary como sendo "uma reunião pública de desconhecidos, organizada via internet ou celular, que realiza um ato sem sentido e então se dispersa" ${ }^{212}$. Tudo começou pouco mais de um ano antes, no final de maio de 2003, quando o editor da Harper Magazine, Bill Wasnik encaminhou para alguns de seus amigos um e-mail que ele havia recebido do endereço themobproject@yahoo.com. Nele havia um convite para participar de um projeto que criava uma multidão inexplicável em determinados pontos de Nova York por dez minutos ou menos. Pedia também que o destinatário encaminhasse o mail para pessoas que julgasse que pudessem querer participar. A mensagem ainda continha uma seção de "perguntas frequentes", resumida a apenas uma: "Por que eu gostaria de me juntar a uma multidão inexplicável?", com a resposta "Milhares de pessoas estão fazendo isso".

Wasnik tinha ele mesmo criado a conta de e-mail do projeto mob, para dar alguma credibilidade e incentivar o encaminhamento do e-mail. No entanto, ele

210 SAIDEL, Henrique. "Infiltrações silenciosas: relações nada comportadas entre artista, espaço público e espectador" in RAUEN Margarida Gandara (Margie) (org.). A interatividade, o controle da cena e o público como agente compositor. Salvador: EDUFBA, 2009, p. 67. O cruzamento entre linguagem publicitária e pranks será abordado no próximo subcapítulo.

211 Uma tradução literal do termo seria "multidão instantânea".

212 WASIK, Bill. "My crowd: or, phase 5: a report from the inventor of the flash mob". Disponível em http://goliath.ecnext.com/coms2/gi 0199-5337724/My-crowd-or-phase-5.html - Acesso em 18 de janeiro de 2010. 
permaneceu semi-anônimo até março de 2006 (concedia entrevistas sobre os flash mobs, mas identificava-se apenas como "Bill"), quando publicou um artigo na Harper, avaliando o "experimento social" que ele havia criado.

A hipótese que o projeto mob assumia era de que a cultura de Nova York era comprometida com um "fetiche da cena", ou seja, que o apelo do consumo de shows, exibições, peças de teatro derivava menos do trabalho em si do que das oportunidades sociais que aquele trabalho poderia engendrar. Wasnik considerava isto particularmente verificável no caso da cultura hipster ${ }^{213}$, aquela cujo interesse em arte, moda, alimentação e conduta pessoal pretende se afastar do mainstream, preferindo rótulos como "independente" ou "alternativo" (mas que, paradoxalmente, funciona como uma vanguarda lançadora de modas). Parodiando este desejo de fazer parte de uma cultura underground, o projeto do flash mob consistia em promover uma "cena" em si mesma, a reunião de pessoas constituía o propósito final, cuja adesão só era justificada "porque outras pessoas estão fazendo". "Não apenas o flash mob era uma moda vazia; na sua própria forma (agregação sem sentido e depois dispersão) tinha a intenção de ser uma metáfora para a rasa cultura hipster que a gerou" 214 .

O primeiro mob foi marcado para o final da tarde do dia 03 de junho de 2003. As pessoas deveriam chegar à loja Claire's Acessories às 19h24 precisamente, e percorrer a loja, dizendo aos vendedores que estavam apenas "dando uma olhada", até que, às $19 \mathrm{~h} 31$, todos deveriam retirar-se da loja e continuar seus afazeres. O plano foi frustrado pela aparição da polícia, que bloqueou a entrada da loja com uma van. O jeito foi esperar até 17 de junho, para o mob número dois. Para evitar um eventual novo bloqueio, o e-mail de convocatória indicava quatro diferentes bares (aos quais cada um deveria se dirigir de acordo com o mês de nascimento) nos quais seria revelada a localização final do ataque. No dia marcado, então, após receber as instruções finais nos bares, os aproximadamente duzentos participantes do mob se dirigiram até o departamento de tapetes da loja Macy's, e informaram ao 
impressionado vendedor que todos viviam juntos em uma comunidade em Long Island, faziam compras juntos, e estavam interessados em adquirir um "tapete do amor”. Às 19h37, dez minutos após a chegada, todos deveriam dispersar. Este foi o primeiro flash mob bem-sucedido.
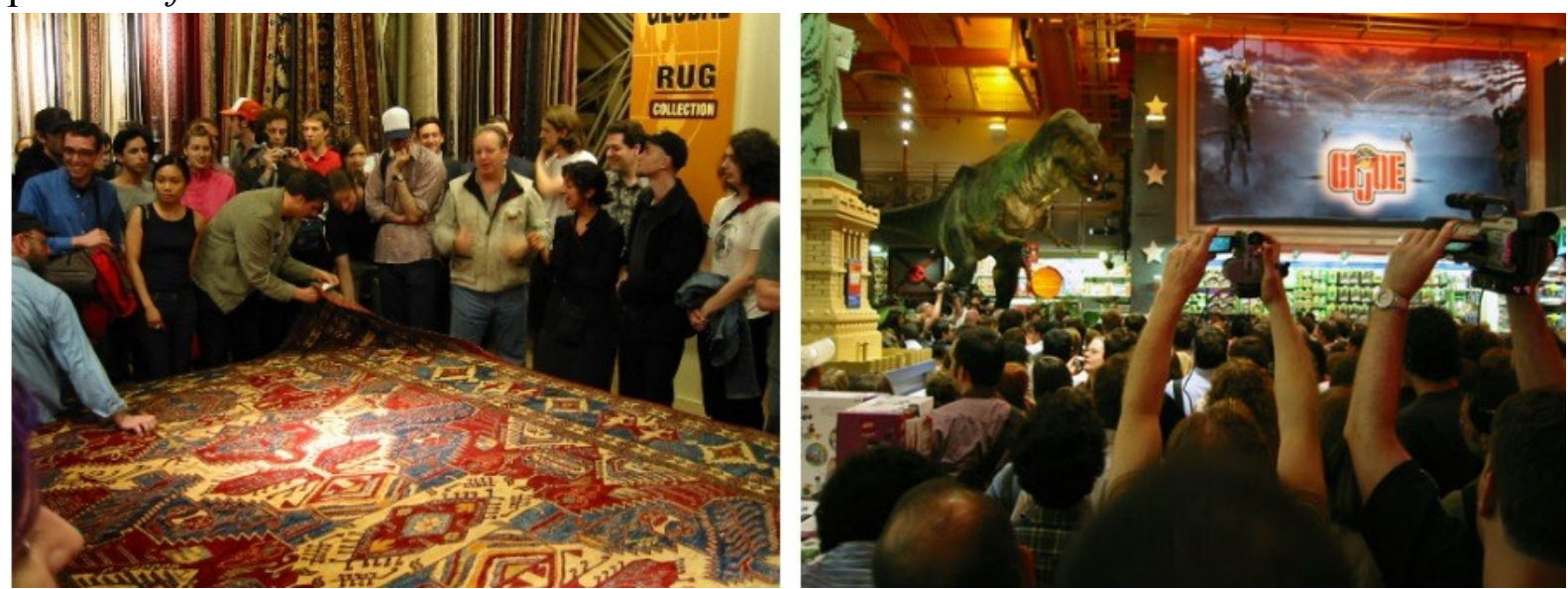

Figura 11: Esquerda: Flash mob \#2, na loja Macy's, 17 de junho de 2003, Nova York, EUA. Direita: Flash mob \#6, na loja Toys $R$ Us, 08 de agosto de 2003, Nova York, EUA.

De duas em duas semanas, até o mês de setembro, o projeto mob original organizou oito flash mobs. Dentre os roteiros, os mobbers realizaram uma imitação coletiva de pássaros no Central Park, uma excursão turística a uma loja de sapatos, uma adoração religiosa ao grande tiranossauro rex robotizado da loja Toys " $\mathrm{R}$ " Us e uma falsa fila para a compra de ingressos para o show dos Strokes (então uma banda adorada pelos hipsters).

Rapidamente os flash mobs se espalharam pelos Estados Unidos, Canadá e pela Europa, e se converteram, efetivamente, em uma poderosa moda. Os jornalistas colaboraram no julgamento dos mobbers. Grande parte deles os classificava como “entediados, sem objetivo e narcisistas; (...) vítimas de uma curta moda que será esquecida com a mesma velocidade com que virou moda" ${ }^{215}$.

[Uma multidão] dançando ao som de seu MP3 player, em público, é uma piada interna e cheira apenas vagamente a uma instalação artística. "Ei, olhem para nós! Nós somos loucos! Ou talvez estejamos dizendo alguma coisa! Ou talvez não! De qualquer forma é... esperto". (...) Na tentativa de criticar a ânsia hipster pela próxima moda, Wasik pode ter criado A Próxima Moda. Se ele queria desferir um golpe contra a conformidade, ele pode ter dado à conformidade um veículo para parecer inconformada. ${ }^{216}$

215 JUNG, op. cit.

216 "Waterfight in Stanley Park, but are flash mobs starting to lose their edge?". Vancouver Sun, 12 de julho de 2008. Disponível em http://www.canada.com/vancouversun/news/ story.html?id=f4b1b51f-1340-46b3- 
Outros críticos, no entanto, aproximam os flash mobs dos happenings dos anos 60 ou mesmo os definem como uma subcategoria dos smart mobs ${ }^{217}$, uma forma emergente do ativismo político cujos protestos são organizados através de novas mídias como a internet e o telefone celular. Howard Rheingold, o proponente do termo, afirma que "smart mobs emergem quando a comunicação e a tecnologia informática amplificam os talentos humanos para cooperação. Os protestos anti-OMC em 1999 usaram websites atualizados dinamicamente, telefones celulares e outras táticas 'multiplicantes' na 'batalha de Seattle"' ${ }^{218}$. Surgido depois da formulação teórica de Rheingold, o projeto do flash mob de Wasik (e a grande maioria de seus desdobramentos futuros, desvinculados da experiência original em Nova York) não pretendia o mesmo vínculo ideológico. De fato, Wasik afirma que os flash mobs não são apropriados para portar mensagens.

Primeiro, (...) flash mobs são reuniões de iniciados, e por isso raramente comunicam com aqueles que não sejam. São piadas internas (...) que usam o mundo como terreno para um jogo privado. Em segundo, flash mobs são, por definição, transitórios, dez minutos ou menos, e portanto não apropriados como afirmação de postura ou testemunho. Em terceiro lugar, em termos de espaço físico, flash mobs estão baseados na construção da ilusão de uma força superior. (...) Apenas em espaços fechados a multidão pode gerar a necessária auto-admiração; permitir que a multidão se sinta pequena seria destruí-la. ${ }^{219}$

Não é possível desconsiderar os flash mobs quando se fala de uma ocupação lúdica e descolonizadora do espaço público nos últimos sete anos. Certamente eles compartilham elementos com os pranks, o que os fazem relevantes para esta pesquisa. No entanto é importante notar que, como a citação acima demonstra, parte dos flash mobs reivindica um franco afastamento do ativismo político. Isso é particularmente significativo se observarmos a facilidade com que a forma e a "atmosfera cool" dos flash mobs foram cooptados como estratégia de marketing de grandes corporações e como atrações televisivas voltadas ao público jovem.

8c14-97405c63b5fe - Acesso em 05 de janeiro de 2010.

217 Que pode ser traduzido por "multidão esperta".

218 Apud. JUNG, op. cit.

219 WASIK, op. cit. 
Para o lançamento de um de seus novos modelos de carro, a Ford preparou, em colaboração com a Sony, em julho de 2005, os "Fusion Flash Concerts", um evento anunciado à la flash mob, estrelando celebridades do hip hop e do rock. Em vez de simular a forma (o evento não durava menos do que dez minutos, não havia aglomeração e dispersão, não havia uma ação sem sentido a ser executada coletivamente), a Ford pretendeu se apropriar da espontaneidade dos flash mobs, buscando imprimi-la em sua marca.

Da mesma maneira, em 2006, a fabricante de relógios Swatch promoveu um concurso de flash mobs, vencido pelo grupo Newmindspace, que concorreu com uma briga de travesseiros coletiva em Nova York.

Em janeiro de 2009 a T-Mobile, empresa de telecomunicações, organizou um flash mob em Londres, no qual aproximadamente 350 bailarinos, misturados aos transeuntes, realizavam uma coreografia na estação de metrô de Liverpool Street ${ }^{220}$, que foi filmada para uma campanha publicitária cujo slogan era "Life is for sharing" (“A vida é para compartilhar"). Posteriormente, o "passo-a-passo" da coreografia foi postado no youtube, gerando versões amadoras do flash mob em outras localidades. Ainda envolvendo coreografias, em setembro de 2009, durante o programa de abertura da vigésima quarta temporada do Oprah's Show, gravado em um palco ao ar livre, montado em Chicago, uma multidão de 20 mil pessoas realizou uma dança sincronizada ao som de um hit da banda Black Eyed Peas, para espanto da apresentadora $^{221}$.

No Brasil, a assimilação do flash mob como produto de consumo também pode ser exemplificada pela produção do programa televisivo semanal Mob Brasil, apresentado no canal Multishow por Didi Wagner. A descrição da atração no site do canal é a seguinte: "Mobilização - este é o ponto de partida do programa. Em coautoria com um grupo de jovens, Didi vai levantar questões da vida urbana e criar

The T-Mobile Dance. Disponível em http://www.youtube.com/watch?v=VQ3d3KigPQM

221 Flash Mob - BEP - I Gotta Feeling. Disponível em http://www.youtube.com/watch?v=eyLuIY8IyO4 
uma intervenção para chamar a atenção ao assunto. (...) As ações são todas realizadas em São Paulo e inspiradas nos flash mobs que são sucesso no mundo inteiro" ${ }^{222}$.

A capacidade de corporações da indústria cultural de assimilar e cooptar os flash mobs de modo relativamente fácil lança um problema para a aplicação dos pranks como opção de performance para a rede de ativismo político contemporâneo. Há um espaço de disputa que não é apenas o espaço público pilhado pelo capital, mas o espaço da comunicação, da informação, das imagens e das ideias.

222 "Sobre o programa Mob Brasil". Disponível em http://multishow.globo.com/MOB-Brasil/Sobre-oPrograma/ Acesso em 15 de março de 2010. 


\subsection{A CULTURA BAGUNÇADA}

Liberdade de expressão é o direito de gritar "teatro" em um fogo lotado.

Provérbio Yippie

Uma câmera de vídeo caseira registra imagens de baixa qualidade na calada da noite. Dois jovens encapuzados e o cinegrafista pulam muros e cercas até chegarem perto de algo que parece ser uma base aérea. Militares são filmados ao longe, estão armados e têm cães de guarda. Eles vigiam o Air Force One, avião oficial da presidência dos Estados Unidos. Enquanto o cinegrafista se mantém distante, registrando as imagens, os jovens, mesmo ofegantes pela adrenalina, continuam sua missão. Vencem a última cerca que os separa do pátio da base aérea e, com um spray preto, escrevem "Still Free" ("Ainda livres") na turbina do avião presidencial. O vídeo $^{223}$, que dura aproximadamente dois minutos, ganhou notoriedade quase imediata na internet, recebendo, desde 2006, mais de 115 milhões de visualizações. O prank de comentário, incrivelmente arriscado e simbólico, ganhou a simpatia de inúmeros internautas discordantes dos rumos da política dos EUA da era Bush. Uma demonstração isolada, mas visualmente impactante, de que os poderosos no mundo não são capazes de seguir com seus desmandos sem que uma oposição a eles se levante.

Seria uma demonstração disto, certamente, se o homem que estivesse por trás deste prank não fosse Marc Milecofsky, um empresário que na década de 80 criou com grafite a identidade visual de sua marca de roupas, a Ecko. Hoje, a marca fatura mais de um bilhão de dólares anualmente, e seus negócios incluem revistas, patrocínio de eventos de skate, showbussiness, e franquias de videogames.

Marc não pichou o Air Force One. Ele criou um anúncio publicitário. O vídeo, produzido pela agência de publicidade Droga5, pretendia ser não só um suporte para a Ecko, mas "um momento de cultura pop" 224 . A agência alugou um avião e o pintou 
exatamente de acordo com o avião presidencial, atores interpretaram os militares e artistas de grafite (nenhum deles é Marc) simularam a invasão da base aérea. No início do filme, um dos supostos pichadores fala "Cara, isso não tá acontecendo", o que era a salvaguarda da Droga5 caso ela fosse acusada de violar o Ato Patriótico.

A peça publicitária apostou em uma alta dose da teatralidade, de uma elaborada maneira. O exemplo é complexo por dois motivos. Primeiramente, porque a "primeira camada" da audiência do vídeo já assiste a um prank (a pichação do avião presidencial), que retrata um exercício performativo (a noção de risco, o "dar-se a ver em ação", etc). À "segunda camada" da audiência é revelado que aquele primeiro prank de comentário era uma simulação. No fim, trata-se de um metaprank, um prank de comentário dentro de um prank de simulação. A eficácia deste último é dependente de que se acredite realmente que o avião presidencial foi alvo de uma pichação, para que então o jogo possa ser desmascarado e possa ser criada uma audiência de segundo nível, consciente do artifício da teatralidade.

Em segundo lugar, a complexidade está na cooptação do prank (aqui tratado claramente como recurso crítico e ativista - a pichação de "ainda livres" no avião presidencial é um manifesto de irreverência e posicionamento político) como veículo de marketing de uma grande corporação, a quem o prank adotado como opção performativa de ativismo estaria ideologicamente oposto. A publicidade, neste caso, se apropria de recursos que são utilizados para criticá-la.

O anúncio da Ecko não é, claramente, um exemplo isolado. Aproveitando uma crescente onda de marketing verde, isto é, que explora um nicho de consumidores comprometidos (pelo menos em discurso) com a sustentabilidade ambiental do planeta, a Volkswagen lançou, em 2009, uma campanha publicitária ${ }^{225}$ criada pela agência sueca DDB Stockholm. O título, bastante emblemático, é The Fun Theory ("a teoria da diversão") e parte da premissa de que a melhor maneira de envolver pessoas em mudanças positivas no ambiente é através da diversão. Para isso, elaborou vídeos registrando "experimentos", que nada mais eram do que pranks de situação. O 
primeiro deles foi a instalação de um mecanismo que transformava a escada da estação de metrô de Odenplan, em Estocolmo, em um teclado de um piano em grande escala. Cada degrau representava uma nota, cujo som era ativado pelos passos dos transeuntes ${ }^{226}$. O resultado do experimento foi um aumento de $66 \%$ do uso da escada normal em detrimento da escada rolante. O vídeo conclui: "A diversão pode obviamente mudar o comportamento para melhor. Nós chamamos isto de a teoria da diversão". O segundo vídeo da campanha ${ }^{227}$ propunha a pergunta "Será que mais pessoas jogariam seu lixo na lixeira se isto fosse divertido?" Em seguida mostrava a preparação de uma lixeira pública com um dispositivo que disparava um som como se ela fosse extremamente profunda (um som típico de grandes quedas em desenhos animados). Os transeuntes que a utilizaram ficavam admirados e curiosos. Procuravam algum lixo no entorno para acionar novamente a lixeira. "Em um dia, $72 \mathrm{~kg}$ de dejetos foram recolhidos em nossa lixeira. Isso é $41 \mathrm{~kg}$ a mais do que a lixeira mais próxima". Diferente da campanha da Ecko, a da Volkswagen previa uma ação dos transeuntes que acompanhavam seus experimentos, vale dizer, seus pranks engajavam os transeuntes em uma performance. Além desta participação, o site da campanha solicitava ao internauta, por meio de um concurso, o envio de outras ideias "divertidas" para mudar comportamentos ambientais. A ideia vencedora do concurso foi a de uma loteria que premia os motoristas que obedecem ao limite de velocidade.

Por meio da cooptação publicitária de pranks, tanto a Ecko quanto a Volkswagen capitalizaram uma atitude $\mathrm{cool}$, e alavancaram a venda de seus produtos. $\mathrm{Na}$ feroz competição do mundo das marcas, alcançar ou não o cool pode determinar o sucesso ou o fracasso comercial. De acordo com Naomi Klein, “cool, alternativo, jovem, moderno - como quer que se chame -, é a perfeita identidade que as empresas orientadas para produtos buscam para se tornar marcas transcendentes baseadas em imagem"228. A estratégia de apropriação do cool foi diferente em cada um dos casos. Enquanto a Volkswagen apostava em adicionar pitadas lúdicas às pequenas tarefas do

226 Piano stairs. Disponível em http://www.youtube.com/watch?v=21Xh2n0aPyw

227 The world's deepest bin. Disponível em http://www.youtube.com/watch? $=\mathrm{cbEKAwCoCKw}$

228 KLEIN, op. cit., 2002, p. 92. 
cotidiano, o cool capitalizado pela Ecko vinha da transgressão associada a uma arte gráfica de rua $^{229}$ que surgiu de maneira underground e que paulatinamente tem conquistado o mainstream.

Não só as marcas de roupas e a publicidade em geral incorporaram a transgressão representada pela arte gráfica de rua, mas também os espaços institucionais de "alta arte" também a veiculam. Desde a década de 1980 as galerias nova-iorquinas exibem artistas como Jean-Michel Basquiat, cujas origens estão nos muros da cidade. Mais recentemente, entre maio e agosto de 2008, a Tate Modern, importante espaço de exibição londrino, abrigou uma exposição intitulada Street Art, com a participação dos Gêmeos, dupla dos mais famosos grafiteiros do Brasil. A Bienal de São Paulo, que em 2008 alegou ter sido vandalizada por pichadores (o que culminou na detenção de Caroline Pivetta, uma das interventoras), abrirá as portas para a contribuição deles na edição de 2010 .

Seria falso, no entanto, afirmar que toda arte gráfica de rua adota o prank como prática, assim como também seria questionável associá-la imediatamente ao ativismo político contemporâneo. A intervenção sobre a placa de "PARE", apresentada como ponto de partida na introdução deste trabalho, serve como um exemplo germinador, onde expressão gráfica e irreverência, derrisão, provocação e jogo se articulam no prank. É possível, contudo, examinar de que forma prank, ativismo político, arte gráfica de rua e cooptação pelo mercado interagem a partir de um exemplo mais complexo.

A vietnamita Kim Phuc faz parte da história como protagonista de uma das imagens mais vistas do fotojornalismo mundial. No dia 8 de junho de 1972 sua aldeia foi bombardeada com napalm pelas tropas dos EUA. Kim, então com 9 anos, foi fotografada por Nic Ut correndo nua, aos prantos, após suas roupas e pele terem sido queimadas pelas explosões. A fotografia correu o mundo, tornou-se célebre e Ut

\footnotetext{
229 O termo "arte gráfica de rua" é, aqui, aproveitado como sinônimo do termo inglês street art, que designa expressões gráficas distintas e diversas, como grafite, pichação, stencil (grafite com o uso de uma moldura previamente desenhada), stickering (adesivos com imagens ou frases), etc. Ainda que não pretenda fazer aqui a discussão de sua origem, é fundamental reconhecer que boa parte desta arte urbana deve-se à popularização da cultura hip hop, a partir do final da década de 70.
} 
recebeu o prêmio Pulitzer de 1973. A imagem de Kim simboliza a face mais dolorosa e trágica do imperialismo dos EUA, materializado na Guerra do Vietnã. E se este símbolo desse as mãos aos símbolos sorridentes e festivos do imperialismo cultural?

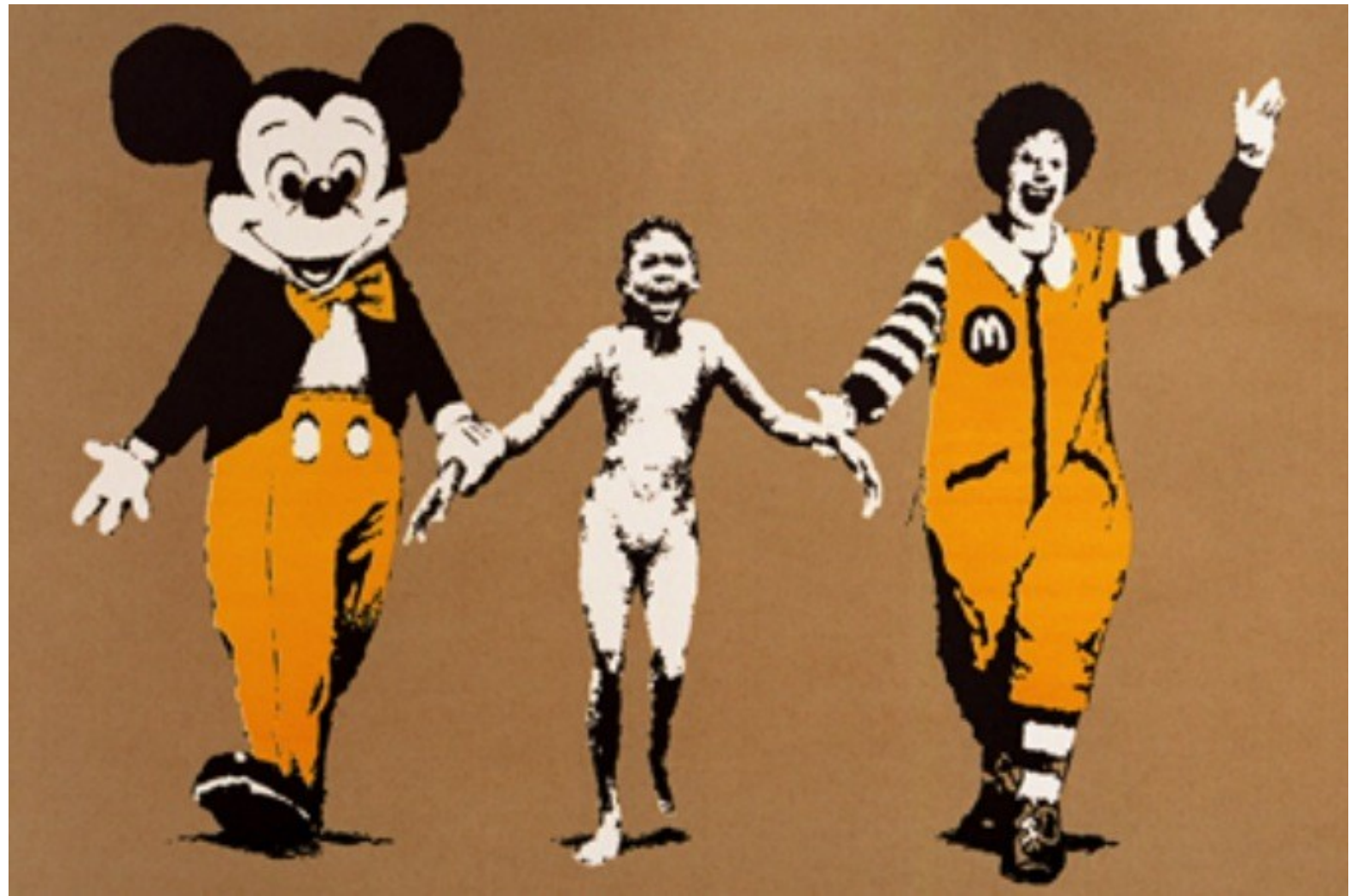

Figura 12: Stencil de Banksy a partir da foto do jornalista Nic Ut e de imagens de divulgação da Disney e do McDonalds.

Foi artista gráfico Banksy, nascido em Bristol, Reino Unido, que recontextualizou a imagem de Kim em um de seus stencils, colocando-a de mãos dadas com Ronald McDonald e Mickey Mouse. A maior parte da obra de Banksy é de pranks de comentário sobre o legado visual contemporâneo.

Banksy não concede entrevistas, não se deixa ser fotografado, prefere permanecer anônimo, enquanto sua obra encontra cada vez mais reconhecimento. Seus temas são predominantemente críticos à ordem estabelecida: “É preciso um bocado de coragem para se levantar em uma democracia ocidental e clamar por coisas em que ninguém mais acredita - como paz, justiça e liberdade" ${ }^{230}$. No bairro do Soho, em Londres, em 2005, ele desenhou dois policiais fardados se beijando; um outro policial foi retratado cheirando uma grande carreira de cocaína (ou melhor, um rastro de tinta

230 BANKSY. Wall and Piece. Londres: Century, 2005, p. 29. 
branca que passava por vários lugares do South Bankside, também em Londres); em 2002, a guarda especial da rainha foi desenhada portando tubos de spray e escrevendo o "A" anarquista e um "God Save the Queen", em Shoreditch e Notting Hill, respectivamente. Os policiais não foram as únicas figuras de autoridade satirizadas por Banksy. A Rainha Vitória, ícone da hegemonia do Império Britânico, foi retratada por ele sentada com as pernas abertas sobre o rosto de uma outra mulher, numa alusão explícita ao sexo oral. Outras séries de stencils de Banksy incluem desenhos de macacos e de ratos, colocados sempre de maneira provocadora. Um dos mais famosos é a de um macaco com um cartaz sobre o peito, no qual se lê "Ria agora, mas um dia estaremos no comando".

Além de usar o prank quando "comenta" uma imagem ou um personagem preexistente, Banksy proporcionou performances a partir de seus stencils. Um exemplo foi quando imprimiu em alguns muros uma cópia do brasão da prefeitura de Londres e colocou a seguinte inscrição abaixo: "Por ordem da Agência Nacional de Trânsito, este muro é uma área designada para grafite”. A sinalização parecia tão legítima que em quinze dias, dois do muros escolhidos já haviam sido totalmente tomados pelos sprays. A "designação" de áreas da cidade para determinado fim incluíram uma grande inscrição em Trafalgar Square, praça de Londres: "área designada para protestos”.

Imagine uma cidade em que o grafite não fosse ilegal, uma cidade em que todos pudessem desenhar o que quisessem. Em que cada rua estivesse inundada com milhões de cores e pequenas frases. Em que esperar pelo ônibus não fosse nunca entediante. Uma cidade que parecesse uma festa para qual todos tivessem sido convidados, não só os agentes imobiliários e os barões dos grandes negócios. Imagine uma cidade dessas e desencoste do muro - a tinta está fresca ${ }^{231}$.

A cidade e seus muros são os alvos preferenciais de Banksy. No entanto, seus pranks estendem-se até os museus da arte instituída. Exatamente por considerar que "quando se entra em uma galeria de arte você é um simples turista olhando para uma coleção de troféus de alguns milionários” ${ }^{232}$, Banksy decidiu executar pranks que ele chamava de "pinturas vandalizadas" em alguns dos principais museus do mundo. A 
performance consistia em preparar uma determinada pintura e pendurá-la clandestinamente na parede dos museus, sem nenhum prévio consentimento. Em 2003, ele comprou em uma feira de rua um quadro a óleo de uma pequena igreja em uma paisagem campestre e acrescentou à imagem faixas de segurança, usadas pela polícia para isolar uma cena de crime. Em seguida, pendurou o quadro em uma sala da Tate Galery, em Londres, onde permaneceu apenas duas horas e meia, devido à péssima qualidade da cola utilizada. Já no Louvre, em Paris, em 2004, a imagem escolhida para integrar o acervo foi de uma reprodução da Mona Lisa cujo rosto Banksy substituiu por um smile ${ }^{233}$. O New York Metropolitan Museum, o Natural History Museum, o Brooklyn Museum e o Museum of Modern Art, todos em Nova York, também receberam "pinturas vandalizadas", sendo que no último a imagem era uma paródia de Andy Warhol. Em vez da famosa sopa Campbell, Banksy pintou a embalagem de uma sopa de tomate do Tesco, supermercado conhecido por seus produtos populares.

O mais célebre destes pranks, no entanto, é um fragmento de rocha sobre o qual Banksy simulou uma pintura rupestre. A imagem, que mostra um bisão ferido por setas e um ser humano pilotando um carrinho de supermercado, foi colocada clandestinamente em uma parede do British Museum, em Londres, onde permaneceu sem ser percebida por oito dias. Depois ela foi retirada, mas hoje, aproveitando a galopante fama do artista, integra a coleção permanente do museu.

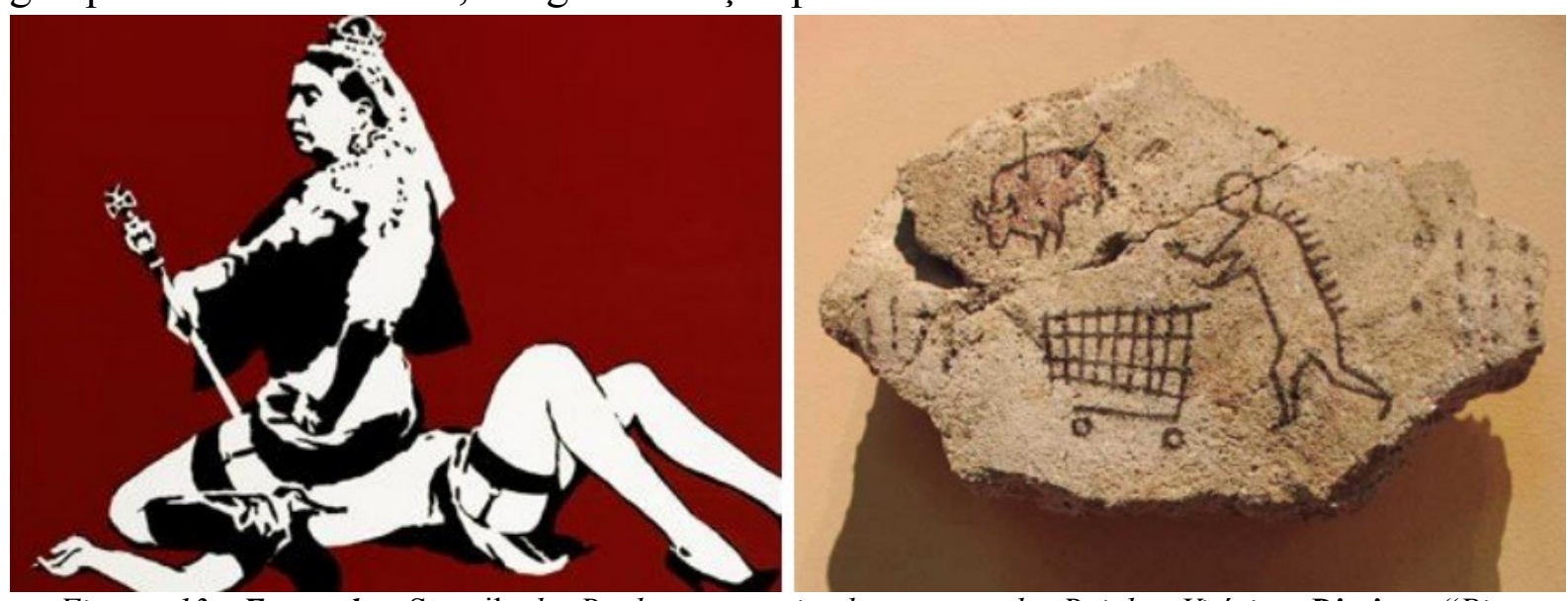

Figura 13: Esquerda: Stencil de Banksy a partir do retrato da Rainha Vitória. Direita: "Pintura vandalizada" de Banksy, uma arte rupestre da era consumista, exposta no British Museum, Londres, Reino Unido.

233 Imagem esquemática de dois olhos e uma boca sorrindo sobre um círculo amarelo. 
De fato, a atitude irreverente e mal-comportada de Banksy rendeu-lhe uma visibilidade que prontamente foi incorporada pelo mercado. Seus catálogos são bestsellers nas livrarias, há mapas para visitação de seus stencils na cidade e diversas lojas de souvenires oferecem camisetas, bottons e gravuras de imagens suas. A opção pelo anonimato colabora para criar em torno dele um mito, o que valoriza ainda mais as suas obras. Celebridades como Christina Aguilera, Jude Law, Keanu Reeves, Denis Hopper, Angelina Jolie e Brad Pitt já adquiriram obras de Banksy em leilões, com preços que chegaram a 280 mil libras. A mais curiosa das vendas de Banksy foi a de um grafite que ele pintou em um muro de Bristol (uma de suas últimas obras antes de adotar a técnica do stencil): literalmente, por 102 mil libras, foi vendido um grafite em um muro, com uma casa em anexo.

"Banksy é o próximo Andy Warhol", escreveu um colunista da revista Esquire $^{234}$, publicação que em 2005 elegeu Banksy como uma das "melhores e mais brilhantes" personalidades do ano. A relação dele em relação à mercantilização de sua obra, em relação à sua transformação em celebridade e em relação à sede das marcas corporativas por capitalizar sua atitude cool é bastante ambivalente ${ }^{235}$. Em fevereiro de 2007, no mesmo dia em que a casa de leilões Sotheby's vendia três de suas obras por preços que superavam em várias vezes o valor estimado de arremate, Banksy postou em seu site ${ }^{236}$ um novo trabalho, retratando um leilão em que os participantes davam lances para comprar um quadro em que estava escrito "Eu não acredito que estes idiotas estão comprando esta merda". Com a mesma virulência demonstrada em relação ao mercado de arte, Banksy pratica o que chama de "brandalismo", que é a vandalização em seus trabalhos de corporações como McDonalds, Burger King, Tesco, Disney, etc. "Qualquer anúncio em um espaço público que não te dê a chance de vê-lo

234 BUZZELL, Colby. "I am Banksy". Revista Esquire, 30/11/05. Disponível em http://www.esquire.com/ features/best-n-brightest-2005/ESQ1205BANKSY 198?click= main_sr - Acesso em 05 de fevereiro de 2010.

235 Simon Hattenstone, a quem Banksy concedeu uma raríssima entrevista, considera que "assim como Naomi Klein, ele se opõe às marcas corporativas e se tornou uma marca no processo". HATTENSTONE, Simon. "Something to spray". The Guardian, 17/07/03. Disponível em http://www.guardian.co.uk/ artanddesign/2003/jul/17/ art.artsfeatures - Acesso em 12 de abril de 2010.

236 www.banksy.co.uk 
ou não é seu. Pertence a você. Você pode pegá-lo, rearranjá-lo e reutilizá-lo. Pedir permissão é como pedir para guardar uma pedra que alguém acabou de jogar na sua cabeça" ${ }^{237}$. Mesmo sendo cruel e ridicularizador sobre a imagem de poderosas empresas multinacionais (ou justamente por isso), ele é constantemente solicitado a criar campanhas publicitárias de marcas como a Nike, convites que ele recusa prontamente. "A lista de trabalhos que eu não fiz é muito maior do que a lista de trabalhos que eu fiz. É uma espécie de currículo invertido" ${ }^{238}$.

A estratégia adotada por Banksy de subverter fragmentos visuais (sejam eles de fotojornalismo, de logotipo de marcas, de personalidades, etc) para criar um prank de comentário já era prática corrente para os situacionistas. Ao lado da deriva, eles propunham, como metodologia de construção de situações, o détournement, estratégia que consistia em remodelar e recontextualizar imagens e sons preexistentes. A tradução para détournement pode ser "desvio", mas também "afastamento", "sequestro", "rapto". $\mathrm{Na}$ definição situacionista, trata-se da manipulação e reconfiguração de elementos estéticos pré-fabricados, sejam eles produções artísticas, jornalísticas ou de entretenimento, atuais ou passados, para uma construção superior do ambiente. Anselm Jappe afirma que "trata-se de uma citação, ou de uma reutilização num sentido mais geral, que 'adapta' o original a um novo contexto" ${ }^{239}$. Essa reinvenção dos elementos da cultura passada era inspirada pelo poeta francouruguaio Lautréamont, que concebia o détournement como o ato de tomar coisas do inimigo para montar uma outra coisa, que ajudasse a combater o mesmo inimigo. $\mathrm{O}$ parágrafo 207 da Sociedade do Espetáculo, de Guy Debord, é um desvio de Lautréamont: “As ideias melhoram. (...) O plágio é necessário. O progresso supõe o plágio. Ele se achega à frase de um autor, serve-se de suas expressões, apaga uma ideia errônea, a substitui pela ideia correta" ${ }^{240}$. O desvio é uma atitude crítica sobre o passado, na medida em que é uma inversão das relações estabelecidas entre conceitos e

BANKSY, op. cit., p. 196.

HATTENSTONE, op. cit.

JAPPE, op. cit., 1999, p. 84.

DEBORD, op. cit., parág. 207. 
uma subversão das conclusões cristalizadas em verdades. Como técnica, o détournement aparenta-se à colagem dadaísta. No entanto, ele estabelece uma relação dialética de desvalorização e revalorização com o material editado. Um exemplo bastante utilizado de détournement situacionista era tomar histórias em quadrinhos estadunidenses e substituir os balões com as falas dos personagens por textos revolucionários.

Uma utilização mais recente do conceito de détournement aconteceu quando, em 1984, a banda de audiocolagem Negativland cunhou o termo culture jamming ${ }^{241}$ para descrever as alterações em outdoors e outras formas de sabotagem de mídia (circulação de notícias falsas, paródias de logotipos, etc). "Parte terroristas artísticos, parte críticos vernaculares, os culture jammers (...) introduzem o ruído enquanto o sinal passa do transmissor ao receptor, encorajando interpretações idiossincráticas e não intencionais. Invadindo os invasores, eles investem com motivações subversivas sobre anúncios, noticiários e outros artefatos da mídia; simultaneamente eles os decifram, deixando sua sedução impotente" ${ }^{242}$. Na prática, os culture jammers alteram drasticamente as mensagens veiculadas pela mídia corporativa, sabotando-a em seu método de comunicação e criando uma interrupção na experiência normativa de consumo. André Mesquita afirma que o poder do culture jamming "está no improviso, em acessar ilegalmente o interior dos códigos corporativos de comunicação para raptar suas imagens, slogans e logomarcas. (...) [É] uma prática aberta de ativismo semiótico, uma ferramenta para ações de resistência simbólica, instruída por estratégias

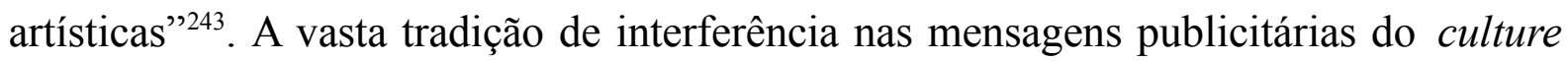

241 "O termo jamming é uma gíria da língua inglesa associada com a prática de interferir em transmissões de rádio com ruídos ou sobreposição de transmissões. Vem do verbo 'to jam', que é utilizado com diversos significados, como entupir, perturbar e confundir. Uma tradução aproximada de culture jamming seria, portanto, 'causar confusão na cultura"'. (ASSIS, Érico. Bagunçando a cultura: interferência e criatividade como tática de protesto. Artigo apresentado ao Programa de Pós-Graduação em Ciências de Comunicação da UNISINOS, São Leopoldo, 2004). Érico Assis propõe uma interessante tradução de culture jamming, que é "bagunça criativa", termo a que faço referência no título deste subcapítulo.

242 DERY, Mark. Culture jamming: hacking, slashing and sniping in the empire of signs. Disponível em http://www.markdery.com/archives/books/culture jamming/ - Acesso em 12 de abril de 2010.

243 MESQUITA, op. cit., p. 197. 
jamming acomoda um grande número de práticas, algumas das quais optam pela verve divertida e irônica do prank.

O Billboard Liberation Front ("Frente de Liberação dos Outdoors" - BLF), por exemplo, leva a cabo seus pranks de comentário sustentando a eficiência da opção vinculada ao lúdico e ao cômico. "No princípio, era o Anúncio", afirma o manifesto do grupo, "Anunciar é existir e existir é anunciar" ${ }^{244}$. Atuando principalmente na Califórnia, desde 1977, o BLF cria pranks que se concentram em "melhorar" anúncios da AT\&T, da Forbes Magazine, da Apple, da Levi's, da Camel ou de diversas outras marcas que estampam seus logotipos em outdoors. Jack Napier ${ }^{245}$, porta-voz do grupo, considera que "publicidade é uma linguagem. Falam com você constantemente por meio desses anúncios. Mas você pode responder a eles! Você pode transformar [esta comunicação] em diálogo" ${ }^{246}$.

No aniversário de 50 anos do McDonalds, em 2005, o "diálogo" que o BLF estabeleceu com o aniversariante foi o de criar um outdoor especial para o evento. Um Ronald McDonald gordinho de um lado do anúncio, o típico "M" amarelo, grande, no centro, e um alienígena no outro lado, com o breve slogan "To serve man" ("Servir homens") escrito sobre o "M". Além da mensagem algo lacônica, o BLF acrescentou na frente do anúncio um mecanismo composto por dois manequins animados eletronicamente - um Ronald McDonald em tamanho natural que levava um sanduíche até a boca de um garotinho obeso. A peça publicitária foi acompanhada de um release de imprensa, que revelava a tarefa secreta da empresa de fast-food: engordar a humanidade para servi-la como comida para alienígenas. Algumas horas após a colocação do anúncio, um comerciante resolveu chamar a polícia, que foi obrigada a apreender os bonecos. Ronald McDonald foi levado de camburão, em uma clara demonstração de como um prank de comentário sobre a publicidade configura-se como performance crítica, como contramensagem irreverente.

\footnotetext{
244 http://www.billboardliberation.com/manifesto.html - Acesso em 10 de abril de 2010.

245 O pseudônimo foi emprestado do arqui-inimigo do Batman, Coringa, cujo nome real na história em quadrinhos era Jack Napier.

246 Jack Napier, em entrevista concedida a V. Vale, Marian Wallace e Mal Sharpe in Pranks \#2, op. cit., p. 93.
} 

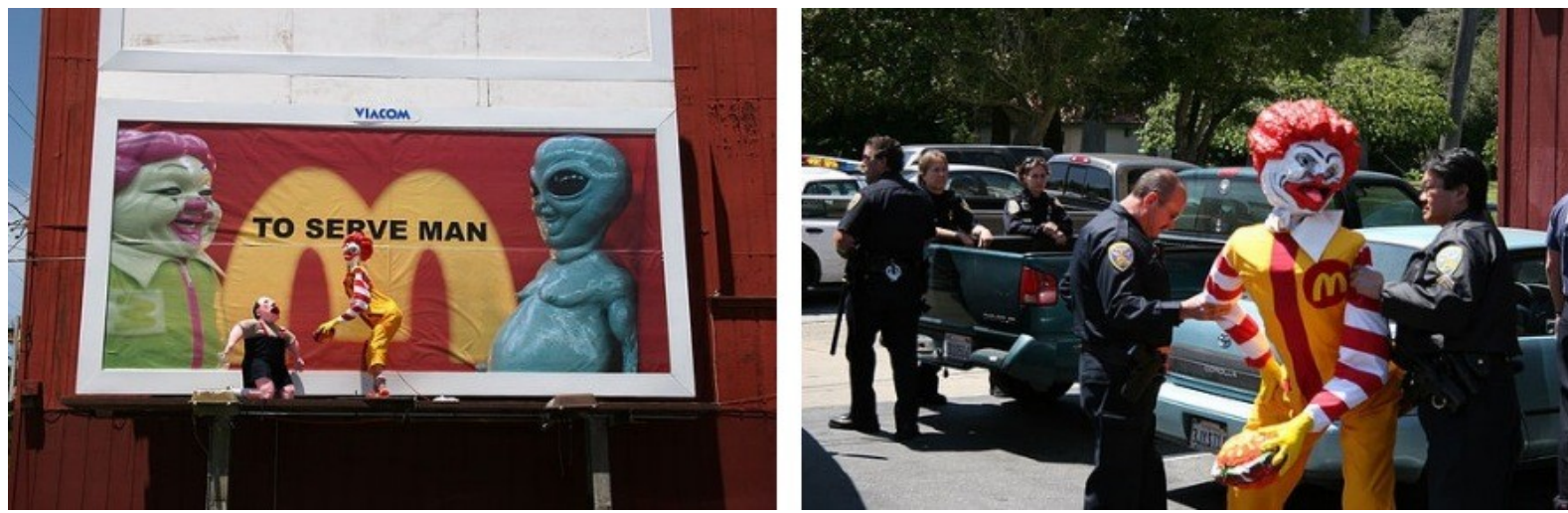

Figura 14: Esquerda: Anúncio anti-McDonalds da Billboard Liberation Front, 30 de maio de 2005, San Francisco, EUA. Direita: Ronald McDonald sendo preso por policiais.

Os melhores pranks são bem elaborados e bem humorados. Você pode pichar "foda-se McDonalds" em um outdoor e quem já é antiglobalização vai balançar a cabeça e concordar. Mas isto é pregar para os convertidos. São as pessoas que não necessariamente pensam desta forma que eu quero atingir. Gosto quando as pessoas param e olham, especialmente se for algo confuso. Vai haver um segundo em que elas vão pensar “que porra é essa?”... um pequeno curto-circuito que faz as pessoas pensarem sobre onde elas estão e questionar o que é a publicidade na verdade ${ }^{247}$.

O subvertising (subversão do advertising, da publicidade) também é o foco da ação da Adbusters ${ }^{248}$, organização baseada em Vancouver, no Canadá que, desde 1989, busca utilizar instrumentos publicitários para criticar o consumismo. Uma de suas estratégias, aparentada à estratégia da BLF, é a paródia de anúncios de grandes corporações. No entanto, em vez de utilizar a técnica do palimpsesto $^{249}$, a Adbusters cria novas peças publicitárias (criadas por uma agência de publicidade própria, a Powershift), utilizando-as como prank de comentário inseridos em outdoors, televisão, mídia impressa e internet. As indústrias do tabaco, do álcool, de fast food e de moda são os alvos preferenciais. Uma paródia do anúncio da vodka Absolut, por exemplo, mostra o contorno de uma grande garrafa desenhada com giz no asfalto, como se ali tivesse sido encontrada uma vítima de assassinato recente. A legenda diz “aproximadamente 50\% das mortes no trânsito são ligadas ao álcool. 10\% dos norteamericanos são alcoólatras. Um adolescente vê 100 mil anúncios de bebidas antes de atingir a idade legal para beber". Em um outro anúncio, paródia da Nike, vemos uma jovem oriental correndo descalça. O texto diz "Você está correndo para conseguir

247 Ibid., p. 93.

248 https://www.adbusters.org/ O nome da associação pode ser traduzido como "detonadores de anúncios".

249 A maioria dos outdoors "melhorados" pela BLF são inscrições sobre um anúncio preexistente no local, alterando palavras ou imagens. Neste aspecto, o anúncio do McDonalds é uma exceção 
aquele aumento, e ser tudo o que quer ser. Mas não é fácil quando se trabalha sessenta horas por semana fazendo tênis em uma fábrica da Indonésia e todos os seus amigos desaparecem quando pedem por um aumento. Então pense globalmente antes de decidir que é tão cool calçá-los".
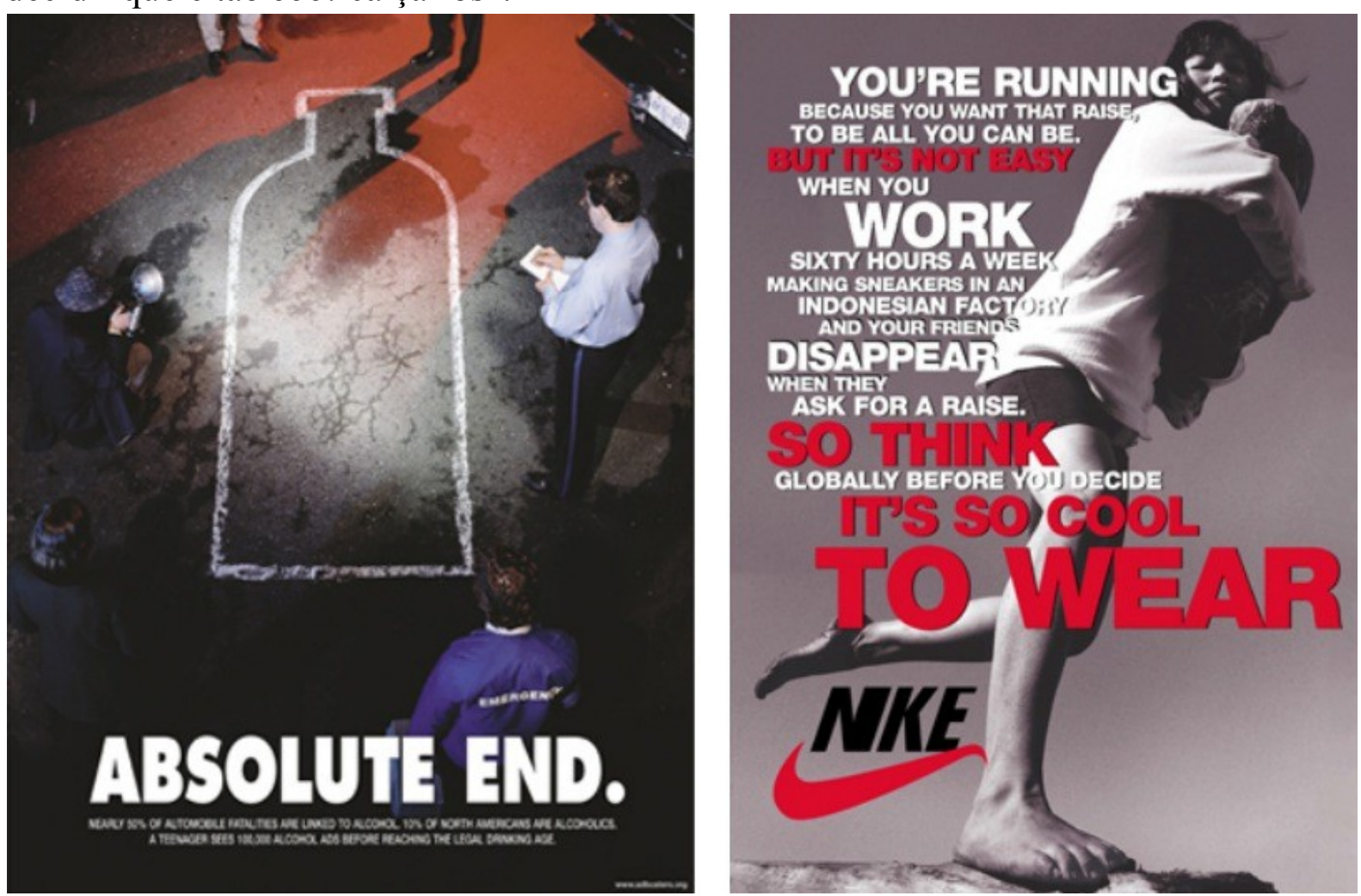

Figura 15: Esquerda: Anúncio paródia da Absolut Vodka. Direita: Anúncio paródia da Nike.

A Adbusters publica uma revista bimestral de mesmo nome, com tiragem de 120 mil exemplares, sendo uma edição canadense, uma estadunidense e uma internacional. A revista veicula matérias, informações anticonsumistas e divulga as demais campanhas da rede Adbusters, como o "Buy Nothing Day" ("dia de comprar nada", que desde 1997 é agendado para a sexta-feira posterior ao dia de ação de graças, tradicional dia de compras natalinas e um dos 10 dias de maior faturamento nas lojas dos EUA) e a "TV Turnoff Week" ("semana da tv desligada" ${ }^{250}$, que acontece na semana em que as emissoras televisivas dos EUA avaliam seus números de audiência para estimar o valor de seus intervalos comerciais).

250 Desde 2008 teve seu nome alterado para "Digital Detox Week" ("semana da desintoxicação digital”), para incluir o desligamento de computadores e outros meios de aparelhos digitais produtores de imagem. 
Outro viés de atuação da Adbusters foi o lançamento de uma marca, a Blackspot, cuja meta era participar do mercado de maneira ética. A Blackspot fabrica tênis usando fibra de cânhamo, pneus reciclados e couro vegan. A linha de produção é em fábricas sindicalizadas em Portugal e os tênis são distribuídos de maneira independente para pequenos comerciantes que circulam o dinheiro localmente. A marca Blackspot é open-source, ou seja, pode ser usada por qualquer pessoa sem custos adicionais. A logomarca é um círculo preto desenhado a mão, que a Adbusters estimula que seja desenhada também sobre as logomarcas dos tênis feitos por outras empresas. "Blackspot é mais do que promover uma marca ou desconstruir o significado de cool - é mudar a maneira com que o mundo faz negócios" ${ }^{251}$.

Uma crítica parecida com a que pesa sobre Banksy pode ser feita à Adbusters, a de que ela "se transformou em uma organização gerenciadora de um novo estilo de vida para uma 'rebelião cultural', algo que nem de longe representa uma ameaça ao sistema, mas o próprio sistema." 252 . Isso porque "a ortodoxia capitalista com sua sede pelo autêntico e o diferente pode facilmente cooptar com sucesso o conteúdo político de uma manifestação para vendê-la como imagem. (...) Protestar virou uma atitude cool, um novo ativismo patrocinado pela marca. A rebelião existencial é o estilo oficial do capitalismo flexível" 253 . Esta capacidade de incorporar como valor aquilo que em tese seria seu antípoda é precisamente o que está materializado na campanha publicitária da Ecko, Still Free.

Em face desta disputa no campo ideológico, os ativistas vêm procurando caminhos que sejam muito difíceis de serem recuperados pelo capital. Uma destas tentativas é o lançamento da grife Yomango. "Yomango é uma marca que, como todas as outras marcas, não vende nada, salvo um estilo de vida. O estilo de vida de yomango é muito fácil de adivinhar: é roubar" ${ }^{254}$, declarou Leónidas Martín, um dos idealizadores da grife. O nome vem, de um lado, de uma paródia com a marca de

\footnotetext{
251 https://www.adbusters.org/campaigns/blackspot

252 MESQUITA, op. cit., p. 199.

253 Ibid., p. 213.

254 Leónidas Martin em entrevista ao documentário que ele próprio dirige. ARTIGAS, e MARTIN, op. cit.
} 
roupas espanhola Mango. Mas, sobretudo, está ligado à gíria “mangar”, que é algo como "afanar" em português.

O estilo Yomango propõe "reapropriar-se", legitimar e estender a "expropriação" daquilo que, antes de sua conversão em "coisa", pertencia ao comum. Yomango põe ao alcance da sua mão o que é seu, e tudo está ao alcance de sua mão. (...) Yomango é também a produção de ferramentas (roupas, acessórios, instrumentos) e o reforço de gestos cotidianos (comportamentos, ações) para viver Yomango. Não é uma questão de segredos nem de tecnologias complexas, mas de viabilizar uma sabotagem cotidiana e prazerosa contra o capital. (...) Yomango não é o fomento da propriedade privada por outros meios. Não propõe a acumulação de caçarolas ou queijos camembert. Consiste em levar ao extremo a livre circulação de bens. (...) Reapropie e faça circular. Satisfaça seus desejos e a necessidade de seus semelhantes. Yomango é uma franquia que pode ser montada em qualquer lugar. O estilo Yomango é um processo aberto. Cria ferramentas, protótipos, e dinâmicas que fluem e proliferam, que esperam ser reapropriadas e circular. Uma marca que é de todo mundo. Que vai e vem do comum. $^{255}$

Yomango não é meramente o elogio ao roubo, mas a utilização subversiva, performativa e anticonsumista do ato de roubar e redistribuir. Na página inicial de um de seus sites, afirmam "Yomango não é roubo. A propriedade é o roubo" ${ }^{256}$. Na página inicial do outro, jocosamente exibem uma foto de Winona Ryder (atriz conhecida por sua cleptomania), com uma tatuagem escrita Yomango ${ }^{257}$. Além de mercadorias, Yomango também se apropria de slogans de outras marcas. Assim, a clássica frase associada à Mastercard transformou-se em "há coisas que o dinheiro não pode comprar. Para todas as outras, Yomango". Outros slogans são: "Yomango, porque a felicidade não se pode comprar" e "Yomango. Você quer? É seu"

A primeira performance-prank da marca aconteceu em 5 de julho de 2002, quando um grupo de aproximadamente cem pessoas armou uma espécie de passarela na calçada diante da loja Bershka, em Barcelona. O desfile que se deu então foi para o lançamento da marca Yomango. Com a confusão que se instaurou pela presença dos ativistas, os funcionários da loja não perceberam o furto de um vestido azul, que foi a

\footnotetext{
255 “10 claves para un estilo de vida Yomango". Disponível em http://www.sindominio.net/fiambrera/007/ ymng/claves.htm. Acesso em 30 de abril de 2010.

256 http://www.yomango.net

257 http://www.yomango.org
} 
principal peça do desfile, e que, em seguida, ficou em exposição no Centro de Cultura Contemporânea de Barcelona ${ }^{258}$.

Em 20 de dezembro de 2002 um grupo Yomango realizou um prank de situação em homenagem ao aniversário da revolta popular argentina que, ao som de panelaços e gritos de "Que se vayan todos" ("Que saiam todos"), retirou do poder quatro presidentes em menos de três semanas. A performance criada para ocasião foi Yomango Tango ${ }^{259}$ e também aconteceu na cidade de Barcelona. Sete casais entraram em uma loja da rede de supermercados Champion, franquia do gigante do setor, Carrefour. Vestidos a caráter, todos dançaram um emocionado tango, ao som de bandoneóns. Entre um passo de dança e outro, aproveitavam para esconder em bolsos especialmente confeccionados para a ocasião garrafas de vinho e de champagne. Os funcionários do estabelecimento, admirados e constrangidos, não evitaram a ação dos dançarinos ladrões. Uma porta-voz dos manguistas anunciava em um microfone: "contra o capitalismo, criatividade e 'manguismo"'. O resultado do butim foi reunido em uma cesta de natal. No dia seguinte, os dançarinos de tango se reuniram no interior de uma agência do banco Santander (considerado um dos muitos bancos que levaram a Argentina à crise), para fazer um brinde e celebrar o aniversário da revolta com as bebidas "mangadas" na noite anterior.

Seja na interferência sobre imagens canônicas ou mensagens publicitárias, seja na criação de marcas anticonsumistas, há um interesse de indivíduos e grupos ativistas em pranks cujas performances extrapolem a descolonização e a reivindicação do espaço urbano. Hakim Bey afirma que "a contracultura e os protestos começaram a buscar a 'exposição da mídia' porque eles sabiam que suas imagens estavam mais atrativas que a ideologia que guardava as imagens" ${ }^{260}$. Para acessar esta esfera intangível da comunicação e da informação os ativistas se esforçam em dominar e manipular as ferramentas da mídia. É o que Brian Holmes chama de “imagenharia

258 YOMANGO. Presentación oficial de la marca en sociedad. Disponível em http://www.youtube.com/watch? $\mathrm{v}=\mathrm{wED} 5 \mathrm{Zn} 0 \mathrm{k} 8 \mathrm{fE}$

259 Yomango-Tango. Disponível em http://www.youtube.com/watch?v=rXBSAubWc1A

260 BEY, op. cit., 2001, p. 33. 
reversa", ou seja, identificar processos da engenharia de imagens de determinada esfera detentora do poder para desfazer estes mesmos processos ${ }^{261}$. Os pranks que atuam na camada fluida da cultura visam exatamente a este objetivo político.

Outras táticas de pranks ativistas que buscam inviabilizar a recuperação de suas performances pelo capital incluem a já clássica "torta na cara" de personalidades alvo de suas reivindicações políticas. $\mathrm{O}$ uso ativista das tortadas começou nos anos 60 , nos EUA com os Yippies ${ }^{262}$, e na Europa com o anarquista belga Noël Goldin. Ao longo das últimas décadas, vários indivíduos e grupos que utilizam as tortadas como prank de situação ganharam visibilidade. Dentre eles estão Les Entartistes (algo como "Os entortadores"), do Canadá; os estadunidenses Biotic Baking Brigade ("Brigada de confeitaria biótica") e os transnacionais Bakers Without Borders ("Confeiteiros sem fronteiras"). "As tortas são uma forma de 'esperanto visual', (...) Uma tortada é um ataque direto ao corpo da autoridade. Aqueles que são alvos destes pranksters experimentam humilhação pública, mas a ferida é em seu orgulho, não em sua anatomia. (...) As tortas provam que ninguém é intocável” ${ }^{263}$. A lista de alvos é imensa, inclui Bill Gates, Milton Freidman, Sylvester Stallone, Ronald McDonald, Timothy Leary, Andy Warhol, o prefeito de San Francisco, Willie Brown; o premiê canadense, Jean Chretien; o rei sueco, Carl Gustaf; e o diretor da Organização Mundial do Comércio, Renato Ruggiero. A pesquisadora Audrey Watters reclama de que a imprensa muitas vezes está mais interessada no sabor da torta do que no motivo da tortada. "Utilizando tortas, os ativistas políticos são capazes de minar hierarquias, caçoar de autoridades e capturar a atenção da mídia e do público em geral. A imagem da torta na cara é um ato popular de ridicularização e um símbolo bem conhecido de irreverência" ${ }^{264}$, forte o suficiente para que nenhuma ação de assessoria de imprensa

\footnotetext{
261 cf. HOLMES, op. cit.

262 Os Yippies são os membros ou os simpatizantes do Youth International Party ("Partido Internacional da Juventude" - YIP) nos EUA. O "partido" (sem filiação ou hierarquia) era envolvido com os movimentos contraculturais de liberdade de expressão e contra a guerra nos anos 60. Em 1968 lançaram um porco como candidato a presidente da república. Uma figura emblemática do YIP foi o ativista Abbie Hoffman

263 WATTERS, op cit.

264 Ibid.
} 
consiga minimizar. Este prank de situação se mantém como uma performance subversiva e cômica.

No dia 27 de outubro de 2000, em Salzburgo, um ativista não identificado atingiu com uma torta o Dr. Andreas Bichlbauer, que estava na Áustria representando a Organização Mundial do Comércio em uma conferência sobre serviços internacionais. Inconformado com o teor neoliberal do discurso do porta-voz da OMC, um ativista aproximou-se dele e acertou-o em cheio com uma tortada. A torta, no entanto, continha algum tipo de bactéria que causou uma severa infecção em Bichlbauer. Ele permaneceu internado em Viena até 26 de novembro, quando faleceu em decorrência da infecção. Foi o primeiro óbito relacionado a tortadas na cara.

O falecido Dr. Bichlbauer e o porta-voz da Dow Chemical, Jude Finisterra, que conhecemos no segundo capítulo, são a mesma pessoa. Ambos são impostores, personagens dos pranks de simulação do grupo Yes Men. O projeto que estes ativistas desenvolvem consiste em atuar como falsos porta-vozes e apresentar teorias e políticas oficiais dos órgãos e empresas que são seus alvos, mas de uma maneira muito mais sincera, fazendo-as parecer como os absurdos que elas são de fato. O que os Yes Men evidenciam são os traços de identidade que as instituições prefeririam que permanecessem escondidos. Por isso que eles chamam seus pranks de "correção de identidade": "enquanto o ladrão de identidades as rouba para engajá-las em práticas criminais, os Yes Men visam identidades que sejam criminosas para apresentá-las de modo honesto", afirma Mike Bonanno ${ }^{265}$, um dos membros do grupo.

Antes de formar o Yes Men com Andy Bichlbaum, Bonanno já realizava pranks que trabalhavam na interface entre performance e ativismo. Em 1993, ele organizou a Barbie Liberation Organization ("Organização de Libertação da Barbie" - BLO), que comprou cerca de 300 bonecas Barbie e bonecos GI Joes ${ }^{266}$ e trocou suas caixas de vozes. As Barbies passaram a dizer "mortos não mentem" ou "a vingança será minha", enquanto os GI Joes exclamavam "matemática é difícil", "eu adoro fazer compras" ou

\footnotetext{
265 No filme de OLLMAN, Dan; PRICE, Sarah e SMITH, Chris. The Yes Men, 2003.

266 GI Joes são uma linha de bonecos que reproduzem soldados da força militar dos EUA.
} 
“será que um dia vamos ter roupas o suficiente?”. Então, a BLO realizou uma “compra reversa", isto é, devolveu os bonecos comprados para as prateleiras das lojas, às vésperas do natal. Sobre a generosidade da BLO com as lojas, que puderam vender o mesmo produto duas vezes, Bonanno afirmou "nós somos como o Papai Noel, só que menos radicais, porque o Papai Noel invade a casa das pessoas, e nós não fazemos isso" $" 267$. A grande mídia foi atraída para a causa da Barbie Liberation Organization, que se define como "uma organização de ativismo cultural que desafia os estereótipos de gênero da indústria de brinquedos por meio de táticas de intervenção e cirurgia de troca de gênero vocal" ${ }^{268}$. No prank de armadilha perpetrado pela BLO já havia a semente do mote de "correção de identidade" dos Yes Men.

O primeiro alvo a ter sua identidade corrigida foi o então candidato à presidência da república dos EUA, George W. Bush. Os Yes Men criaram o site gwbush.com, que era uma paródia do site oficial do candidato, georgewbush.com. No site pirata, os Yes Men puderam desmentir afirmações absurdas do político, como a de que ele teria transformado o Texas no estado mais ecológico do país. Quando perguntaram para Bush em uma coletiva de imprensa o que ele pensava a respeito do site falso, ele afirmou que "deveria haver limites para a liberdade", uma infeliz frase que foi reproduzida em centenas de jornais e canais de televisão, e que demonstrou a linha mestra da administração de Bush como presidente.

Após o sucesso da experiência com Bush, os Yes Men visaram a um alvo mais expressivo, a Organização Mundial do Comércio:

Eles não foram eleitos por ninguém. Eles não prestam contas a nenhum eleitorado. Quando eles remodelam a economia mundial de forma que a maioria da população mundial se opõe, a única justificativa é que eles sabem o que é melhor para o mundo. E se eles não souberem? E se eles forem apenas um punhado de homens ordinários, com uns ternos bonitos, um escritório chique na Suíça e algumas crenças arraigadas tão arbitrárias quanto as da inquisição espanhola? Neste caso, eles são apenas os testas de ferro do poder tomado por impiedosas corporações. ${ }^{269}$

267 Ibid.

268 "Barbie Liberation Organization”. Disponível em http://www.vdb.org/smackn.acgi\$artistdetail? BARBIELIBE Acesso em 21 de abril de 2010.

269 THE YES MEN. The Yes Men: the true story of the end of the World Trade Organization. Nova York: Disinformation, 2004. p. 9. 
A estratégia inicial foi parecida com a usada contra Bush. O site gatt.org, administrado pelos Yes Men, simulava o site oficial da $\mathrm{OMC}^{270}$, mas as paródias neste caso eram mais sutis do que no caso do gwbush.com, o que fazia com que alguns internautas descuidados o confundissem com o site oficial e mandassem e-mails solicitando informações, declarações e, eventualmente, convidassem porta-vozes da organização para proferir palestras em encontros e congressos. Além do prank da paródia em si, os Yes Men enxergaram a possibilidade de corrigirem a identidade da OMC apresentando sua verdadeira face, sem vergonha. Foi quando nasceu o Dr. Bichlbauer.

Em Salzburg, antes de ser atingido pela torta mortífera, Bichlbauer proferiu uma fala propositadamente polêmica. Expressando a preocupação da $\mathrm{OMC}$ com as barreiras que atrapalhavam a prosperidade do livre comércio, ele criticou duramente as tradicionais siestas na Espanha e na Itália, considerando que elas reduzem a produtividade dos trabalhadores daqueles países. Também tratou de barreiras sistêmicas para o livre comércio, como alguns preceitos da democracia, especialmente as eleições diretas, que excluem das "mãos invisíveis do mercado" as decisões sobre a vida política. Como solução a este problema específico, ele apresentou o voteauction.com, um sistema em que o eleitor que desejar pode leiloar o seu voto, para o político ou a empresa que apresentar a melhor oferta de compra.

O prank de simulação na Áustria foi o primeiro de uma série de performances que os Yes Men executaram em nome da OMC. Apesar de dependerem exclusivamente da teatralidade para o sucesso de suas empreitadas, os Yes Men não tinham nenhum treinamento teatral que os credenciassem como impostores críveis. No entanto, tinham rostos comuns e cara de pau o suficiente para passar por membros do segundo escalão da instituição. A expectativa era que, dado o grau dos absurdos que proferiam em suas aparições, eles seriam prontamente desmascarados e detidos, expulsos, repreendidos, ou coisa que o valha. Em vez disso, as pessoas vinham até eles para pedirem os seus

\footnotetext{
270 GATT é a sigla para General Agreement on Tariffs and Trade ("Acordo Geral em Tarifas e Comércio"), que
} era o acordo predecessor à instauração da OMC, em 1995. O site da OMC é www.wto.org 
cartões. Como diz Mike Bonanno, "quando você vai a uma conferência fingindo ser outra pessoa, é muito importante ter um cartão de visita. Isto é fundamental. Fora isto, não há muitas coisas necessárias" ${ }^{271}$.

A experiência em Salzburg demonstrou que "a plateia vinha com a desconfiança suspensa. Ou melhor, esta desconfiança nunca havia existido: eles sabiam que estavam diante de um representante da $\mathrm{OMC}^{272}$. Ou seja, analisando a partir da formulação de Féral, a plateia que assistia às aparições dos Yes Men era incapaz de fazer a clivagem entre real e ficcional. Esta cisão, e, portanto, a qualidade de teatralidade, só surgia após o prank revelado, seja na imprensa, no site ou nos filmes dos Yes Men.

Eles sentiam que seria preciso radicalizar ainda mais o teor das performances, com algo tão inaceitável que não permitisse a passividade da plateia. A oportunidade para isso surgiu com o convite (também recebido por meio do site fictício) para uma palestra no encontro "Fibras e tecidos para o futuro", promovido por uma associação de pesquisa têxtil na Finlândia, em agosto de 2001. Foi a deixa para a entrada em cena de Hank Hardy Unruh, representante da OMC designado pelos Yes Men para a palestra. Assim como Bichlbauer e Finisterra, quem "interpretou" Unruh foi Bichlbaum, mas dessa vez com uma elaborada produção de figurino. A razão para isso era a ideia que a OMC pretendia lançar na Finlândia como contribuição a um problema que preocupava todas as multinacionais: como gerenciar e manter o controle sobre trabalhadores situados em suas fábricas nos países do terceiro mundo? A solução era o "traje de lazer gerencial". Unruh teve seu terno arrancado na palestra e, sob ele, vestia um macacão de lamê dourado. Além de muito confortável, o "traje de lazer gerencial" tinha importantes inovações. Um falo gigante (o "apêndice de visualização laboral") se erguia até a face do usuário, apresentando a ele uma tela de monitoramento de seus trabalhadores distantes. A facilidade de operação do equipamento, sem o uso das mãos, deixava o gerente livre para a execução de atividades de lazer. Dois problemas resolvidos de uma só vez: lazer para o gerente, vigilância para os trabalhadores.

\footnotetext{
271 Em entrevista concedida a V. Vale in Pranks \#2, op. cit., p. 36.

272 THE YES MEN, op. cit., p. 41.
} 
Após a apresentação, uma animada salva de palmas. Nenhum desconforto, nenhuma indignação com os absurdos da palestra. Os organizadores do encontro agradeceram a Unruh por "mostrar o valor de sempre pensar com criatividade". Mais uma vez, apesar do evidente nonsense em ver um representante da OMC em um macacão dourado com um falo de um metro de comprimento, a descrença da plateia da falsa OMC estava suspensa. "Se eles nos seguem alegremente por estes caminhos de pesadelo, a verdadeira OMC deve convencê-los de qualquer coisa"273.

A esta altura, a OMC já estava suficientemente avisada dos pranks dos Yes Men, e já tinha espalhado a notícia na grande mídia. Ironicamente, isso ajudava os ativistas. O objetivo do que os Yes Men fazem é a cobertura de mídia, não a plateia de cem, duzentas pessoas que está presente nas palestras. Eles pretendem que, desvendados em publicações da grande mídia corporativa, seus pranks possam engajar alguns leitores ou telespectadores em ideias antiglobalização. "Nós fazemos tudo o que podemos para alcançar os meios de comunicação de massa e espalhar nossa mensagem pro maior número de pessoas possível" ${ }^{274}$. O contágio da ideia e a simpatia à causa dos Yes Men são potencializados pelo humor de seus pranks de simulação.

Mesmo contra todas as probabilidades, depois do prank na Finlândia, os Yes Men ainda receberam pedidos para falar como representantes da OMC. Uma associação de contadores de Sydney, Austrália, os convidou para a conferência "Negócios sem fronteiras", a ser realizada dali a seis meses. Eles dispunham de tempo de sobra para criar uma performance incrivelmente, insuperavelmente inadmissível. Os Yes Men conseguiram, inclusive, uma oportunidade para ensaiar sua apresentação. Um professor da State University of New York os convidou como representantes da OMC (cientes de que eles eram impostores), para proferir uma palestra para os alunos do curso de economia, em março de 2002.

A palestra "Novos horizontes na globalização do agronegócio do terceiro mundo" começou com o Dr. Kinnithrung Sprat, "representante" da OMC agradecendo

Ibid. p. 9.

274 Mike Bonanno, em entrevista concedida a V. Vale in Pranks \#2, op. cit., p. 33. 
a parceria com a empresa patrocinadora do evento, McDonalds, que gentilmente distribuiu hambúrgueres para todos os presentes. Sprat discorreu, então, sobre a proposta da $\mathrm{OMC}$ para contribuir com a solução do problema da fome nos países do terceiro mundo. A proposta estava baseada na constatação científica da ineficiência do organismo humano em absorver nutrientes da comida. Apenas $20 \%$ dos nutrientes são absorvidos no processo digestivo, o resto é desperdiçado em "subprodutos da digestão", segundo o eufemismo de Sprat. A proposta clamava pelo reaproveitamento de todo este potencial nutritivo desperdiçado nas latrinas do primeiro mundo. Através de um sistema de dutos ("similar aos usados para transportar óleo", Sprat acrescentou), o material que sai destas latrinas seria levado aos países de terceiro mundo e higienicamente filtrado para que pudesse virar novamente um delicioso hamburguer e alimentar a população carente. Sprat via nesta solução, batizada de "Re-burguer", a mais eficiente resposta que o livre mercado poderia dar ao problema da fome.

Os estudantes da State University ficaram indignados. Vários fizeram colocações que mostravam o descontentamento com o tratamento insensível e inumano proposto pela OMC. Chegaram inclusive a arremessar bolas de papel e restos de hambúrgueres no representante da instituição. Finalmente os Yes Men tinham conseguido mobilizar sua plateia.

Apesar da experiência com os alunos de economia ter sido bem sucedida, ficou claro para os Yes Men que a aparição na Austrália seria a última correção de identidade da OMC, e que era necessário um gran finale para sua série de pranks. Foi quando um colaborador dos Yes Men sugeriu que eles “encerrassem” a OMC.

Assim, em maio de 2002, quando o Dr. Kinnithrung Sprat iniciou sua palestra em Sydney, ele se desculpou pela repentina "mudança de planos" a que era obrigado em sua fala. Eventos ocorridos nos escritórios da OMC em Genebra, no dia anterior, levavam-no a alterar a palestra cujo tema original seria o comércio australiano de carne de carneiro e o comércio canadense de salmão. Sprat portava a mensagem de que a OMC tal como existia até então deixaria de existir e passaria por uma total reformulação visando não mais à maximização dos lucros das grandes empresas, mas 
objetivos humanitários. A nova organização teria sua base na Declaração Universal dos Direitos Humanos, da ONU, e adotaria uma política em que os países periféricos receberiam atenção prioritária. Não apenas todos os presentes acreditaram na fala de Sprat, como ficaram felizes com a nobreza do reconhecimento da necessidade de mudança de rota da organização. Um release de imprensa sobre o assunto foi mandado para 20 mil jornalistas de todo o mundo. Prontamente, a OMC teve de desmentir que estava encerrando as atividades em prol desta fictícia nova organização mais sensível às necessidades dos países pobres. Mais uma vez, os Yes Men conseguiram que a OMC revelasse sua verdadeira face, e os interesses a que ela atende.

Se a "correção de identidade" da OMC tinha chegado a um ponto culminante, o mesmo não poderia ser dito de outras instituições e empresas. A Dow Chemicals percebeu isto quando teve de prestar contas do porque não havia solucionado o imbróglio da Union Carbide em Bhopal. A gigante do mercado de petróleo, Exxon, e a Halliburton foram corporações que também sentiram os efeitos dos pranks dos Yes Men, tendo sido representadas por eles em diferentes ocasiões, sempre com um elevado nível de humor nonsense. Exemplo disso foi quando um falso representante da Halliburton apresentou o "Survivaball", um traje de sobrevivência para qualquer tipo de ataque terrorista ou catástrofe natural causada pelo aquecimento global, sejam tornados, tsunamis, terremotos, etc. O formato do "Survivaball" era uma ridícula bolha que cobria todo o corpo do usuário, deixando apenas seu rosto visível. Outra vez, em vez de se sentirem ultrajados, a plateia só se interessou pelos custos de produção.
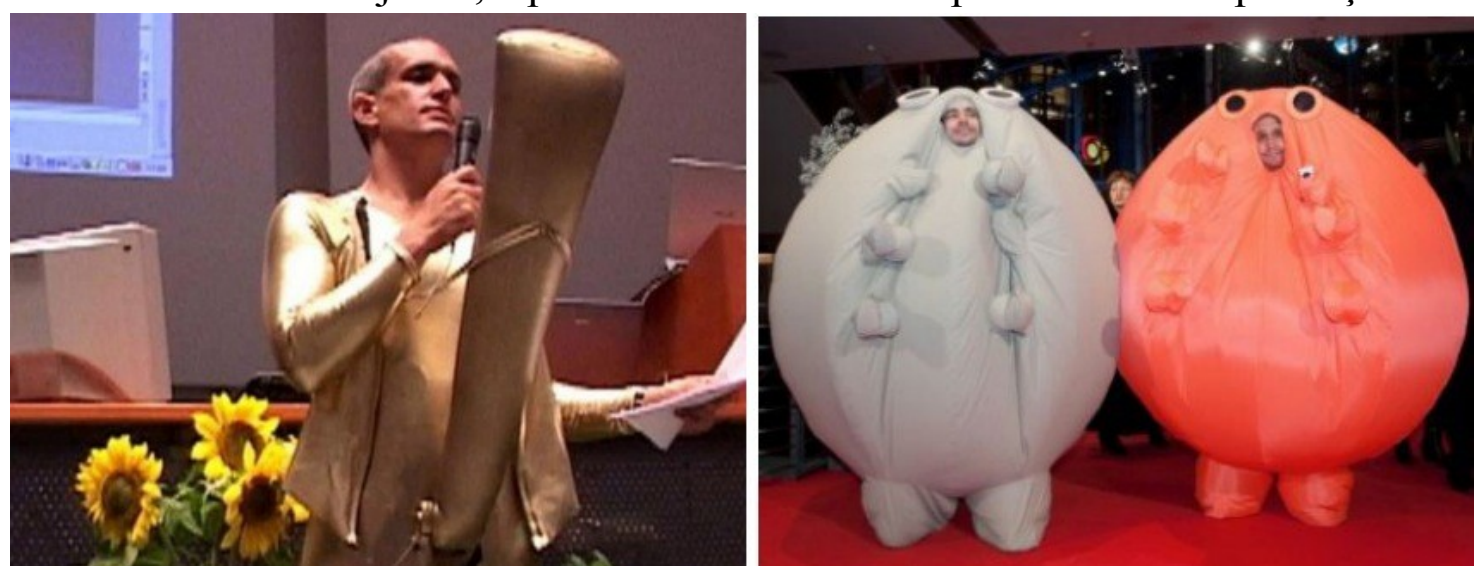

Figura 16: Esquerda: Hank Hardy Unruh, falso representante da OMC, com seu falo dourado, agosto de 2001, Tampere, Finlândia. Direita: Yes Men em seu traje anti-catástrofes, Survivaball, outubro de 2005 
A visibilidade dos pranks dos Yes Men atingiu o seu ápice em 12 de novembro de 2008. Colaborando com uma grande rede de ativistas, artistas, escritores, jornalistas e entusiastas de sua causa ${ }^{275}$, eles lançaram uma edição especial do jornal New York Times, com data de 04 de julho de 2009, oito meses no futuro, portanto. O lançamento do jornal impresso foi acompanhado por uma versão online do projeto $^{276}$.

A edição especial contava com várias notícias espetaculares, uma breve olhada no mundo "como ele deveria ser": o fim da guerra do Iraque; o autoindiciamento de Bush por crime de traição à pátria (com a declaração do ex-presidente "Milhões sofreram por meus pecados, e percebo agora que eu também devo sofrer"); um pedido de desculpas formal de Condoleeza Rice pelo pânico gerado pelas supostas "armas de destruição em massa" iraquianas; a promulgação de uma lei que estabelecia um teto salarial de 15 vezes o salário mínimo; a aprovação do sistema de saúde gratuito e universal nos EUA; o aumento das ciclovias de Nova York; o financiamento de programas de recuperação ambiental por parte das empresas petrolíferas; e demais notícias que a maioria dos leitores gostariam de ver estampadas no periódico.

Em vez de fazer o discurso do "imagine se o mundo fosse...", o prank do falso New York Times pretendia confrontar os leitores com um artefato por meio do qual eles fossem transportados a uma realidade alternativa, sobre a qual poderiam perguntar "por que não?". "Precisávamos mostrar com o que uma verdadeira mudança se parece. (...) Nós podemos fazer todas essas coisas. Se nós criamos o sistema que temos agora, porque não, em vez deste, criar um sistema bom?", perguntam os Yes $M^{2}{ }^{277}$.

$\mathrm{Na}$ manhã do dia 12 de novembro, diversos voluntários distribuíram gratuitamente o jornal pela cidade. A tiragem divulgada foi de 1,2 milhões de exemplares, mas Andy Bichlbaum admitiu posteriormente que tinha sido apenas de 80 mil exemplares e "inflada" na imprensa para aumentar a visibilidade do prank ${ }^{278}$. Um

\footnotetext{
275 A rede de grupos que participou da elaboração do prank incluía CODEPINK, Anti-Advertising Agency, May First/People Link, Evil Twin, Improv Everywhere e Not An Alternative, além de indivíduos como Steve Lambert e Stephen Duncombe.

276 A edição completa está em http://www.nytimes-se.com

277 No filme que eles próprios dirigiram: BICHLBAUM, e BONANNO, op. cit.

278 Andy admite isso em vídeo disponível no site de Steve Lambert, Andy Bichlbaum and Steve Lambert Interview. Disponível em http://visitsteve.com/work/the-ny-times-special-edition/
} 
dos pontos de distribuição era justamente em frente à sede do NY Times, e os jornalistas do periódico não pareceram nem um pouco entusiasmados com o prank. Vários transeuntes, no entanto, após uma primeira reação de espanto e confusão (muitos perguntando "isso é real?", "é mentira, né?”, “quem publicou isso?”, “é bom demais para ser verdade"), aprovaram a iniciativa do projeto. A atriz Lili Taylor, que recebeu um exemplar, declarou "acho que temos que exercitar músculos que, ou não temos, ou estão atrofiados: o músculo cívico, o músculo da parcimônia, o músculo da generosidade". A professora de ciências políticas, France Fox Piven, disse "nós podemos pensar diferentes maneiras de contribuir com um movimento que diz que o estado de coisas como está é inaceitável (...), não vamos desempenhar o papel subserviente e rotineiro que desempenhamos normalmente" 279.

A repercussão do prank na mídia foi estrondosa. CNN, NBC, BBC, Reuters, Associated Press e outras agências de notícias e redes de comunicação cobriram o prank, divulgando-o mundialmente. Seu objetivo de amplificar a mensagem para um grande número de pessoas foi atingido, mas, mais importante, os Yes Men tiveram demonstrações de um desejo de engajamento político de pessoas até então nãoativistas a partir de seu prank.

O objetivo dos pranks dos Yes Men, da Adbusters, da Billboard Liberation Front, do Yomango, e de vários outros grupos ativistas dedicados à guerrilha de comunicação é um contra-ataque no terreno dos meios de comunicação, na esfera midiática dominada pelo capital. É uma resposta às imagens massificantes que ditam nossa experiência social. Como afirma Marc Dery, "combater simbolismo com contrasimbolismo é uma parte essencial de qualquer estratégia ativista" ${ }^{280}$. Neste espaço midiático colonizado, assim como no espaço físico urbano, os ativistas precisam investir seus esforços em descobrir modos eficientes de oferecer resistência. A recorrente opção pelos pranks tem oferecido uma alternativa positiva. 


\section{CONCLUSÃO}

A prank a day keeps the dog leash away ${ }^{281}$

Jello Biafra

Em 1794, o poeta romântico alemão Friedrich Hölderlin escreveu a seu amigo C. L. Neuffer: "Dane-se! Se for necessário, quebraremos nossas pobres liras e faremos o que os artistas apenas sonharam!"282. O desejo de afecção dos artistas, muito mais antigo do que Hölderlin, faz reaparecer com frequência a mesma exortação de ruptura das fronteiras que supostamente separam a criação artística da prática política. As "pobres liras" podem ser outras, e mesmo outros os sonhos dos artistas. Mas continua constante a sensação de que, do sonho, é preciso passar à ação. Esta transição interessa a uma grande parte de arte contemporânea que chama a minha atenção como espectador e pesquisador, e também interessa à arte que me esforço pessoalmente em construir. No entanto, foi uma outra exortação de ruptura de fronteiras supostas, no sentido contrário, que me conduziu a esta pesquisa por conta de sua ânsia em incorporar de elementos artísticos.

O ativismo político contemporâneo precisou se reconfigurar quando o modo de produção a que ele resiste se reconfigurou. Esta nova configuração de ambos, em rede, aumentou a fluidez e a desterritorialização de suas práticas e se articulou com a emergência das imagens como elemento organizador da experiência social. Isto sublinhou decisivamente o papel da estética tanto na composição do poder dominante quanto na resistência a ele. A solicitação ao exercício político, portanto, foi a de que ele dialogasse com caracteres estéticos. Assim, tanto a arte com ambição análoga a de Hölderlin "vaza" em direção à ação política quanto o ativismo político contemporâneo requisita a inspiração, a fruição, a vivência e a performatividade da arte.

Neste contexto, o prank, prática lúdica, desobediente e insubordinada, aparece como um mediador que escapa a categorias estanques. O prank atende ao

\footnotetext{
281 "Um prank por dia evita a coleira".

282 apud. JAPPE, op. cit., 1999, p. 97.
} 
objetivo indisciplinar de solapar fronteiras entre arte, política e ativismo, na direção da construção de um imaginário e de um processo coletivo de retomada do comum. Este comum está expresso em diversas esferas da experiência social. Uma fração importante desta experiência que vem sendo objeto de disputa de ativistas que adotam o prank como opção performativa é o espaço, entendido tanto como espaço físico, onde a urbe se funda, quanto como espaço ideológico, imaterial, onde se dão as trocas simbólicas. Desta forma, por mais que difiram em estratégias, métodos, ou alvos, coletivos como Reclaim the streets, Delinquentes, Inconsequentes e Dementes, Yomango, ou outros tantos abordados ao longo deste trabalho, dedicam-se igualmente a resistir e a disputar um espaço no qual eles enxergam a emergência do comum, de algo que não pode ser cercado pelos conceitos de propriedade e de exclusividade.

Quando a representação política tradicional (estou pensando prioritariamente em partidos políticos, sindicatos, algumas organizações não governamentais) tem um modo linear de pensamento, ela tende a elaborar suas ações sobre uma relação causal que terá um desdobramento futuro. $\mathrm{O}$ que faz o ativismo político contemporâneo optar por práticas como o prank (e que o diferencia da representação política tradicional) é a possibilidade de criar espaços nos quais coisas impossíveis mas desejadas sejam vividas por uma fração de tempo. As performances dos pranks já demonstram como os ativistas pretendem viver, não objetivam apenas desdobramentos, mas, sobretudo, a experiência desta vivência em si. Não se trata apenas de projetar um mundo novo, a ser conquistado, um amanhã melhor, mas sim uma reapropriação da vida no agora, neste momento. Estes instantes de irrupção, de insurgência, de levante, são altamente performativos. O conceito de Zona Autônoma Temporária, de Hakim Bey, ilustra bem a qualidade impermanente destes momentos. São aventuras envolventes, indetermináveis, instáveis, coletivas (mesmo quando realizadas individualmente) e retroalimentadoras, já que inspiram outras performances que também serão instantes de irrupção.

O recorrente uso do humor, da ironia, da paródia, do ridículo no prank comunica a resistência como um espaço de criatividade, não apenas artística, mas 
também política. As autoridades costumam estar preparadas para as oposições físicas, jurídicas ou diplomáticas, mas menos preparadas para reagir ao humor crítico. $\mathrm{O}$ humor e a criatividade demonstram que não é preciso ser um perito em política ou em arte para participar do processo, já que diferentes manifestações são válidas e podem ser abrigadas pela rede. Deste modo, funcionam como um passaporte de entrada para aqueles que não estão engajados com a rede de ativismo político contemporâneo, mas que pretenderiam estar.

O engajamento também é debitário de uma qualidade correlata ao humor, que é o jogo, a brincadeira. A ludicidade dos pranks cumpre, ao mesmo tempo, uma tarefa de proporcionar prazer, e outra de estabelecer parâmetros pedagógicos. Muitos pranks pretendem direcionar o olhar dos espectadores para algum assunto que se encontra camuflado, inacessível, afastado da análise pública. É o caso, por exemplo, do prank dos Yes Men sobre a Dow Chemical, assumindo a responsabilidade pelo desastre industrial em Bhopal. $\mathrm{O}$ aspecto lúdico neste caso chama a atenção pela ridicularização da corporação, mas, sobretudo, traz para o centro das discussões um evento não resolvido da história e sobre o qual não se costuma ter informações suficientes, cumprindo sua função pedagógica (quase jornalística) de divulgação.

O caráter de emancipação estética do prank demonstra a relação íntima de sua estrutura com a da performance art. Um valor preponderante em ambos é a capacidade de autoexpressão, politicamente manifesta no que Brian Holmes chamou de "geopolítica do faça você mesmo". Na performance atravessada pelo prank não existem mediadores, ela é autônoma, autogerida, avessa a lideranças, hierarquias ou delegações. Assim como um performer de performance art, o prankster é sujeito e objeto de sua performance, e é por este motivo que o conceito de "representação direta" proposto por Holmes é apropriado para esta análise ${ }^{283}$. Ele significa que o sujeito em performance ao executar o prank tem um caráter duplo, ao mesmo tempo signo e agente. Seu exercício estético corresponde ao seu exercício político ou,

\footnotetext{
283 Ainda que se possa fazer a ressalva quanto à escolha da palavra "representação", conforme discutido no segundo capítulo desta tese.
} 
conforme Holmes esclarece, "o processo de feitura do gesto [estético] é o processo da ação política, a maneira de se fazer o gesto é a cultura da ação política" ${ }^{284}$. Há no prank, portanto, uma indissociabilidade entre o gesto estético e gesto político de forma que qualquer estabelecimento de fronteiras que isolem estas esferas torna-se analiticamente ineficiente.

Os dois eixos de análise a partir dos quais Josette Féral busca apreender experiências do teatro contemporâneo, a teatralidade e a performatividade, iluminam diferentes qualidades das performances dos pranks, e por isso colaboram para seu estudo. A teatralidade é central para avaliar a operação de clivagem entre o real e o simulado, entre cotidiano e simbólico, na modalidade de prank de simulação. Quando se estabelecem dois níveis de audiência, o primeiro dos quais ignorando e o segundo compartilhando a intenção teatralizante do prankster, o recurso disjuntivo presente na teatralidade oferece para um ativista uma ferramenta eficiente de atuação política.

A performatividade, por sua vez, em vez de ressaltar uma fissão entre o simbólico e o real, enfatiza a qualidade de evento, de acontecimento presente e autoexpressivo que é a tônica dos pranks de situação, ou de alguns pranks de armadilha. $\mathrm{O}$ risco real do processo performativo evidencia a materialidade dos pranks, que por um lado cobra uma avaliação de seus desempenhos, por outro sublinha seus aspectos lúdicos.

Os pranks de comentário têm a característica de abordar fragmentos preexistentes de cultura para se posicionar politicamente em relação a eles. Atualmente, com o que chamei (aproveitando a crítica debordiana) de entrelaçamento entre o modo de produção e sua representação, a recontextualização crítica das imagens recorre à sua profusão nos meios de comunicação de massa, na indústria cultural, na publicidade. Esta é a atitude central do culture jamming e, ainda que se possa perceber uma capacidade de cooptação mercantil de alguns padrões rebeldes desta prática (como visto no terceiro capítulo, em relação ao sucesso comercial das obras de Banksy, ou à incorporação do subvertising da Adbusters, como no exemplo

$284 \quad$ Entrevista em anexo. 
da marca Ecko), as práticas de prank que adotam esta estratégia costumam ser eficazes em suas performances críticas. Enquanto atuam no "território inimigo", transformam imagem em "contra-imagem", tomando o domínio da publicidade e da mídia em um momento fugidio de ataque, e então desaparecem, diluem-se na rede, para tomar forma em outro lugar. A sede pelo novo, pelo atual, pelo cool que orienta a organização social e econômica no capitalismo contemporâneo tem fissuras e espaços não cobertos que os ativistas pranksters buscam ocupar para resistir.

$\mathrm{O}$ "desafio direto às rotinas verbais e comportamentais" e "a profunda e duradoura desconfiança sobre as convenções sociais" que Vale imputa aos pranks os faz atraentes como opção performativa tanto para os ativistas dedicados às macroações políticas dos Dias de Ação Global, quanto para os ativistas dedicados às microações políticas diluídas no cotidiano. Esta atração só ocorre porque o campo híbrido instaurado pelos pranks é um espaço lúdico, vivencial e multiplicador. 


\section{REFERÊNCIAS BIBLIOGRÁFICAS}

\section{Livros:}

AGUINTON, Christophe. O mundo nos pertence. São Paulo: Viramundo, 2002.

BAKHTIN, M. A cultura popular na Idade Média e no Renascimento - o contexto de François Rabelais. São Paulo: Hucitec/ UnB 1999.

BANKSY. Wall and Piece. Londres: Century, 2005.

BARTHES, Roland. O rumor da língua. São Paulo: Brasiliense, 1988.

BENJAMIN, Walter. Obras escolhidas III: Charles Baudelaire, um lírico no auge do capitalismo. São Paulo? Brasiliense, 1989.

BESANÇON, Julien (org). Les murs ont la parole - mai 68. Paris: Tchou, 2007.

BEY, Hakim. Caos - terrorismo poético e outros crimes exemplares. São Paulo: Conrad, 2003.

TAZ - Zona autônoma temporária. São Paulo: Conrad, 2001. Col. Baderna.

BLISSETT, Luther. Guerrilha psíquica. São Paulo: Conrad, 2001. Col. Baderna.

BOAL, Augusto. Teatro do oprimido e outras poéticas políticas . 5a. edição. Rio de Janeiro: Civilização Brasileira, 1988.

CANEVACCI, Massimo. Culturas eXtremas: mutações juvenis nos corpos das metrópoles. Rio de Janeiro: DP\&A, 2005.

CARERI, Francesco. Walkscapes: el andar como práctica estética. Barcelona: Ed. Gustavo Gili, 2007. Land\&Scapes Series.

CHOMSKY, Noam. 11 de setembro. Rio de Janeiro: Bertrand Brasil, 2002.

CHRISPINIANO, José. A guerrilha surreal. São Paulo: Conrad e Com-Arte, 2002.

COHEN, Renato. Performance como linguagem. São Paulo: Perspectiva, 1989.

DEBORD, Guy. A sociedade do espetáculo e Comentários sobre a sociedade do espetáculo. Rio de Janeiro: Contraponto, 1997.

Oeuvres. Paris: Gallimard, 2006.

DELLA PORTA, Donatella. The global justice movement: cross-national and transnational perspectives. Nova York: Paradigm, 2006.

FOUCAULT, Michel. O que é um autor? Lisboa: Passagens, 1992.

GENNARI, Emilio. EZLN - passos de uma rebeldia. São Paulo: Expressão Popular, 2005. 
GLUSBERG, Jorge. A arte da performance. São Paulo: Perspectiva, 2005.

GRAY, John. Al Qaeda and what it means to be modern. Londres: Faber e Faber, 2003.

HARDT, Michael e NEGRI, Antonio. Multidão. Rio de Janeiro: Record, 2005.

HOBSBAWM, Eric. Globalização, democracia e terrorismo. São Paulo: Cia das Letras, 2007

HOLLOWAY, John. Change the world without taking power. Londres: Pluto Press, 2002.

HOLMES, Brian. Unleashing the collective phantoms: essay in reverse imagineering. Nova York: Autonomedia, 2008.

HOME, Stewart. Assalto à cultura: utopia, subversão, guerrilha na (anti) arte do século XX. São Paulo: Conrad, 2004.

INDA, Jonathan Xavier e ROSALDO, Renato (orgs.). The anthropology of globalization. Oxford: Blackwell, 2008.

INTERNACIONAL SITUACIONISTA. Deriva, psicogeografia e urbanismo unitário. Porto Alegre: Deriva, 2007.

Apologia da deriva - escritos situacionistas sobre a cidade. Rio de Janeiro: Casa da Palavra, 2003.

--------------. Situacionista - teoria e prática da revolução. São Paulo: Conrad, 2002. Col. Baderna.

JAPPE, Anselm. Guy Debord. Petrópolis: Vozes, 1999.

JURIS, Jeffrey S. Networking futures - the movements against corporate globalization. Durham: Duke University Press, 2008.

KINGSNORTH, Paul. Um não, muitos sins - uma viagem aos centros da antiglobalização. Rio de Janeiro: Record, 2006.

KLEIN, Naomi. Sem Logo. Rio de Janeiro: Record, 2002.

The shock doctrine - the rise of disaster capitalism. Nova York: Metropolitan Books, 2007.

LUDD, Ned. (org.) Urgência das ruas - Black Bloc, Reclaim the Streets e os Dias de Ação Global. São Paulo: Conrad, 2002. Col. Baderna.

MASON, Matt. The pirate's dilemma - how hackers, punk capitalists and graffiti millionaires are remixing our culture and changing the world. Londres: Allen Lane, 2008.

MCKAY, George (org.) DIY culture - party \& protest in nineties Britain. Londres: Verso, 1998.

MCKENZIE, Jon. Performance or else - from discipline to performance. Nova York: Routledge, 2001. 
MERTES, Tom (org). A movement of movements - is another world really possible? Londres: Verso, 2004.

NOTES FROM NOWHERE. We are everywhere - the irresistible rise of global capitalism. Londres: Verso, 2003.

RAUEN, Margarida Gandara (Margie) (org.). A interatividade, o controle da cena e o público como agente compositor. Salvador: EDUFBA, 2009.

RAUNIG, Gerald. Art and revolution: transversal activism in the long twentieth century. Los Angeles: Semiotext(e), 2007.

RICHARDSON, Joanne (org.). An@architexts: voices from the global digital resistance. New York: Autonomedia, 2003.

RYOKI, André e ORTELLADO, Pablo. Estamos vencendo - resistência global no Brasil. São Paulo: Conrad, 2004. Col. Baderna.

SCHECHNER, Richard. Between theater \& anthropology. Filadélfia: University of Pennsylvania Press, 1985.

Performance studies: an introduction. Londres e Nova York: Routledge, 2006.

Performance theory. Londres e Nova York: Routledge, 1988.

SUBCOMANDANTE MARCOS. Conversations with Durito: stories of the Zapatistas and neoliberlism. Nova York: Autonomedia, 2005.

TAYLOR, Roger. Arte, inimiga do povo. São Paulo: Conrad, 2005.

THE YES MEN. The Yes Men: the true story of the end of the World Trade Organization. Nova York: Disinformation, 2004.

TRAPESE COLLECTIVE. Do it yourself: a handbook for changing the world. Londres: Pluto Press, 2007.

VIRILIO, Paul. O espaço crítico. Rio de Janeiro: Ed. 34, 1993. Col. Trans.

\section{Textos em sites:}

"10 claves para un estilo de vida Yomango". Disponível em http://www.sindominio.net/ fiambrera/007/ymng/claves.htm. Acesso em 30 de abril de 2010.

ALMEIDA, Ari. Manual Prático de Delinquência Juvenil. Disponível em http://www.delinquente.blogger.com.br/ - Acesso em 15 de junho de 2004. http://www.delinquente.blogger.com.br/ - Acesso em 26 de maio de 2007.

"Barbie Liberation Organization". Disponível em http://www.vdb.org/smackn.acgi\$ artistdetail?BARBIELIBE Acesso em 21 de abril de 2010. 
BERARDI (BIFO), Franco. "Desobedience and Cognitariat". Disponível em www.pushthebuttonplay.com/dlwd/ scotini/disobedience/pdf/interview bifoscotini en. pdf - Acesso em 15 de maio de 2008.

BUCCI, Eugênio. "O olho da gente no olho do furacão". Disponível em http://jbonline.terra.com. br/destaques/g8/g82607olho.html - Acesso em 01 de fevereiro de 2006.

BUI, Roberto. "Nenhuma Derrota é Definitiva". Mensagem pessoal recebida por e-mail em 22 de maio de 2008. Disponível em http://fsalvatti.blogspot.com/2008/05/nenhumaderrota-definitiva.html

BUZZELL, Colby. "I am Banksy". Revista Esquire, 30/11/05. Disponível em http://www.esquire.com/features/best-n-brightest-2005/ESQ1205BANKSY 198?click = main sr - Acesso em 05 de fevereiro de 2010.

CLEAVER, Harry. "Computer-linked Social Movements and the Global Threat to Capitalism". Disponível em http://www.eco.utexas.edu/faculty/Cleaver/polnet.html Acesso em 31 de maio de 2009.

DERY, Mark. "Culture jamming: hacking, slashing and sniping in the empire of signs". Disponível em http://www.markdery.com/archives/books/culture jamming/ - Acesso em 12 de abril de 2010.

DUARTE, João Ferreira. "Carnavalização". Disponível em http://www.fcsh.unl.pt/edtl /verbetes/C/carnavalizacao.htm Acesso em 15 de outubro de 2009

GOLDFARB, Michael. "Living under the CCTV gaze" Disponível em http://www.globalpost.com/dispatch/united-kingdom/090328/living-under-the-cctv-gaze Acesso em 15 de janeiro de 2010.

HATTENSTONE, Simon. "Something to spray". The Guardian, 17/07/03. Disponível em http://www.guardian.co.uk/artanddesign/2003/ jul/17/art.artsfeatures - Acesso em 12 de abril de 2010.

HOOPER, John. "Genoa officer in 'suspicious' car crash". The Guardian. 06/08/03. Disponível em http://www.guardian.co.uk/world/2003/aug/06/globalisation.italy Acesso em 20 de junho de 2009.

JUNG, Jenny. "Performing a mob" Disponível em http://www.fdcw.org/0708/jung2/ - Acesso em 05 de janeiro de 2010 .

KARLOFF, Boris. "Resisting Zombie Culture", disponível em www.uncarved.org/turb/ articles/karloff.htm - Acesso em 03 de maio de 2009.

KLEIN, Naomi. "What Happened with the New Left? - The Hijacking of the WSF". Disponível em http://www.nadir.org/nadir/initiativ/agp/free/wsf/naomiklein.htm Acesso em 10 de junho de 2009.

MARX, Karl. "Teses sobre Feuerbach”, disponível em http://www.marxists.org/portugues/

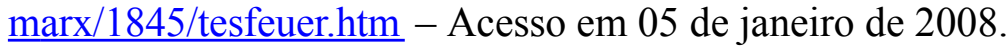


MINOR, Vernon Hyde. "What Kind of Tears? 9/11 and the Sublime". Disponível em http://www.bilkent.edu.tr/ jast/Number14/Minor.htm - Acesso em 10 de julho de 2007.

ORTELLADO, Pablo. "Whose Movement?" Disponível em http://www.nadir.org/nadir/ initiativ/agp/free/wsf/whosemovement.htm - Acesso em 10 de junho de 2009.

"Princípios da AGP". Disponível em http://www.nadir.org/nadir/initiativ/agp/pt/hallmpt.htm Acesso em 13 de janeiro de 2009.

SANT'ANNA, Antonio C. V. e SALVATTI, Fabio. "De Luther Blissett a Wu Ming". Disponível em_www.casthalia.com.br/casthaliamagazine/casthaliamagazine4.htm

SILVEIRA, Sérgio Amadeu da. "O Conceito de Commons". Disponível em http://www.aepidemia.org/noticia/commons-cibercutura - Acesso em 15 de maio de 2008.

"Sobre o programa Mob Brasil". Disponível em http://multishow.globo.com/MOBBrasil/Sobre-o-Programa/ Acesso em 15 de março de 2010.

SUBCOMANDANTE MARCOS. "Comunicado de Imprensa do Subcomandante Marcos, 28 de Maio de 1994". Disponível em http://www.bibliotecas.tv/chiapas/may94/ 28may94.html - Acesso em 20 de maio de 2009.

WASIK, Bill. "My crowd: or, phase 5: a report from the inventor of the flash mob". Disponível em http://goliath.ecnext.com/coms2/gi 0199-5337724/My-crowd-or-phase$\underline{5 . h t m l}$ - Acesso em 18 de janeiro de 2010.

"Waterfight in Stanley Park, but are flash mobs starting to lose their edge?". Vancouver Sun, 12 de julho de 2008. Disponível em http://www.canada.com/vancouversun/news/ story.html?id=f4b1b51f-1340-46b3-8c14-97405c63b5fe - Acesso em 05 de janeiro de 2010.

WATTERS, Audrey. “'We can lick the upper crust' - pies as political pranks". Disponível em http://www.audreywatters.com - Acesso em 12 de maio de 2009.

WU MING. "Tute Bianche: o lado prático da produção de mitos (em tempos catastróficos)". Disponível em: http://www.rizoma.net/interna.php?id=142 \&secao=intervencao

------------. "Zapatismo ou barbárie". Disponível em http://www.wumingfoundation.com/ italiano/outtakes/zapatismo port.html - Acesso em 31 de maio de 2009.

\section{Sites:}

http://artists-anonymous.com/

http://bhopal.org

http://enlacezapatista.ezln.org.mx

http://seattle.indymedia.org

$\underline{\text { http://tanks-alot.co.uk/ }}$ 
http://theyesmen.org

https://www.adbusters.org/

http://www.afed.org.uk/online/j18/index.html

http://www.banksy.co.uk/

http://www.bibliotecas.tv/chiapas/comunicados sub.html

http://www.billboardliberation.com

http://www.delinquente.blogger.com.br

http://www.forumsocialmundial.org.br

http://www.forumpermanente.org

http://www.hamacaonline.net/

http://www.lutherblissett.net

http://www.midiaindependente.org

http://www.nadir.org/nadir/initiativ/agp/index.html

http://www.nimportequi.com

http://www.nytimes-se.com

http://www.publicadcampaign.com/

http://www.spacehijackers.co.uk/

http://www.stillfree.com/

http://www.streettraining.org

http://www.thefuntheory.com/

http://www.thisisliveart.co.uk

http://www.wto.org

http://www.wumingfoundation.com

http://www.yomango.net/

http://www.yomango.org

\section{Artigos, teses e dissertações:}

ASSIS, Érico Gonçalves de. Bagunçando a cultura: interferência e criatividade como tática de protesto. Artigo apresentado ao Programa de Pós-Graduação em Ciências de Comunicação da UNISINOS, São Leopoldo, 2004. 
Táticas lúdico-midiáticas no ativismo político contemporâneo. Dissertação de mestrado apresentada ao Programa de Pós-Graduação em Ciências de Comunicação da UNISINOS, São Leopoldo, 2006.

BENNATON, Pedro Diniz. Deslocamento e invasão: estratégias para a construção de situações de intervenção urbana. Dissertação de mestrado apresentada ao Programa de Pós-Graduação em Teatro do CEART - UDESC, Florianópolis, 2009.

BELL, John. "Performance Studies in an Age of Terror". TDR. vol. 47. Nova York: NYU, Verão 2003.

BERNSTEIN, Ana. Of the body / of the text: desire and affect in performance. Tese de doutorado apresentada ao Departmento de Performance Studies da New York University, 2005.

DI GIOVANNI, Júlia Ruiz. Seattle, Praga, Gênova: política antiglobalização pela experiência da ação de rua. Dissertação de mestrado apresentada ao Programa de PósGraduação em Antropologia Social da FFLCH - USP, 2007.

FÉRAL, Josette. "Por uma poética da performatividade: o teatro performativo" in Sala Preta No. 8 - Revista do Departamento de Artes Cênicas da USP. São Paulo, 2008.

"Theatricality: The specificity of theatrical language". Substance 98/99, vol. 31, n. 2 e 3, 2002.

JAPPE, Anselm. “A arte de desmascarar". Folha de São Paulo, caderno MAIS!, páginas 4-5, 17 de agosto de 1997.

MESQUITA, André. Insurgências Poéticas - arte ativista e ação coletiva (1990-2000). Dissertação de mestrado apresentada ao Programa de Pós-Graduação em História da FFLCH - USP. São Paulo, 2008.

MÜLLER, Regina P. "Corpo em movimento e sujeito-personagem: discussão teóricometodológica sobre uma pesquisa em dança indígena" in Anais do V Congresso Brasileiro de Pesquisa e Pós-Graduação em Artes Cênicas. Belo Horizonte, 2008, disponível em http://www.portalabrace.org/vcongresso/resumospesquisadanca.html Acesso em 30 de novembro de 2009.

SALVATTI, Fabio. "Eu sou ele assim como você é ele assim como você sou eu e nós somos todos juntos - elementos performáticos e subversivos em Luther Blissett". in MEMÓRIA ABRACE VII - Anais do III Congresso Brasileiro de Pesquisa e Pósgraduação em Artes Cênicas. Associação Brasileira de Pesquisa e Pós-graduação em Artes Cênicas. Florianópolis, 2003.

A plagiocombinação como estratégia dramatúrgica na cibercultura. Dissertação de mestrado apresentada ao Programa de Pós-Graduação em Teatro do CEART UDESC, Florianópolis, 2004.

"'Vocês, G8, Nós, 6 Bilhões' - Um Olhar Espetacular sobre as Manifestações em Gênova". in MEMÓRIA ABRACE X - Anais do IV Congresso Brasileiro de Pesquisa e Pós-graduação em Artes Cênicas. Associação Brasileira de Pesquisa e Pós-graduação em Artes Cênicas. Rio de Janeiro, 2006. 
VILLAR, Fernando Pinheiro. "Interdisciplinaridade artística e La Fura dels Baus: outras dimensões em performance", O Teatro Transcende, v. 11, Blumenau, 2002.

\section{Revistas:}

Desacuerdos \#2. Barcelona: Arteleku, MacBa e Unia, 2005.

Do or Die \#8. Disponível em http://www.eco-action.org/dod/no8/carnival.html . Acesso em 23 de setembro de 2008 .

Pranks \#2 San Francisco: RE/Search Publications, 2006.

RE/Search \#11: Pranks, San Francisco: RE/Search Publications ,1986.

\section{Filmes e vídeos:}

Andy Bichlbaum and Steve Lambert Interview. Disponível em http://visitsteve.com/work/theny-times-special-edition/

ARTIGAS, Xavi e MARTIN, Leónidas. Metropolis - Arte y activismo. Documentário veiculado pela emissora espanhola TVE 2 em 28 de fevereiro de 2010. Disponível em http://www.rtve.es/mediateca/videos/20100301/metropolis---arte-activismo/ 707244. $\underline{\text { shtml. }}$.

BICHLBAUM, Andy e BONANNO, Mike. The Yes Men fix the world. 2009.

Flash Mob - BEP - I Gotta Feeling., 2009. Disponível em http://www.youtube.com/watch? $\underline{\mathrm{v}=\mathrm{eyLuIY} 8 \mathrm{IyO} 4}$

FRIEDBERG, Jill e ROWLEY, Rick. This is what democracy look like, 2000.

NOWAK, Larissa. Street Training, 2008. Disponível em http://www.youtube.com/watch? $\underline{\mathrm{v}=41 \mathrm{mlwRaeybI}}$

OLLMAN, Dan; PRICE, Sarah e SMITH, Chris. The Yes Men, 2003.

Piano stairs., 2009. Disponível em http://www.youtube.com/watch?v=21Xh2n0aPyw

SALVATTI, Fabio. London MayDay 2008, 2008. Disponível em http://www.youtube.com/ watch?v=pjR9jCjRVkM

Teatro/Mercadoria., 2007. Disponível em http://www.youtube.com/watch?v=yMZSUW4JonI

The T-Mobile Dance. Disponível em http://www.youtube.com/watch?v=VQ3d3KigPQM

The world's deepest bin. Disponível em http://www.youtube.com/watch?v=cbEKAwCoCKw

TOWSEND, Stuart. Battle in Seattle, 2007.

WEINGARTNER, Hans. Die fetten Jahre sind vorbei (Edukators), 2004.

YOMANGO. Presentación oficial de la marca en sociedad. Disponível em http://www.youtube.com/watch?v=wED5Zn0k8fE 
Yomango-Tango. Disponível em http://www.youtube.com/watch?v=rXBSAubWc1A

\section{Outros:}

CHILD, Lottie (org.) Street Training Manual. Brochura-panfleto. Londres, 2007.

PARAVIDINO, Fausto. Gênova 01. Texto teatral não publicado. 


\section{CRÉDITOS DE IMAGENS}

FIGURA 1: Fabio Salvatti

FIGURA 2: Esquerda: Andrew Testa em NOTES FROM NOWHERE. We are everywherethe irresistible rise of global capitalism. Londres: Verso, 2003, p. 60. Direita: Andrew Wiard em NOTES FROM NOWHERE. We are everywhere - the irresistible rise of global capitalism. Londres: Verso, 2003, p. 173.

FIGURA 3: Esquerda: http://la-rage.blogspot.com/2007/09/ttica-dos-black-block.html. Direita: http://la-rage.blogspot.com/2007/09/ttica-dos-black-block.html.

FIGURA 4: Esquerda:http://www.flickr.com/photos/agitazioni/119427063/. Direita: Oriana Eliçabe em http://www.flickr.com/photos/orianomada/52665723/in/set-1121761/.

FIGURA 5: Esquerda: Agus Estrella em http://www.flickr.com/photos/agusestrella/ 151620113/in/photostream/. Direita: http://www.lutherblissett.net/img/luther-blissett300.jpg.

FIGURA 6: Esquerda: http://www.streettraining.org/view/images?page=10 .Direita: John Clare em http://www.streettraining.org/view/images?page $=18$.

FIGURA 7: Esquerda: João Vítor em http://www.streettraining.org/view/images?page=8 Direita: http://www.streettraining.org/view/images?page=19.

FIGURA 8: Esquerda: http://chantsdeluttes.free.fr/mai68/images68/affiches/100a199/ 127.jpg. Direita: Marc Riboud em http://www.marcriboud.com/marcriboud/europe/ MAI68/pages/MAI68-09.html.

FIGURA 9: Esquerda e Direita: Fabio Salvatti

FIGURA 10: Esquerda e Direita: http://www.spacehijackers.org/html/projects/dsei07/ tuesday.html

FIGURA 11: Esquerda: http://www.satanslaundromat.com/sl/archives/000068.html. Direita: http://www.satanslaundromat.com/sl/archives/000108.html.

FIGURA 12: http://www.27east.com/story_detail.cfm?id=145820 .

FIGURA 13: Esquerda: http://www.heliumfoundation.com/vault//artwork/banksy queen victoria.jpg. Direita: http://files.myopera.com/csant/blog/banksy.jpg.

FIGURA 14: Esquerda e Direita: Scott Beale em http://www.flckr.com/photos/ laughingsquid.

FIGURA 15:Esquerda e Direita: https://www.adbusters . org/gallery/spoofads.

FIGURA 16: Esquerda: http://cdn.mos. totalfilm.com/images/t/the-yes-men-800-75.jpg).

Direita: http://blogs.artvoice.com/avdaily/wp-content/uploads/2010/01/The-Yes-Men . preview.jpg). 


\section{ANEXOS \\ ENTREVISTA COM BRIAN HOLMES}

No livro "Unleashing the Collective Phantoms" ["Libertando os Fantasmas Coletivos"] você põe a questão: "Podemos realmente construir uma rede de resistência ao capitalismo?" E você diz que as primeiras respostas a essa questão são culturais ou artísticas. Como podemos desenhar uma "poética da resistência", pensando nos últimos quinze anos?

Quando eu digo que as primeiras respostas são culturais eu estou pensando em termos de ordem. É isso que vem antes. O único caminho para espalhar o desejo e, em seguida, a vontade das pessoas em se engajar em atividades de resistência é através da criação de atitudes, de relações com outras pessoas e com o espaço público ou assuntos públicos. Isso vem antes da criação de uma lei ou de qualquer coisa do tipo. A sociedade muda antes que a lei mude. Analisar os problemas tem seu papel também, e talvez venha antes, mas isso tem sido feito por um longo tempo. O tipo de problemas de que estamos falando já foram analisados há trinta, quinze anos. De certa forma, não tem havido "novas análises". O que é novo é que estas análises têm encontrado a cultura. Começa como um ato artístico singular que, ao ser compartilhado, se torna cultura. E então há uma maior elaboração desse tipo de gesto, desta atitude, desta postura que é tomada em relação ao resto do mundo.

É como se a cultura estivesse à frente da sociedade e que então mudaria antes da sociedade?

$\mathrm{Na}$ verdade eu acho que há um elemento de intervenção, que no início é bastante singular, e neste sentido é como a arte. A mudança cultural acontece quando esta intervenção começa a ser compartilhada. Mas mesmo assim, não estamos falando em uma mudança na sociedade inteira, porque a sociedade é enorme. Uma sociedade é sempre composta de muitos 
grupos culturais, e esses grupos também estão sempre em mudança. Então, não se trata apenas de "inventar" algo, mas de inventar algo que possa ser compartilhado, que seja espontâneo e se desenvolva, que se abra para colaborações e que permita que as pessoas se tornem parte de um movimento. Penso que para um artista-ativista, e mesmo para qualquer ativista, esta é uma questão fundamental. E recentemente se tornou "a" questão fundamental, porque no passado havia uma cultura esquerdista que estava estabelecida e que permitia que as pessoas compartilhassem muitas coisas e atitudes, maneiras de ser, e que tinha um discurso e uma dimensão científica. Mas estas antigas ideias esquerdistas começaram a entrar em declínio depois de 68. No Brasil há uma história rica, eu não tenho certeza de quando o PT começou, mas já existe por um longo tempo, e isto representa uma nova cultura política, mais plural, mais orientada pelos movimentos, com diferentes ideias sobre organização e também diferentes ideias sobre gestos artísticos que constituem a base da solidariedade. Por todo o mundo isto mudou desde 68 , mas talvez a primeira vez que pudemos olhar para essas novas culturas acontecendo foi recentemente, nos últimos dez, quinze anos.

\section{Como o conceito de "fantasmas coletivos" se relaciona com isso?}

Os "fantasmas coletivos" são uma estratégia específica que as pessoas usaram e ainda usam, e é uma espécie de prisma através do qual se pode ver claramente o que está por trás desta estratégia, além desta estratégia. O conceito vem dos italianos, do Wu Ming, ou do projeto anterior, Luther Blissett. Eles trabalhavam usando um nome coletivo. A questão sobre multiplicidade é muito importante: como criar cultura sem líderes? Como criar arte sem autores? O nome múltiplo é um grande recurso artístico-cultural que permite que as pessoas se apropriem de um movimento e coloquem o seu próprio conteúdo, sua própria vontade, sua própria energia, seu próprio desejo. Mas também é uma metáfora de um processo maior, que vai além das situações em que há um nome múltiplo. É neste sentido que eu uso o conceito "fantasma coletivo", porque é como se algo se levantasse dos mortos. A antiga esquerda estava morrendo, de fato, e se quiséssemos ter algum movimento de justiça social no mundo teríamos de ter uma nova esquerda que não fosse restrita como a Nova Esquerda dos EUA nos 
anos 60, mas ampla, uma esquerda capaz de se adaptar às transformações culturais dos últimos 30 anos, e isso foi trazido por 68 e pela autonomia que as pessoas conquistaram através da cooperação num movimento político.

Você fala de "representação direta" como uma mediação entre "ação direta" $e$ "representação". Nos movimentos parece haver esta oposição entre os que optam por ações diretas e os que optam por ações simbólicas. Gostaria que você falasse um pouco sobre este conceito mediador.

Eu creio que a urgência da ação direta é positiva. A ação direta diz "nós não estamos esperando por uma mudança, queremos fazer a mudança, queremos realizar esta mudança no presente". Isso quer dizer que você organiza situações em que a ação coletiva pode realmente fazer diferença concreta no desdobramento de algum evento. Isso frequentemente tem a ver com os processo políticos em que normalmente não se teria uma participação democrática, que deveriam ser fechados, administrados por executivos. Contudo, eu acho que hoje em dia a ação direta pode se tornar simbólica, porque a insistência das pessoas em mudanças concretas é, em si mesma, paradoxalmente, simbólica. Reivindica as mudanças concretas que não tem acontecido, reivindica a possibilidade de realizá-las. Pode reivindicar o direito de ocupar uma casa ou protestar contra a lei, várias outras coisas que podem inspirar a seguir esta ação em outros lugares, sempre tem um eco na mídia. O que é interessante na diretividade é que ela rompe essa dimensão midiática, que, em primeiro lugar, está cheia de mentiras; em segundo lugar, mal-interpreta; e em terceiro lugar é sempre uma representação, sempre toma a voz daqueles que estão envolvidos em primeiro grau e a substitui pela voz da mídia. Mas a representação direta tem sido uma intrusão na mídia. Está forçando uma abertura na mídia. Isso acontece por três razões: porque a ação direta é bem sucedida, porque ela é percebida como legítima, e também acontece pela surpresa (o que gera curiosidade e novidade suficiente para os jornalistas). Tudo isso torna a representação direta possível. É como os movimentos sociais, eles acontecem em momentos de possibilidade. Movimentos sociais não são sempre possíveis, eles só são possíveis em tempos específicos. Não há sempre a ocasião. 
E você acha que há um conflito entre isso e as ideias situacionistas? Porque quando se vê o espetáculo como totalizante, tudo pode ser incorporado pelo poder do capitalismo global, o que é uma maneira muita negativa de se lidar com as representações. Como você acha que a ideia de representação direta conflita com isso?

Eu acho que conflita claramente com a consequência extrema do anúncio situacionista da sociedade do espetáculo, que só te dá duas opções: você pode ser invisível, e escapar do poder; ou você pode destruí-lo. Eu não acho que estas opções sejam muito satisfatórias ou realistas. Eu acho que o situacionismo é bom por gerar uma quebra. Acima de tudo, dentro das pessoas, dentro dos grupos, na crença do espetáculo. E essa quebra é muito importante para as pessoas. Porque se não se questionar radicalmente o que a mídia diz, sua cabeça e seus atos serão direcionados pelo consenso que aparece na mídia. Mas as pessoas que vivem em sociedade no presente são necessariamente esquizofrênicas. Uma verdade não cobre o todo, e as pessoas que se aferram à análise situacionista começam a viver em uma ilusão, porque vivem num perpétuo estado de guerrilha. Isso começou a produzir efeitos impressionantes. Algumas vezes, aqui em Paris, coisas incríveis acontecem nos movimentos sociais. Atos de descrença, de ruptura, de desnormalização, e então as pessoas que fizeram isso parecem desaparecer quando o movimento social acaba. Eu acho interessante, não sou totalmente contra isso. Mas acho que não é a coisa mais importante a fazer. A outra coisa que isso [a postura situacionista] faz é marginalizar para sempre. Os fatos parecem mostrar que o número de pessoas que adotaram aquela análise é realmente pequeno. Então, ainda que suas ideias sejam bastante interessantes, não parecem capazes de alcançar uma mudança na sociedade, se mantém uma filosofia do desespero. E no entanto, o desespero é muito fácil de encontrar hoje em dia.

Há o ativismo artístico e a arte ativista. Algumas vezes estes conceitos se confundem, outras não. Pensando no que Benjamin disse sobre o fascismo ser a estetização da política, como você vê a relação entre arte e ativismo? 
Benjamin disse que o fascismo é a estetização da política, e que deveríamos então politizar a arte. A grande questão é saber o que significa politizar a arte. Há uma longa tradição do que as pessoas tendem a chamar de "arte política". Isso pode ser muito bem exemplificado por alguns pintores como Leon Golub, um grande artista político dos EUA. Ele morreu recentemente. Ele fazia uma pintura de uma situação que o impressionasse, colocava a paixão de sua própria consciência, e também os sentimentos e a consciência das pessoas que ele testemunhava ou com quem ele colaborava. Ele colocava isso em pintura como expressão. Você vai ao museu e pode ver a pintura. Você pode se sentir chocado por ela, e a questão "o que fazer?" fica por sua conta. Isso é a arte política. O ativismo artístico é diferente. Ele acontece ao mesmo tempo que uma ação direta, como parte de um processo organizacional cuja finalidade não é criar arte, mas realizar um gesto em público, e a arte está na maneira pela qual este gesto vai aparecer. Esta aparência é dupla: para as pessoas que o fazem e para as pessoas que o vêem, ou pelas pessoas que são confrontadas com ele. Esta duplicidade é importante porque o processo de feitura do gesto é o processo da ação política, a maneira de se fazer o gesto é a cultura da ação política. E a existência desta cultura é o que faz desta ação política um continuum, não somente uma ação, mas uma cultura de ações. Então a parte interna do processo artístico neste caso é muito importante. Pode ser mais importante do que todo o resto. E há a parte externa, a maneira com que aparece para aqueles que estão sendo confrontados ou para os terceiros que são um público neutro, pessoas que não decidiram em que lado da linha estão. Para os confrontados, esta arte pode ser uma espécie de arma. Pode ser a arma da surpresa, do espanto, do inesperado, do desconhecido, o que vai fazer com que não saibam como lidar com aquilo. E isso abre um tempo. Um tempo antes que eles decidam como lidar com aquilo. E esta janela de tempo acontece com frequência. A segunda coisa é o significado, que acaba às vezes ficando mais próxima da arte política, com a diferença de que o que você vê não é um autor, não é Leon Golub, ou Pablo Picasso. Você vê um monte de gente, fazendo algo estranho mas que tem uma dimensão estética, pode agradar, ou surpreender, ou ser patético, cheio de pathos, cheio de paixão. Pode ser um sinal de solidariedade, um sinal de sofrimento, e assim por diante. Então há estas dimensões no 
processo do ativismo artístico, que é muito diferente de uma obra de arte política. Arte pode ser um monte de coisas. Não quero dizer que arte seja isto ou aquilo. Eu gosto de arte política, não tenho nenhum problema com ela. É inútil dizer isto é arte e aquilo não é, porque daí falta algo, falta o pano de fundo em que a sociedade está, uma tremenda quantidade de inovação e invenção acontecendo, novas formas de sociedades sendo inventadas. E isso falta às pessoas. Porque as pessoas seguem pensando em termos de "arte política": tem que haver arte acima de tudo, o que interessa é a arte, se alguém se envolve com arte deve somente ter interesse nisso. Isso é feito como um policiamento, para evitar que pessoas e recursos sociais sejam investidos em outros modos de ver a arte.

Você trabalhou com o coletivo Bureau d'Etudes, em Paris. Como foi a articulação entre projeto político (ou projeto ativista) e projeto artístico nesse coletivo?

Eu trabalhei com eles, mas não sou um membro do coletivo, isso deve ficar claro. Durante a nossa colaboração, a maior parte do que eu fiz tinha a ver com o "movimento de movimentos". Foram coisa feitas para eventos específicos, para a campanha do No Border, para o Fórum Social Europeu, e, de maneira mais geral, para pessoas envolvidas com ativismo, aqui na Europa e em outros lugares.

O que o Bureau d'Etudes faz é uma análise, uma "forma" e uma espécie de propaganda. Eles fazem materiais em grande tiragem e distribuem. Milhares de cópias. A ideia é mesmo a de distribuir em contextos políticos, frequentemente dentro das manifestações. A sociedade contemporânea é complexa, é necessária uma análise que possa ser apresentada no formato de um mapa. Não sabemos pra onde estamos indo, quem são nossos vizinhos, qual é a hierarquia, quem controla, quem produz as ideias, quem as distribui e por que, quando, onde, todas essas questões são questões de mapeamento. Ao mesmo tempo, isto já está feito na universidade. Já existe. O conhecimento está em toda parte, no entanto está invisível. É impossível de ser acessado por pessoas comuns. Para isso você precisa do papel tradicional do mediador intelectual. Hoje esse papel é ocupado pelos artistas porque é necessária uma forma que seja reconhecível. Este conhecimento não tem sido 
direcionado apenas para pessoas com capacidade profissional ou acadêmica, mas tem sido direcionado através de experimentação social. Isto é o que queríamos, e é o que eu quero com todo o meu trabalho: que se torne acessível para pessoas engajadas com experimentação social. A maneira com a qual eu colaborava com o Bureau d'Etudes era a mineração de dados de várias fontes. É isso o que eu faço com os artistas com quem colaboro. Recolho fatos, ideias e padrões e então nós os convertemos em forma, com metáforas, com uma distribuição gratuita. Sempre com uma orientação política, não há a máscara de neutralidade que a pesquisa acadêmica e científica sempre veste. O que eu quero produzir é um questionamento, uma experimentação e uma intervenção, estas três coisas. A partir daí as formas são particulares. Com o Bureau d'Etudes tomava a forma de um mapa que podia ser distribuído, com a minha escrita toma a forma de um texto que pode circular livremente na internet e um conjunto de metáforas que transborda as informações e as situações com as quais está envolvido.

Você menciona um papel ambíguo das novas tecnologias. Por um lado, pode gerar um espaço de representação muito positivo, pode ser uma representação "de baixo pra cima". Mas, por outro lado, há uma rede de vigilância muito poderosa. Há uma afirmação muito boa no seu livro, que é "com as tecnologias de hoje a democracia está garantida por princípios darwinistas", acho que está relacionada a isso. Como você acha que a cultura de rede expressa esta ambiguidade?

Quando as tecnologias de rede começaram a ter penetração massiva na esfera social em meados dos anos 90, a primeira coisa que fiz foi escrever uma crítica muito séria a respeito. É um texto chamado "The Flexible Personality" [“A Personalidade Flexível”], que foi lido por bastante gente, foi traduzido para dez línguas. É uma crítica negativa, franca. Tenta mostrar a existência de um novo tipo normativo de personagem ou de personalidade que eu chamo de personalidade flexível. É a descrição de uma pessoa que é controlada. Ou como nós somos quando somos controlados. Nós somos disponíveis para signos que solicitam de nós nossa energia, nossa cooperação, nossa interação com o fluxo de signos. Quando 
Deleuze fala de modulação, é um termo técnico que se refere a uma onda, e é similar à personalidade flexível. Primeiramente, prestar atenção a esse fluxo de signos, e em segundo lugar, que outra pessoa preste atenção ao fluxo de signos que você está emitindo. Não é somente fascinação, porque a interatividade é muito mais proativa do que a fascinação. Nós vivemos numa sociedade que demanda que sejamos ativos. É uma sociedade de ativação. E é por isso que a interatividade se tornou central para esta sociedade, porque todo o novo discurso liberal trata de ativar a energia das pessoas, alcançar recursos humanos desconhecidos, fundamentalmente trata-se de integrar pessoas em um padrão produtivo. Ao mesmo tempo, essas tecnologias de rede são perfeitas para vigilância: elas medem o que as pessoas estão fazendo, localizam-nas, e as proíbem de qualquer atividade considerada ilegal. Depois do onze de setembro nós temos visto um tremendo aumento desta vigilância.

Depois desse primeiro texto crítico eu escrevi todos os ensaios que estão no livro "Unleashing the Collective Phantoms" e colaborei com diversos artistas e movimentos sociais para tentar explorar as ambiguidades destas tecnologias. Porque senão você pode criticar a sociedade de rede e tentar viver em outro lugar. Mas onde este lugar seria? Não sabemos. Teríamos de ir para as montanhas. É muito mais interessante trabalhar com a ambiguidade e desenvolvê-la. Esta era a ideia no final do texto "The Flexible Personality", que realmente se endereçava a pessoas da sociedade do conhecimento e dizia "Vocês podem se apropriar das ferramentas do capitalismo cognitivo e usá-las criticamente, autonomamente, em movimentos sociais, com ações comunicativas", eu sugeria um "ativismo comunicativo". As coisas que eu escrevi nos pontos altos do movimento anti-globalização foram essas.

A partir da reeleição do Bush, e a partir do último ensaio de "Unleashing”, eu voltei a escritos mais críticos e experimentações em pequena escala, geralmente mais artísticas. Acho que os limites dessa ambiguidade foram mais ou menos alcançados, nós já sabemos o que as tecnologias podem fazer agora. E a sociedade de controle também sabe. Não há mais nenhum fator de surpresa aí. A própria normalização do protesto mostra isso: as reuniões anuais com os protestos anuais. Isso quer dizer que não significa mais nada, é só o usual. E isso coincide com a intensificação da vigilância e com a ilegalização da atividade de protesto. Neste contexto, acho que é importante olhar mais precisamente para as novidades que vieram das 
novas tecnologias e da transnacionalização do capital, que aconteceram nos anos 90 e no começo desta década e perceber que tipo de sistema está se formando. É um sistema duro. O que parece agora é que a fase de endurecimento já acabou. Porque agora já há problemas com este sistema duro. Agora talvez seja possível criticá-lo novamente, mas de maneiras diferentes. O movimento antiglobalização aconteceu no meio de uma utopia, o neoliberalismo. Esta utopia deixou muita gente alienada, alguns optaram pela utopia anarquista, que é uma espécie de extremismo de esquerda do neoliberalismo, ainda que os anarquistas não gostem dessa opinião.

Agora estamos em uma outra situação. A crise apareceu claramente, os sistemas políticos são obrigados a responder à crise, e não podem fazê-lo com as respostas neoliberais, porque elas acabaram. A ideia de que você pode especular o dinheiro indefinidamente foi à bancarrota. A ideia de que você pode aplicar força militar para criar liberdade para as pessoas está acabada. Acho que vamos entram num mundo diferente e precisamos saber como este mundo vai ser. Após fazer esta pesquisa eu espero ter a possibilidade de trabalhar com novos movimentos sociais.

Gostaria de fazer uma pergunta a respeito da história deste movimento. Parece ter havido uma "era dourada" entre 98 e 2001, ou 2004, dependendo da análise, e agora um declínio. Como você analisa a "onda” do movimento a partir de 94?

Eu acho que é muito difícil de dizer quando isso tudo começa. É uma convenção começar com os zapatistas, porque é quando este movimento ganha um rosto (ou uma máscara). Nos Estados Unidos e na Europa começa a ficar realmente importante em 98. Porque a Ação Global dos Povos foi fundada, houve o primeiro contra-encontro durante a reunião da OMC, e contra o G8 na Inglaterra, com o Reclaim the Streets, que foi grande, e em 18 de junho do ano seguinte foi muito grande. Esse foi o padrão. 18 de junho foi o modelo pra todo o resto. E penso que tudo culminou em 15 de fevereiro de 2003, porque foi quando aconteceu a maior marcha de protesto da história do mundo, contra a Guerra do Iraque. E a organização era parecida. O modelo se desenvolveu até aí. E mesmo assim não parou a 
guerra, o que fez as pessoas perceberem que os movimentos que não se endereçavam a uma instância precisa de poder não atingiriam seus objetivos. Não mudariam a vida, que é a premissa de movimentos sociais, mudar a vida. Houve um colapso. Mas sem apagar as conquistas ou acabar com os movimentos, porque várias coisas continuaram. Quem diz que as coisas pararam está errado, elas ainda continuam. Mas elas não estão mais crescendo. Elas cresceram tremendamente e então encolheram tremendamente depois do 15 de fevereiro. Movimentos sociais são altamente visíveis quando crescem. Ninguém sabe a próxima vez que isto vai acontecer, mas sempre acontece de novo. É só aguardar pra ver. Há duas maneiras de aguardar: esperando que as coisas aconteçam da mesma maneira novamente ou sabendo que quando acontecer de novo será diferente. Pessoalmente, eu escolho a segunda opção. Acho que vamos responder a novos problemas, usando novas linguagens, e vamos ter aprendido não só com o que fizemos, mas com o que a sociedade fez para se renormalizar, para parar esta dinâmica imprevisível. Para isso, novos gestos vão ser importantes, e é aí que a performance entra. Porque movimentos sociais tratam de gestos. Gestos feitos com os corpos, palavras nos gestos. Há uma diferença do teatro propriamente dito. Nestes gestos de que falo não há moldura ficcional, eles reclamam a realidade, e ainda assim eles atuam, como gestos e palavras. Quando você os vir vai reconhecê-los, porque todo mundo os conhece. E essa é a coisa pela qual lutar, para criar estes gestos, para recriá-los. É disso de que a cultura política é feita.

(Entrevista realizada em Paris, no dia 10/11/2008) 


\section{EXTRATOS DO MANUAL PRÁTICO DE DELINQUÊNCIA JUVENIL}

\section{A Gurizada Big Mac Feliz}

(ataque oito)

Achar cento e cinquenta reais na rua não é para qualquer um. Quinhentos mil tipos de eventos devem ser sincronizados, acasos dos mais absurdos, para que a grana venha parar no seu bolso. Nós fomos os sorteados da vez neste Fantástico Evento Cósmico. Um Gigantesco Globo cheio de bolinhas numeradas e saiu justamente o nosso número. Coisa de louco. Tivemos discussões monstruosas pra decidir o que fazer com a grana. Todos concordavam que a grana era de todos, ia ter que sair um consenso de um jeito ou de outro.

Nem estávamos falando sobre isso quando surgiu a ideia. Jean estava contando do dia em que sua moto estragou perto da Vila zumbi e ele saiu em busca de ajuda e se sentiu cabreiro no meio de uma ambiente estranho. Foi na cabeça do Vinicius que acendeu a lâmpada.

- A gente pode usar a grana pra gerar uma situação inversa a essa do Jean.

- Situação inversa.

- Lembra aquela que os caras do MST foram num shopping e os lojistas fechavam as portas de medo? Não lembro nem se isso aconteceu mesmo ou eu sonhei. Pois é, a gente pode fazer parecido. Façam as contas: com cento e cinquenta reais dá comprar vinte McLanche Feliz!

- McLanche Feliz? Vai dar a grana pro Império agora, é?

- Ativista de butique é foda!

- Calma, rapaziada estressada! É só a gente fazer as coisas de um jeito que pagariam o triplo para que não gastássemos a grana lá.

- Conclua o plano, por favor, conclua. - Falou o Fabio coçando a barba rala.

- Convidamos vinte piás de rua pra fazer um lanche numa praça de alimentação de algum shopping.

- Rapaz... 
- O que vocês acham?

Não tínhamos muito o que falar: era um plano simpático. Todos ficaram quietos e cada um, mergulhado em seus pensamentos, foi sendo seduzido aos poucos pela ideia.

Não seria difícil encontrar a gurizada ideal. Sempre vagabundeamos muito pelas ruas da cidade e conhecíamos muitas figuraças da delinquência infantil. Eu mesmo conheço uns quantos e quanto mais pensava nas possibilidades mais ficava animado com a ação.

A ação foi marcada para um sábado à tarde, momento mais ou menos tradicional para compras. Famílias inteiras passeando pelo Paraíso do Consumismo. Iríamos relembrá-los do custo social daquele conforto e daquele ar-condicionado central em meio ao frio do inverno curitibano.

Começamos nosso recrutamento perto das onze da manhã na Boca Maldita. Eu conhecia um polaquinho que dava beijos no rosto das pessoas antes de pedir moedas, mais duas menininhas, entre 4 e 5 anos que vendiam chicletes.

Meio dia já estávamos com o time completo. Um autêntica turminha do capeta. A aparência de nossa multidãozinha era tal que ninguém ficava no mesmo lado da quadra que nós. Fábio e Jean arrumaram uns cheiradores de cola e Vinicius ficava tentando explicá-los que se eles cheirassem antes do lanche não iam sentir fome.

- Sério tio? Se tú não fala nóis não sabe.

- Fica sossegado aí!

Tinha uns que ficaram amigos mesmo e enquanto íamos ao Shopping Müller começaram a contar histórias de como eles se viravam e como roubavam as paradas e que fome não passavam. Eram uns autênticos caçadorzinhos.

- E como é que vocês se escondem?

- É! Onde é que vocês dormem, pra onde é que vocês fojem quando o bicho pega?

Então nos mostraram uns lugares incríveis. Autênticos pontos que o mapa não cobre. O mapa não é o território. Lugares nos miolos dos quarteirões. Banheiros de fundos abandonados, depósitos esquecidos e pasme, até uma capelinha nos fundos de um troço que um dia foi uma mansão.

Fora os esgotos e os tuneis secretos. Em resumo: os guris eram feras. Chegando no 
Müller logo quebramos a cara. Um moreno muito bem engravatado, logo na entrada, cortou nossos embalos. Na hora que ele viu aquela maloqueiragezinha reunida disse não. Nem discutímos, apesar dos protestos do Panfletário Vinicius, afinal tínhamos ainda o Curitiba e o Plaza pela frente. É, curitiba tem três opções de shopping pra você viver seu consumismo e escolher quem te enraba.

Quando estávamos indo para o Shopping Curitiba o passeio começou a ficar mais divertido. A gurizada começou a se soltar mais e os transeuntes realmente se impressionavam e se preocupavam com a cena. Mulherada protejendo as bolsas, boas pintas escondendo os celulares. foda foi controlar os cheiradorzinhos. Os piás eram muito fodas mesmo, por mais que Vinicius cuidasse sempre davam um jeito. Você se distraía e lá vinha um com a boca mole.

- Ôooo tio! Cêeee é gent-te boa, viu?

Mas eram todos grandes personalidades, isso eu garanto. Era só trocar umas idéias com qualquer um deles e suargia uma história de Coragem, Resistência \& Luta. Alguns equívocos, talvez muitos, mas eram sem dúvida histórias de Coragem, Resistência \& Luta.

No Shopping Curitiba foi as crianças que queimaram o filme. Foi dobrar a esquina na chegada e começaram a gritar feito uns doentes. Quando começamos a subir a escadaria da entrada o segurança já veio em nossa direção fazendo sinal que não. Mandamos à merda e descemos a Sete de Setembro em direção ao Plaza Shoping. Lá foi nosso triunfo, lá conseguimos entrar. Eles estão em obras e foi bem mais fácil depistar os seguranças. Também porque aperfeiçoamos nosso método: dois por vez.

Na praça de alimentação o espetáculo foi grandioso. Foi cômico ver os casaizinhos Mauricio/Patricia trocando de mesa por causa do cheiro das crianças de rua. As mães com filhinhos bem vestidos saíam da fila do McDonald's e procuravam outra lanchonete. Vinicius ganhou mais uma: realmente a cada um lanche que vendiam pras nossas crianças deixavam de vender outros três por causa das pessoas que saíam fora com medo.

Os funcionários da lanchonete também tiveram seu calvário porque armamos a palhaçada com requintes de crueldade, cada menino tinha sua grana contadinha para o seu McLanche Feliz. E muitos deles nem sabia pedir direito a bagaça. 
Foi muito divertido. Acompanhávamos a cena de longe, observando a galerinha e os sete seguranças especialmente designados para garantir a ordem e manter a segurança do resto do shoping inteiro devido à preocupante presença de nossas crianças. E eram crianças mesmo, posso garantir que todos tinham menos de dez anos.

Já estávamos em clima de comemoração enquanto eles terminavam seus sanduíches quando vimos que ainda teria muito rolo pela frente. "Com a barriga mais cheia começei a pensar, que eu desorganizando posso me organizar." Mais ou menos nesse estilo o negóçio. A gurizada se repartiu numa euforia incontrolável. Uns foram pra uma loja de brinquedos no segundo andar. Outros nem pensaram duas vezes e foram para os jogos eletrônicos. Pra completar tinha os que entravam nas lojas mexendo em tudo. Um caos.

Não podíamos deixá-los ali. Éramos os responsáveis. Nossa paternidade começou quando achamos aquela grana no chão. Não podíamos negar a responsa. Nos dividimos e cada um ficou com um grupinho. Fui atrás dos que foram na loja de brinquedos.

Foi entrar na loja que já vi o tamanho da encrenca. Tinha um pirralhinho que não deveria ter mais que quatro anos que tinha sentado numa moto à pilha ou à sei lá o que fazia uma zoada do caralho. A funcionária só perguntava desesperada quem eram os pais da criaturinha. Tinha ainda os outros três que derrubavam tudo que era bonequinho que tinha nos mostruérios.

Corriam com os bonequinho e se escondiam atrás das prateleiras. Uma cliente da loja nem disfarçou o seu preconceito e saiu com seus filhos da loja, sob seus protestos, pois estavam se divertindo com a bagunça. Meus meninos estavam felizes. Alheios à discriminação, felizes por serem o que estavam sendo e nada mais. Uma funcionária se aproximou e perguntou se eu desejava algo. Falei que estávamos olhando pra ver se encontrávamos algo interessante. Na porta da loja dois seguranças babando de vontade de terminar com aquela zona assim que o gerente desse o sinal.

Se contar o resto da gurizada aos cuidados dos outro e os que tinham cheirado cola e tal e deviam estar doidões, acho que a direção do shopping teve que chamar reforços para a segurança. Segurei eles na loja o máximo que pude e quando os ânimos se acalmaram um pouco convoquei a turma pra sair fora. 
- Seguinte galera! Temos que sair pra encontrar os outros!

- Aonde?

- Na pracinha lá na frente.

$-\mathrm{Ahhh} . .$.

Saímos e quando chegamos já tinha um monte de gente esperando. Achei que tinha tido trabalho com os moleques, mas o Jean contou que os deles foram expulsos dos jogos eletrônicos por cheirarem cola. E isso nem foi o pior, jogaram um monte com três cartões roubados que o Jean nem viu como conseguiram. digamos que tratava-se de especialistas mirins, mão de obra qualificada.

Esperamos chegar o resto e quando vimos que ninguém mais viria \& o sol estava se pondo \& o frio chegando com a noite Fabio puxou de sua mochila uma caixa com seis rojões.

- Façam um fogueira! Será o São João dos excluídos!!

Fizemos uma fogueira meio mandrake e quando as chamas estavam bem altas a ponto de chamar a atenção dos desavisados ou da polícia soltamos os rojões.

Todos gritaram \& pularam \& dançaram em volta da fogueirinha ou de alegria ou de frio. Vivemos ali, por segundos que tenham sido, uma Zona Libertada.

\section{A Madame, Os Poodles, A Cegueira \& O Castigo}

(ataque vinte e seis)

O problema da burguesia não é o fedor. O problema da burguesia nem é a ânsia de riqueza. $\mathrm{O}$ que irrita na burguesia é a ostentação. $\mathrm{O}$ que me trinca o saco é que mesmo com a miséria que é suas vidas, iludem-se que são superiores e o pior, não desperdiçam uma única oportunidade de exercitar essa ilusão de superioridade.

Essa semana a dança do acaso me colocou diante duma situação dessas. Estava trabalhando, numas carreiras pra entregar uns documentos, almoçar e voltar pro trampo, pelas bandas do Batel. Então cruzei com uma mendiga. Odeio rótulos, chama-la de mendiga é 
matar a descrição. Era uma senhora com três crianças, todas com menos de cinco anos, uma no colo, uma que recém aprendeu a falar que alcançava as coisas e a maiorzinha espertinha, que ajudava a mãe a catar lixo. Eram três menininhas e as três choravam. A iniciante na linguagem não tinha como esconder a sinceridade!

- Eu tô com fome!

Tive que reduzir o passo com aquilo tudo e então acabei vendo o que preferiria não ter visto. Vi sair pelo portão a dona da casa, madame padrão, a descrição dela deve ser o que aparece no Aurélio quando se procura por isso, com dois quilos de cosméticos e não-sei-quelás no rosto e dois poodles. Odeio poodles. Nada contra animais. Admiro todos que defendem os direitos dos animais e todo mais, mas odeio poodles.

Com as crianças chorando e meio que sem saber o que fazer a senhora perguntou se a madame tinha alguma moeda.

- A senhora tem alguma prata pra me ajudar minha senhora?

Então a madame faz o infazível, ignora a mãe de três filhos e segue com seus poodles. Ignorou por completo. A mamãe olhou pra mim e sei lá se foi o fato de eu ter parado quando vi aquilo ou não, o que sei dizer é que ela teve um acesso de indignação, correu até a frente da madame e perguntou:

- Ôu! Eu estou aqui?! Não está me vendo não?

E não é que filha da puta continuou com sua cegueira? Nem os poodles deram bola. Aquilo me emputeçeu de uma maneira que nem que eu contasse até mil conseguiria me conformar. Intimei ela.

- A senhora está precisando de alguma coisa?

- Olha moço, o que o senhor puder ajudar...

Só tinha um ticket-refeição pra almoçar no centro, um vale-transporte e uns centavinhos que não fariam a menor diferença. Foda-se o almoço, apresentei o ticket. Foi massa. Deu pra ver o brilho nos olhos dela.

- Muito obrigado, seu moço! Deus te abençoe! O senhor não sabe como é difícil. Tá vendo essa rua toda? Os lixos tão tudo cadeados.

Na mão ela tinha uma sacolinha de supermercado com alguns restos de comida. 
- O que a senhora tem aí?

- Frango assado. Tava tudo aí no lixo da casa dessa senhora dos cachorros. O resto dos lixos tavam todos chaveados.

Peguei aqueles restos de frango e depois de esperar a senhora ir embora almoçar com suas crianças olhei pra casa da madame dos poodles. Tinha uma janela aberta do lado esquerdo. Analisei a distância e concluí que era possível. Peguei cocha por cocha, osso por osso dos restos de frango e mandei ver na janela. Já estava terminando quando ouvi alguém gritar no outro lado da rua e tive que saír correndo.

Não consegui engolir essa história direito. À noite contei pros piás na kitnete e não teve um que não ficasse revoltado. Vinicius se exaltava em sua fúria.

- Cara, precisamos matar essa velha!

- Uma morte lenta e dolorosa...

- É! Fazer picadinho de seus cachorros e fazê-la comer tudo, matar a lazarenta de overdose de poodles.

Jean foi o único a ficar quieto, com um estranho brilho no olhar.

- Já sei o que fazer.

- O quê, seu monstro?

- Vamos invadir a casa daquela filha de uma puta.

- Invadir? Mas é uma mansão brô, deve ter quinhentos tipos de alarmes e proteções.

- Calma! Nós não precisamos fazer as coisas na louca, de qualquer jeito.

- E o que Vossa Delinqüência sugere?

- A gente pega nossos uniformes de gari e finge estar trabalhando no quarteirão da casa pra analisar com calma todas as possibilidades de entrar lá.

Uma excelente idéia. Cada vez mais me convenço de que aqueles uniformes com logotipo da Prefeitura Municipal de Curitiba foram uma grande sacada. Os desempregados Fábio, Vinícius \& Sérgio foram convocados para a missão, durante a semana à tarde. Quartafeira eu estava nas masmorras de meu trabalho quando Fábio me liga entusiasmado.

- Ari do céu! Você não bota fé!! A velha tem uma empregada muito gostosa.

- Tá, mas e daí? 
- Daí que Sérgio escreveu uns hai-kais apaixonados, entreguei a ela quando estava indo na padaria buscar o café da tarde pra patroa e ganhei a gata.

- Ganhou a gata??

- Só! Vamos sair tomar umas beras hoje à noite.

Não podia ser mais perfeito. Fábio descolou informações importantíssimas. A velha é viuva, tomas uma boletas pra dormir e desmaia na cama e nenhuma empregada agüentou trabalhar lá por mais de seis meses, tamanha a Mesquinhez \& Arrogância da patroa. Saí do trampo na quarta crente que faríamos a invasão de noite. Fabro porém, pediu mais um dia para os preparativos \& as investigações.

- Milene me falou que amanhã à tarde a patroa vai sair e me convidou para ir até lá.

- Dentro da casa? Sério?

- Bem isso mesmo, se pedíssemos a deus e fossemos atendidos não seria tão perfeito.

Traçamos então o mais perfeito plano de invasão de nossas carreira. Pelo menos era o que achávamos. Não que tivéssemos grandes facilidades, afinal todas as janelas e portas tinham grades, mas pelo menos tínhamos um "mapa" do território, sabíamos que não tinha alarme e ainda contaríamos com as instruções de Fábio, o especialista mor em definição de alvos.

Esperamos a meia noite e saímos a pé e em silêncio: Momentos de Concentração. Jogamos todo o material que utilizaríamos na mochila que Vini levava nas costas e seguimos Firmes \& Confiantes. Sabíamos que a tarefa não seria nada fácil. O muro que tínhamos que pular ficava numa avenida movimentadíssima, mesmo de madrugada, e tivemos que nos separar uma quadra antes. Foi um por vez pular o muro, uma coisa estressante pra quem fica por último, como foi o meu caso. Saber que as possibilidades de alguém se ligar na parada depois de quatro neguinhos pularem o mesmo muro são altas é foda. Quando saltei vi que se tratava do quintal do único estabelecimento comercial do quarteirão. E era pequeno e era apenas o interlúdio entre dois grandes problemas.

O primeiro grande problema era atravessar o quintal da casa vizinha. Tudo iluminado, não tinha cachorros, mas a luz era muito forte mesmo. Sujo pra cacete. Colocamos nossas "tocas zapatistas" que guardamos desde a noite dos poemas nas vidraças e fomos um por vez 
de novo. Dessa vez fui o primeiro. Fui também o primeiro a encarar o jardim da megera. Era bonitinho. Mas certamente ordinário. Eu sei que é foda, mas a culpa foi dela e naquele momento a velha era a encarnação do mal. Tínhamos que sacaneá-la. Os piás chegaram logo e Fábio foi logo dando os toques.

- Tão vendo aquele pé de manga ali? Temos que subir nele e saltar em cima do telhado.

Era o grande problema número dois. O único modo de entrar na casa era pelo telhado. Segundo Fábio tinha uma banheiro nos fundo, próximo do quarto da velha que tinha um alçapão que dava acesso ao sótão. Subir a árvore e saltar no telhado foi fácil, emprenho foi soltar as telhas pra entrar. Elas estavam muito bem presas e Jean, depois de demorar a chegar devido a uma misteriosa frase que escreveu com óleo queimado na grama, teve que arrancar um galho da árvore para alavancá-as. Como era de se esperar o sótão tava escuro pra cacete.

Quando acendemos a lanterna notamos que o finado marido era fã do Reader's Digest, caixas e mais caixas da revista, mofadas e em estado de decomposição. O tampão de madeira foi fácil de abrir. Fábio então nos olhou com uma expressão grave.

- Piazada, agora é o momento mais importante. Vocês ficam aqui, eu vou primeiro e checo se as portas dos quartos delas estão fechadas. Se não tiverem tenho que fechar. Depois eu fecho a porta que tem na entrada do corredor dos quartos, se conseguir isso nenhuma das duas vai ouvir os barulhos, se fizermos algum. Aí eu volto e dou o toque pra vocês descerem e lembrem-se: tem dois cachorros no quarto da bruxa, nada de barulho!

Desceu e ficamos no aguardo. Não sei se o tempo se dilata nestas circunstâncias, mas a verdade é que passaram dois séculos até que ele voltasse.

- Foi foda, a porta rangia e levei dez minutos pra fechar cada uma, agora desçam

Com todo o cuidado do Universo descemos e cada um tratou de pegar seu material de ataque. Jean estava morrendo de curiosidade de conhecer a despensa, geladeira e descobrir se tinha alguma adega. Vinícius foi no armário onde estavam as comidas dos poodles e encheu as sacolas de bilhetes com frases chupadas dos comentários de Rogério Coacho no blog dos Delinquentes: "Seus cachorros comem enquanto irmãos passam fome". "Esta comida foi desenvolvida para cachorros de todas as raças mas os donos que pensam como Hitler podem 
consumir sem contra-indicações". "Se não souber ler pergunte a sua arrogante dona". "Coma tudo crianças. Para não sobrar nada aos mendigos que reviram a lixeira". "Esta ração deixa o pêlo macio e o latido mais forte contra os pobres de sua rua."

Fábio ficou de butuca na porta do corredor pra ver se alguma das duas acordava e emitindo constantes pssssius. Eu e Sérgio nos encarregamos do resto. Sérgio colou bigodes e chifres adesivos nos retratos da parede. As paredes era de um azul de tonalidade forte e me desatamos a escrever frases com giz. "Os Mendigos Invisíveis Estiveram Aqui”. "A senhora foi selecionada pra pagar os pecados da burguesia". "Tome cuidado com os Mendigos Invisíveis". "Dinheiro não pode comprar felicidade, mas pobreza não pode comprar nada".

Vinícius acabou primeiro, se juntou a nós e ficamos esperando Jean. Depois de alguns minutos ele apareceu carregando sacolas.

- Vinho, muitos vinhos e queijos, muitos queijos. Teremos festa na saída.

- Maaaassa!

- Calem a boca seus merdas! - Fábio era o mais visivelmente estressado.

Pediu pra darmos um tempo, abriu a porta do corredor e foi escrever com giz na parede diante da porta do quarto da velha: "Não abra seus olhos Dona Jassira, a senhora não ira gostar do que vai ver". Imediatamente tratamos de sair fora, foi bem mais difícil subir de volta no sótão. Encaixamos as telhas de Mal \& Porcamente saímos em fuga desesperada. Não sei porque, mas na hora de fugir a adrenalina sempre dispara. Nessas hora mal se consegue pensar, atravessamos todos juntos o quintal vizinho iluminado e em segundo estávamos na rua, gargalhando de nervosismo. Corremos até uma praça próxima e quando nos jogamos na grama desatamos a rir.

- Cara! Imagina a cara da bruxa quando ver aquilo...

- Foda! Muito foda!!!

Abrimos os vinhos provavelmente caríssimos e devoramos os queijos. Já estava bêbado quando me liguei que nem tínhamos visto o que Jean escreveu com óleo queimado na grama.

- Fala cara, o que era?

- "A senhora não entendeu, mas isso é maravilhoso". 
Quem passasse na rua ao longe provavelmente veria umas das mais loucas cenas desta metrópole, cinco malucos fazendo um pique-nique etílico nos confins da noite.

Realmente, isso é maravilhoso.

\author{
O Nonsense, Meu Nego, No Combate Ao Desemprego \\ (ataque vinte e nove)
}

Era uma vez num programa de entrevistas... Era da Bruna Lombardi? Não lembro... O Maguila, ao ser questionado sobre o que fazia antes de lutar boxe, respondeu que trabalhava como pedreiro. Pra complementar e salientar que não tinha vergonha do seu passado, nosso herói soltou essa pérola.

- O trabalho danifica o homem.

Desde então esta frase ficou estampada na minha mente como uma Profunda Verdade Universal. O trabalho mata a criatividade humana e cria milhões de esquizofrênicos em todo o planeta. Discutíamos isso no Hospital Evangélico na noite anterior à minha alta e ao meu fatal retorno ao trabalho.

Jean discursava sobre a esquizofrenia do homem moderno.

- Saca só, você tem uma montoeira de problemas particulares. De repente você está vivendo um inferno amoroso e no trabalho tem que sorrir a todos os superiores. A gente pode estar numa pior, deprimido e desanimado pra caralho, mas sua produtividade não pode diminuir.

- Se diminuir: pé na bunda!

- Sacaram que somos obrigados a desenvolver duas personalidades?

- Só! As vezes até mais.

- E o que me deixa puto é que essa psicopatia é o padrão normal de conduta. Se um 
caradura invocar de não dividir sua vida em duas partes será ele o louco e o desajeitado.

Aproveitei a oportunidade pra falar de umas viagens que tive em meio a meus delírios de febre.

- Isso sem contar com falta de sentido cada vez maior nos trampos que restam.

Não sou um grande teórico, nunca freqüentei nenhuma academia e a intelectualidade me dá náuseas, mas gosto de arriscar uns palpites e tentar entender, do meu jeito, como as coisas funcionam.

- O capitalismo, pra medir o valor das coisas sempre se baseou no tempo de trabalho gasto na criação das mercadorias.

- Pelas barbas de Karl Marx! Aonde que você quer chegar?

- Acontece que hoje o tempo gasto e zero por conta das automatização e o valor das coisas tornou-se abstrato.

- Continue professor.

A gurizada reunida só sabe mesmo é avacalhar. Tiram onda de tudo feito uns retardados. E na hora de trocar idéias, um sempre discorda do outro, unicamente por esporte. Mas continuei, sem nem saber ao certo como expressar minha idéia .

- Só que tem uma contradição gritante nessa parada toda. A tecnologia dispensa os trabalhadores e sem compradores a máquina não roda. É preciso mercados, muitos mercados, daí privatizarem tudo. Não duvido que ainda vão inventar trabalhos sem sentido só pro capital continuar circulando e o sistema se manter.

- Ari, confesso que isso tá confuso pra caralho.

- E, você esta andando em círculos sem chegar em ponto algum, ainda bem que você não é professor de nada.

"Felizes são aqueles que andam em círculos, pois serão conhecidos como rodas."

Resolvi partir direto pros finalmentes e deixar as teorias mal interpretadas e os conceitos distorcidos de lado.

- Bom galera, durante um delírio de febre vislumbrei um Movimento do Trabalho sem Sentido, alguma coisa do tipo MTS ao invés de MST.

- O que significa isso Ari? 
- A gente pode plagiar as cores e a bandeira do MST pro negocio ficar ainda mais palhaço e criar mesmo o movimento.

- Mas que caralho! Que movimento?

- Por alguns trocados, oferecer vagas pra uns trampos totalmente nonsenses.

- Tá vamos virar empresários, empregadores agora...

- É Ari, o Fábio tem razão. E a grana? E o cacife?

- Calma cambada de pessimistas. Não é um mês de trabalho com carteira assinada seus tongos! São bicos. Bicos Nonsenses \& Cia Ltda.

- Explica melhor, dichava, desmurruga esse bagulho.

- Por exemplo, por cinco pilas contratamos pra cavar um buraco e depois tapá-lo. E depois um outro cava e tapa mais um buraco e por aí vai.

- Que coisa mais ridícula e absurda.

Tenho que admitir que os caras não aceitaram a coisa de imediato. Literalmente tratase de algo saído de uma mente delirante. Por fim a bizarrice da idéia acabou seduzindo o povo.

O problema eram os tais cinco pilas pra pagar os "salários." Passou-se uma semana até que sobre a cabeça de Vinícius que aquela famosa lampadazinha acendeu-se.

- Cara! lembra as idéias daquele doido do Rogério Coaxo do blog dos delinqüentes?

- Só!

- Pois então, aplicamos aquele migué do sobrinho do interfone pra conseguirmos a bufunfa pro MTS do Ari!

O caso foi de um típico meme, pulando de cérebro em cérebro, Mutando-se \& Replicando-se sem nenhuma interferência nossa. Jean \& Fábio surgiram também num plano B. Circulou pela Internet a historia de um neguinho que dá curso de mendicância pregando que é possível levantar duzentos paus se escolher os lugares certos pra mendigar. Marmita, irmão da Milene, namorada do Fábio, se escalou pra tentar cuidar de carros em estacionamento em dia de jogo no Couto Pereira.

Para a operação Interfones, Vinícius voluntariou-se. É uma boa idéia, mas requer toneladas de paciência e muita dedicação. Escolheu um trecho da padre Agostinho com 
bastante prédios e no horário do Jornal Nacional.

Apertava o interfone e falava.

- Tia? Oi tia!

Quando não se tratava de uma mulher com um único sobrinho as pessoas ou perguntavam “o que?," “como?” ou então desligavam o interfone. É uma idéia que requer paciência, eu falei.

Até que lá pelo milionésimo toque a Profecia de Coaxo se concretiza.

- Oi ... É você Marcelo?

Com o sinal verde dado, Vinicius soltou essa que estava com o carro estragado cinco quadras a baixo e que precisava de quarenta reais emprestados.

- Eu te avisei que aquele carro ia te dar problemas e prejuízos. Sobe aí que eu te empresto, mas que isso não se repita, hein? Dê um jeito nessa cangalha veia.

- O carro ficou aberto, tenho que correr lá. Vai subir o Vinícius ai pra pegar, ok?

- Tá bom. É ate melhor. Senão eu ia ter que te dizer muitas verdades.

Deu certo. Ela caiu. Fábio \& Jean ainda conseguiram vinte e cinco pilas. Marmita quebrou a cara no dia do jogo, já existe um cartel explorando os estacionamentos, não conseguiu um único centavo. No total levantamos 65 Dinheiros para estartarmos nosso MTS.

Com o tempo, todos gostaram dessa coisa de brincar de vanguarda.

Nosso movimento é quase artístico. Nosso movimento é quase vanguarda. Se nada disso é verdadeiro, então beleza. Ele no mínimo é QQQ, Quase Qualquer Qoisa.

Fábio conseguiu pás, enxadas, um balde e dois cavaletes na casa de seus coroas em Colombo. A empreitada consistia em cavar um buraco, raso mesmo, pra não dar muito trabalho. Colocar a terra em cima de umas tábuas que colocaríamos sobre os cavaletes. Dar vinte e três voltas em torno do cavalete repetindo o Mantra Sagrado:

"Quem inventou o trabalho não tinha o que fazer."

Depois tapar o buraco, meter a mão nos cinco reais e partir para o abraço.

A definição do local da obra gerou discussões monstruosas. Sérgio \& Vinícius queriam que fosse no centro, um Mega Evento. Fábio queria que fosse perto do viaduto Capanema, nas redondezas da rodoviária de Curitiba. Jean ficou do meu lado e vencemos o debate. 
Continuaremos voando por toda a periferia. Ação de impacto é coisa pra rato de mídia. Estamos fora, não gostamos de aparecer na foto.

Escolhemos o bairro do Cajurú e fomos de ônibus mesmo, com a presença marrrrrcante do figuraço Marmita e com os cavaletes no corredor, dando quinhentas explicações aos curiosos que insistem em existir, graças aos céus, pois são os curiosos que garantem a evolução da espécie.

Chegando no Cajurú escolhemos o lugar mais pop das proximidades, o terreno baldio ao lado do bar do Espedito, tava escrito com"S “ assim mesmo. Montamos os apetrechos e esticamos a enorme faixa que Sérgio preparou.

\section{HÁ VAGAS. SERVICO FÁCIL. DINHEIRO À VISTA.}

Três frases com três palavras mágicas para ressoarem nas mentes de Desempregados, Vagabundos \& Vadios em geral, essas criaturas lindamente românticas do mundo moderno. Não demorou muito pra chamar a atenção dos pinguços do boteco. Mas não foram falar com a gente, mandaram um moleque.

Explicamos para o pirralho e ele voltou rindo sozinho para o bar. Ouvimos gargalhadas e não demorou muito pra pintar o primeiro voluntário. Bêbado e provavelmente duro.

O cara mais se escorava na pá do que cavava propriamente. Devido ao estado de bebedeira do cidadão, o que era pra ser fácil tornou-se difícil. Era tão cômico que acabou se formando uma multidão de curiosos, sempre eles ao redor. Marmita ria tanto que nem participou da ação, sentou-se um pouco distante e ficou se contorcendo.

$\mathrm{Na}$ hora das vinte e três voltas a risada era geral. O povo não botava fé no que estava acontecendo. Não botavam fé mesmo, mas na hora que ele tapou o buraco e pegou as cinco pratas ganhamos respeitabilidade. O negócio era sério além de palhaço.

O segundo funcionário foi o moleque mensageiro que fez tudo rapidinho e saiu feliz da vida pra torrar a grana nos caça-níqueis. Foi uma ação muito divertida e até recompensadora no sentido do reconhecimento pela população local. Não faltaram trabalhadores e todos nos trataram bem.

Os 65 dinheiros acabaram rapidinho, o sucesso da empreitada foi total. Nosso 
movimento é viável e digo uma coisa, do fundo de meu Coração Delinqüente: o dinheiro da mulher que caiu no Migué do Interfone foi muitíssimo bem aplicado. Bem explicadinho acho ela até sentiria orgulho. Temos outras idéias ainda para por em prática. Descobrir um formigueiro e criar o "Sedex 10 Para Formigas", pega a carga de uma delas e entrega na porta de casa, cinco pilas pelo transporte. Ou então localizar todas as bitucas de cigarro de um quarteirão e orientá-las a Meca, bitucas Muçulmanas, saca? Dez reais por isso, pois sabemos que é foda, primeiro achar todas as bitucas, depois descobrir que diabo de lado fica Meca.

Enquanto esperávamos o ônibus no ponto tivemos que responder a um batalhão de perguntas a respeito de quem éramos, o que significava aquilo tudo e onde seria nossa próxima performance.

- Somos do MTS, movimento do trabalho sem sentido e infelizmente não sabemos quando haverão novas vagas. 